VALÉRIA LOPES RODRIGUES

\title{
SISTEMA DE APOIO À GESTÃO URBANA ESTRUTURADO EM \\ SIG: APLICAÇÃO EM JAÚ-SP
}

\begin{abstract}
Tese apresentada à Escola de Engenharia de São Carlos da Universidade de São Paulo, como parte dos requisitos para obtenção do título de Doutora em Ciências, programa de Pós Graduação em Geotecnia.
\end{abstract}

Orientador: Prof. Dr. Oswaldo Augusto Filho 
AUTORIZO A REPRODUÇÃO TOTAL OU PARCIAL DESTE TRABALHO, POR QUALQUER MEIO CONVENCIONAL OU ELETRÔNICO, PARA FINS DE ESTUDO E PESQUISA, DESDE QUE CITADA A FONTE.

$4696 \mathrm{~s}$

Lopes Rodrigues, Valéria

Sistema de Apoio à Gestão Urbana estruturado em SIG: Aplicação em Jaú (SP) / Valéria Lopes Rodrigues; orientador Oswaldo Augusto FIlho. São Carlos, 2013.

Tese (Doutorado) - Programa de Pós-Graduação e Área de Concentração em Geotecnia -- Escola de Engenharia de São Carlos da Universidade de São Paulo, 2013.

1. Gestão urbana. 2. Planejamento territorial. 3. SIG. 4. Sistema customizado. 5. base de dados integrada. 6. Jaú (SP). I. Título. 


\section{FOLHA DE JULGAMENTO}

Candidata: Engenheira VALERIA LOPES RODRIGUES.

Título da Tese: "Sistema de apoio à gestão urbana estruturado em SIG: aplicação em Jaú-SP".

Data da defesa: 23/07/2013

\section{Comissão Julgadora:}

Prof. Dr. Oswaldo Augusto Filho (Orientador)

(Escola de Engenharia de São Carlos/EESC)

Prof. Dr. Reinaldo Lorandi

(Universidade Federal de São Carlos/UFSCar)

Prof. Dr. José Augusto de Lollo

(Universidade Estadual Paulista "Júlio de Mesquita Filho"/UNESP — Ilha Solteira)

Prof. Dr. Leandro Eugenio Silva Cerri

(Universidade Estadual Paulista "Júlio de Mesquita Filho"/UNESP - Rio Claro)

Prof. Dr. Sérgio Antonio Röhm

(Universidade Federal de São Carlos/UFSCar)

Coordenador do Programa de Pós-Graduação em Geotecnia:

Prof. Titular Osni José Pejon

Presidente da Comissão de Pós-Graduação:

Prof. Titular Denis Vinicius Coury $\underline{\text { Resultado: }}$
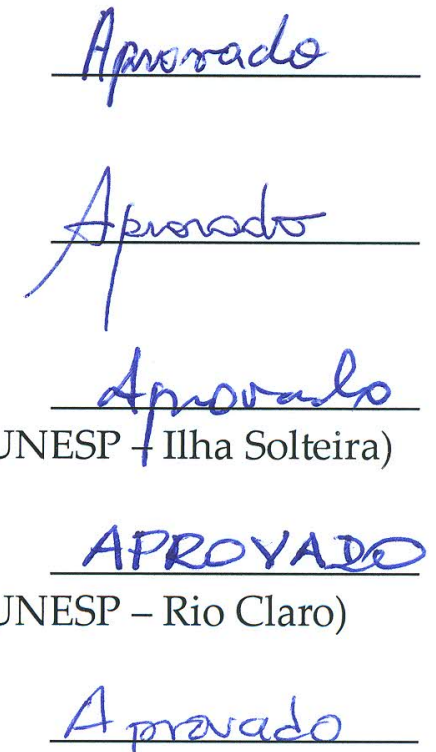
Ao meu pequeno grande amor... Gabriel 
Agradeço primeiro a Deus, pela minha vida e pela minha família, pois não chegaria onde estou hoje se não fossem estas pessoas maravilhosas que ajudaram a me tornar quem eu sou.

Aos meus pais pela dedicação e pelo apoio em toda minha vida acadêmica, por acreditarem e financiarem minha carreira. A todos os meus familiares que compreenderam minhas ausências nos finais de semana e entenderam que eu estava terminando minha tese.

Aos meus amigos jauenses que contribuíram com esta pesquisa, principalmente, Kiko, Jozrael e Deubles. Aos meus colegas de trabalho que auxiliaram no desenvolvimento do sistema, sempre contribuindo de maneira construtiva e dinâmica.

A minha amiga Gabriela Guedes por me manter firme nos momentos de desânimo e pela compreensão incondicional. A minha amiga Sandra por ter me incentivado a iniciar meu doutorado, e por cuidar de mim do plano espiritual (saudades).

Ao meu esposo Rafael por toda dedicação, companheirismo e paciência com esta esposa, mãe, engenheira, professora e doutoranda, sei que não foi fácil.

Ao meu amado filho por me fazer ser uma pessoa melhor e por me dar momentos de únicos de alegria e brincadeiras, inesquecíveis e tão revigorantes dentro da rotina do dia a dia.

Ao Departamento de Geotecnia, professores, técnicos e demais funcionários pelo apoio durante toda a pesquisa. A Capes pelo apoio financeiro. A Prefeitura Municipal de Jaú, IBGE, e SAEMJA pela liberação dos dados desta pesquisa.

Finalmente quero agradecer, em especial, ao prof. Oswaldo pela compreensão, apoio e motivação durante estes anos de orientação. 
"Assumir uma atitude responsável perante o futuro, sem uma compreensão do passado, é ter um objetivo sem conhecimento. Compreender o passado, sem um comprometimento com o futuro, é conhecimento sem objetivo."

Ronald T. Laconte 


\section{RESUMO}

\section{RODRIGUES, V. L. Sistema de apoio à gestão urbana estruturado em SIG:}

aplicação em Jaú-SP. 2013. 141 f. Tese (Doutorado) - Escola de Engenharia de São Carlos, Universidade de São Paulo, São Carlos, 2013.

Este trabalho apresenta os resultados de pesquisa direcionada à elaboração de um sistema de apoio à gestão urbana estruturado em Sistema de Informações Geográficas (SIG). O método de elaboração do sistema baseou-se na proposta geral da ESRI (1996) para organização de projetos de análise espacial em SIG. O sistema foi desenvolvido e aplicado no município de Jaú (SP). A base de dados espaciais necessária para operacionalizar as ações de gestão urbana e territorial com o sistema foi obtida a partir da coleta, do tratamento e da sistematização de informações produzidas pela pesquisa e secundárias, disponíveis em diferentes formatos e condições de acesso (dados geológico-geotécnicos, infraestrutura e planejamento urbano, restrições ambientais, etc.). O sistema apresenta uma interface personalizada em seis módulos temáticos (uso do solo, dados geotécnicos, infraestrutura urbana, relevo, preservação ambiental e áreas de risco), com diferentes ferramentas de visualização e de análise espacial na tela do computador ou com saída impressa, que facilitam a utilização pelos gestores municipais nas suas tarefas diárias. A pesquisa insere-se no aprimoramento de ferramentas tecnológicas e geotécnicas para o apoio da gestão territorial das cidades.

Palavras chave: gestão urbana, planejamento territorial, SIG, sistema customizado, base de dados integrada, Jaú (SP). 


\begin{abstract}
RODRIGUES, V. L. Support system for urban management structured in GIS: application in Jau-SP. 2013. 140 p. PhD thesis. Engineering School of Sao Carlos, University of São Paulo, Sao Carlos, 2013.
\end{abstract}

This paper presents the results of research aimed at development of a support system for urban management structured in Geographic Information System (GIS). The method of preparation of the system was based on the general proposal of ESRI (1996) for organization of spatial analysis projects in GIS. The system was developed and implemented in the city of Jau (SP). The spatial database needed to operationalize the actions of urban and territorial management with the system was obtained from the collection, processing and systematization of information produced by research and secondary, available in different formats and access conditions (geological-geotechnical data, infrastructure and urban planning, environmental constraints, etc.). The system features a custom interface into six thematic modules (land use, geotechnical data, urban infrastructure, signage, environmental preservation and risk areas) with different visualization and spatial analysis tools on the computer screen or printed output, facilitating the use by municipal managers in their daily tasks. The research is part of the improvement of technological and geotechnical tools to the support for the territorial management of cities.

Key words: Urban management, territorial planning, GIS, customized system, integrated database, Jau (SP). 


\section{LISTA DE FIGURAS}

Figura 3.1: Arquitetura do Sistema de Informações Geográficas (CÂMARA, 1999) ......................................26

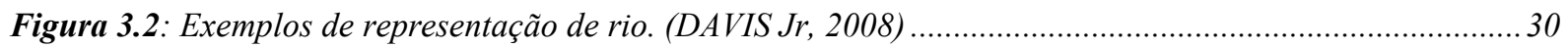

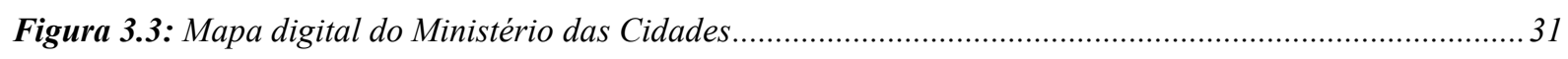

Figura 3.4: Modelo de sista desenvolvido para Klang Valley na Malásia (YAAKUP et. al.2005).....................35

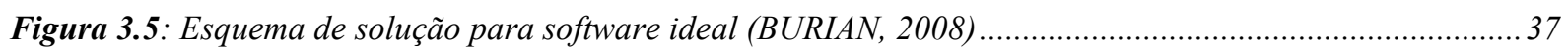

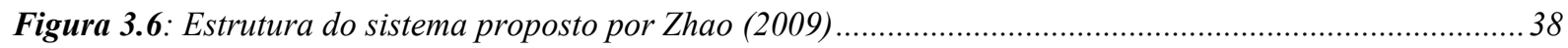

Figura 3.7: Fluxograma ilustrando os processos de concepção do SIG Urbano proposto por SLAMA \& TURKI, 2011 41

Figura 3.8: Componentes para representação dos territórios digitais urbanos. (ALMEIDA et. al. 2007) ..........41

Figura 3.9: Exemplo de informações que podem ser inseridas num Sistema de Apoio à Decisão para SIG. ...... 42

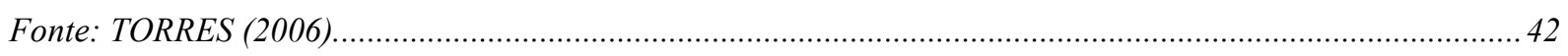

Figura 3.10: Visualização de dados vetoriais e raster.......................................................................4 44

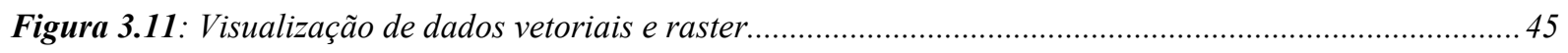

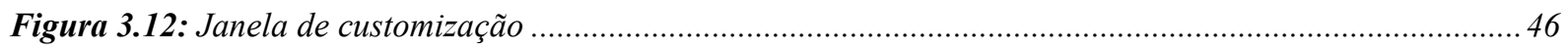

Figura 3.13: Caixa de diálogo para edição de scripts........................................................................4

Figura 3.14: Fluxograma da ordenação dos documentos cartográficos relacionados à metodologia de

Mathewson e Font (Modificado de ZUQUETTE \& GANDOLFI, 2004) .....................................................48

Figura 3.15: Perfil Geológico de Poço de água profundo elaborado através de perfilagem geofísica. ..............51

Figura 4.1: Localização da área de estudo no município de Jaú .................................................................5

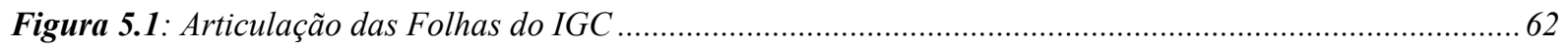

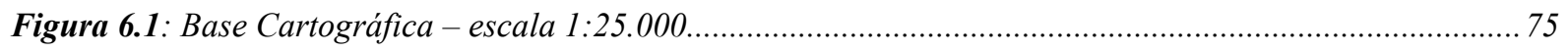

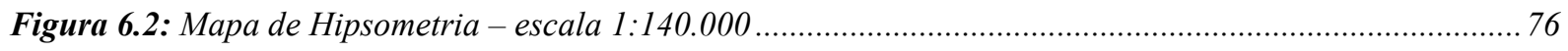

Figura 6.3: Fragmento do Mapa de Declividade - escala 1:25.000 ....................................................... 77

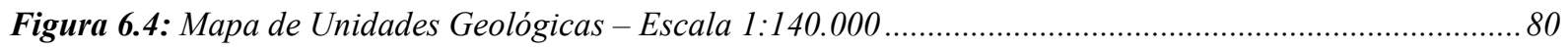

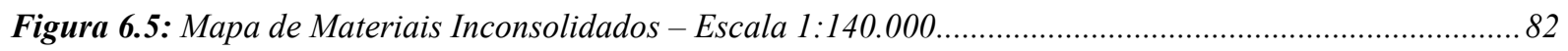

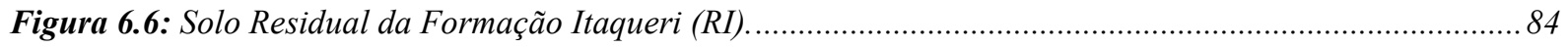


Figura 6.7: Solo Residual da Formação Adamantina (RA)

Figura 6.8: Solo Residual da Formação Serra Geral, apresentando estruturas reliquiares do basalto (R1SG). 85

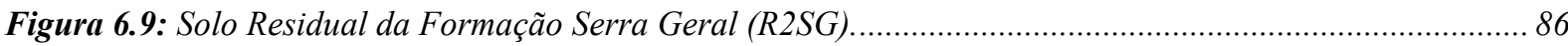

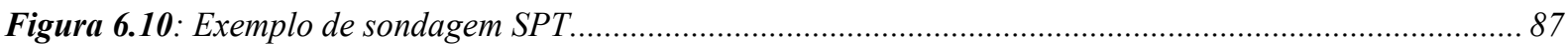

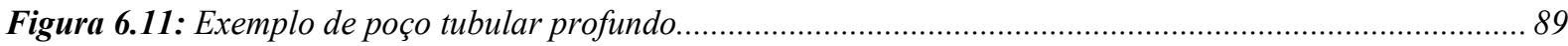

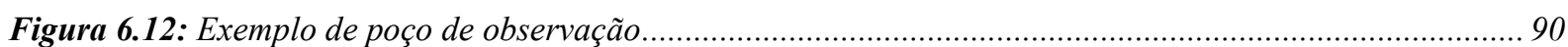

Figura 6.13: Afloramento rochoso na Rodovia Comandante Joao Ribeiro de Barros (SP 225)....................... 90

Figura 6.14: Fragmento do Mapa de Zoneamento ....................................................................................... 92

Figura 6.15: Ocorrências de inundações entre 2006-2011 (ROLLEMBERG et. al. 2011)..............................94

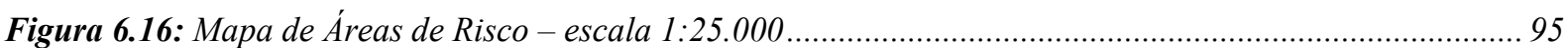

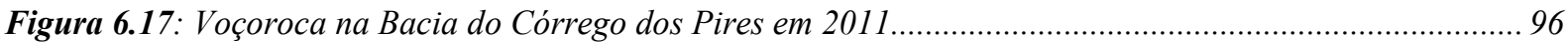

Figura 6.18: Local de Inundação na Área Central em 15 de novembro de 2011.......................................... 96

Figura 6.19: Vista área da RPPN - Amadeu Botelho (foto cedida pela Fatec-Jahu) ................................... 97

Figura 6.20: Fragmento do Mapa de Áreas de Proteção Ambiental.................................................................. 98

Figura 6.21: Exemplo de identificação de rede de água tubo de $50 \mathrm{~mm}$ em PVC......................................... 99

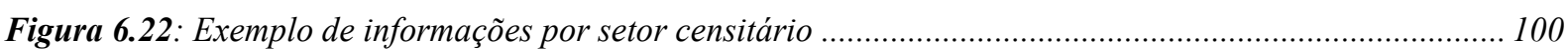

Figura 6.23: Exemplo de imóvel tombado com Grau de Preservação 1................................................... 101

Figura 6.24: Exemplo de imóvel tombado com Grau de Preservação 2. ....................................................... 102

Figura 6.25: Exemplo de imóvel tombado com Grau de Preservação 3.................................................. 102

Figura 6.26: Exemplo da demarcação de imóveis tombados .......................................................................... 103

Figura 6.27: Objetivos propostos para o Sistema. ........................................................................ 104

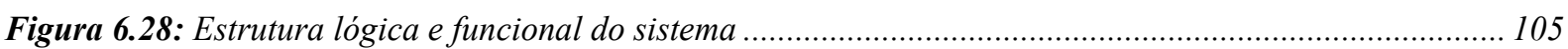

Figura 6.29: Temas dispostos em cada módulo do sistema ................................................................. 106

Figura 6.30: Tela de abertura do Sistema de Apoio à Gestão Urbana. ............................................................ 108

Figura 6.31: Exemplo da visualização da tela no Módulo 1 - Uso so Solo.................................................. 110

Figura 6.32: Exemplo da tela de vizualização de tabela de atributos - Tema: Poços Profundos......................111

Figura 6.33: Exemplo da tela de vizualização do layout em formato A1 - Módulo 2: Dados Geotécnicos...... 112

Figura 6.34: Equação utilizada para construir a consulta ........................................................................... 115

Figura 6.35: Áreas resultantes da consulta no Módulo 2............................................................... 115

Figura 6.36: Área resultante da seleção de Sondagens SPT ......................................................................... 116 
Figura 6.37: Função buscar utilizando CTM

Figura 6.38: Visualização do resultado da busca na tela e na tabela de atributos......

Figura 6.39: Visualização da gleba adicionada no Módulo 1 - Uso do Solo. 118

Figura 6.40: Visualização da gleba adicionada no Módulo 2 - Dados Geotécnicos...... 119

Figura 6.41: Visualização da gleba adicionada no Módulo 3 - Infraestrutura Urbana ........ 120

Figura 6.42: Visualização da gleba adicionada no Módulo 4 - Relevo 120

Figura 6.43: Visualização da gleba adicionada no Módulo 5 - Preservação Ambiental.. 121

Figura 6.44: Utilização da função "Calcular Áreas" 121

Figura 6.45: Visualização da gleba adicionada no Módulo 6- Áreas de Risco 122 


\section{LISTA DE TABELAS}

Tabela 3.1: Diretrizes da política Urbana segundo o Estatuto da Cidade (Cymbalista, 2001)

Tabela 3.2: Classificação do uso do solo urbano proposto por Rai \& Kumra (2011)

Tabela 3.3: Tipos de erosões urbanas mais comuns. Adaptado de Miranda (2005) e Oliveira \& Brito (1998)... 52

Tabela 5.1: Descrição dos dados levantados 61

Tabela 5.2: Temas que formam a base cartográfica. 63

Tabela 5.3: Restrições de declividade quanto ao uso de solo urbano (Adaptada de RODRIGUES, 2008) 64

Tabela 5.4: Mapas utilizados na pesquisa. 71

Tabela 5.5: Relação e características das fotografias aéreas utilizadas na pesquisa. 72

Tabela 5.6: Relação de programas utilizados na pesquisa 72

Tabela 6.1: Distribuição das classes de declividade na área de estudo 74

Tabela 6.2: Distribuição das unidades geológicas na área de estudo..... 79

Tabela 6.3: Distribuição dos materiais inconsolidados na área de estudo 81

Tabela 6.4 Síntese das características geológico-geotécnicas dos materiais inconsolidados mapeados. 83

Tabela 6.5: Dados dos ensaios de granulometria conjunta 84

Tabela 6.6: Exemplo da descrição dos dados de Sondagens SPT. 87

Tabela 6.7: Relação das informações de poços tubulares profundos. 88

Tabela 6.8: Relação das informações de poços de observação 89

Tabela 6.9: Descrição dos afloramentos cadastrados. 91

Tabela 6.10 Comprimento total das erosões lineares e área ocupada pelas erosões laminares 93

Tabela 6.11: Percentagem de distribuição das áreas de preservação ambiental..... 97

Tabela 6.12: Dados de infraestrutura urbana inseridos na base. 99

Tabela 6.13: Tabela de ícones presentes na tela inicial do projeto 107

Tabela 6.14: Tabela de icones presente em cada view 109

Tabela 6.15: Tabela dos ícones presentes na tela de tabelas. 111

Tabela 6.16: Tabela de ícones presentes na tela de layout. 113 
SIGLAS E ABREVIATURAS

\begin{tabular}{|c|c|}
\hline APP & Área de Preservação Permanente \\
\hline BD & Bando de Dados \\
\hline CATI & Coordenadoria de Assistência Técnica Integral \\
\hline CONPPAC & Conselho de Preservação do Patrimônio Cultural do Município de Jaú \\
\hline DAEE & Departamento de Águas e Energia Elétrica do Estado de São Paulo \\
\hline ECO-92 & Conferência Mundial sobre Desenvolvimento e Meio Ambiente \\
\hline EMG & Elementos Mínimos Geográficos \\
\hline ETA & Estação de Tratamento de Água \\
\hline ETE & Estação de Tratamento de Esgoto \\
\hline GPS & Global Positioning System \\
\hline HABITAT & Conferencia das Nações Unidas sobre Assentamentos Humanos \\
\hline IAC & Instituto Agronômico de Campinas \\
\hline IBGE & Instituto Brasileiro de Geografia e Estatística \\
\hline IGC & Instituto de Geografia e Cartografia \\
\hline IPT & Instituto de Pesquisas Tecnológica \\
\hline MDT & Modelo Digital de Terreno \\
\hline NA & Nível d’água \\
\hline PM & Prefeitura Municipal \\
\hline RPPN & $\begin{array}{l}\text { Reserva de Patrimônio Particular } \\
\text { Natural }\end{array}$ \\
\hline SAD & Sistema de Apoio à Decisão \\
\hline SAEMJA & Serviço de Água e Esgoto do Município de Jaú \\
\hline SIG & Sistema de Informações Geográficas \\
\hline SPT & Standart Penetration Test \\
\hline TIN & Triangular Irregular Network \\
\hline UDP & Unidade de Paisagem \\
\hline UGRHI & Unidade Hidrográfica de Gerenciamento de Recursos Hídricos \\
\hline UNESP & Universidade Estadual Paulista \\
\hline UTM & Universo Transverso de Mercator \\
\hline
\end{tabular}


1 INTRODUÇÃ

2 HIPÓTESES DE TRABALHO E OBJETIVOS ................................................................................... 17

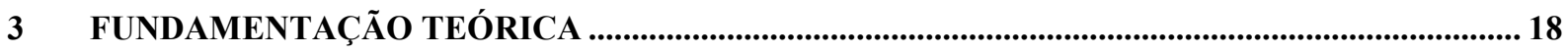

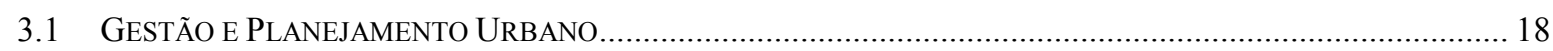

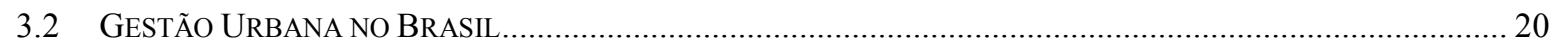

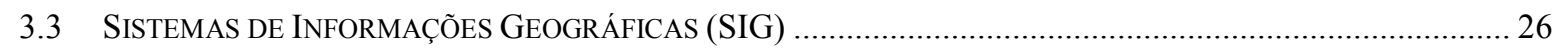

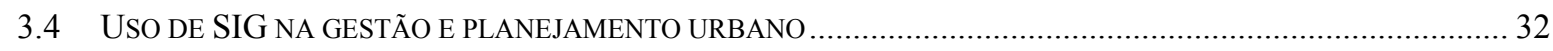

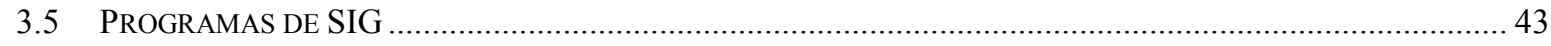

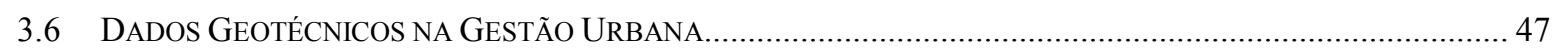

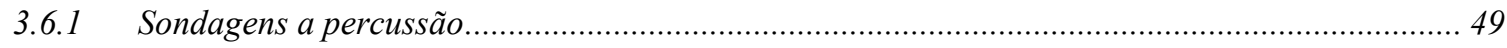

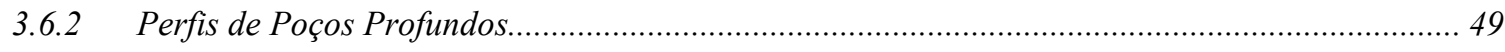

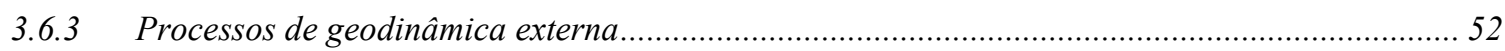

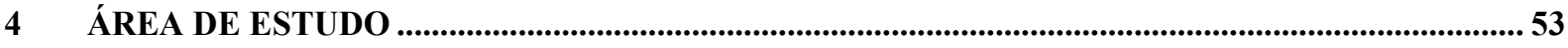

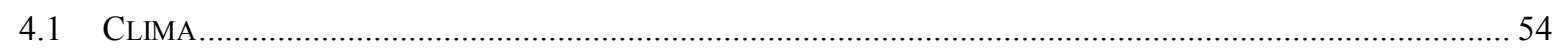

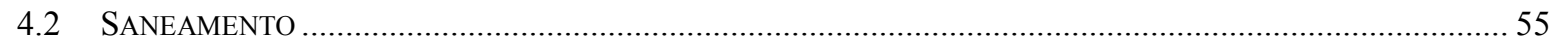

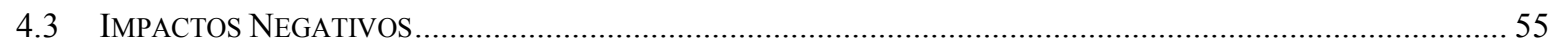

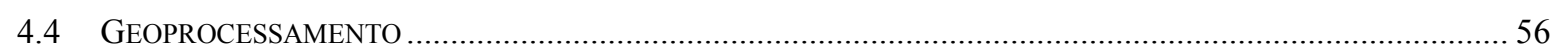

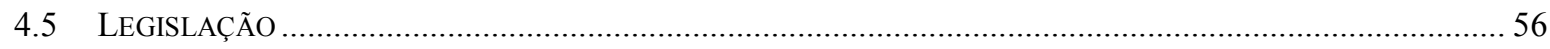

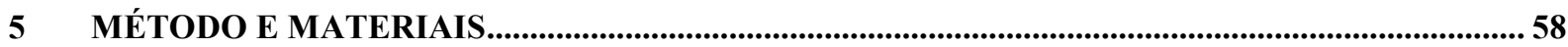

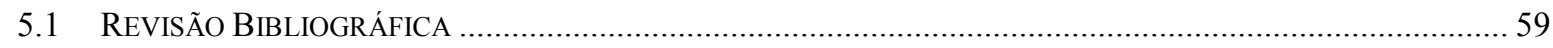

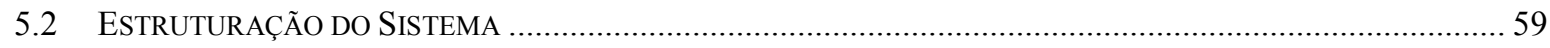

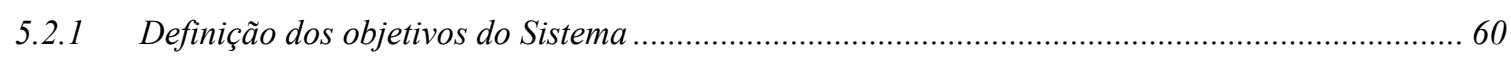

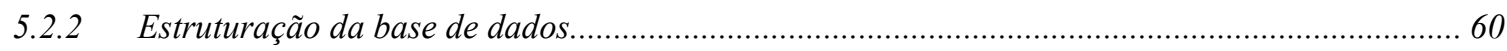

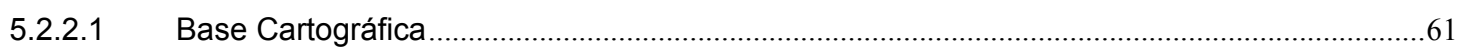

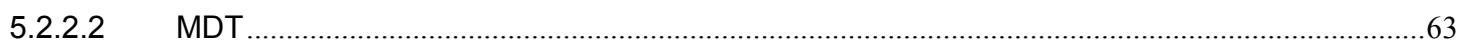

5.2.2.3 Mapa de Declividade e Mapa Hipsométrico ....................................................................................64

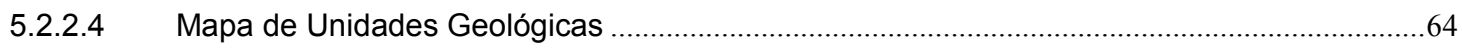

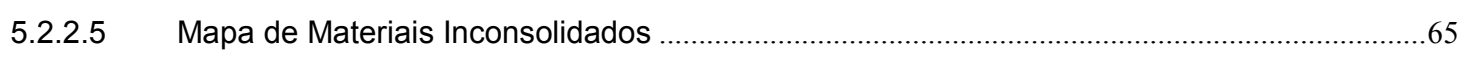

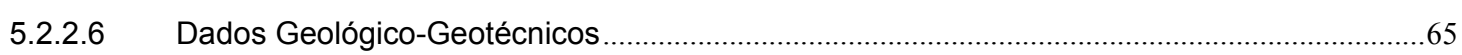

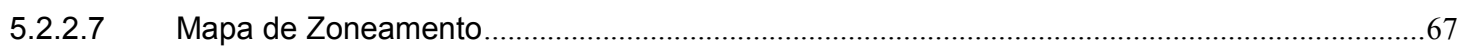

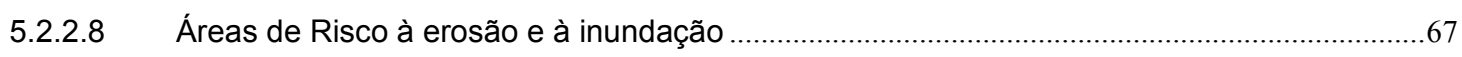

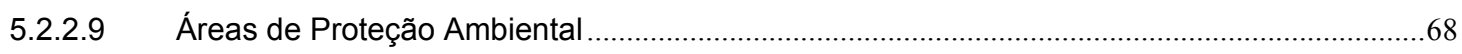

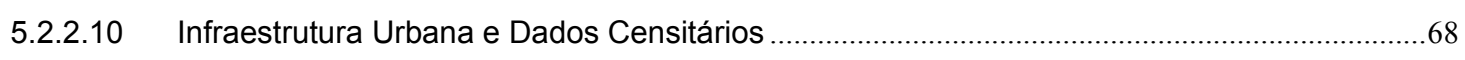

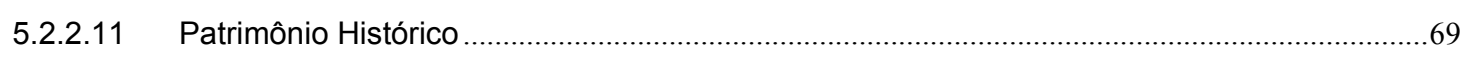

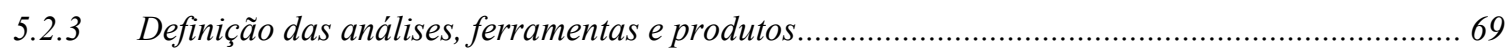


5.2.4 Definição das formas de apresentação dos resultados ............................................................6 69

5.3 APLICAÇÃo E VALIDAÇÃO DO SiSTEMA NA PREFEITURA DE JAÚ ...........................................................70

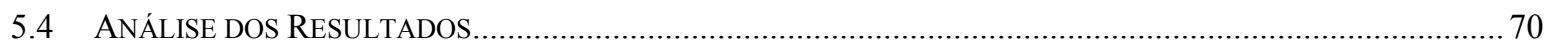

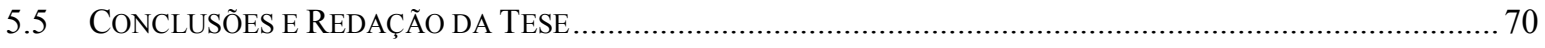

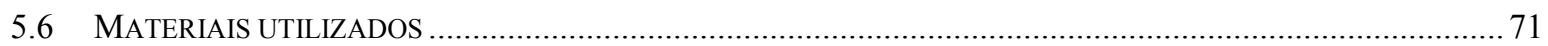

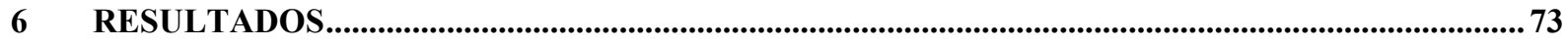

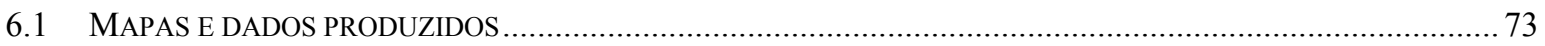

6.1.1 Base Cartográfica, Hipsometria e Declividade ...................................................................... 74

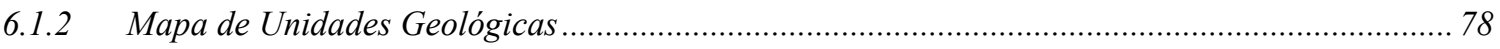

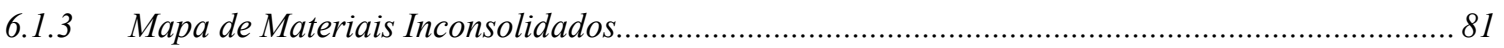

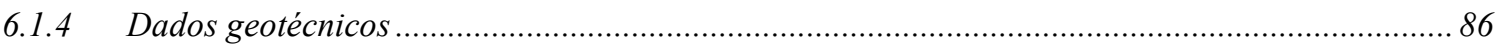

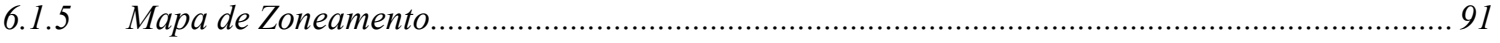

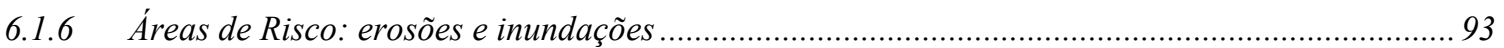

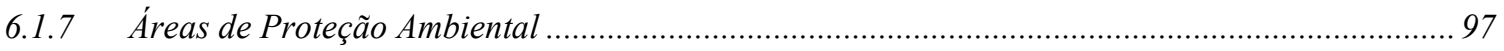

6.1.8 Infraestrutura Urbana e Dados Censitários ................................................................................ 99

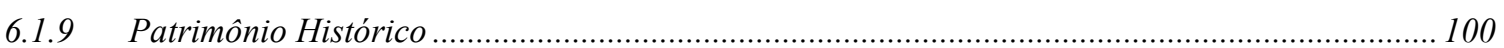

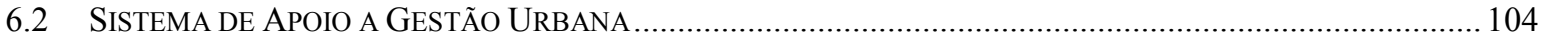

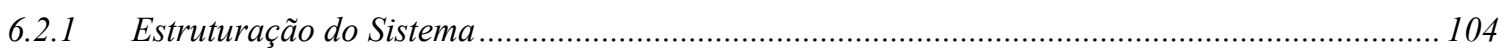

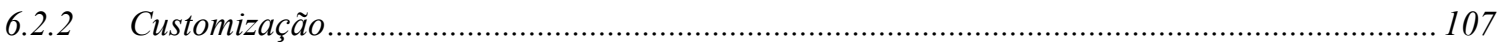

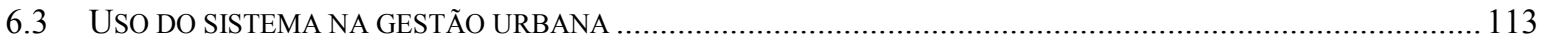

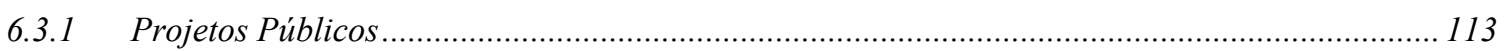

6.3.2 Certidão de uso de solo, aprovação de projetos e alvarás de funcionamento............................ 116

6.3.3 Certidão de Diretrizes para loteamentos ..................................................................... 118

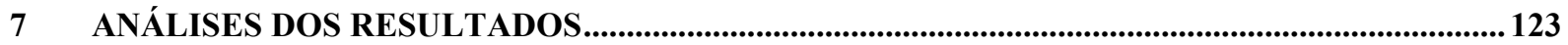

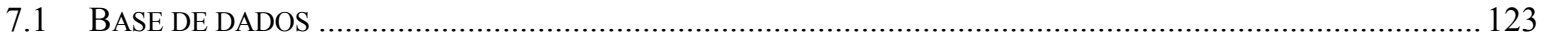

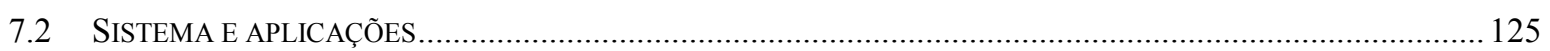

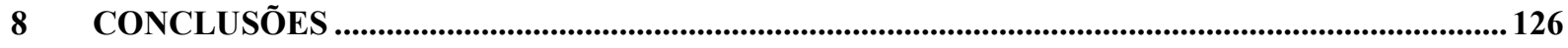

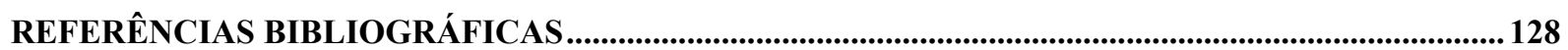

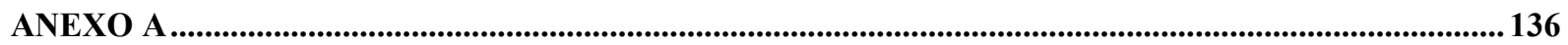

APENDICE A

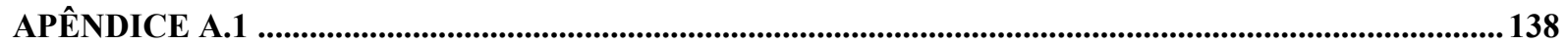

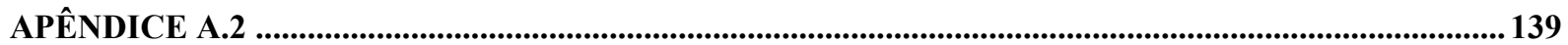




\section{INTRODUÇÃO}

O progresso tecnológico alcançado com a Revolução Industrial motivou as pessoas a saírem do campo migrando para as cidades, assim ao final do século XIX a urbanização desordenada culminou em diversos problemas na infraestrutura urbana forçando os políticos de vários países a participarem do processo de planejamento, que até então eram questões relacionadas apenas aos urbanistas (CHOAY, 2003).

O planejamento urbano surgiu como uma forma de enfrentar os problemas urbanos, marcando a mudança na forma de encarar a cidade, que até então era desenhada através de projetos visionários que a conceituavam como ideal (TAYLOR, 1998).

No Brasil a intensificação da urbanização aconteceu ao longo século XX e a partir da década de 70 a relação rural-urbana se inverteu, acarretando problemas que levaram as discussões sobre o planejamento urbano.

Em 2001, a Lei 10.257 chamada de Estatuto da Cidade criou instrumentos urbanísticos, sendo o Plano Diretor e a Lei de Uso e Ocupação do Solo (Zoneamento) seus representantes mais expressivos.

Contudo os planos e leis não se concretizam sem a gestão urbana, que inclui as atividades de planejamento, de operações e de correção, exercidas pelo 
poder público municipal. É na gestão urbana que são definidos os rumos da cidade, os encaixes dos novos empreendimentos na área consolidada, e as ações de correção dos problemas instalados.

O uso de Sistemas de Informações Geográficas (SIG) facilita e torna interativo o acesso, a consulta e a analise destes dados espaciais e vem se intensificando nos procedimentos técnicos da gestão urbana.

A proposta deste trabalho foi fornecer uma ferramenta tecnológica para apoiar o corpo técnico municipal na gestão urbana, ações de planejamento, de operação e de mitigação.

A presente pesquisa foi voltada ao desenvolvimento de um sistema computacional que integrasse as informações espaciais do meio-físico, sociais e ambientais, afim de relacionar dados, antes dispersos ou inexistentes.

Além desta introdução (Capitulo 1) esta tese esta estruturada nos capítulos descritos a seguir.

O capitulo 2 trata das hipóteses de trabalho e dos objetivos da pesquisa.

O capitulo 3 expõe os fundamentos teóricos e as bibliografias consultadas para elaboração deste trabalho.

O capitulo 4 apresenta a área de estudo e suas características principais.

O capitulo 5 sintetiza os materiais e métodos utilizados na construção deste trabalho.

O capitulo 6 apresenta os resultados da pesquisa.

O capitulo 7 discute os resultados da pesquisa.

O capítulo 8 mostra as conclusões obtidas com o trabalho realizado. 


\section{HIPÓTESES DE TRABALHO E OBJETIVOS}

As hipóteses de trabalho que direcionaram esta pesquisa foram:

- A gestão urbana depende do acesso rápido e combinado de diferentes informações de natureza espacial;

- O SIG pode ser uma ferramenta básica e viável para apoiar a gestão urbana em municípios brasileiros, tanto em atividades de planejamento, como nas operacionais e mitigadoras.

Os objetivos da pesquisa foram definidos a partir das hipóteses de trabalho descritas anteriormente. O objetivo principal deste trabalho foi a elaboração de um sistema computacional de apoio a gestão urbana utilizando SIG. Com base neste objetivo geral, estabeleceu-se o município de Jaú para o desenvolvimento e aplicação deste sistema, com a estruturação de uma base de dados espaciais de natureza física (geotécnica), social e ambiental, integrada com uma interface de consulta para o gestor municipal, apresentada na tela do computador e também com saída impressa. 


\section{FUNDAMENTAÇÃO TEÓRICA}

A pesquisa é o conjunto de investigações, operações e trabalhos intelectuais ou práticos que tenham como objetivo a descoberta de novos conhecimentos, a invenção de novas técnicas e a exploração ou a criação de novas realidades (KOURGANOFF,1990).

Este capítulo apresenta a fundamentação teórica da pesquisa desenvolvida, embasada em bibliografias pertinentes aos principais assuntos técnico-científicos que compuseram esta tese.

\subsection{Gestão e Planejamento Urbano}

O processo de urbanização é conhecido principalmente como a mudança espontânea da população rural para a cidade, sendo possível regular ou até mesmo planejar o assentamento urbano. O planejamento urbano é muitas vezes baseado apenas em experiências urbanistas e estimativas e não os resultados da análise espacial, que são utilizados muito raramente (BURIAN, 2008). 
A urbanização é inevitável e gera impactos, a fim de minimizar esses impactos deve-se ter uma infraestrutura urbana devidamente planejada, projetada, operada e mantida de modo que forneça a máxima eficiência. Parte do problema com a estrutura urbana de hoje é que ela foi construída em uma época em que o planejamento consciente era substancialmente diferente do que é hoje. Consequentemente, busca-se aperfeiçoar o sistema existente para alcançar os objetivos de desempenho urbano desejável (AIBINU, 2001).

Segundo Zhao (2009) o planejamento urbano é um importante instrumento da política pública, que o governo utiliza para regulamentar os recursos espaciais, instrui o desenvolvimento da cidade e do campo, mantém justiça social e fortalece a segurança pública.

Para Souza (2002) planejar remete ao futuro, à compreensão e à previsão de processos, enquanto que gestão indica o presente, e significa administrar a situação. Na mesma linha de pensamento o autor defende:

O planejamento é a preparação para a gestão futura, buscando-se evitar ou minimizar problemas e ampliar margens de manobra; gestão é a efetivação, ao menos em parte (pois o imprevisível e o indeterminado estão sempre presentes, o que torna a capacidade de improvisação e a flexibilidade sempre imprescindíveis), das condições que o planejamento feito no passado ajudou a construir.

Moura (2003) acredita que o planejamento ocorra em maior escala temporal e espacial, enquanto a gestão traduz o acompanhamento da dinâmica urbana nos processos de transformação em menor escala espacial e mais imediato.

Chadwick (1971) afirma que o planejamento é um processo de premeditação e da ação humana com base nessa previsão, e visa o melhor uso da terra e a melhoria no ambiente humano. O planejamento do ambiente da vida humano é, obviamente, mais fácil de dizer do que fazer, os aspectos físicos, socioeconômicos e ambientais são as principais preocupações e devem ser levados em consideração no processo de planejamento.

O crescimento na maioria dos países em desenvolvimento tornou-se uma questão global, devido ao desenvolvimento descontrolado e incontrolável, os aspectos físicos, ambientais e socioeconômicos, aparentemente sofreram o maior impacto. Aparentemente, o sistema de planejamento tem um papel importante na 
gestão e controle das tendências de desenvolvimento, sendo que os problemas urbanos são praticamente insuperáveis com relação a viciosa miséria urbana versus o esgotamento de recursos (YAAKUP et. al., 2005).

Assim, o planejamento e a gestão das áreas urbanas tornaram-se uma tarefa maior que lidar com questões e problemas devido ao crescimento, e sim tratar de problemas de poluição urbana, erosões, inundações, e destinação de resíduos. Portanto, a prática efetiva de planejamento e gestão urbana é imprescindível para delinear o limite de urbanização, minimizando ao máximo o detrimento dos recursos naturais.

Rolnik (1994) defende que se desejamos alguma possibilidade de futuro para nossas cidades, fica cada vez mais claro que isto dependerá da capacidade de defesa e auto-organização da cidadania, o que pressupõe a capacidade do governo local de estabelecer espaços de interlocução com a sociedade no processo de elaboração das políticas públicas.

\subsection{Gestão Urbana no Brasil}

Após 11 anos de tramitação, o Congresso Nacional aprovou em julho de 2001 a Lei 10.257, mais conhecida como Estatuto da Cidade (CYMBALISTA, 2001). Esta Lei regulamenta o capítulo de política urbana, artigos 182 e 183, da constituição Federal de 1988, oferecendo aos municípios um conjunto de instrumentos de intervenção e ordenamento de seus territórios, inovando a concepção de gestão urbana e territorial.

O Estatuto da Cidade traz um conjunto de princípios e uma série de instrumentos para o planejamento e gestão urbana, e delega para cada município a função de mobilização e aplicação destes instrumentos, a partir de processos políticos e democráticos. A Tabela 3.1 traz as diretrizes gerais do artigo $2^{\circ}$ do Estatuto da Cidade, elas tratam dos parâmetros que devem orientar a construção da política urbana, para se garantir a democracia e sustentabilidade. 
Tabela 3.1: Diretrizes da política Urbana segundo o Estatuto da Cidade (Cymbalista, 2001)

\begin{tabular}{|c|c|}
\hline$N^{\circ}$ & Diretriz \\
\hline$I$ & $\begin{array}{l}\text { Garantia do direito a cidades sustentáveis, entendido como o direito à terra urbana, à } \\
\text { moradia, ao saneamento ambiental, à infra-estrutura urbana, ao transporte e aos serviços } \\
\text { públicos, ao trabalho e ao lazer, para as presentes e futuras gerações; }\end{array}$ \\
\hline II & $\begin{array}{l}\text { Gestão democrática por meio da participação popular e de associações representativas } \\
\text { dos vários segmentos da comunidade na formulação, execução e acompanhamento de } \\
\text { plano e programas e projetos de desenvolvimento urbano; }\end{array}$ \\
\hline III & $\begin{array}{l}\text { Cooperação entre os governos, a iniciativa privada e os demais setores da sociedade no } \\
\text { processo de urbanização, em atendimento ao interesse social; }\end{array}$ \\
\hline IV & $\begin{array}{l}\text { Planejamento do desenvolvimento das cidades, da distribuição espacial da população e } \\
\text { das atividades econômicas do município e do território sob sua área de influência, de } \\
\text { modo a evitar e corrigir as distorções do crescimento urbano e seus efeitos negativos } \\
\text { sobre o meio ambiente; }\end{array}$ \\
\hline V & $\begin{array}{l}\text { Oferta de equipamentos urbanos e comunitários, transporte e serviços públicos } \\
\text { adequados aos interesses e necessidades da população e às características locais; }\end{array}$ \\
\hline VI & $\begin{array}{l}\text { Ordenação e controle do uso do solo, de forma a evitar: a utilização inadequada dos } \\
\text { imóveis urbanos, a proximidade de usos incompatíveis ou inconvenientes, o parcelamento } \\
\text { do solo, a edificação ou o uso excessivos ou inadequados em relação à infra-estrutura } \\
\text { urbana, a instalação de empreendimentos ou atividades que possam funcionar como } \\
\text { pólos geradores de tráfego, sem a previsão da infra-estrutura correspondente, a retenção } \\
\text { especulativa de imóvel urbano, que resulte na sua subutilização ou não utilização, a } \\
\text { deterioração das áreas urbanizadas e a poluição e a degradação ambiental; }\end{array}$ \\
\hline VII & $\begin{array}{l}\text { Integração e complementaridade entre as atividades urbanas e rurais, tendo em vista o } \\
\text { desenvolvimento socioeconômico do Município e do território sob sua área de influência; }\end{array}$ \\
\hline VIII & $\begin{array}{l}\text { Adoção de padrões de produção e consumo de bens e serviços e de expansão urbana } \\
\text { compatíveis com os limites da sustentabilidade ambiental, social e econômica do } \\
\text { Município e do território sob sua área de influência; }\end{array}$ \\
\hline$I X$ & Justa distribuição dos \\
\hline$x$ & $\begin{array}{l}\text { Adequação dos instrumentos de política econômica, tributária e financeira e dos gastos } \\
\text { públicos aos objetivos do desenvolvimento urbano, de modo a privilegiar os investimentos } \\
\text { geradores de bem-estar geral e a fruição dos bens pelos diferentes segmentos sociais; }\end{array}$ \\
\hline$X I$ & $\begin{array}{l}\text { Recuperação dos investimentos do Poder Público de que tenha resultado a valorização } \\
\text { de imóveis urbanos; }\end{array}$ \\
\hline XII & $\begin{array}{l}\text { Proteção, preservação e recuperação do meio ambiente natural e construído, do } \\
\text { patrimônio cultural, histórico, artístico, paisagístico e arqueológico; }\end{array}$ \\
\hline XIII & $\begin{array}{l}\text { Audiência do Poder Público municipal e da população interessada nos processos de } \\
\text { implantação de empreendimentos ou atividades com efeitos potencialmente negativos } \\
\text { sobre o meio ambiente natural ou construído, o conforto ou a segurança da população; }\end{array}$ \\
\hline XIV & $\begin{array}{l}\text { Regularização fundiária e urbanização de áreas ocupadas por população de baixa renda } \\
\text { mediante o estabelecimento de normas especiais de urbanização, uso e ocupação do } \\
\text { solo e edificação, consideradas a situação socioeconômica da população e as normas } \\
\text { ambientais; }\end{array}$ \\
\hline$X V$ & $\begin{array}{l}\text { Simplificação da legislação de parcelamento, uso e ocupação do solo e das normas } \\
\text { edilícias, com vistas a permitir a redução dos custos e o aumento da oferta dos lotes e } \\
\text { unidades habitacionais; }\end{array}$ \\
\hline$X V I$ & $\begin{array}{l}\text { Isonomia de condições para os agentes públicos e privados na promoção de } \\
\text { empreendimentos e atividades relativos ao processo de urbanização, atendido o } \\
\text { interesse social. }\end{array}$ \\
\hline
\end{tabular}


O Estatuto da Cidade apresenta caminhos a serem seguidos e estabelece objetivos claros a serem alcançados, em sintonia com os acordos decorrentes da Conferência Mundial sobre Desenvolvimento e Meio Ambiente (ECO92) realizada no Rio de Janeiro, e a Conferencia das Nações Unidas sobre Assentamentos Humanos (Habitat II), realizada no ano de $96 \mathrm{em}$ Istambul.

De acordo com Leonelli (2003) a Agenda 21 é um programa de ação em forma de recomendações, que incorpora simultaneamente os direitos ao desenvolvimento e um meio ambiente saudável. Algumas das pautas relativas às dimensões sociais e econômicas deste instrumento são:

a. dinâmica demográfica e sustentabilidade;

b. proteção à saúde humana;

c. promoção de assentamentos humanos sustentáveis;

d. elaboração de políticas para o desenvolvimento sustentável.

Segundo Leonelli (op.cit) a conferência HABITAT II, teve como tema central "Adequada habitação para todos e o desenvolvimento de assentamentos humanos em um mundo em urbanização". Com esta reunião foi elaborada a Agenda Habitat, que tem como pontos fundamentais:

a. Descentralização e valorização do poder local: as autoridades locais são reconhecidas como agentes primordiais para promoção de melhorias dos assentamentos humanos, no entanto as causas estruturais e problemas urbanos são de âmbito nacional e internacional, mas a ação para suas soluções pode ser mais efetiva no poder local;

b. Participação na formulação de políticas públicas: participação democrática da sociedade civil para elaboração e gestão das políticas públicas;

c. Conceito de infraestrutura: a rede de infraestrutura deve ser pensada através do viés de desenvolvimento sustentável, de acordo com parâmetros através de produção e consumo, a utilização de recursos naturais, adequados à gestão ambiental.

d. Intervenção nos assentamentos precários: substituição do caráter provisório dos assentamentos precários, por estratégias de intervenção e melhoria, através de consolidação urbanização.

Um dos principais instrumentos para o planejamento e a gestão urbana é o Plano Diretor, estabelecido pelo Estatuto da Cidade, que entre outros critérios, 
estabelece que os municípios com mais de 20 mil habitantes deveriam elaborar o Plano Diretor até 11 de outubro de 2006 (CYMBALISTA, 2001).

Dentro deste instrumento municipal, o poder público deve promover o adequado ordenamento territorial, mediante o planejamento e o controle do uso do solo (parcelamento e ocupação). Também se evidencia a competência municipal para adotar as medidas que favoreçam o desenvolvimento territorial, com sustentabilidade cultural, social, política, econômica, ambiental e institucional.

Segundo Mota (1999) um Plano Diretor de Desenvolvimento Urbano, para contemplar dimensões econômicas, sociais e ambientais, deve considerar as seguintes etapas:

a. Levantamento de dados

- Meio físico (características climáticas, topografia, geomorfologia, geologia e solos, hidrologia superficial, hidrogeologia).

- Meio biótico e ecossistemas;

- Meio antrópico (aspectos demográficos, uso do solo, infraestrutura, qualidade ambiental existente, aspectos socioeconômicos, políticos e institucionais)

b. Diagnóstico

- Mapeamento de áreas consideradas próprias ou impróprias para ocupação urbana;

- Identificação das áreas mais suscetíveis à erosão;

- Identificação das áreas críticas de poluição atmosférica;

- Caracterização de recursos hídricos;

- Indicação das áreas com vegetação e degradadas;

- Níveis de ruídos;

- Identificação de áreas destinadas a preservação ou ao uso controlado, de valor ecológico, de recargas de aquíferos, de amortecimento de cheias, etc.;

- Identificação dos recursos naturais sujeitos à degradação;

- Identificações de usos de maior impacto ambiental;

- Mapeamento de necessidades básicas de infraestrutura;

- Barreiras ao crescimento das cidades, naturais ou imposta pelo homem;

- Áreas de possível para expansão urbana.

c. Prognóstico 
- Definição do uso dos solos através de cartas de Zoneamento;

- Definição de áreas a serem ocupadas e preservadas;

- Estabelecimento de diretrizes para o parcelamento do solo, de acordo com cada unidade identificada no zoneamento;

- Infraestrutura a ser implantada;

- Sistema viário;

- Níveis de qualidade a serem alcançados;

- Desenvolvimento socioeconômico;

- Sistema de planejamento e gestão integrados.

A estrutura proposta por Mota (1999) é parcialmente utilizada, o que ocorre geralmente é a ausência de informações físicas na execução de Planos Diretores. Os levantamentos necessários normalmente seguem linhas sociais, culturais e econômicas.

A maioria dos planos, no Brasil, tem como foco o desenvolvimento sustentável voltado para o cidadão, mas as características locais, muitas vezes, não são exploradas, e isto acarreta muitos prejuízos para as cidades, pois cada local tem características especificas que devem ser contempladas na gestão pública.

Nos últimos anos o país teve vários locais devastados por eventos naturais, uma soma de precipitações intensas e "áreas de risco". Temos equipamentos que nos alertam sobre o clima, portanto temos informações preciosas a respeito de possíveis eventos drásticos, o que muitas vezes não conhecemos são as áreas de risco, que podem ser levantadas por mapeamentos geológicogeotécnicos.

Em 16 de agosto de 2011 foi incluído na pauta de reunião da CDR (Comissão de Desenvolvimento Regional e Turismo) um projeto de Lei Federal proposto pelo senador Rodrigo Rollemberg, que mostra claramente a preocupação da inserção de dados geotécnicos na gestão urbana (CASTANHO, 2011). Segue o texto do projeto de Lei: 
Altera a Lei $n^{\circ}$ 10.257/2001 - que regulamenta os arts. $182 \mathrm{e}$ 183 da Constituição Federal estabelece diretrizes gerais da política urbana e dá outras providências: para dispor que a elaboração do plano diretor será orientada por carta geotécnica que determine, com base em critérios técnicos de segurança geológica, as áreas passíveis de ocupação urbana; estabelece que os Municípios cujos planos diretores tenham sido elaborados em desacordo com o disposto nesta Lei deverão promover as necessárias adaptações no prazo máximo de dois anos, contados de sua publicação.

Este é apenas um projeto de Lei, contudo fica clara a preocupação com a falta de informações essenciais à ocupação territorial ordenada e baseada na realidade de cada área específica.

De acordo com Braga (2001) outra Lei que deve ser integrada ao Plano Diretor é a de Zoneamento, certamente é o instrumento urbanístico mais criticado, tanto por sua eventual ineficácia, quanto por seus efeitos perversos, como especulação imobiliária e segregação socioespacial.

A forma mais tradicional é o zoneamento de uso e ocupação do solo, de matriz funcionalista, que prevê uma segregação de usos em industrial, comercial e residencial, com maior ou menor grau de flexibilidade.

O zoneamento usualmente é definido em duas escalas: a primeira, denominada de macrozoneamento, que consiste na delimitação das zonas urbana, de expansão urbana, rural e macrozonas especiais do município. A segunda escala refere-se ao zoneamento propriamente dito, que irá estabelecer as normas de uso e ocupação para cada macrozona, especialmente e mais detalhadamente para as zonas da área urbana.

Resumidamente, 'o zoneamento urbano divide a cidade em zonas homogêneas, para as quais são designados usos (segregados ou mistos) e especificadas as densidades de ocupação através de índices urbanísticos como o coeficiente máximo de aproveitamento, a taxa de ocupação máxima, os recuos mínimos, a área mínima dos lotes, a frente mínima dos lotes e o gabarito máximo das edificações

Normalmente o modelo de cidade que trabalhamos metodologicamente se baseia na cidade ideal, confrontando-se com a cidade real, uma vez que não se leva em conta os conflitos pela apropriação do solo. A ausência de políticas 
públicas no tratamento dos espaços urbanos ressalta o descompasso entre 0 crescimento real e os instrumentos utilizados para intervenção desta realidade.

\subsection{Sistemas de Informações Geográficas (SIG)}

Segundo Yuaça (2003) os SIG são conjuntos de programas, equipamentos, metodologias, dados e pessoas (usuário), perfeitamente integrados, de forma a tornar possível a coleta, o armazenamento, o processamento e a análise de dados georreferenciados, bem como a produção de informação derivada de sua aplicação.

Os Sistemas de Informações Geográficas têm características que permitem, não só a geração e gestão de bases de dados de grande porte, mas também o apoio à estruturação de problemas complexos (ANGELINI et. al., 2000).

A Figura 3.1 representa a arquitetura usual dos programas em SIG. A interface é o contato do usuário com a máquina, no nível intermediário, um SIG tem os mecanismos de processamento de dados espaciais, onde há a inserção e integração dos dados, a consulta e análise espacial e ainda a visualização e plotagem (Câmara, 1999).

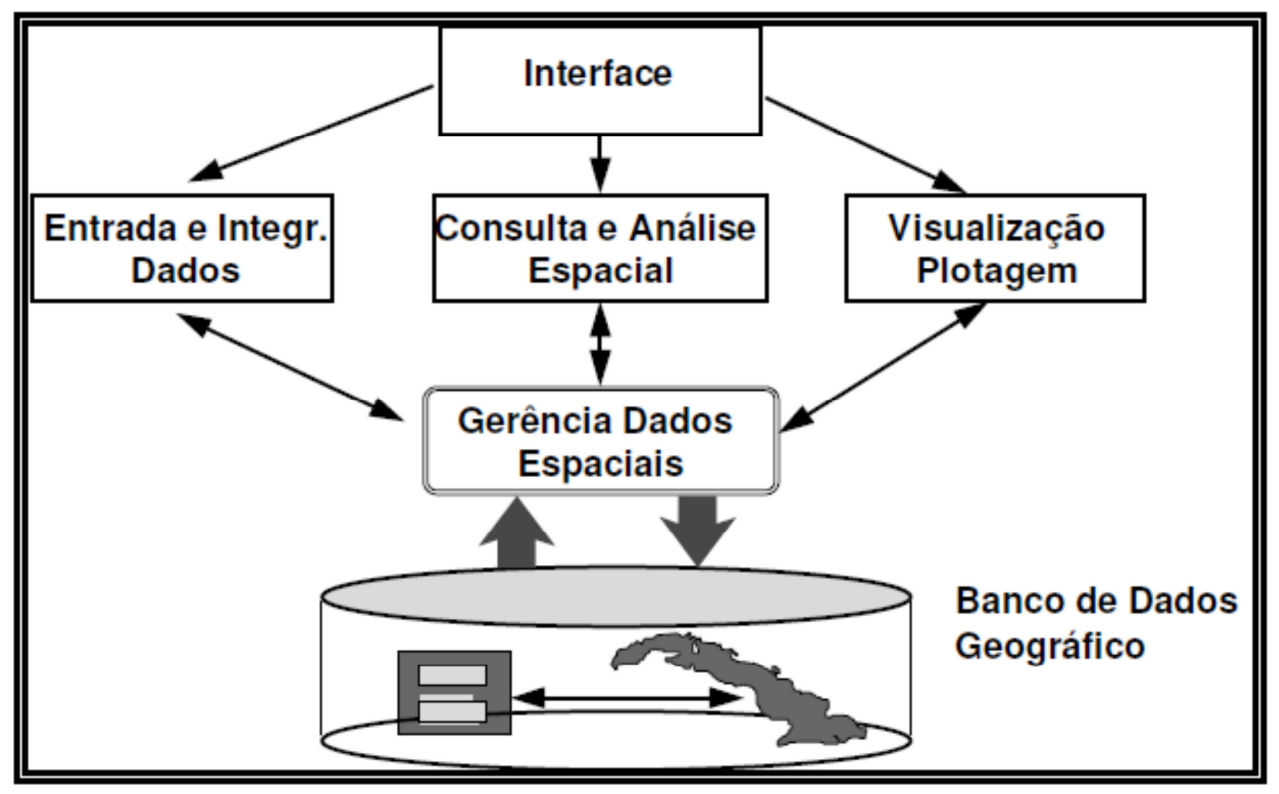

Figura 3.1: Arquitetura do Sistema de Informações Geográficas (CÂMARA, 1999) 
Mais internamente ao programa, um sistema de gerência de bancos de dados geográficos faz o armazenamento e recuperação dos dados espaciais e seus atributos. Cada sistema é construído em função de seus objetivos e necessidades, podendo implementar estes componentes de forma distinta, mas todos os subsistemas citados devem estar presentes num software SIG.

Alguns softwares de SIG disponibilizam ambientes com linguagens próprias dos sistemas, para o desenvolvimento de aplicações, como por exemplo, o trabalho realizado por Augusto Filho et. al. (2002), que elaboraram um sistema de gerenciamento de passivo ambiental com auxílio do software Arcview. Os autores desenvolveram uma interface gráfica utilizando a linguagem AVENUE (própria do Arcview), possibilitando consultas rápidas e ilustrativas das informações do passivo ambiental, sem a necessidade de treinamento especial para utilização do aplicativo.

A linguagem de programação, direcionada à objetos, conhecida como Visual Basic, foi acoplado à biblioteca MapObjects2.2 (ESRI $\left.{ }^{\circledR}\right)$, para elaboração de um banco de dados geotécnicos no trabalho de doutorado desenvolvido por Bastos (2005). Este tipo de linguagem permite a manipulação dos dados geoespaciais para posteriormente serem utilizados em bibliotecas cartográficas.

Esta nova tendência do uso de SIG, que é a criação de ambiente próprio para aplicações específicas aos dados geoespaciais, é chamada de "small GIS" (CÂMARA et.al., 2003).

A utilização dos softwares SIG para o mapeamento geotécnico, tem se mostrado de extrema importância em atividades, como as de caracterizações geológico-geotécnicas (VIEIRA et al.,2005) e planejamento urbano (WALSBY, 1998; RUIZ et al., 2002).

O governo metropolitano de Tókio (Tokyo Metropolitan Government TMG), por exemplo, utilizou SIG no desenvolvimento de uma base de dados geotécnicos, foram inseridos dados como: sondagens à percussão, poços profundos e nível de água subterrânea, numa base cartográfica digital e georreferenciada (ISHI et. al.,1992).

Este projeto do TMG possibilitou vários tipos de correlações entre as informações presentes no sistema e a impressão, tanto dos resultados de análises, quanto de boletins de sondagens ou outras informações de interesse do usuário. 
O potencial do SIG, muitas vezes, é confundido com a manipulação complexa de dados cartográficos e alfanuméricos, mas a principal potencialidade do sistema é a análise espacial, portanto devem ser focados os conceitos e os métodos no uso do sistema, e não somente utilizá-lo como caixa de ferramentas (MARTIN, 1996).

Paralelamente ao uso de qualquer sistema de informações geográficas, está o do banco de dados (BD), que é um componente, inerente a qualquer software deste tipo.

O banco de dados em SIG armazena as informações e dados descritivos (numéricos e textos), além dos de natureza gráfica, locacional e os relacionamentos entre eles.

Segundo Silva (1999), o nível conceitual do banco de dados deve ser acessado por seus administradores, que devem ter experiência e qualificação para tal, podendo ser definidos diversos graus de autorização para os demais usuários, como:

a. leitura: permite somente a leitura de dados, sem autorização para codificá-los;

b. entrada: permite a entrada de dados novos, mas não modificar os já existentes;

c. atualização: permite a modificação dos dados, mas não a eliminação;

d. índice: permite a criação e eliminação de índices;

e. alteração: permite acrescentar ou eliminar atributos em uma relação;

f. redução: permite eliminar relações.

Para Moura (2003), a execução de um banco de dados que seja a representação virtual de uma situação geográfica, possibilita a realização de estudos preditivos, relacionados com causa e efeito. Tais estudos são denominados de cenários, que tem o objetivo de gerar subsídios para intervenções mais seguras em uma cidade real.

Assim criam-se os melhores cenários possíveis para a promoção do desenvolvimento territorial urbano, de maneira ordenada e sustentável. Na busca pela gestão integrada necessita-se de uma imensa gama de dados.

Para a implantação do banco de dados é utilizado um sistema de gerenciamento de banco de dados (SGBD). O SGBD deve oferecer: controle de acesso, gerenciamento das transações, segurança, restrições de integridade e backup. 
Além dos gerenciadores próprios de determinados programas de SIG. Existem muitos SGBD comerciais que interagem com os softwares, como por exemplo: Access, dBASE, Visual Basic, entre outros (ALVES, 2004).

$A$ adoção generalizada de normas que padronizam o acesso à banco de dados geográficos (SIG aberto), permite que bases de dados armazenadas, em um SGBD qualquer, possam ser acessadas por uma grande variedade de programas-clientes, cada qual especializado em um certo conjunto de funções: SIG completos, aplicativos desktop mapping, sistemas alfanuméricos convencionais, programas CAD, entre outros (DAVIS JR, 1999) .

Para a execução deste tipo de banco de dados, deve-se estabelecer algumas diretrizes, sobre o formato, o objetivo e até mesmo os resultados esperados para o sistema.

Augusto Filho (2005), em relatório técnico que trata da estruturação de um banco de dados geológico-geotécnico, a partir de sondagens da cidade de Belo Horizonte, abordou desde as determinações e relações internas dos elementos incluídos, até a modelagem em ambiente de SIG dos mesmos.

São inúmeras as informações que podem ser inseridas em um banco de dados geográficos, estes dados são representados por pontos, linhas ou polígonos, que recebem informações individualizadas.

Segundo Bundy et. al. (1995) a forma de representação depende do tipo de dado, da escala e da analise que será realizada. Um exemplo é o rio, apresentado na Figura 3.2, ele pode ser representado de diversas formas.

A representação mais comum é feita com um objeto vetorial linear lançado sobre seu eixo, normalmente para pequenas escalas (Figura 3.2a). Em mapas com escalas maiores onde o rio é visível, a representação é feita com linhas separadas para cada margem (Figura 3.2b).

Pode-se ainda representar o rio esquematicamente como uma rede, composta por nós e arcos, muita utilizada em análises de drenagem e hidrologia, onde a percepção da topologia da bacia é mais importante que a aparência gráfica (Figura 3.2c). Por fim, pode-se utilizar um polígono fechado, simulando a ocupação da água (Figura 3.2d). 


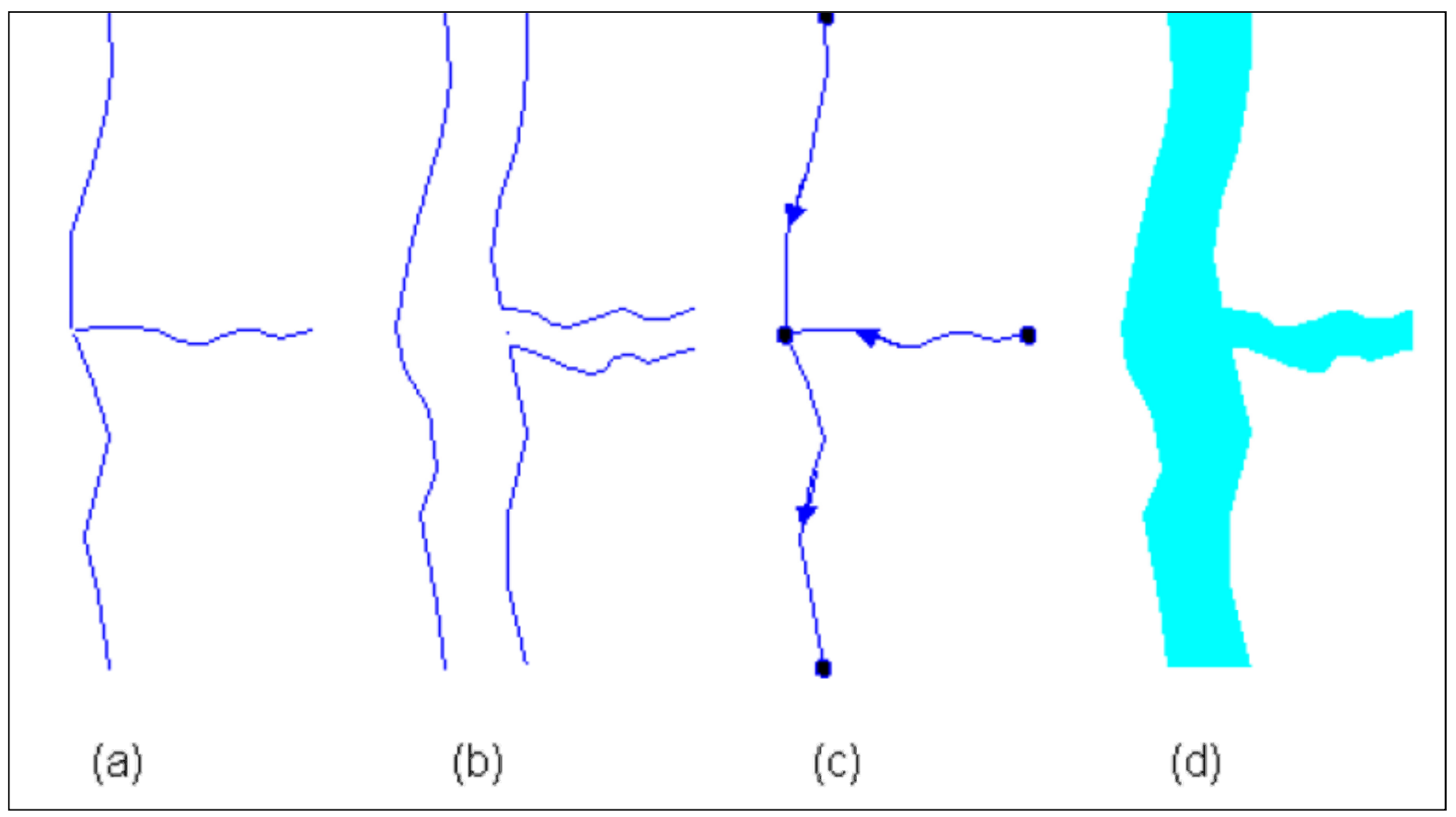

Figura 3.2: Exemplos de representação de rio. (DAVIS Jr, 2008)

Segundo Cintrão \& Cintrão (2003), os ensaios propiciados por um sistema SIG, auxiliam em complexas análises de futurabilidade, dando maior transparência às decisões governamentais estratégicas. O desenvolvimento de modelos computacionais visando dar suporte à análise espacial, encontram a base ideal de implementação nos SIG.

De acordo Rai \& Kumra (2011) os sistemas de informação também oferecem interpretação dos dados físicos (espacial) com os dados socioeconômicos e, assim, proporcionam uma ligação importante no processo global de planejamento, tornando-se mais eficaz e significativo

Por apresentar possibilidades de integração sistemática, os SIG, proporcionam o ambiente adequado de formulação metodológica em processos de avaliação ambiental e ordenamento territorial. O projeto GEOMETA, por exemplo, definiu elementos mínimos geográficos (EMG) para análise espacial no planejamento local e para a avaliação da qualidade ambiental. Este projeto foi desenvolvido pela Universidade de Évora, com o recurso de programação Avenue (NEVES, 2000).

Um SIG deve possibilitar que os equipamentos sociais e de infraestrutura sejam espacialmente identificados e perfeitamente caracterizados, de 
forma a permitir o conhecimento da oferta de serviços urbanos colocados à disposição da população, e em contrapartida, a demanda social nessas áreas.

De acordo com Priya (1995) os Sistemas de Informações Geográficas tornaram-se um método de análise predominante na engenharia civil, por serem flexíveis e manipuláveis. Recolher e processar dados espaciais acima ou abaixo a superfície da terra tem fornecido uma ferramenta poderosa em aplicações de engenharia civil.

Para Burian (2008) a maioria dos softwares é uma espécie de "caixa preta" do modelo, que são fáceis para os usuários, mas qualquer um deles não é ideal para utilização para o planejamento urbano. Existem várias ferramentas e softwares utilizados para o planejamento urbano, mas nenhum deles é um programa para uso de rotina, o que é condição necessária para a maioria dos planejadores urbanos.

Recentemente, foi elaborado, pelo Ministério das Cidades, um mapa digital que reúne cerca de 800 indicadores sociais, demográficos, eleitorais e econômicos das regiões, dos Estados e de todos os 5.564 municípios brasileiros (Figura 3.3).

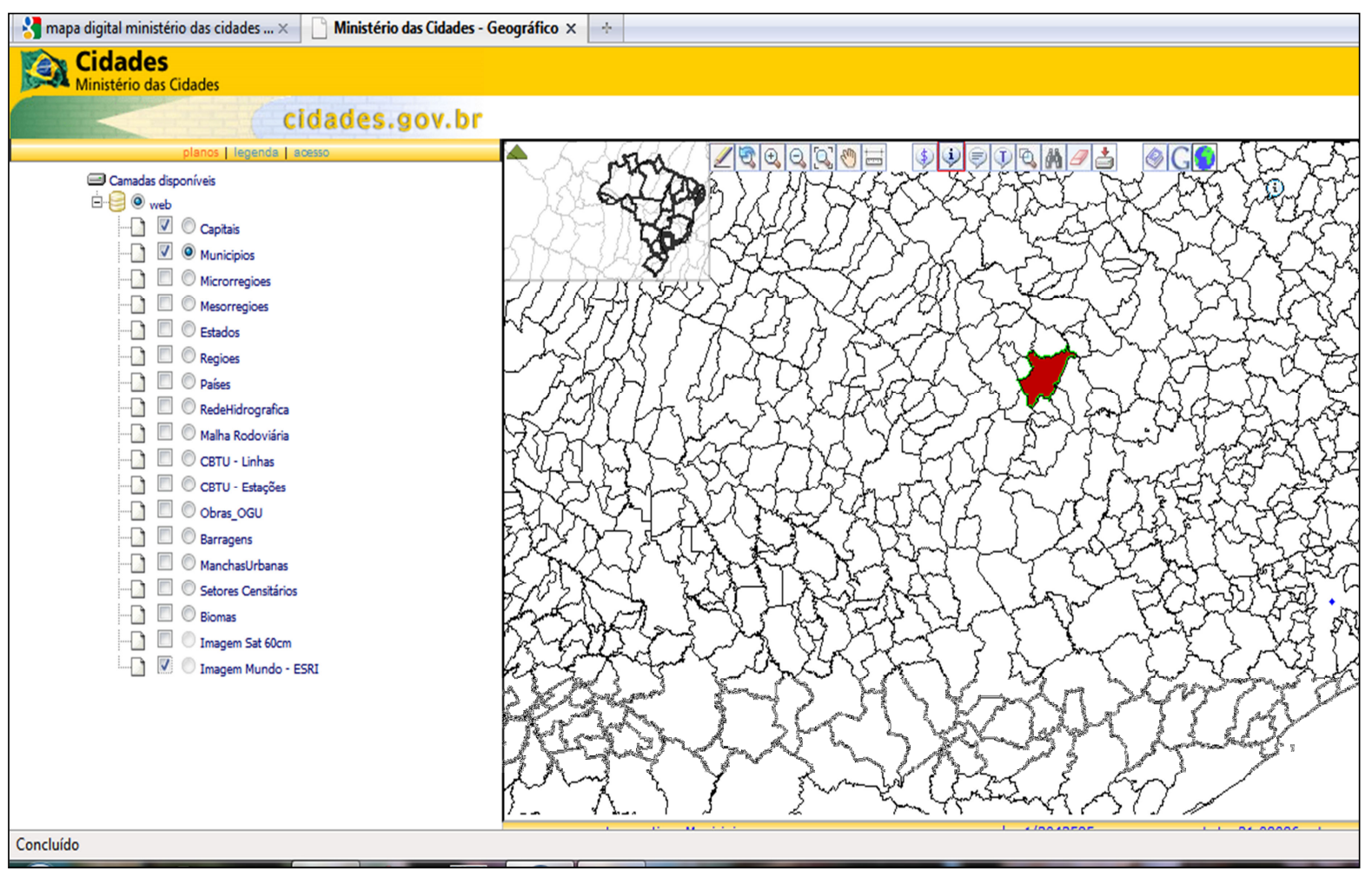

Figura 3.3: Mapa digital do Ministério das Cidades 
Disponibilizado na internet, este sistema possibilitará que os usuários tenham acesso a números, até então, dispersos em diferentes bases de dados geográficos. Apesar de não possibilitar a ligação de tabelas e montagem de outros mapas, nele também será possível a inserção de novos dados municipais, feitos conforme o interesse da própria prefeitura. Este exemplo traz um modelo digital bastante generalizado, mas que fortalece a nova tendência do uso de SIG (aberto) na gestão municipal (MUNDOGEO, 2008).

Quando se utiliza o SIG para finalidades específicas como, planejamento urbano deve-se observar que o software sozinho não pode atender a todas as necessidades de planejamento, porque a geração atual de uso geral dos sistemas disponíveis no mercado não pode facilmente acomodar as necessidades particulares de informação computacional e exibição de planejamento. Assim, o gestores tem que adaptar as ferramentas existentes para atender às suas necessidades, através de linguagens de programação tradicionais que podem ser utilizados para desenvolver a análise espacial e ferramentas de modelação, completamente independentes dos pacotes comerciais (YAAKUP et. al. ,2005).

Uma combinação de comandos sofisticados de SIG e linguagem de programação tradicional podem também ser utilizados para desenvolver modelos analíticos, estreitamente relacionados com conjuntos de ferramentas com todas as funcionalidades de um SIG (KLOSTERMAN, 2001).

O SIG é um dispositivo de visualização e de comunicação, produção de mapas e gráficos que descrevem as condições do passado e do presente e saídas com modelo que sugerem cenários alternativos, que apoiem à tomada de decisão.

\subsection{Uso de SIG na gestão e planejamento urbano}

A superioridade da tecnologia em SIG reside nos seus dados síntese, na simulação geográfica e na capacidade de análise espacial. Portanto, usar a tecnologia e a engenharia de sistemas para auxiliar a gestão urbano tornou-se uma escolha inevitável para o planejamento urbano, por permitir a permite realização da 
automação das informações, a modernização da gestão e da tomada de decisões, baseada em dados científicos (ZHAO, 2009).

Um trabalho desenvolvido na Índia por Priya (1995) aborda o nicho de informações superficiais e subterrâneas com auxílio de SIG sob a ótica da engenharia civil, fornecendo informações geológico-geotécnicas para onde a representação espacial e análise não são separáveis entre ciência e substância, proporcionando a orientação necessária para diversos projetos.

O desktop em SIG, acima desenvolvido, foi personalizado com o propósito de executar a análise e avaliação geotécnica através de quatro etapas:

1. Integração de dados;

2. Visualização e análise dos dados;

3. Planejamento e resumo das características locais; e

4. Apresentação de dados.

Em Kigali capital da Ruanda foi concebido um projeto para fornecer âncoras e para complementar programas urbanos, financiados por vários doadores, com o finalidade de aumentar a sinergia e coerência entre os programas, e também para estimular o aparecimento de transferência e da demanda por iniciativas locais e, ao mesmo tempo contribuir para a boa governança, sustentando parcerias público-privadas, a participação da comunidade e gestão responsável dos recursos (AIBINU, 2001).

O eixo central do projeto foi desenvolver um plano bem articulado a partir do plano de desenvolvimento, para algumas zonas selecionadas sendo estruturado com o desenvolvimento de um plano adequado e estratégias de gestão, dentro dos limites administrativos urbanos, garantindo a sustentabilidade ambiental. Os conceitos que nortearam o projeto foram:

- Elaboração de planos de estrutura e desenvolvimento;

- Desenvolvimento de instrumentos e ferramentas para controlar e implementar os planos;

- Desenvolvimento da capacidade de gestão urbana; e

- Desenvolvimento de ações e projetos imediatos.

Todos estes quatro componentes são relacionados, ligados e interdependentes um do outro, e foram desenvolvidos a partir das seguintes etapas:

i. Inventário; 
ii. Produção da Base Digital;

iii. Pesquisa e trabalho de campo;

iv. Fotografia aérea;

v. Mapeamento Temático; e

vi. Mapa de aptidão (mapeamento de áreas potenciais).

De acordo com Yaakup et. al. (2005) com os problemas urbanos emergentes, as autoridades de planejamento devem aumentar sua capacidade e eficácia na gestão destes problemas. O sistema urbano não pode mais ser tratado em termos de uso da terra simples e conceitos de trânsito.

A concepção do planejador do sistema urbano deve se estender para incluir uma série de variáveis sociais, políticas e econômicas. A mistura de todos os problemas que devem ser resolvidos, cria uma situação em que muitas alternativas devem ser testadas em conjunto, melhoradas e analisadas, por experiência, e pela discussão pública.

Assim, a aplicação do SIG deve ser persistentemente introduzida no planejamento e gestão de áreas urbanas, sabendo-se que o SIG oferece ferramentas que podem contribuir para a compreensão muito mais clara dos problemas de planejamento real, bem como cenários de planejamento normativos para melhorar a qualidade de planejamento e gestão urbana.

Os autores Yaakup et. al (2005) defenderam em seu trabalho na Malásia o uso de um sistema de informações geoespaciais nos planos de desenvolvimento, implementação e monitoramento urbano com utilizando a tecnologia GIS em sua formulação. Na Figura 3.4 é apresentado o fluxograma do modelo desenvolvido em Klang Valley na Malásia. 


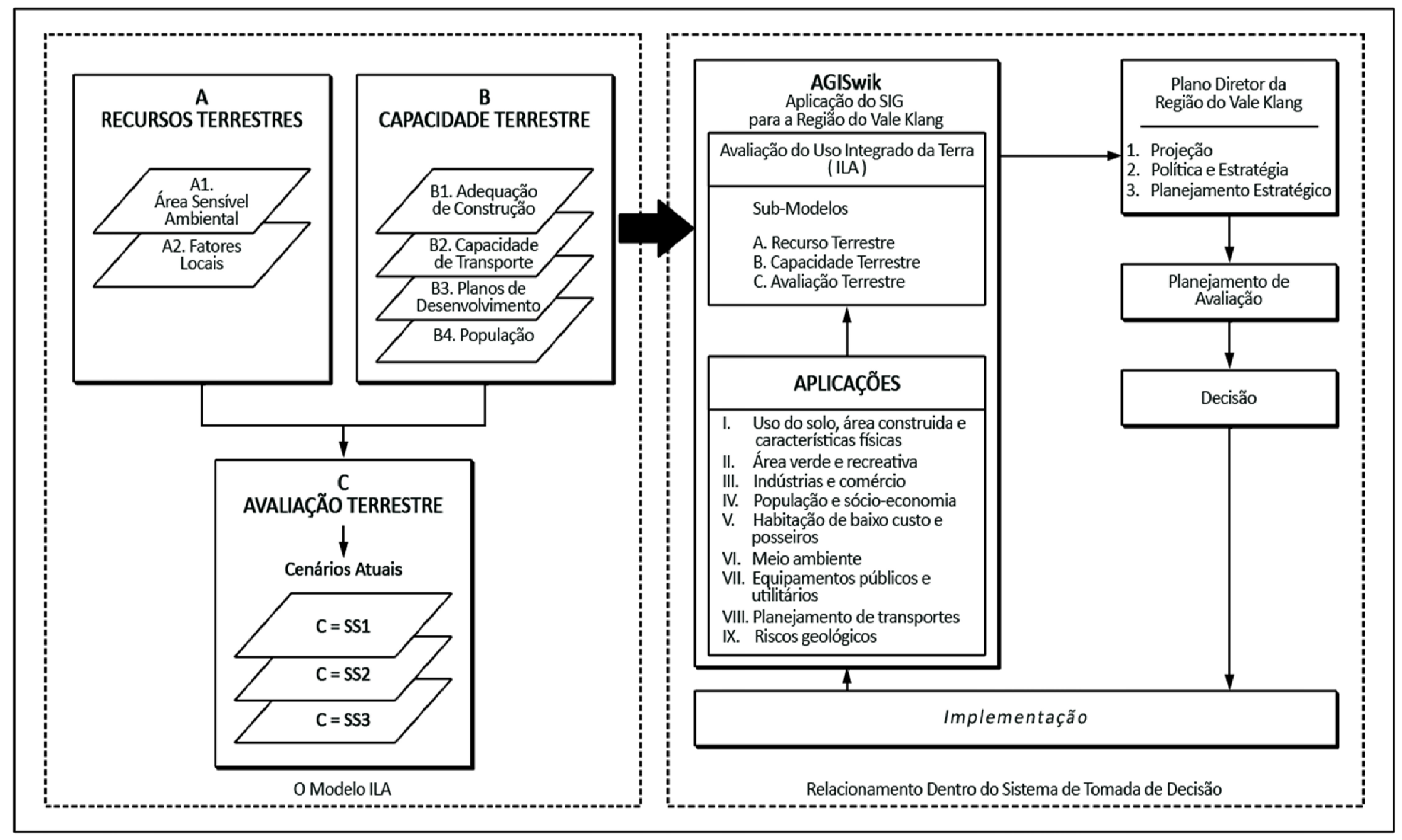

Figura 3.4: Modelo de sista desenvolvido para Klang Valley na Malásia (YAAKUP et. al.2005) 
Burian (2008) afirma que a evolução não é um processo acidental, mas um processo que pode ser gerido e planejado, ele acredita os programas orientados em SIG são utilizados na maior parte das vezes apenas para a criação de saídas (principalmente para mapas impressos), enquanto poderiam ser utilizados no gerenciamento de processos de urbanização e de ordenamento territorial estratégico.

A solução para este sistema foi idealizada a partir de três partes principais:

1. Módulo para a entrada de dados;

2. Módulo para análise de GIS; e

3. Módulo para saídas de dados e visualização de resultados.

Ainda de acordo com BURIAN(2008) o fator mais importante da solução de um software deve ser a possibilidade de entrada interativa e a possibilidade de alterações e modificações, com os dados relevantes para a área estudada, para ser utilizado por multiusuários, ou seja, além dos gestores outros usuários comuns, para tal, foram criadas funções simples e avançadas de acordo com o publico alvo.

O fluxograma da Figura 3.5 apresenta a estruturação do sistema propostos por Burian na Republica Tcheca.

$\mathrm{Na}$ Índia a alta taxa de crescimento da população urbana é uma causa de preocupação entre os planejadores urbanos, há uma necessidade urgente de se adaptar a tecnologia moderna de sensoriamento remoto e SIG, facilitando as analises de dados espaciais, oferecendo possibilidades de gerar várias opções (modelagem), otimizando assim o processo de planejamento.

Em virtude disto o autor ZHAO (2009) desenvolveu um sistema para a gestão e planejamento urbano baseado em SIG, sendo sua estrutura dividida em quatro módulos de função: a referência de planejamento, gestão do resultado, implementação de rastreamento e o sistema de manutenção, descritos no fluxograma da Figura 3.6. 


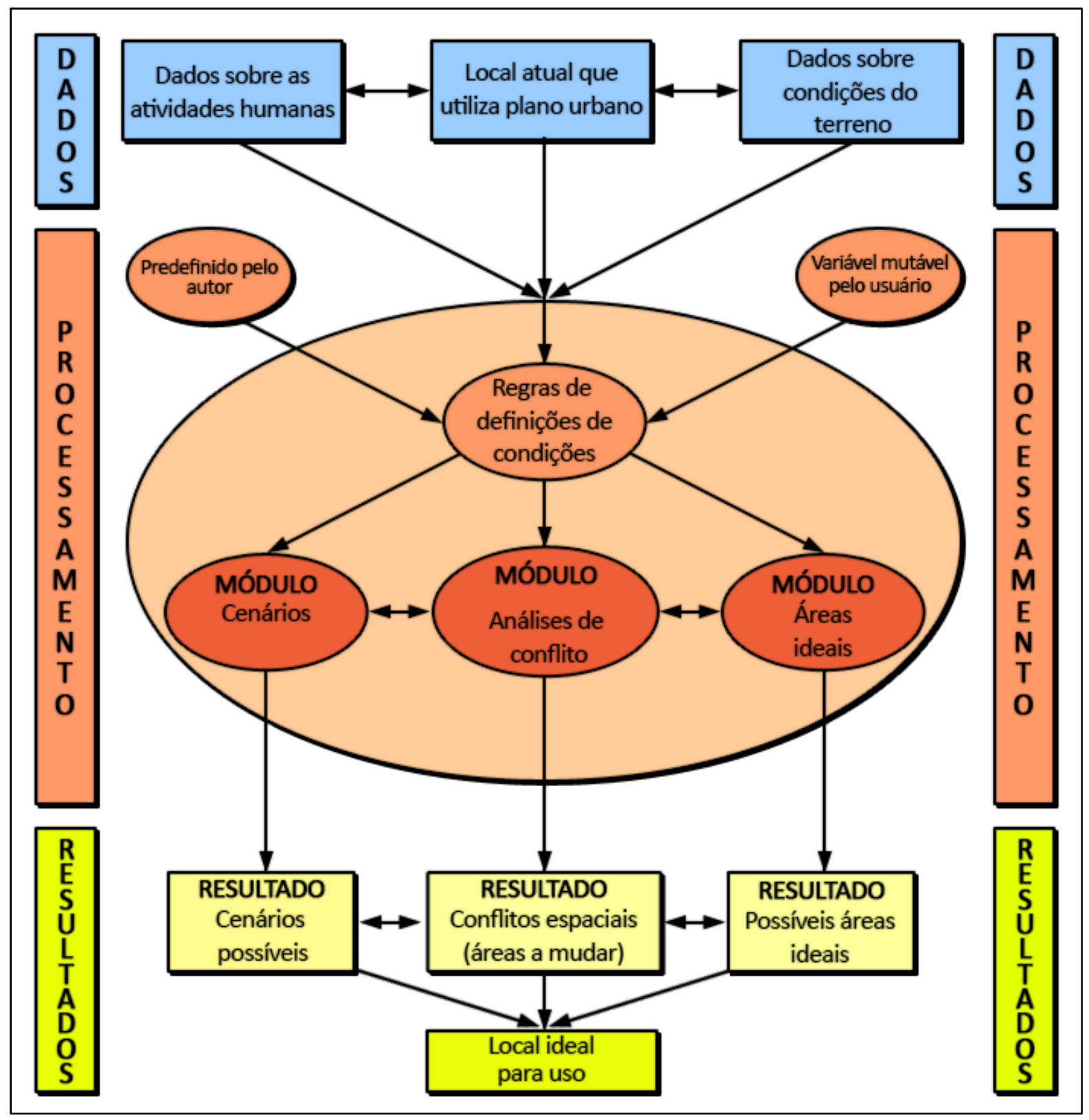

Figura 3.5: Esquema de solução para software ideal (BURIAN, 2008) 


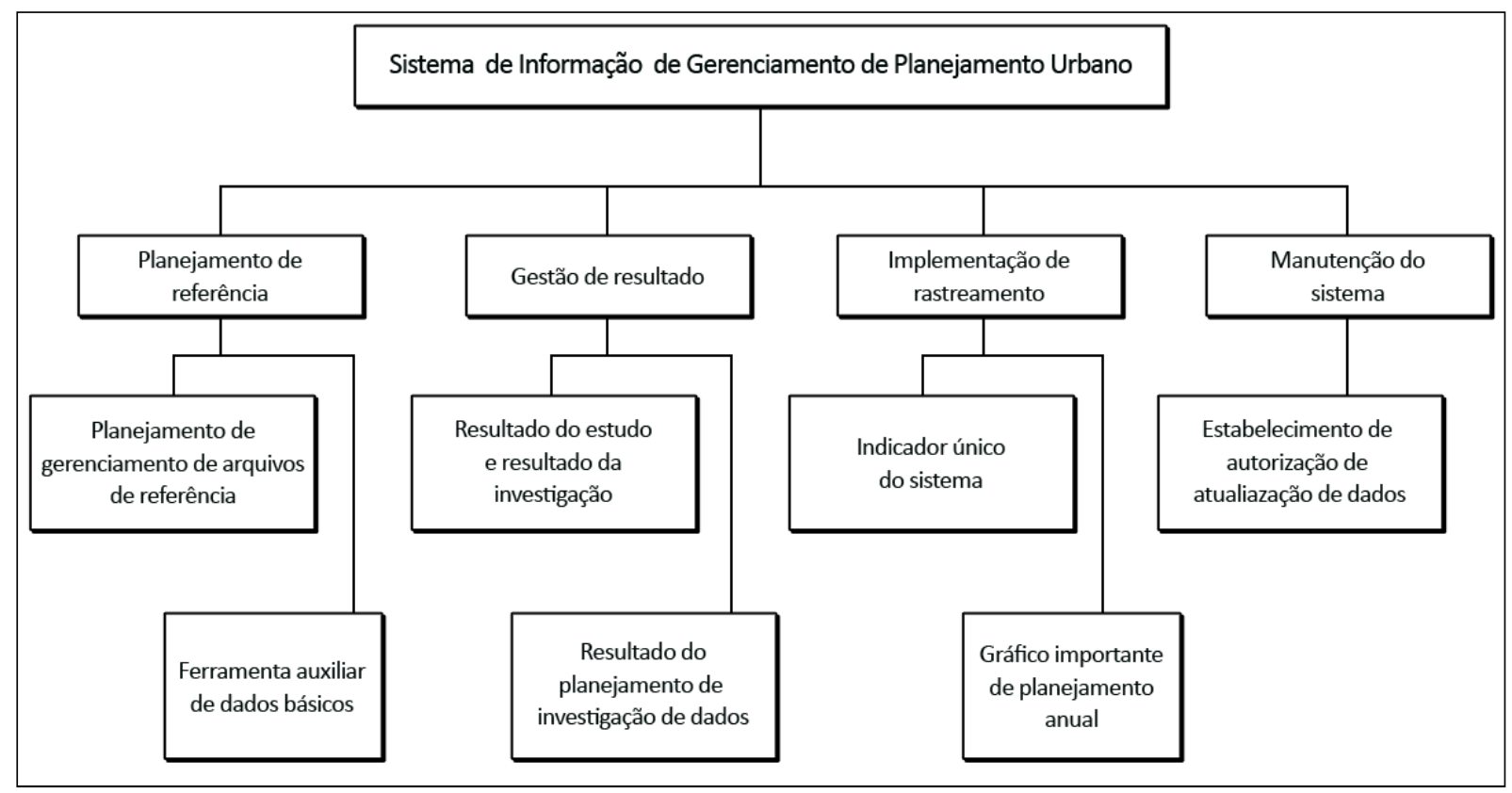

Figura 3.6: Estrutura do sistema proposto por Zhao (2009)

Rai \& Kumra (2011) em seu trabalho na Índia utilizaram dados e imagens coletados e produzidos, para a construção de um sistema a partir de sensoriamento remoto e SIG, baseado no uso da terra atual para delinear o planejamento futuro. Na Figura 3.7 é apresentado um quadro com os usos determinados pelos autores.

De acordo com os objetivos propostos pelos autores o sistema foi capaz de fornecer aos planejadores dados como: localização e extensão das áreas urbanas, a natureza e a distribuição espacial de terra em diferentes categorias dentro das áreas urbanas, as redes de transporte e infraestrutura, dados censitários, indicadores socioeconômicos e o monitoramento das mudanças ao longo do tempo e do espaço.

No município de El Kram na Tunísia, foi desenvolvido um trabalho, que teve como foco a implementação de um "SIG Urbano" abrangente com um banco de dados geográfica avançado permitindo a eficiente abordagem de gestão e planejamento urbano do município (SLAMA \& TURKI, 2011).

Os dados levantando foram provenientes de várias fontes, como mapas cadastrais, mapas topográficos, e imagens do Google Earth e outros 
documentos. Estes conjuntos de dados foram digitalizados, preenchidos e integrados ao banco de dados em SIG.

Tabela 3.2: Classificação do uso do solo urbano proposto por Rai \& Kumra (2011)

\begin{tabular}{|c|c|c|c|}
\hline Nivel I & Nivel II & Nivel IIII & Nivel IV \\
\hline \multirow{40}{*}{ Construido } & Construido (urbano) & Alta densidade residencial & Apartamentos altos \\
\hline & Construido (nural) & Módia densidada residencial & Apartamantos intédios \\
\hline & & Baixa densidado residencial & Apartamantos baixos \\
\hline & & & Casas geminadas \\
\hline & & & Comunldades assentementos \\
\hline & & Industrial & Industria de servigos \\
\hline & & & Indistria lave \\
\hline & & & IIndistrtis nuclear \\
\hline & & & Indúistia posada \\
\hline & & & Perigoso \\
\hline & & Constupe mixóndia & \\
\hline & & Recreativo & Parques / jardins \\
\hline & & & Playwounds \\
\hline & & & Monumenios historicos \\
\hline & & & Sales de cinema \\
\hline & & & Piscinas \\
\hline & & & Principal sallâ de stividadios \\
\hline & & Público e semin público & Eductional \\
\hline & & & Hospeltal \\
\hline & & & Quartés \\
\hline & & & Retigioso \\
\hline & & & Instutuighes govarnamentais \\
\hline & & & Bombe de gasolina \\
\hline & & & Bombolnos \\
\hline & & & Delegadias \\
\hline & & & Outros \\
\hline & & Comunicaches & Comeiss \\
\hline & & & Telogiralo \\
\hline & & & Estacho de radjo a TV \\
\hline & & & Oufros \\
\hline & & Servigos públicos a instalayous & Estaça de fratamento do acura \\
\hline & & & 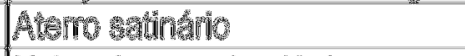 \\
\hline & & & Usina de entergla elétrica \\
\hline & & & Oufros \\
\hline & & & \\
\hline & & Combercial & \\
\hline & & Transporte & Teminal de onibus \\
\hline & & & Estachion ferrovária \\
\hline & & & Aaroporto \\
\hline & & & Oufros \\
\hline & & Temenos baldiss recuperados & Layout \\
\hline
\end{tabular}


O principal resultado foi a construção de sistema de informação em gestão e planejamento urbano, permitindo que muitas operações relacionadas ao cotidiano da gestão pública fossem realizadas.

Ainda foi possível a produção de vários mapas, planos urbanísticos e visualizações tridimensionais facilitando aos funcionários públicos analisar os impactos ou resultados prováveis dos projetos urbanos e do uso do solo nas mudanças de zoneamento propostas, ou ainda visualizar os resultados das iniciativas de crescimento inteligente.

Além disso, melhorias e benefícios significativos foram observados com: um aumento importante da precisão, um aumento de apoio à decisão e tempo, uma otimização do fluxo de trabalho e melhoria de zoneamento. Na Figura 3.7 é apresentada a estrutura do sistema proposto pelos autores.

Em Macaé/RJ, foi desenvolvido um Sistema de Apoio à Decisão (SAD) com o objetivo de auxiliar as atividades gerenciais do município. Foram agrupados diversos dados, sobre temas como: educação, saúde, infraestrutura, indicadores sociais, indicadores urbanos, demografia, etc. (GALANTE \& BRITO, 2003).

Os dados utilizados na construção de territórios digitais podem ser subdivididos em três grandes categorias: dados do meio físico-biótico, dados cadastrais e dados socioeconômicos (Figura 3.8).

O tipo de solo, a geologia, a fauna e flora predominante, a conformação das bacias hidrográficas, o relevo, a drenagem, são características de suma importância dentro da gestão territorial, tais dados devem fazer parte do acervo digital de qualquer prefeitura.

As erosões e as questões associadas não são apenas problemas locais, mas ameaças a bacias hidrográficas inteiras, assim são gerenciadas mais efetivamente quando abordadas desta forma. Recentemente o estudo da degradação provocada por erosões era feito de maneira pontual, não se estabelecia um enfoque integral da situação (ARAUJO et. al. 2008).

Esta perspectiva de análise vem mudando, e atualmente, com o uso dos SIG cria-se um retrato da situação integral, podendo-se reproduzir diversos cenários para a bacia, a partir de um banco de dados que contenha toda modelagem física do local como: uso e tipo do solo, declividade, rede de drenagem, precipitação, cadastro de erosões, etc. 
Segundo Torres (2006) os dados inseridos, num Sistema de Apoio à Decisão (SAD) municipal, dependem tanto das características do município (territoriais, sociais, econômicas, naturais, etc.), quanto da amplitude de informações que se deseja obter. A Figura 3.9 apresenta um fluxograma, com um exemplo, dos tipos de dados que podem ser utilizados em um SAD municipal, ilustrando como estes dados podem ser representados (pontos, linhas ou polígonos).

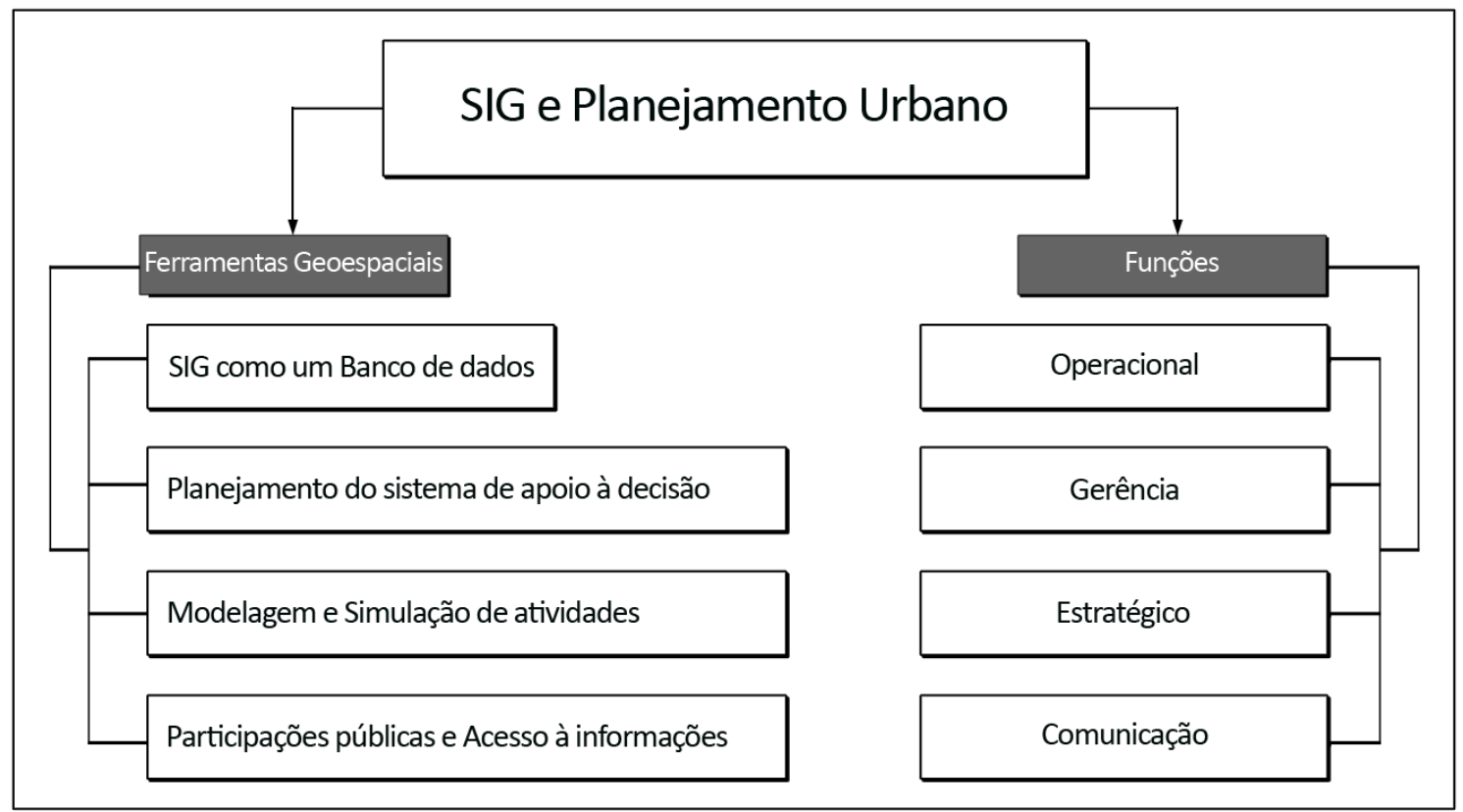

Figura 3.7: Fluxograma ilustrando os processos de concepção do SIG Urbano proposto por SLAMA \& TURKI, 2011

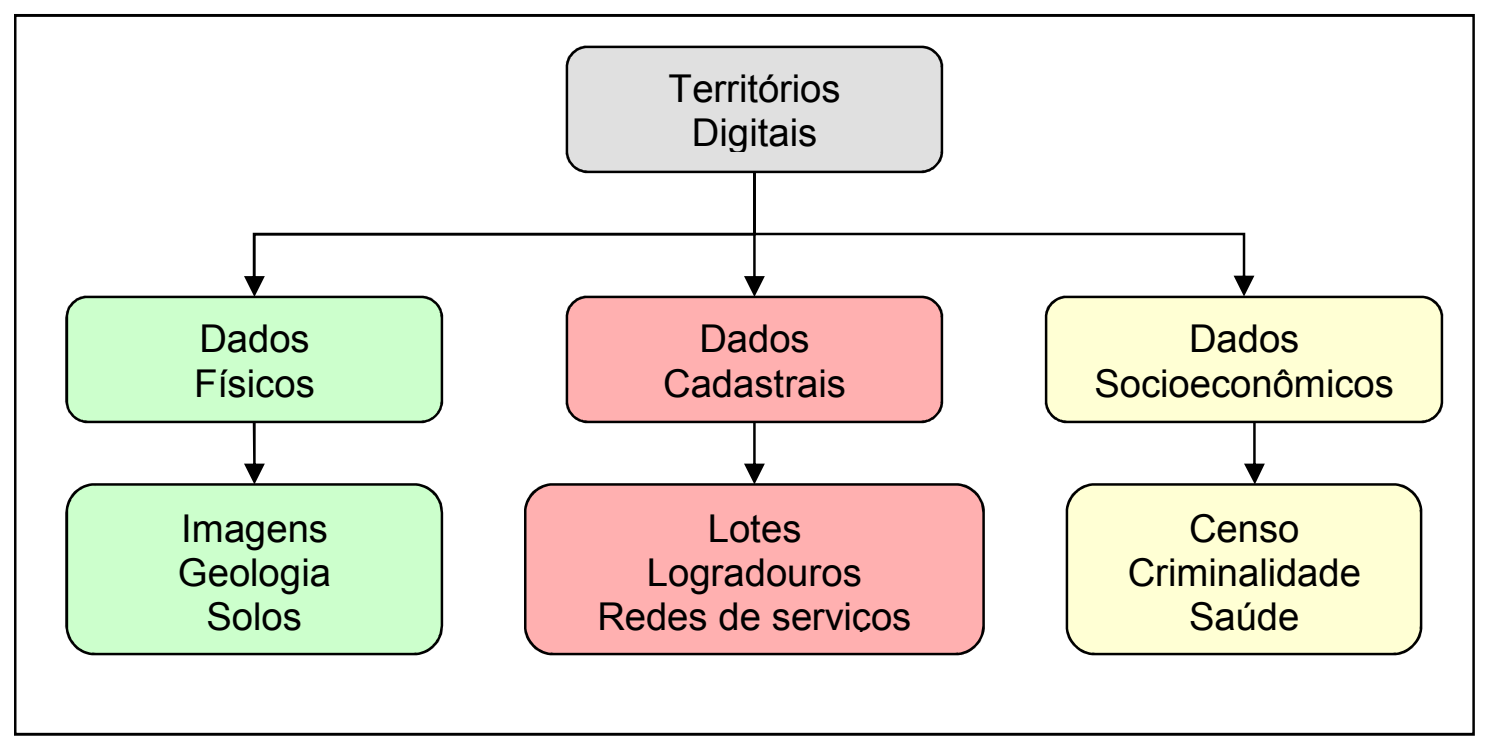

Figura 3.8: Componentes para representação dos territórios digitais urbanos. (ALMEIDA et. al. 2007) 


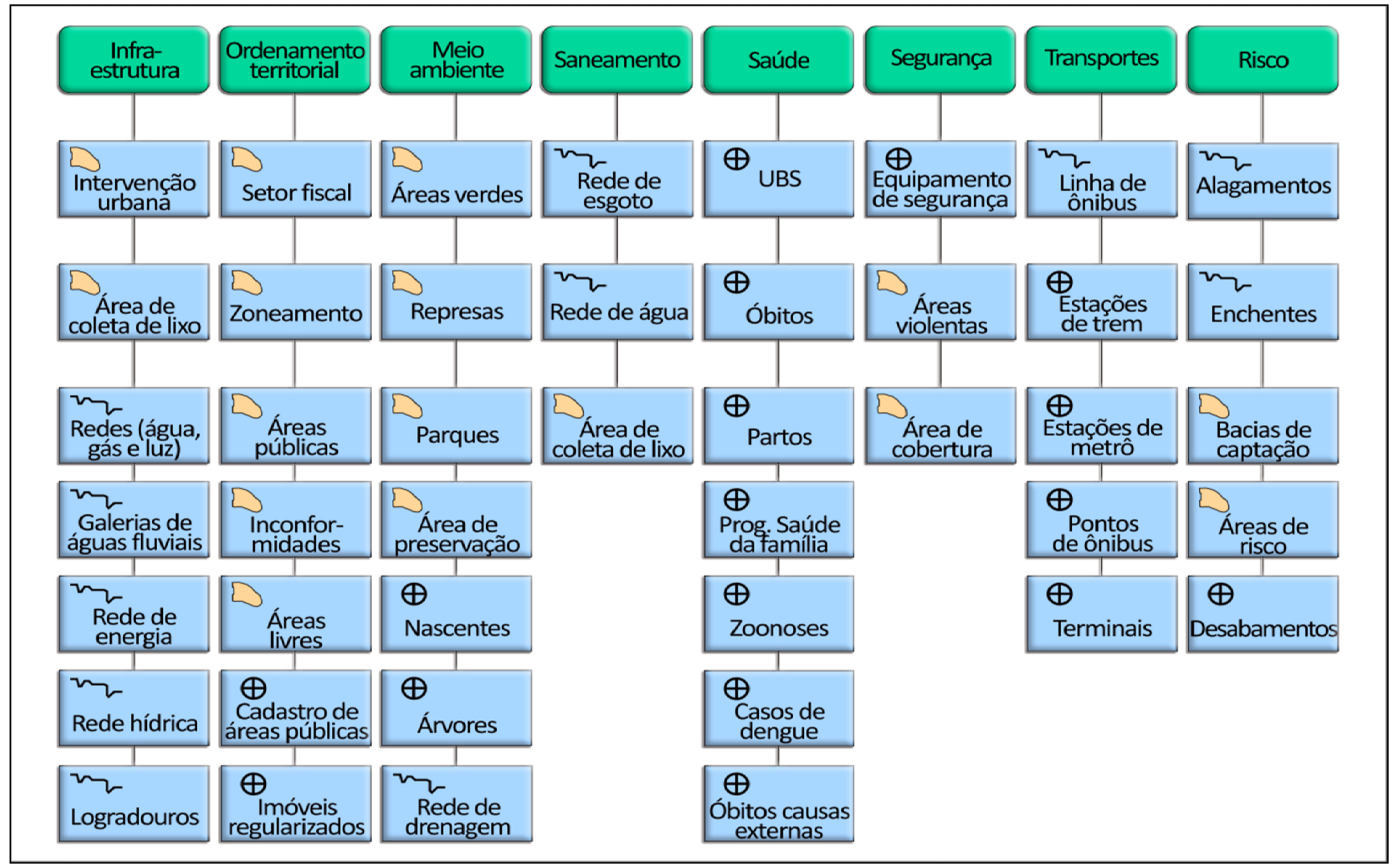

Figura 3.9: Exemplo de informações que podem ser inseridas num Sistema de Apoio à Decisão para SIG. Fonte: TORRES (2006). 


\subsection{Programas de SIG}

Existe uma grande variedade de programas em SIG, a escolha de um deles depende de vários fatores. O ponto de partida é a avaliação dos softwares existentes, que podem ser "livres" ou comercializados.

A funcionalidade de cada programa depende de suas funções, portanto não há como comparar diretamente um software a outro. Os programas de SIG devem ser avaliados estritamente para as necessidades do usuário, considerando os procedimentos, necessidades e contexto do sistema (VOLPI, 2006).

As aplicações em banco de dados têm as funções de: criar, editar, construir e manter todas as informações, e são normalmente mantidas por uma equipe técnica, onde alguns usuários têm a responsabilidade de atualizar os dados, e somente um administrador que controla toda a base.

As outras funções são chamadas de "aplicações do usuário", que na maioria dos programas já estão disponíveis, por exemplo, a visualização de dados e consultas espaciais. Pode-se ainda utilizar softwares que possuam linguagem de programação, sendo possível modificar a estrutura do programa e a interface com o usuário, para desenvolver outras funções desejadas.

O software Arcview GIS 3.2 tem estrutura de visualização dividida em 3 partes principais: Project, View e Theme. O Projeto (Project) é criado e nele são inseridos os views desejados, cada view é composto por themes específicos, os themes são comparáveis aos layers do AutoCAD. A Figura 3.10 mostra um exemplo das 3 hierarquias. Dentro dos themes podem ser adicionados arquivos em formato vetorial ou raster. Segundo Collaço (2002) o dado vetorial é a representação gráfica do mundo real através de sistemas de coordenadas $(x, y)$, assim ele expressa onde determinado fenômeno ocorre, localizando todos os objetos.

Já o dado raster ou matricial refere-se à representação gráfica do mundo real através de pixels (picture element) ou células, com forma poligonal regular, geralmente quadradas ou definidas pelas suas posições em relação às linhas ou colunas de uma malha, representando o que ocorre em todos os locais do terreno. O software permite, portanto a visualização simultânea de diferentes tipos de mapas e dados como mostra a Figura 3.11. 


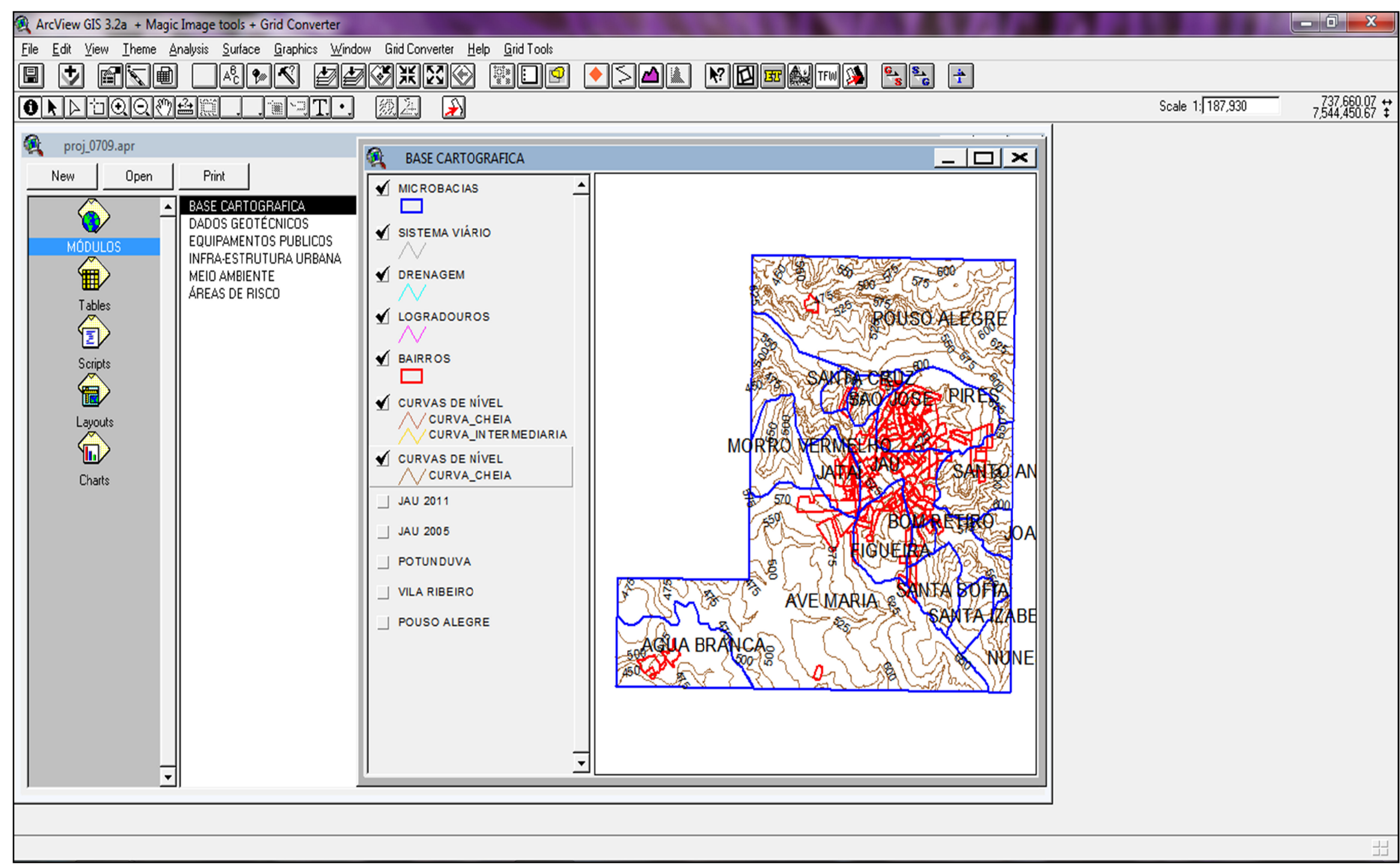

Figura 3.10: Visualização de dados vetoriais e raster 


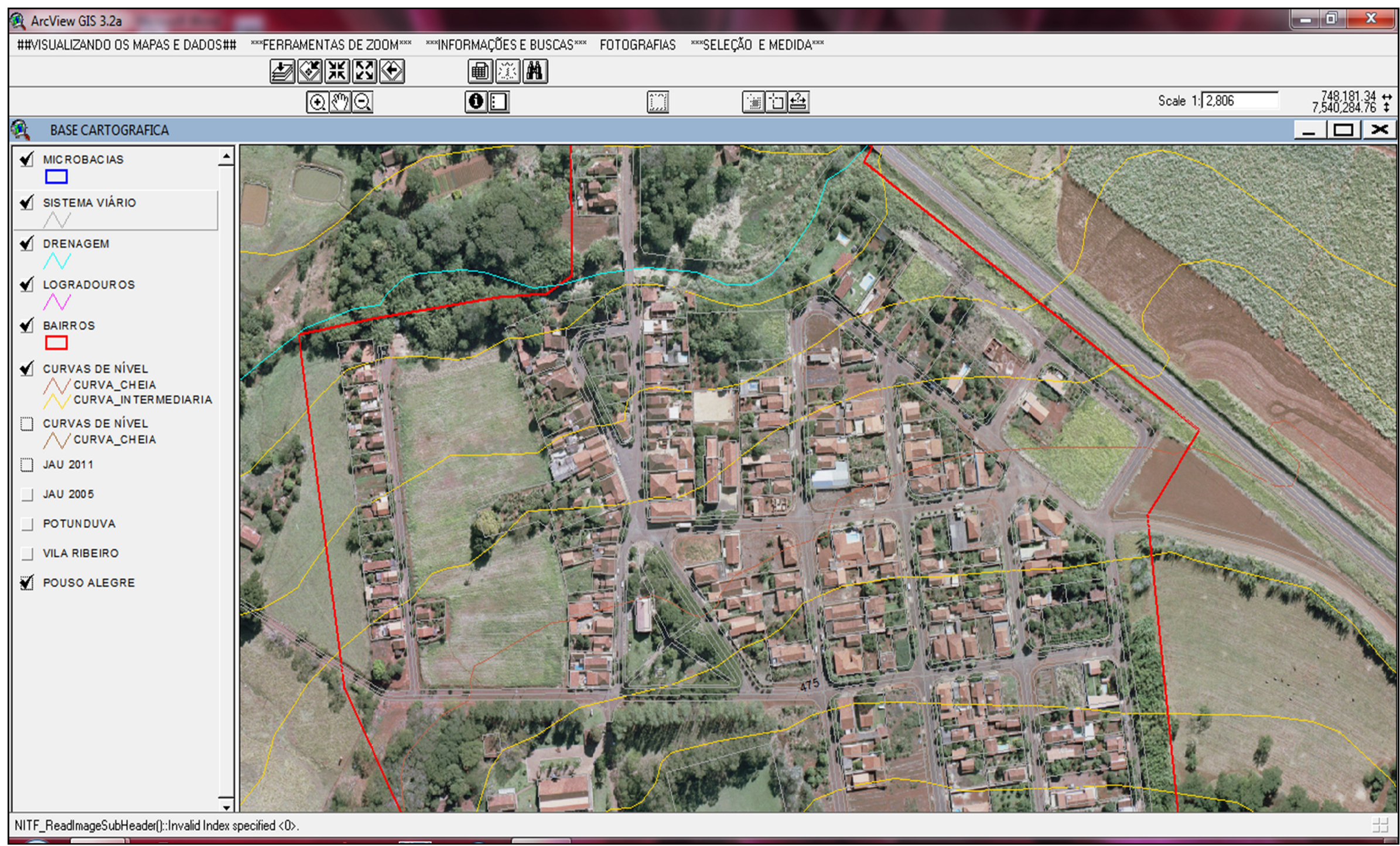

Figura 3.11: Visualização de dados vetoriais e raster 
Linguagem de programação

Existem muitas linguagens de programação que podem ser utilizadas softwares em SIG, no caso do ArcGiew 3.2a é utilizada uma linguagem própria a Avenue.

Segundo ESRI (1997) Avenue é a linguagem de programação orientada para uso de customizações e aplicações em ambiente ArcView. A Figura 3.12 mostra o display de customização utilizado para inserir ou remover ferramentas.

As alterações na estrutura são realizadas com a modificação dos controles existentes e a criação de novas funções, para isto, são usadas caixas de diálogo onde os textos são escritos em linguagem de programação Avenue, sendo chamados de scripts (Figura 3.13).

Há uma variedade de scripts prontos utilizados para acessar funções básicas da interface do programa todos estão disponíveis para o usuário e apresentam grande facilidade para customização do ambiente de trabalho (ETS, 2007).

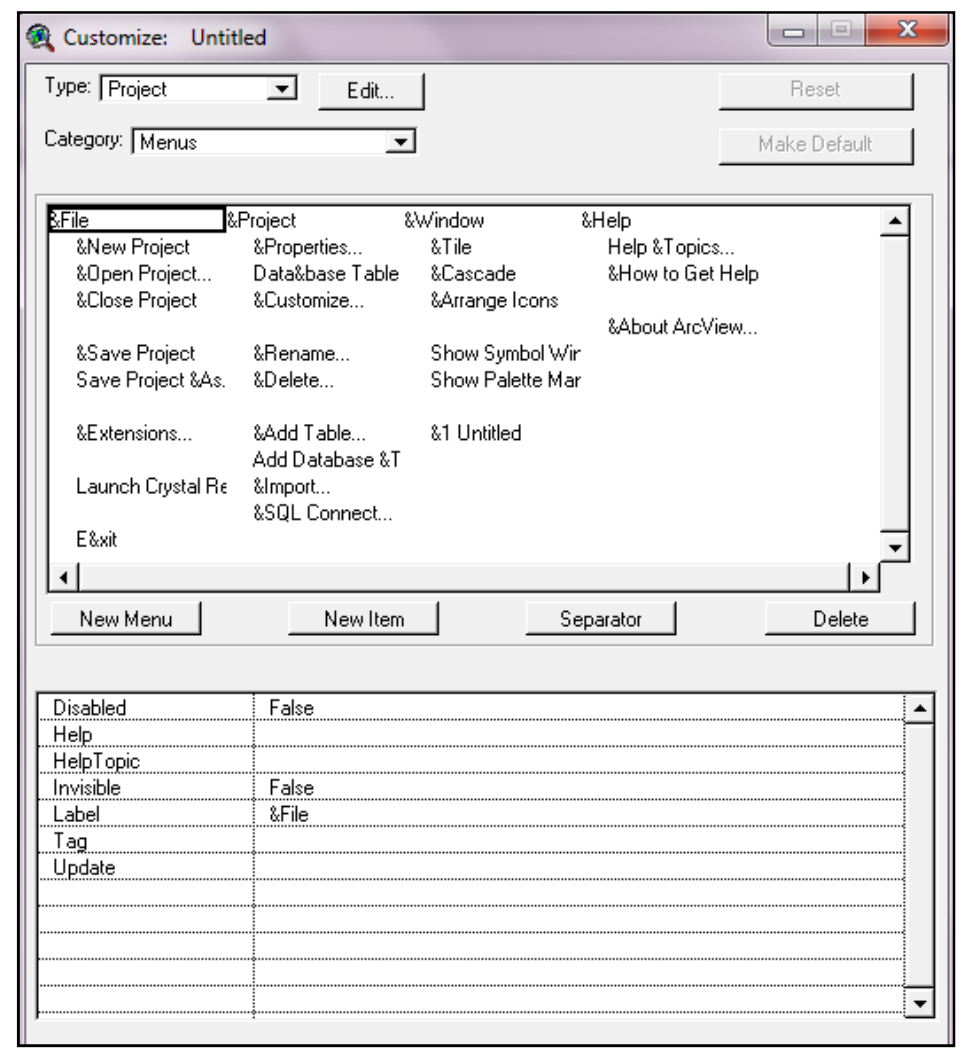

Figura 3.12: Janela de customização 


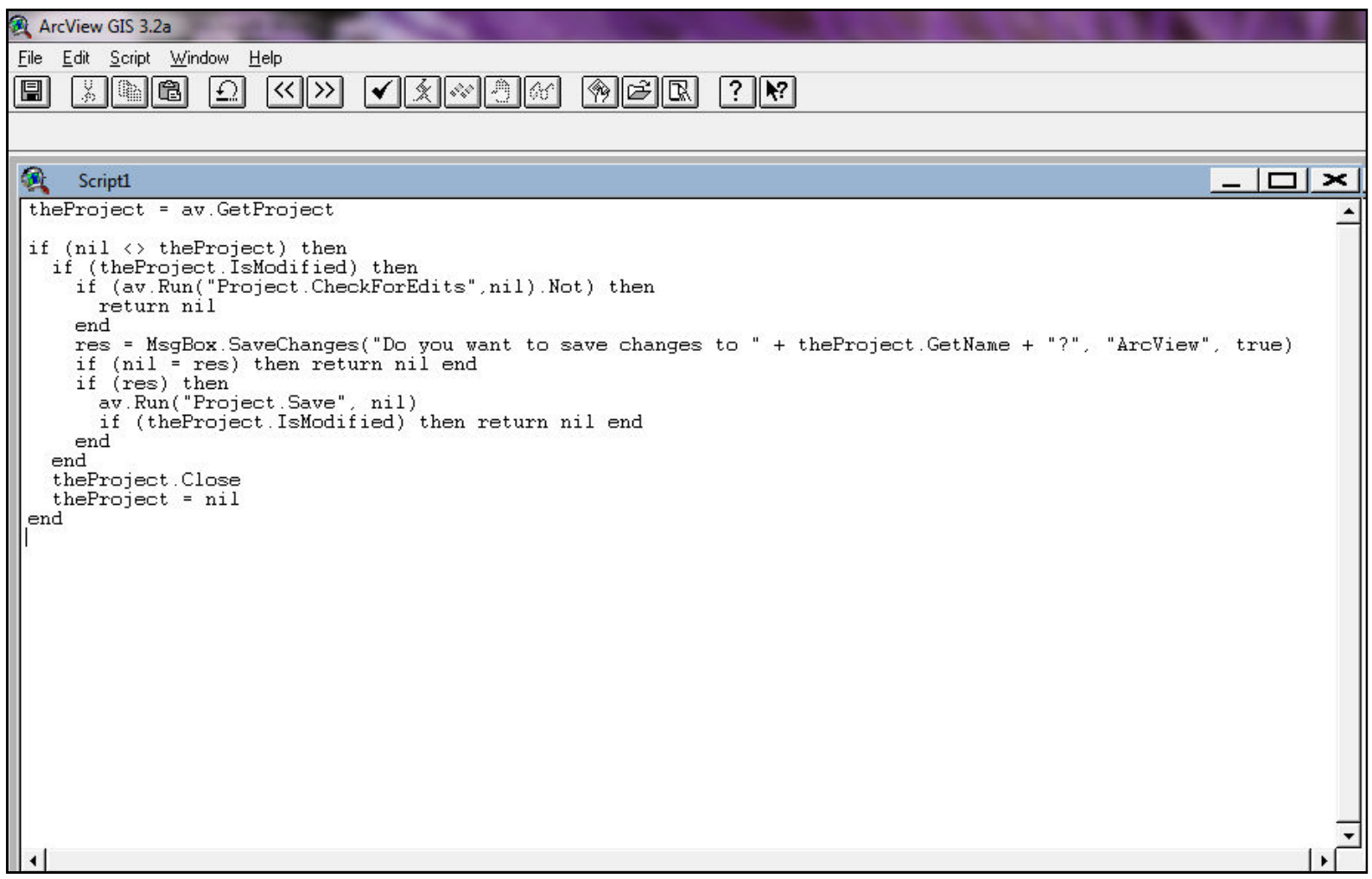

Figura 3.13: Caixa de diálogo para edição de scripts

\subsection{Dados Geotécnicos na Gestão Urbana}

Mathewson \& Font (1974) alertaram para a necessidade de que as informações geológico/geotécnicas cheguem aos planejadores e políticos, de maneira que possam ser aplicadas diretamente à política administrativa de uso e ocupação do solo. Os autores defenderam o conceito de ordenação de mapas, propondo assim que cada ordem de mapa fosse destinada a um tipo de usuário, e que se elaborassem mapas finais de planejamento voltados para gestores públicos (Figura 3.14).

Mendes (2001) afirmou que o conhecimento apropriado da dinâmica da superfície da Terra é fundamental para o planejamento e o gerenciamento efetivos do meio ambiente e dos recursos naturais. Este autor também considera que o mapeamento geotécnico fornece informações essenciais ao planejamento urbano, tais como, a seleção de área adequada à expansão urbana e a contribuição na 
obtenção de um plano urbano e regional que respeite e proteja o ambiente de forma econômica e sustentável.

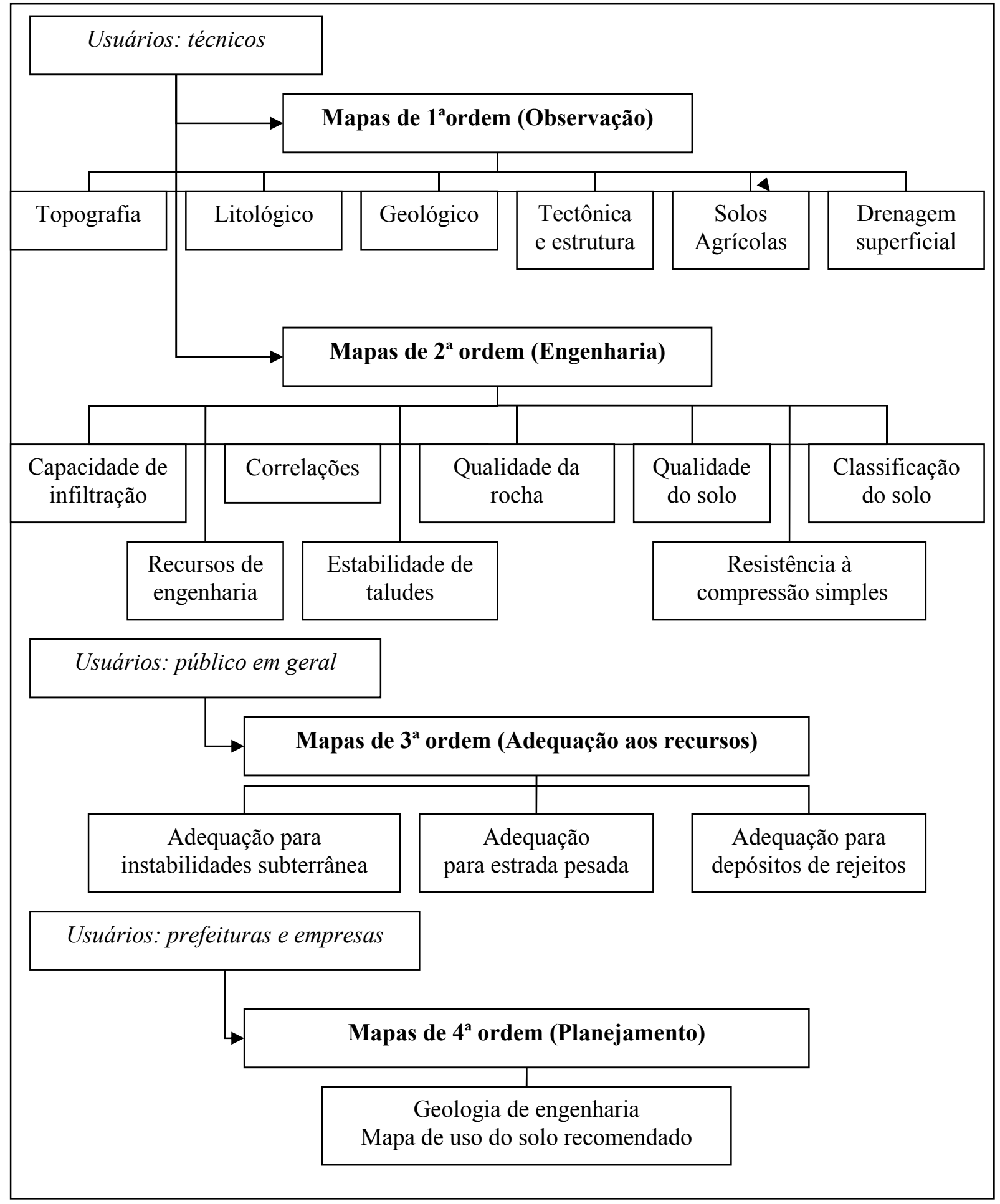

Figura 3.14: Fluxograma da ordenação dos documentos cartográficos relacionados à metodologia de Mathewson e Font (Modificado de ZUQUETTE \& GANDOLFI, 2004). 


\subsubsection{Sondagens a percussão}

As sondagens a percussão ou de simples reconhecimento é um procedimento de investigação geológico-geotécnica para caracterização da cobertura terrosa dos terrenos naturais (OLIVEIRA \& BRITO, 1998). Estas sondagens são as mais freqüentes na engenharia e usualmente executadas para:

- Determinação do perfil geológico das camadas do subsolo;

- Determinação da capacidade de carga das diferentes camadas do subsolo;

- Coleta de amostras das diversas camadas;

- Determinação do nível do lençol freático;

- Determinação da compacidade ou consistência das camadas do subsolo em solos arenosos ou argilosos, respectivamente, e também para a determinação de eventuais linhas de ruptura que possam ocorrer em subsuperfície;

- Determinação da cota de ocorrência do embasamento rochoso se houver.

O uso de dados de sondagem a percussão para o mapeamento geotécnico é bastante eficaz, para Câmara \& Pereira (2005) a grande vantagem de localizar num mapa geotécnico, uma base de dados de sondagens SPT, é a possibilidade de comparação do tipo de solo em que ela se enquadra pelo mapa e suas características indicadas pela sondagem, representando melhor o terreno em superfície e também em profundidade, permitindo uma melhor visualização e interpretação do relevo, podendo-se analisar a ocorrência dos diversos tipos de solo conforme a morfologia do terreno.

\subsubsection{Perfis de Poços Profundos}

Dados de poços de abastecimento de água são de grande valia em estudos de natureza geológica, desde que sejam cadastrados no acervo do Departamento de Águas e Energia Elétrica do Estado de São Paulo (DAEE) órgão que detém a responsabilidade de outorgar o direito ao uso da água. A Figura 3.15 
ilustra um perfil geológico de poço profundo de abastecimento público do município de Jaú.

As informações hidrogeológicas apresentadas ao DAEE podem ser utilizadas para verificação dos aspectos geológicos do local, bem como a descrição litológica de superfície e subsuperfície em seus perfis geológicos que são apresentados no momento da outorga (DAEE, 1982).

O Atlas de Águas subterrâneas do Estado de São Paulo foi elaborado a partir de dados de poços profundos cadastrados pelo DAEE e distribuídos no Estado de São Paulo, foram levantados dados geológicos, disponibilidade hídrica, contaminação, etc.(DAEE, 2005). 


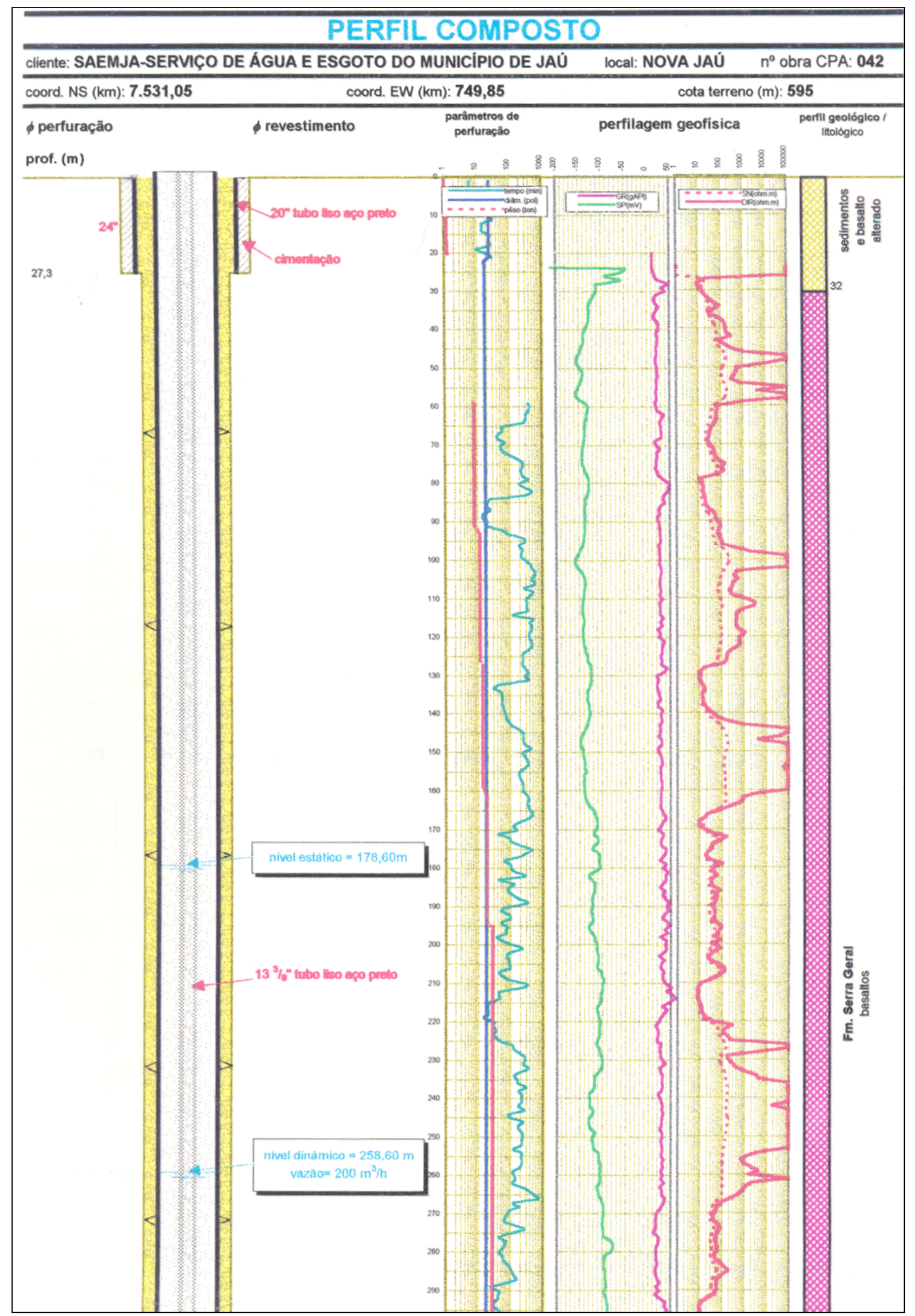

Figura 3.15: Perfil Geológico de Poço de água profundo elaborado através de perfilagem geofísica. 


\subsubsection{Processos de geodinâmica externa}

A perda de solo pela ação da água, do vento, do gelo ou pela força da gravidade é chamada de erosão, constituindo um processo de dinâmica externa relacionada também com fatores condicionantes como: tipo de solo, declividade, precipitação e ações antrópicas. Essas ações podem ser individuais ou não, ou seja, podemos ter um ou mais agentes contribuindo para a perda de solo (Miranda 2005).

A grande maioria dos municípios brasileiros tem problemas com erosões. Estes problemas estão diretamente relacionados ao clima tropical mais diretamente ao fator hidrológico, que promove chuvas torrenciais no verão.

A não consideração destes fatores no processo de planejamento, deflagraram diversos processos erosivos nas áreas urbanas, os tipos de erosões mais comuns encontrados nas áreas urbanas são apresentados na Tabela 3.3.

Tabela 3.3: Tipos de erosões urbanas mais comuns. Adaptado de Miranda (2005) e Oliveira \& Brito (1998)

\begin{tabular}{|l|l|l|}
\hline \multicolumn{2}{|c|}{ Tipo de erosão } & \multicolumn{1}{|c|}{ Características } \\
\hline Erosão laminar & $\begin{array}{l}\text { Feição erosiva oriunda de escoamento difuso das águas, } \\
\text { acarretando a remoção progressiva e relativamente } \\
\text { uniforme dos horizontes superficiais do solo; }\end{array}$ \\
\hline Erosão linear & Sulcos & $\begin{array}{l}\text { Pequenos canais resultantes de escoamentos superficiais } \\
\text { concentrados; }\end{array}$ \\
\cline { 2 - 3 } & Ravinamento & $\begin{array}{l}\text { Feições erosivas resultantes do aprofundamento dos } \\
\text { sulcos provocadas pela concentração escoamento } \\
\text { superficial; }\end{array}$ \\
\cline { 2 - 3 } & Voçoroca & $\begin{array}{l}\text { Erosão desenvolvida por escoamento superficial e fluxos } \\
\text { d'água subsuperficiais, onde se inclui o lençol freático; }\end{array}$ \\
\hline $\begin{array}{l}\text { Movimento } \\
\text { de Massa }\end{array}$ & Escorregamento & $\begin{array}{l}\text { Movimento rápido de massa, de solo ou rocha, bem } \\
\text { definido quanto ao volume, cujo centro de gravidade se } \\
\text { desloca para baixo e para fora do talude (natural ou } \\
\text { aterro). }\end{array}$ \\
\hline
\end{tabular}




\section{4 ÁREA DE ESTUDO}

A área de estudo está localizada no município de Jaú, que possui uma área de $688 \mathrm{~km}^{2}$, com uma altitude média de 522 metros, e com o marco central a Latitude Sul $22^{\circ} 17^{\prime} 44^{\prime \prime}$ e Longitude Oeste $48^{\circ} 33^{\prime} 30^{\prime \prime}$ (Figura 4.1).

A área estudada tem $267,7 \mathrm{~km}^{2}$, abrangendo a área urbana, de expansão do município de Jaú (SP) e três bairros urbanizados, que se encontram distantes do perímetro urbano. Desta área proposta, $70,4 \mathrm{~km}^{2}$ (Figura 4.1) foram analisados por Rodrigues (2008) em dissertação de mestrado, resultando no mapeamento geotécnico focado na gestão urbana e ambiental. 


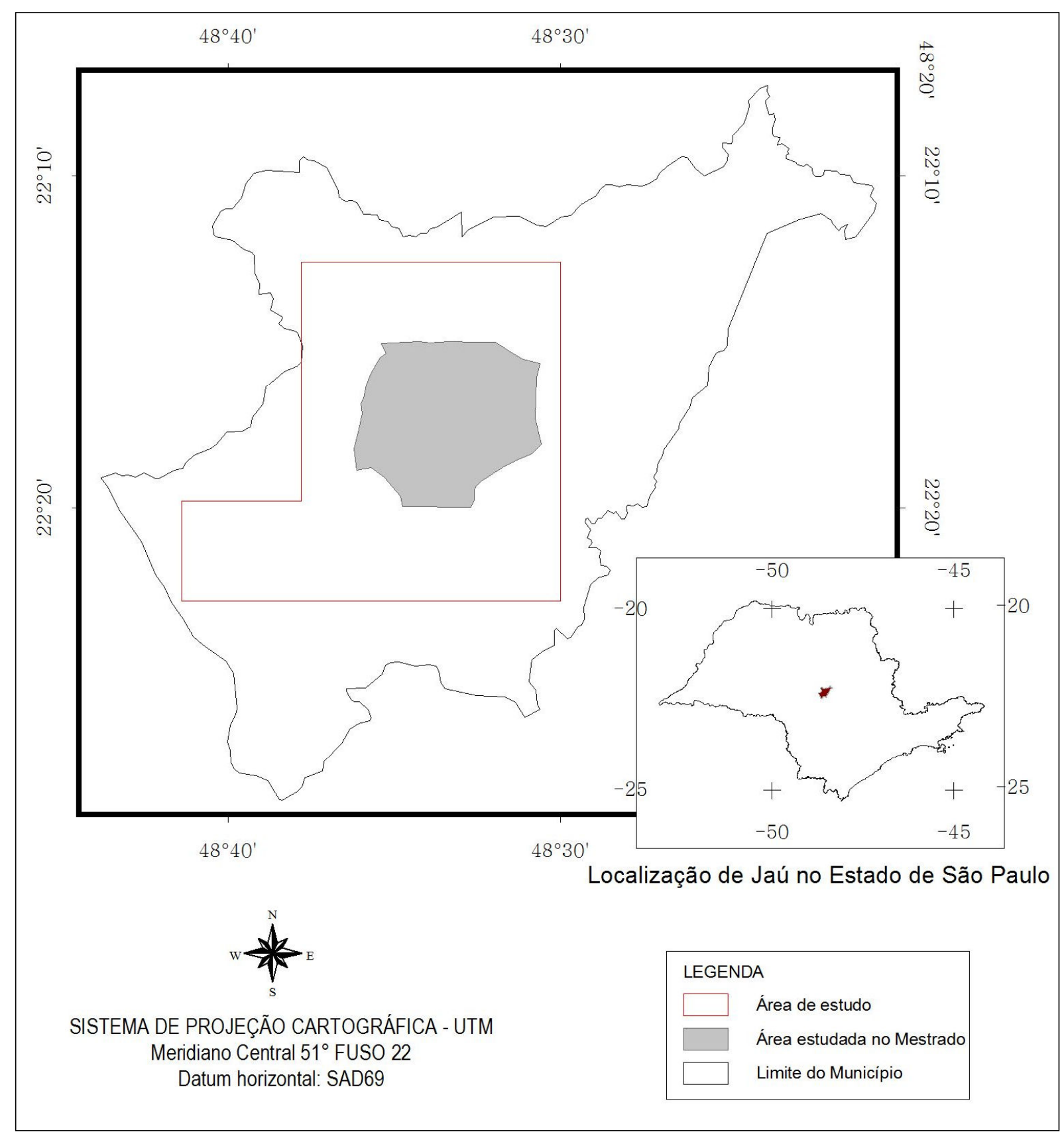

Figura 4.1: Localização da área de estudo no município de Jaú

\subsection{Clima}

De acordo com a classificação de Köppen o clima da cidade é do tipo CWA Mesotérmico, também chamado de Tropical de Altitude, caracterizado por possuir inverso seco e verão chuvoso, com temperatura média superior a $22^{\circ}$. A 
precipitação média anual é de $1.428 \mathrm{~mm}$, com período chuvoso de outubro a março e período seco de abril a setembro, apresentando umidade relativa média do ar de 70\% (PALANCA \& KOFFLER, 1996).

\subsection{Saneamento}

A área urbana do município está, em quase sua totalidade, inserida na bacia do Rio Jaú, manancial que atravessa o centro do perímetro urbano, outras duas bacias ocupam as regiões Norte e Sul do Município, a do Ribeirão Pouso Alegre e a do Ribeirão Ave Maria, respectivamente.

O abastecimento público é proveniente de 5 mananciais superficiais tratados em três Estações de Tratamento de Águas (ETA) e 17 poços tubulares profundos. O município conta com uma Estação de Tratamento de Esgoto (ETE) que iniciou seu funcionamento em 2003, trabalhando em regime de concessão, trata atualmente $100 \%$ do esgoto na área urbana. A cidade não possui aterro, sendo os resíduos encaminhados a um Centro de Gerenciamento de Resíduos em Guatapará.

O município está inserido na UGRHI 13 (Unidade Hidrográfica de Gerenciamento de Recursos Hídricos). Sua maior participação dentro da unidade é no setor agroindustrial, por ter grandes usinas de açúcar e álcool, que acabam sendo a causa de um dos problemas futuros apontados no Relatório Zero de 1999, elevadas demandas de água para o setor. Ainda no mesmo relatório são citados problemas quanto ao rebaixamento do nível do lençol freático e a contaminação das águas subterrâneas (SAO PAULO, 2004).

\subsection{Impactos Negativos}

O município de Jaú apresenta, em sua área urbana, problemas relativos a processos erosivos e a enchentes. Ambos são intimamente relacionados 
à precipitação intensa que ocorrem durante o verão, todos os anos novos processos erosivos são desencadeados e surgem novos pontos com problemas de inundação.

\subsection{Geoprocessamento}

O município de Jaú utiliza um programa desenvolvido por uma empresa particular, denominado GEOFACIL, é um software baseado em SIG, com um banco de dados formado por um mosaico digital (fotografia aérea) e dados cadastrais, onde os usuários podem realizar buscas por ruas ou por lotes.

Neste sistema o lote constitui uma ontologia que representa inúmeros dados, sendo utilizados pelos setores de cadastro e fiscalização, principalmente para o cálculo do IPTU (imposto predial e territorial urbano). As informações que constam neste bando de dados só podem ser alteradas pela empresa contratada e ele é atualizado via internet diariamente. Somente os computadores da prefeitura podem acessar o programa.

\subsection{Legislação}

O Plano Diretor do município de Jaú foi instituído em 10 de outubro de 2006 pela Lei Complementar $n^{\circ} 277$ (JAHU,2006), no ano seguinte foi elaborada a Lei Complementar de $\mathrm{n}^{\circ} 298$ que trata do Zoneamento (JAHU,2007).

A Lei de Zoneamento foi muito questionada por apresentar parâmetros construtivos inadequados para área urbana já existente. Por este motivo muitos projetos ficaram paralisados, por não se adequarem a legislação.

Em 2008 iniciou-se um processo de revisão do Plano Diretor finalizado em 2012, uma equipe formada por professores e alunos da Universidade Estadual Paulista de Bauru (UNESP) e técnicos da Secretaria de Planejamento da prefeitura municipal ficou responsável pelas alterações discutidas em audiências públicas. 
A lei deu maior flexibilidade na adequação da cidade consolidada e em contraponto maior rigidez no que diz respeito à sustentabilidade ambiental.

O novo desenho urbano dividiu a cidade em Unidades de Paisagem (UDP), estas divisões têm como objetivo a organização do espaço em áreas geograficamente homogêneas onde os equipamentos públicos devem ser distribuídos e a mobilidade ocorra de maneira ordenada entre as UDP e também ao centro histórico.

Este fluxo será organizado por um anel urbano composto de ruas e avenidas que atravessam todas as UDP e por corredores de entrada e saída da cidade que tenham o anel urbano como vértice. Estrategicamente foram locados quatro polinúcleos no trajeto do anel viário, onde haverá maior flexibilidade construtiva no que diz respeito ao adensamento e ao uso do solo.

Estas medidas visam à descentralização das atividades potencialmente geradores de tráfego, amenizando os problemas de trânsito da área central e retomando o caráter histórico deste centro que possui cerca de 400 imóveis tombados pelo Conselho de Preservação do Patrimônio Cultural do Município de Jaú (CONPPAC)

O novo zoneamento proposto tem por objetivo proteger os mananciais ainda não ocupados, e adequar às áreas já consolidadas, constituindo parâmetros construtivos reais e possíveis de serem utilizados.

Cada zona foi trabalhada separadamente testando-se os recuos, os coeficientes de aproveitamento, as taxas de ocupação e permeabilidade, para cada tamanho de lote, criando tipologias que retratam o cenário urbano de forma mais real, o que no zoneamento anterior não foi alcançado.

A nova Lei de Zoneamento recebeu o ${ }^{\circ} 443$ e passou a vigorar em 07 de dezembro de 2012, após sua aprovação pela câmara municipal (JAHU, 2012). 


\section{MÉTODO E MATERIAIS}

A pesquisa é um procedimento reflexivo, sistemático e crítico que permite descobrir novos fatos ou dados, soluções ou leis, em qualquer área de conhecimento. Dessa forma, a pesquisa é uma atividade voltada para a solução de problemas por meio dos processos do método científico (RAMPAZZO, 2002).

De acordo com Vargas (2011) a tecnologia deve ser entendida como a utilização de conhecimentos científicos para satisfazer as autênticas necessidades materiais de um povo, sendo portanto, parte de sua cultura e não pode ser considerada como mera mercadoria, é algo que se adquire vivendo, aprendendo, pesquisando, interrogando e discutindo.

O foco da pesquisa tecnológica é a aplicação dos conhecimentos para realização de ações específicas, definidas conforme as necessidades estabelecidas.

Neste contexto, o mapeamento geotécnico tem sido usado em todo o mundo como ferramenta que auxilia na definição e na fiscalização da ocupação urbana de maneira ajustada tecnicamente, respeitando as áreas de interesse ambiental e as condições necessárias para que a população desfrute-as sem alterar suas condições básicas de vida (RODRIGUES, 2008). 
A abordagem metodológica geral adotada para elaboração do sistema de apoio a gestão urbana foi baseada no desenvolvimento de um projeto estruturado em SIG de qualquer natureza proposto por ESRI (1996).

Com base nestes fundamentos, nas hipóteses de trabalho e nos objetivos propostos, a pesquisa de doutorado foi estruturada em cinco grandes etapas descritas a seguir:

1. Revisão Bibliográfica;

2. Estruturação do Sistema;

3. Aplicação e Validação do Sistema em Jaú;

4. Análise dos Resultados;

5. Conclusões e Redação da Tese.

Os itens seguintes abordaram cada uma destas etapas.

\subsection{Revisão Bibliográfica}

A revisão bibliográfica deste trabalho permeou várias áreas apresentando as definições e as manifestações literárias de diversos autores.

Os principais temas abordados na fundamentação teórica foram: gestão e planejamento urbano, integração de dados (principalmente geotécnicos) e Sistemas de Informações Geográficas. Buscou-se apresentar experiências brasileiras e mundiais relacionadas com o uso do SIG em gestão urbana.

\subsection{Estruturação do Sistema}

O sistema foi estruturado a partir das etapas de estruturação de um projeto em SIG (ESRI,1996), descritos a seguir: 
1. Definição dos objetivos e funções do sistema (funções, usuários potenciais, tipos de consulta e saídas);

2. Estruturação da base de dados;

3. Definição das análises, ferramentas e produtos;

4. Definição da forma de apresentação dos resultados;

\subsubsection{Definição dos objetivos do Sistema}

Acompanhando a dinâmica dos profissionais envolvidos com a gestão e planejamento urbano no município de Jaú foi possível definir os principais objetivos do sistema de apoio a gestão urbana.

Estes objetivos são a otimização das buscas por informações, análise espacial e o embasamento técnico para as avaliações da gestão urbana, retratando as necessidades dos gestores em diversas rotinas de trabalho.

\subsubsection{Estruturação da base de dados}

A estruturação da base de dados iniciou-se pelo levantamento dos dados e informações existentes sobre a área de estudo. A Tabela 5.1 descreve os dados levantados para esta pesquisa.

Os dados levantados foram produzidos por Rodrigues (2008) e tratam de uma área de $70,4 \mathrm{Km}^{2}$.

A área de estudo desta pesquisa é de $267,6 \mathrm{Km}^{2}$, para tal área foram levantados outras informações e produzidos novos mapas para compor a base de dados do sistema proposto, os próximos itens descrevem a metodologia de elaboração destes produtos. 
Tabela 5.1: Descrição dos dados levantados

\begin{tabular}{lcc}
\hline Informação & Geometria & Quantidade \\
\hline Curvas de nível (5m) & linha & $70 \mathrm{~km}^{2}$ \\
Drenagem & linha & $70 \mathrm{~km}^{2}$ \\
Geologia & poligono & $70 \mathrm{~km}^{2}$ \\
Materiais inconsolidados & poligonos & $70 \mathrm{~km}^{2}$ \\
Delimitação de processos erosivos & linhas e poligonos & $70 \mathrm{~km}^{2}$ \\
Perfis de poços profundos & pontos & 21 \\
Perfis de poços de observação & pontos & 19 \\
Sondagens à percussão SPT & pontos & 135 \\
Afloramentos rochosos & pontos & 6 \\
Locais de amostragem & pontos & 6 \\
Sistema viário & linhas & $70 \mathrm{~km}^{2}$ \\
\hline
\end{tabular}

\subsubsection{Base Cartográfica}

A área digitalizada foi de $197,7 \mathrm{~km}^{2}$ complementando a área produzida por Rodrigues (2008), onde foram utilizadas as cartas do IGC de 1980 na escala 1:10.000, nove cartas no total. A Figura 5.1 ilustra a articulação das 9 folhas do IGC.

A base cartográfica foi constituída pelos temas apresentados na Tabela 5.2, este dados foram gerados na escala de trabalho 1:10.000.

Foi realizada a divisão por Microbacias, a partir dos dados topográficos e hidrológicos determinando os divisores de água. A configuração final do mapa resultou em uma subdivisão da bacia do Rio Jaú, por se tratar da bacia predominante na área urbana e por apresentar maior quantidade de dados disponíveis.

Já as bacias do Ribeirão Pouso Alegre e Ribeirão Ave Maria, não foram subdivididas por se tratarem de áreas rurais e ter menor quantidade de dados.

Além dos 8 temas vetoriais foram anexadas a base cartográfica dois tipos de imagens raster, a primeira do ano de 2005 resultado de um fotomosaico produzido a partir de fotografias aéreas (fornecido pela Prefeitura de Jaú) e a 
segunda, outro fotomosaico produzido através de imagens do Google de 2010 (fornecido pela Fatec-Jahu).

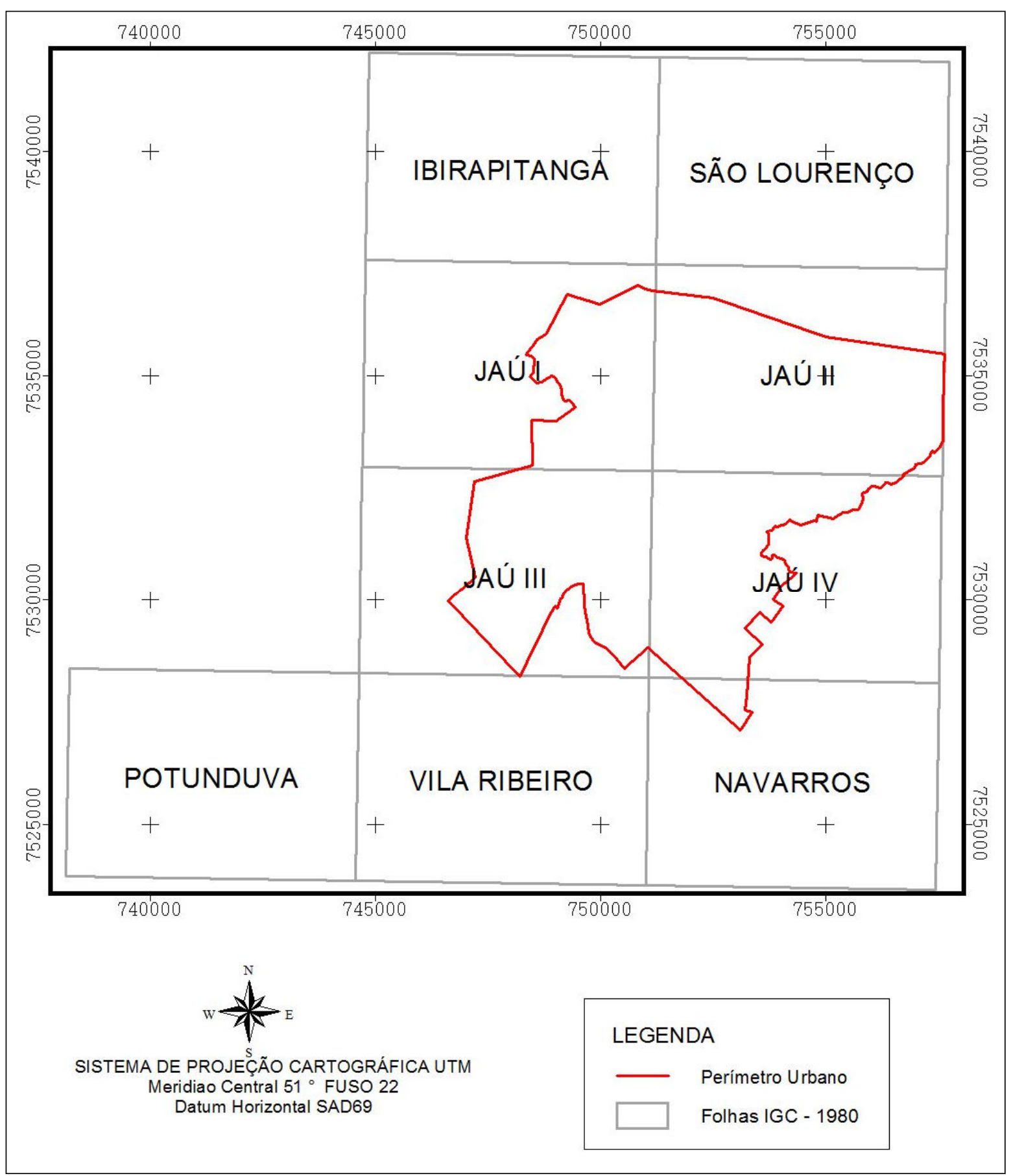

Figura 5.1: Articulação das Folhas do IGC 
Tabela 5.2: Temas que formam a base cartográfica

\begin{tabular}{|c|c|c|c|}
\hline Tema & Geometria & Fonte & Observações \\
\hline Curvas de nível $(5 \mathrm{~m})$ & Linhas & IGC - 1980 & Digitalizado \\
\hline Drenagem & Linhas & IGC - 1980 & $\begin{array}{l}\text { Digitalizado e conferido em } \\
\text { campo }\end{array}$ \\
\hline Microbacias & Polígonos & $\begin{array}{l}\text { Delimitadas a partir } \\
\text { da base topográfica }\end{array}$ & Interpretado \\
\hline Perímetro Urbano & Polígono & PM-Jaú & Cedido PM-Jaú \\
\hline Sistema viário & Linhas & $\begin{array}{c}\text { PM-Jaú, IGC - } 1980 \text { e } \\
\text { Fotomosaico }\end{array}$ & $\begin{array}{c}\text { Ruas cedidos pela } \\
\text { PM-Jaú e rodovias e } \\
\text { estradas rurais digitalizados }\end{array}$ \\
\hline Logradouros & Linhas & PM-Jaú & $\begin{array}{l}\text { Cedidos pela } \\
\text { PM-Jaú }\end{array}$ \\
\hline Lotes & Polígonos & PM-Jaú & $\begin{array}{l}\text { Ruas cedidos pela } \\
\text { PM-Jaú }\end{array}$ \\
\hline Bairros & Polígonos & PM-Jaú & $\begin{array}{l}\text { Produzidos através de } \\
\text { revisão de documentos da } \\
\text { PM Jaú }\end{array}$ \\
\hline
\end{tabular}

PM - Jaú: Prefeitura Municipal de Jaú

IGC - Instituto Geográfico Cartográfico

\subsubsection{MDT}

O MDT foi elaborado a partir da base topográfica 1:10.000, utilizandose o modulo topogrid do Arcinfo 7.1, que considera as curvas de nível, os pontos cotados, as linhas drenagem e o seu sentido de fluxo. Adotou-se um grid de $5 \mathrm{~m}$ para elaboração do MDT. Posteriormente este grid foi convertido para o formato TIN (Trinagular Irregular Network) dentro do Arcview 3.2a. 


\subsubsection{Mapa de Declividade e Mapa Hipsométrico}

O Mapa de Declividade foi elaborado a partir do MDT no formato TIN, utilizando a função derive slope, criando-se uma grade numérica (grid) de declividade em graus, com células de 5 por 5 metros, que posteriormente foi classificada em quatro intervalos de classes de declividades expressas em percentagem.

Estas quatro classes foram estabelecidas considerando-se as restrições potenciais ao parcelamento dos solos, conforme Tabela 5.3 baseada na proposta do IPT (1991).

O mapa hipsométrico foi elaborado a partir do fatiamento do MDT em 6 classes, sendo cada classe com intervalo de 40 metros.

Tabela 5.3: Restrições de declividade quanto ao uso de solo urbano (Adaptada de RODRIGUES, 2008)

\begin{tabular}{|c|c|}
\hline $\begin{array}{l}\text { Declividade } \\
(\%)\end{array}$ & Restrições ao uso do solo \\
\hline $0-6$ & Poucas restrições \\
\hline $6-15$ & Intensificação dos processos erosivos pluviais. \\
\hline $15-30$ & $\begin{array}{l}\text { Maior dificuldade para serviços de terraplanagem, implantação do sistema } \\
\text { viário, drenagem, etc. }\end{array}$ \\
\hline$>30$ & $\begin{array}{l}\text { Intensificação dos movimentos de massa e a ocupação está sujeita às } \\
\text { restrições da Lei Lehman* }\end{array}$ \\
\hline
\end{tabular}

* Lei Federal 6.766/79 (BRASIL,1979)

\subsubsection{Mapa de Unidades Geológicas}

O Mapa de Unidades Geológicas foi produzido a partir de do Mapa Geológico do Estado de São Paulo, folha Bauru desenvolvido pelo DAEE (1982) e do Mapa Geológico do Estado de São Paulo desenvolvido pelo IPT (1981), constantes na Tabela 5.4. Os contatos geológicos foram aprimorados com os 
resultados dos ensaios de granulometria e com visitas a campo, já que os dois mapas utilizados como base são de escalas regionais.

\subsubsection{Mapa de Materiais Inconsolidados}

A definição das principais unidades de materiais inconsolidados (maciços terrosos) presentes na área de estudo baseou-se na classificação de perfis de alteração proposta por Vaz (1996), que utiliza critérios genéticos (solos residuais e transportados) e parâmetros geológico-geotécnicos, da mecânica dos solos e das rochas (textura, índices físicos, escavabilidade, grau de alteração, fraturamento, resistência, etc.)

O mapa de materiais inconsolidados foi elaborado com base no mapa de unidades geológicas, mapa de declividades, análise e interpretação das imagens digitais, levantamentos de campo, dados de sondagens à percussão e de poços (rasos e profundos) e ensaios de laboratório (granulometria).

Foram identificados cinco grandes unidades de materiais inconsolidados: depósitos aluvionares (DA), solo residual de arenito, da Formação Itaqueri $(\mathrm{RI})$, solo residual da Formação Adamantina (RA) e solo residual dos basaltos e intrusivas básicas associados da Formação Serra Geral, subdividido nos tipos 1 e 2 (R1SG e R2SG) em função da declividade (< ou $\geq 30 \%$ ), que reflete diretamente no grau de evolução pedológico e nas características gerais do perfil de alteração (estrutura, textura, resistência, etc.).

\subsubsection{Dados Geológico-Geotécnicos}

Foram levantados dados geológico-geotécnicos, junto aos órgãos municipais e estaduais, empresas particulares, e nas visitas de campo. 
Os dados abrangem: boletins de sondagens SPT, perfis geológicos de poços de captação de água subterrânea e de poços de observação, e ainda, locais de afloramentos rochosos na área de estudo.

As sondagens à percussão com ensaio SPT (Standart Penetration Test) com profundidades variando entre 1 e 30 metros, forneceram dados sobre: consistência ou compacidade dos solos (valores SPT), profundidade do nível d'água e topo rochoso (impenetrável ao SPT).

Os locais com sondagens à percussão foram locados na malha viária utilizando-se o programa CADMap, e posteriormente através da ferramenta Surface Tools (Arcview 3.2a) extraiu-se do MDT as cotas das bocas dos furos. Através dos boletins de sondagens identificaram-se as profundidades do NA e do topo rochoso (basalto), quando atingido pela perfuração.

Ainda para a formação de um Banco de Dados (BD) elaborou-se uma tabela, onde cada sondagem foi descrita metro a metro, com o valor de SPT, nível d'água e topo rochoso quando atingido, totalizando 135 pontos de sondagens SPT.

Os perfis geológicos de poços tubulares profundos perfurados para extração de água subterrânea para abastecimento público e particular foram locados na base cartográfica. Os boletins dos perfis dos poços, muitas vezes, não dispunham da localização geográfica do furo, assim optou-se por ir a cada local, onde foram coletadas as coordenadas no sistema de projeção UTM-SAD69, adotado nos produtos cartográficos na pesquisa. Utilizou-se um Global Positioning System (GPS) portátil (com precisão média de 10 metros para o registro das coordenadas). As cotas das bocas dos poços foram obtidas da mesma maneira descrita para as sondagens SPT.

Também foram catalogados perfis geológicos de poços de observação utilizados em sua grande maioria em poços de combustíveis para monitoramento da Companhia de Tecnologia e Saneamento Ambiental (CETESB). O posicionamento dos pontos na base cartográfica foi realizado da mesma maneira descrita para os poços tubulares profundos.

Durante as visitas a campo foram catalogados os locais que apresentavam afloramentos rochosos, sendo demarcadas a posição geográfica com auxílio de GPS e a profundidade do topo rochoso com a trena, em seguida estes pontos foram locados no MDT e com o auxílio da ferramenta surface tools foram 
extraídas as cotas da superfície. Todos estes pontos foram inseridos em uma tabela no formato excel e inseridos no arcview, sendo posteriormente transformados em arquivo shape representado por pontos.

\subsubsection{Mapa de Zoneamento}

O Mapa de Zoneamento do município de Jaú, contido na Lei Complementar 443 de 2012, foi disponibilizado pela prefeitura em formato digital $d w g$ (polígonos), sendo exportado para formato shape.

No Arcview foram anexadas as informações na tabela de atributos do arquivo, e também utilizando a ferramenta geoprocessing wizard na função join pode-se vincular as zonas para cada lote da base cartográfica.

\subsubsection{8 Áreas de Risco à erosão e à inundação}

Os principais impactos na área urbana relacionados ao meio físico são as erosões e as inundações.

Os pontos de inundações foram obtidos a partir dos dados coletados nos meios de comunicação do município (jornal Comércio de Jahu), pela defesa civil (ROLLEMBERG et. al. 2011).

As erosões foram digitalizadas na base cartográfica com auxilio do fotomosaico e com visitas realizadas em locais que já apresentavam problemas, nestas visitas foram realizadas medidas dos comprimentos das ravinas e voçorocas, e no caso de erosões em sulco e laminar foram levantadas a área afetada. 


\subsubsection{9 Áreas de Proteção Ambiental}

As Áreas de Preservação Permanente (APP) associadas às áreas com declividade superior a $45^{\circ}(100 \%)$ não ocorrem na área de estudo.

As principais áreas de Proteção Ambiental regulamentadas pela legislação federal e municipal foram cartografadas na área de estudo, como a Reserva de Patrimônio Particular Natural (RPPN) Amadeu Botelho definida pelo Decreto No. 1.922 (BRASIL, 1996)

$\mathrm{E}$ as zonas de proteção ambiental estabelecidas pela Lei Complementar 442 de 2012 que trata do Zoneamento na área urbana do município de Jaú. Estas são as Zonas Especiais de Parques Urbanos (ZEPUR) e as Zonas Especiais do Rio Jaú (ZERJ).

As áreas de ZEPUR e ZERJ foram fornecidas pela Prefeitura Municipal em arquivo digital $d w g$.

\subsubsection{Infraestrutura Urbana e Dados Censitários}

Os mapas das redes de abastecimento de água e de coleta de esgoto foram fornecidos pelo Serviço de Água e Esgoto de Jaú (SAEMJA), e contem as informações de derivações e diâmetros dos trechos das redes

Os dados censitários foram cedidos pelo escritório do IBGE em Jaú, e disponibilizados para utilização nesta pesquisa em documentos impressos.

O mapa dos setores censitários foi digitalizado no programa cadmap e exportado em formato shape. No arcview foi estruturada uma tabela relacionando as informações de cada setor.

Estas informações tratam de dados sociais como: quantidade de pessoas recenseadas, quantidade total de residências e quantidade de residências ocupadas. Todos os dados estão relacionados por setor censitário do ano de 2010 . 


\subsubsection{Patrimônio Histórico}

Os imóveis tombados no município de Jaú estão descritos em uma lista na Lei Complementar 277 de 2006, o Plano Diretor Municipal. A partir desta lista foram visitados todos os imóveis e seus respectivos cadastros Imobiliários anotados, depois estes imóveis foram marcados no tema lotes com os respectivos graus de tombamento.

\subsubsection{Definição das análises, ferramentas e produtos}

As funções do sistema foram definidas conforme a necessidade dos usuários da prefeitura, para isto foi necessário o acompanhamento das diversas atividades realizadas na Secretaria de Obras de Jaú, ligadas a gestão urbana.

A partir da avaliação destas atividades foram definidas as ferramentas que comporiam o sistema customizado, suas análises e produtos.

\subsubsection{Definição das formas de apresentação dos resultados}

A apresentação dos resultados do programa foi definida a partir das necessidades dos gestores municipais e das ferramentas disponibilizadas no sistema.

Avaliaram-se as principais demandas de trabalho da gestão pública e definiram-se as melhores opções de apresentação dos resultados em tela e as saídas impressas, suas escalas e tamanhos de papel. 


\subsection{Aplicação e Validação do Sistema na Prefeitura de Jaú}

Uma versão inicial do sistema começou a ser utilizada na Secretaria de Obras de Jaú, foram feitos ajustes e modificações na customização, buscando melhorar a interface com o usuário.

Nesta fase, os gestores da prefeitura fizeram uso do sistema e puderam contribuir para seu aperfeiçoamento. Um total de cinco versões foram desenvolvidas para se alcançar o sistema final.

\subsection{Análise dos Resultados}

O funcionamento do sistema e os resultados de sua aplicação na Secretaria de Obras de Jaú foram analisados com base nas hipóteses de trabalho e objetivos propostos.

\subsection{Conclusões e Redação da Tese}

Na conclusão do trabalho foi avaliada a sua importância e a sua efetiva utilização dentro da gestão pública municipal.

A redação da tese teve duas etapas principais, na primeira etapa foram relatados os objetivos do trabalho, os referenciais teóricos (Referências Bibliográficas) a caracterização da área de estudo e da metodologia, na segunda foram apresentados os resultados, as análises dos resultados e a conclusão. 


\subsection{Materiais utilizados}

A partir da definição da área estudada, fez-se o levantamento dos dados já existentes em trabalhos anteriores, em órgãos públicos e empresas do setor geotécnico.

Para elaboração da base cartográfica e dos mapas temáticos fez-se uso de fotografias aéreas, mapas, programas computacionais e outras ferramentas. A seguir tais materiais são descritos.

Nas Tabelas 5.4 e 5.5 estão descritos os materiais (mapas e fotografias aéreas) utilizados na elaboração da base cartográfica, e na identificação preliminar das unidades geológico-geotécnicas.

Tabela 5.4: Mapas utilizados na pesquisa.

\begin{tabular}{|c|c|c|c|c|c|}
\hline Mapa & Identificação das Folhas & Escala & Executor & ANO & $\begin{array}{c}\text { Projeção } \\
\text { Cartográfica }\end{array}$ \\
\hline $\begin{array}{l}\text { Plano Cartográfico } \\
\text { do Estado de São } \\
\text { Paulo }\end{array}$ & $\begin{array}{l}\text { JAÚ I-SF-22-Z-B-II-4-NE-A } \\
\text { JAUU II-SF-22-Z-B-II-4-NE-B } \\
\text { JAUU III-SF-22-Z-B-II-4-NE-C } \\
\text { JAUU IV-SF-22-Z-B-II-4-NE-D } \\
\text { VILA RIBEIRO-SF-22-Z-B-II-4-NE-E } \\
\text { NAVARROS-SF-22-Z-B-II-4-NE-F } \\
\text { IBIRAPITANGA-SF-22-Z-B-II-2-SE-E } \\
\text { SÃO LOURENÇO-SF-22-Z-B-II-2-SE-F } \\
\text { POTUNDUVA-SF-22-Z-B-II-4-NO-F }\end{array}$ & 1:10.000 & $I_{G C}^{*}$ & 1980 & $\begin{array}{l}\text { UTM - Córrego } \\
\text { Alegre }\end{array}$ \\
\hline $\begin{array}{c}\text { Mapa Geológico } \\
\text { do Estado de São } \\
\text { Paulo }\end{array}$ & Folha de Bauru & $1: 250.000$ & $\mathrm{DAEE}^{* *}$ & 1984 & $\begin{array}{c}\text { UTM - Córrego } \\
\text { Alegre }\end{array}$ \\
\hline $\begin{array}{c}\text { Mapa Geológico } \\
\text { do Estado de São } \\
\text { Paulo }\end{array}$ & Folha B & $1: 500.000$ & IPT & 1981 & $\begin{array}{c}\text { UTM - Córrego } \\
\text { Alegre }\end{array}$ \\
\hline $\begin{array}{l}\text { Levantamento } \\
\text { Pedológico Semi- } \\
\text { Detalhado do } \\
\text { Estado de São } \\
\text { Paulo } \\
\end{array}$ & $\begin{array}{l}\text { Quadricula Jaú } \\
\text { SF.22-Z-B-II }\end{array}$ & $1: 100.000$ & $I A C^{* * *}$ & 1982 & $\begin{array}{l}\text { UTM - Córrego } \\
\text { Alegre }\end{array}$ \\
\hline
\end{tabular}


Tabela 5.5: Relação e características das fotografias aéreas utilizadas na pesquisa.

\begin{tabular}{lccccc}
\hline Ano & Tipo & Projeção Cartográfica & Escala & Fonte & Cedida por \\
\hline 2000 & Mosaico Digital & UTM - SAD69 & $1: 12.500$ & Base SA & SAEMJA $^{*}$ \\
2005 & Mosaico Digital & UTM - SAD69 & $1: 8.000$ & Engemap & PM* de Jahu $^{* *}$ \\
2011 & Mosaico Digital & UTM - SAD69 & - & Google Maps & Fatec Jahu \\
\hline
\end{tabular}

Serviço de Água e esgoto do Município de Jaú

Prefeitura Municipal

O software utilizado a produção do sistema de informações para o município de Jau foi o ArcView GIS 3.2a. Este programa foi escolhido pelos seguintes motivos:

a) interface simples para usuários não especialistas;

b) fácil manipulação de dados em outros formatos como: CAD ou Excel;

c) domínio do uso do software pela autora;

d) não é mais comercializado, assim não há necessidade de licença;

e) é suportado por computadores com baixa memória (muito comum em prefeituras);

f) possui linguagem de programação própria, podendo ser personalizado.

Outros softwares eventualmente foram utilizados como: CADMAP, SPRING e ARCGIS 9.1. A Tabela 5.6 descreve as etapas em que cada software foi utilizado.

Tabela 5.6: Relação de programas utilizados na pesquisa

\begin{tabular}{cl}
\hline Software & \multicolumn{1}{c}{ Uso na pesquisa } \\
\hline SPRING & Georreferenciamento dos mapas base \\
Versão 6.1 & Digitalização das folhas altimétricas e localização de pontos na \\
Auto CADMAP & malha urbana. \\
2004 & Confecção dos mapas, análise visual das áreas e implantação \\
ArcView & do Sistema Customizado. \\
GIS versão 3.2a & Elaboração de tabelas \\
Excel 2003 &
\end{tabular}




\section{RESULTADOS}

O sistema de apoio a gestão urbana proposto neste trabalho contém uma base de dados integrada, sendo dados de natureza: física (geotécnica), social e ambiental.

Neste item, serão descritos os mapas e os dados produzidos para alimentar o sistema. Também será apresentada a interface do sistema, com suas funções e ainda alguns exemplos de utilização que foram realizados na validação da pesquisa.

\subsection{Mapas e dados produzidos}

Todos os dados e mapas produzidos para alimentar o sistema foram construídos conforme as metodologias descritas no item 5 , nos itens que seguem tais produtos serão apresentados. 


\subsubsection{Base Cartográfica, Hipsometria e Declividade}

A base cartográfica desenvolvida para este trabalho é composta por 8 temas vetoriais, sendo eles: curvas de nível $(5 \mathrm{~m})$, drenagem, microbacias hidrográficas, perímetro urbano, sistema viário, logradouros, bairros e lotes. E ainda mais duas imagens raster uma de 2005 e outra de 2010. A Figura 6.1 apresenta um fragmento da base cartográfica sobreposta ao fotomosaico de 2010.

O mapa da Figura 6.2 traz a hipsometria para a área (Produzida a partir do MDT), onde podem ser observadas as amplitudes topográficas e os desníveis altimétricos. Na área de estudo a variação máxima de altitude é de 230 metros.

A Figura 6.3 ilustra um fragmento do Mapa de Declividade, a faixa de declividade predominante na área é de 0 a $6 \%$, chegando a 56,9 \% da área total (Tabela 6.1).

Tabela 6.1: Distribuição das classes de declividade na área de estudo

\begin{tabular}{ccc}
\hline $\begin{array}{c}\text { Classes de } \\
\text { Declividade } \\
(\%)\end{array}$ & Área $\left.\mathbf{( k m}^{\mathbf{2}}\right)$ & $\begin{array}{c}\text { \% da área } \\
\text { total }\end{array}$ \\
\hline $0-6$ & 152,1 & 57,0 \\
$6-15$ & 93,6 & 34,8 \\
$15-30$ & 19,5 & 7,3 \\
$>30$ & 2,5 & 0,9 \\
Total & & 267,7 \\
\hline
\end{tabular}




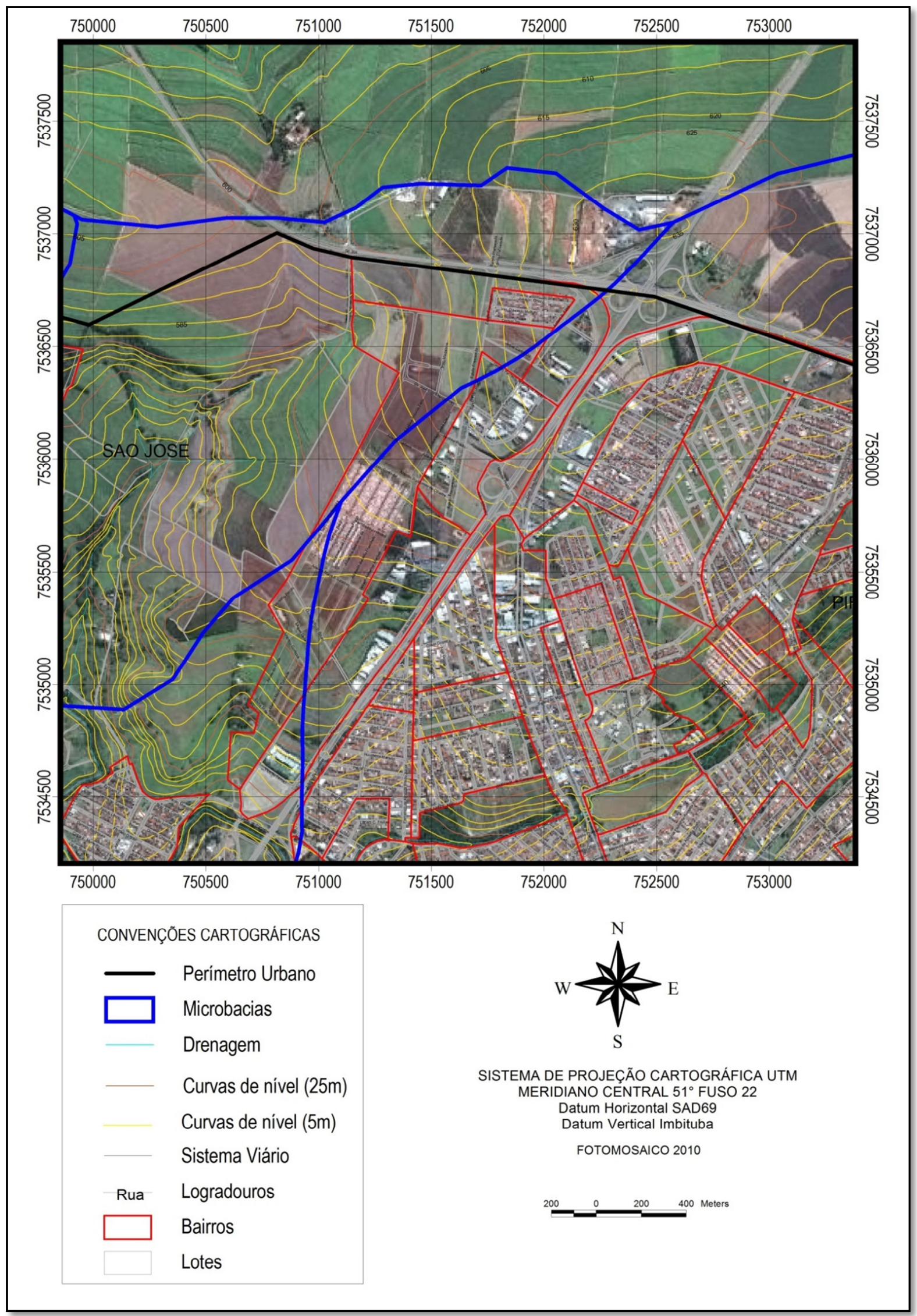

Figura 6.1: Base Cartográfica - escala 1:25.000 


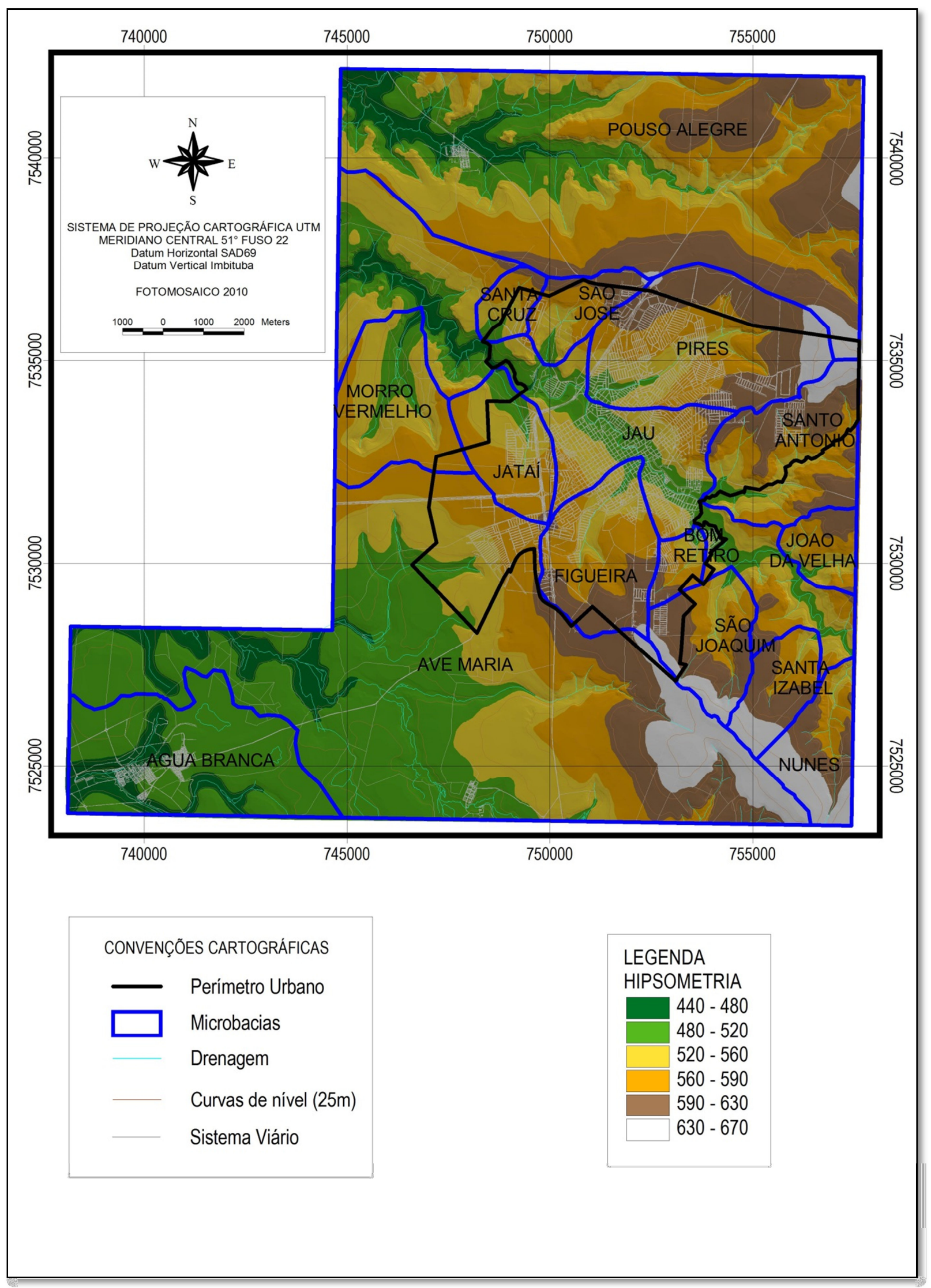

Figura 6.2: Mapa de Hipsometria - escala 1:140.000 


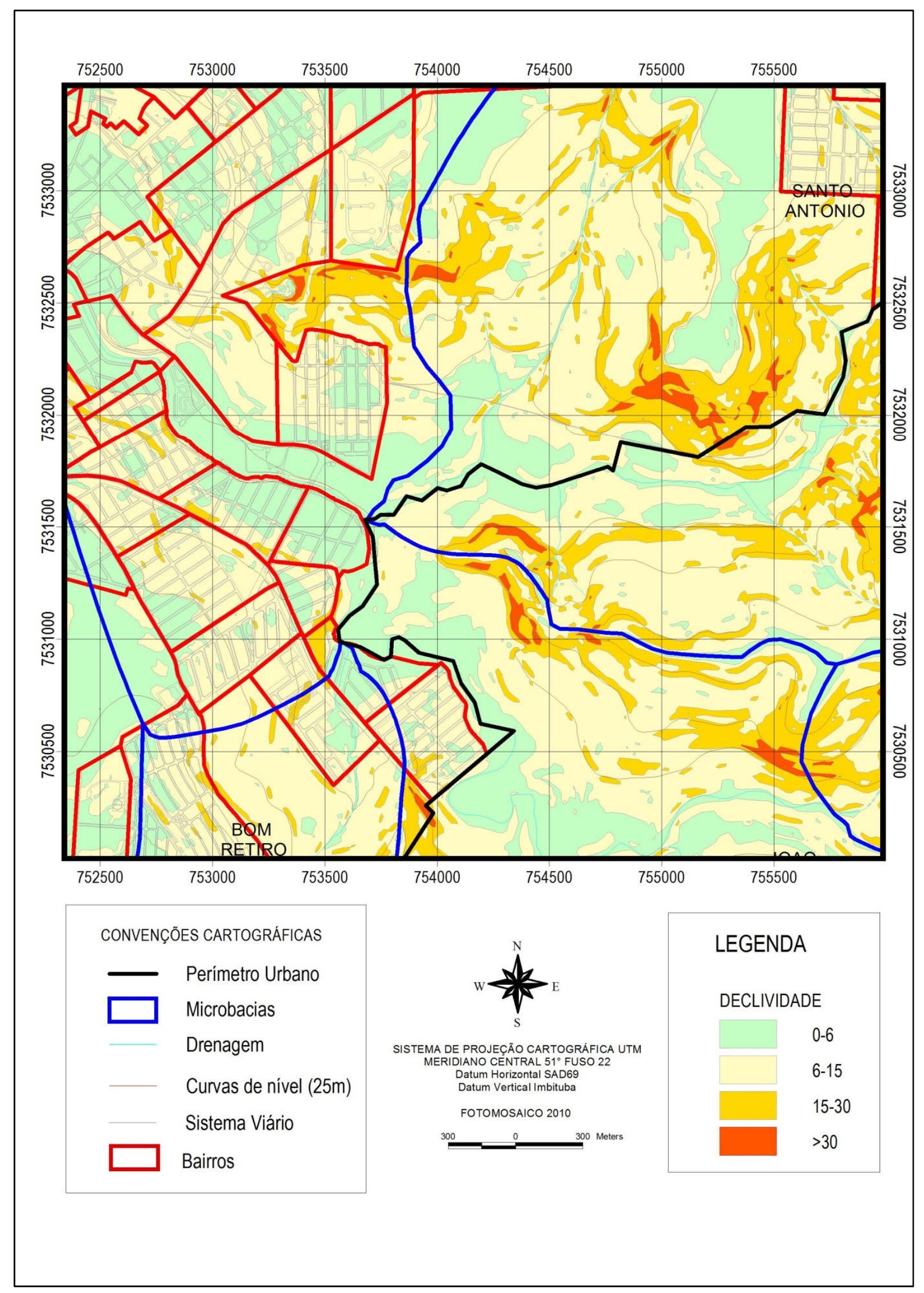

Figura 6.3: Fragmento do Mapa de Declividade - escala 1:25.000 


\subsubsection{Mapa de Unidades Geológicas}

As principais formações geológicas que ocorrem na área de estudo são a Serra Geral e a Itaqueri, segundo os mapas geológicos do DAEE (1982) e do IPT (1981), e de acordo com as pesquisas de campo, a Unidade Adamantina também é encontrada na área sudoeste do município, no distrito de Potunduva.

A Formação Serra Geral (Grupo São Bento) de idade cretáceajurássica é caracterizada pelos derrames de lavas eruptivas superpostas que abrangem áreas enormes com camadas espessas, tendo coloração de cinza a negra e uma textura afanítica (minerais não visíveis a olho nu). É composta essencialmente por basaltos que apresentam espessura individual bastante variável, desde poucos metros a mais de $50 \mathrm{~m}$ e extensão individual que pode ultrapassar a dez quilômetros. Neles, intercalam-se arenitos com as mesmas características dos arenitos da Formação Botucatu, a maioria com estruturas típicas de dunas e outros indicando deposição subaquosa. Também estão presentes rochas intrusivas básicas de idade correlata aos basaltos, compostas por diques e sills de diabásio. (PONÇANO et al. 1981).

A Formação Itaqueri de idade cretácea-terciária constitui-se de um pacote de até 120 metros de espessura, de camadas alternadas de arenitos com cimento argiloso, folhetos e conglomerados, estes situados tanto na base quanto no interior do pacote. Os arenitos são de granulação variada, podem ser argilosos e apresentar intensa silicificação. Os clastos dos conglomerados são de composição variada, provenientes de fora da bacia de deposição. Estes sedimentos foram acumulados em ambiente de elevada energia, sujeitos à mudanças bruscas de velocidade das águas, possivelmente em depósitos de leques aluviais em clima de acentuada aridez (IPT, 1993).

Recobrindo estas duas unidades geológicas, ocorrem as coberturas cenozóicas compostas basicamente de depósitos aluvionares associados às maiores drenagens presentes na área de estudo.

Os ensaios de laboratório auxiliaram na identificação da Formação Adamantina na região do distrito de Potunduva, região com baixas altitudes e muito próxima a calha do Rio Tietê. 
A Formação Adamantina foi formalmente proposta por Soares et al. (1980) como um conjunto de fácies compostas por bancos de arenito portando estratificação cruzada, intercalados a bancos de lamitos, siltitos e arenitos lamíticos. O ambiente de deposição desta unidade é considerado, por seus pesquisadores, como tendo sido flúvio-lacustre (Fernandes, 1998).

Em termos paleoambientais, a Formação Adamantina compreende depósitos arenosos acanalados, com padrão granulométrico em fining upward e eventuais terminações em sedimentos pelíticos, sugestivos de sedimentação fluvial em canais meandrantes, com eficiência em produtos silto-argilosos. A sucessão, como um todo, mostra padrão indicativo de sedimentação em sistemas fluviais progradantes, fomentadores do processo de assoreamento da bacia. (Paula e Silva et al, 2003).

A Tabela 6.2 apresenta as áreas que cada unidade geológica ocupa na área de estudo. A Formação Serra Geral ocupa a maior parte da área chegando a $74,4 \%$ da área total, a Figura 6.4 ilustra o Mapa de Unidades Geológicas da área de estudo.

Tabela 6.2: Distribuição das unidades geológicas na área de estudo

\begin{tabular}{lcc}
\hline UNIDADE GEOLÓGICA & ÁREA $\left(\mathrm{Km}^{2}\right)$ & $\begin{array}{c}\text { \% DA ÁREA } \\
\text { TOTAL }\end{array}$ \\
\hline DEPÓSITOS ALUVIONARES & 10,3 & 3,8 \\
FORMAÇÃO ITAQUERI & 40,9 & 15,3 \\
FORMAÇÃO ADAMANTINA & 25,7 & 9,6 \\
FORMAÇÃO SERRA GERAL & 190,8 & 71,3 \\
\hline ÁREA TOTAL & \multicolumn{2}{c}{267,7} \\
\hline
\end{tabular}




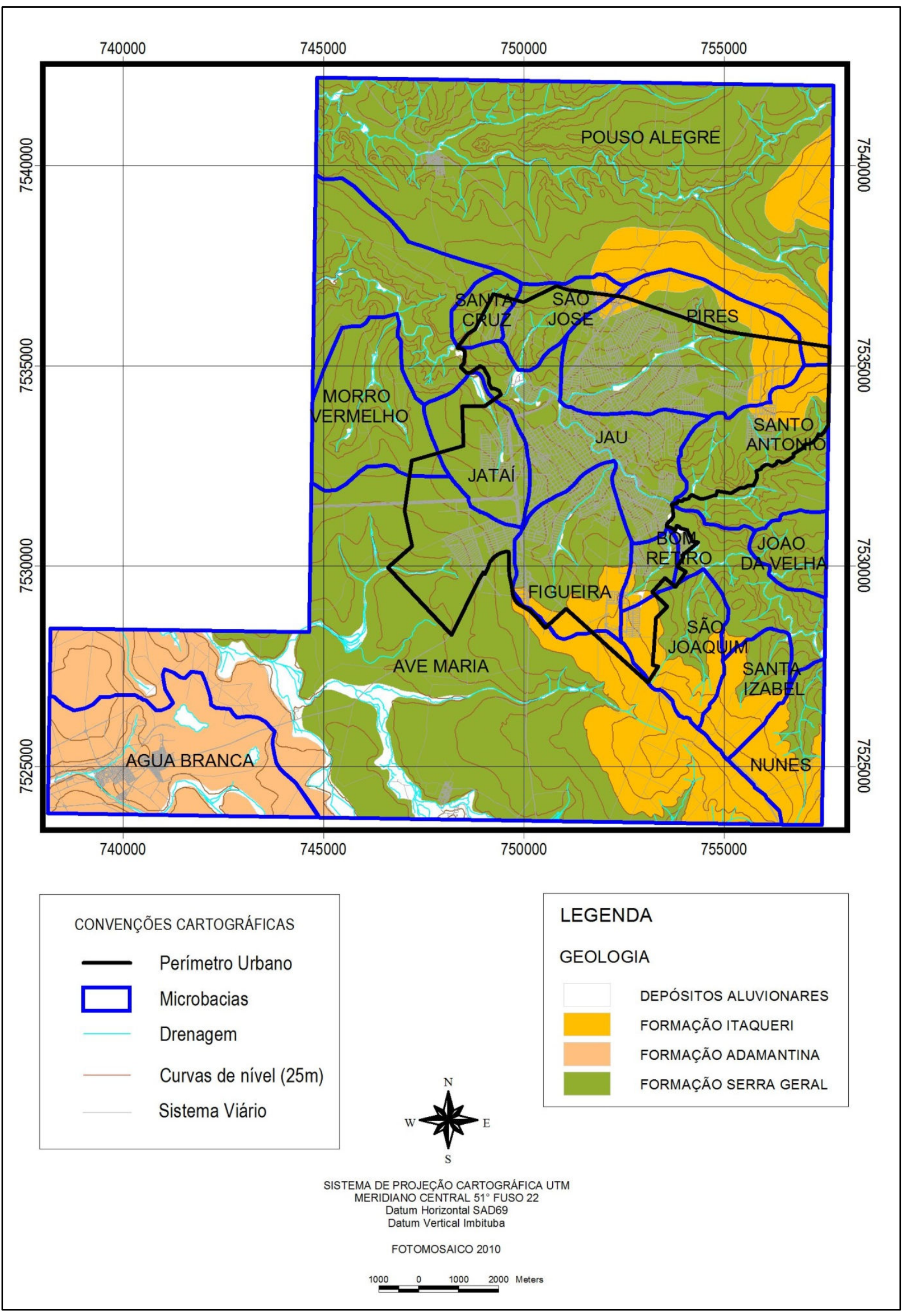

Figura 6.4: Mapa de Unidades Geológicas - Escala 1:140.000 


\subsubsection{Mapa de Materiais Inconsolidados}

$\mathrm{Na}$ área de estudo foram mapeados cinco unidades de materiais inconsolidados (solos/maciços terrosos), sendo uma de origem transportada (depósito aluvionar) e as demais de origem residual, formados a partir da alteração e a pedogênese de material in situ. Além dos depósitos aluvionares de origem transportada, também ocorrem depósitos coluvionares não mapeáveis na escala de trabalho da pesquisa.

A unidade de Depósitos Aluvionares ocorre nas planícies das drenagens mais importantes, estando diretamente associados à dinâmica de transporte e erosão dos rios.

Os solos residuais da Formação Itaqueri ocorrem nas porções sudoeste e nordeste da área de estudo. A unidade da Formação Adamantina está presente no setor sudoeste, ocupando terrenos com baixas altitudes e declividades, próximos à calha do Rio Tietê.

Os solos da Formação Serra Geral foram subdivididos em dois tipos denominados de residuais jovens e maduros, ocorrências em função da declividade. Os solos residuais jovens ocorrem nos trechos de declividade mais acentuada. A Tabela 6.3 apresenta a distribuição em área de cada uma destas unidades.

Tabela 6.3: Distribuição dos materiais inconsolidados na área de estudo

\begin{tabular}{lcc}
\hline SOLOS & $\begin{array}{c}\text { ÁREA } \\
\left(\mathbf{K m}^{2} \mathbf{)}\right.\end{array}$ & $\begin{array}{c}\text { \% DA ÁREA } \\
\text { TOTAL }\end{array}$ \\
\hline DEPÓSITOS ALUVIONARES & 10,3 & 3,8 \\
RESIDUAL DA FORMAÇÃO ITAQUERI & 40,9 & 15,3 \\
RESIDUAL DA FORMAÇÃO ADAMANTINA & 26,3 & 9,8 \\
RESIDUAL DA FORMAÇÃO SERRA GERAL JOVEM & 9,4 & 3,5 \\
RESIDUAL DA FORMAÇÃO SERRA GERAL MADURO & 180,8 & 67,6 \\
\hline TOTAL & \multicolumn{2}{c}{267,7} \\
\hline
\end{tabular}




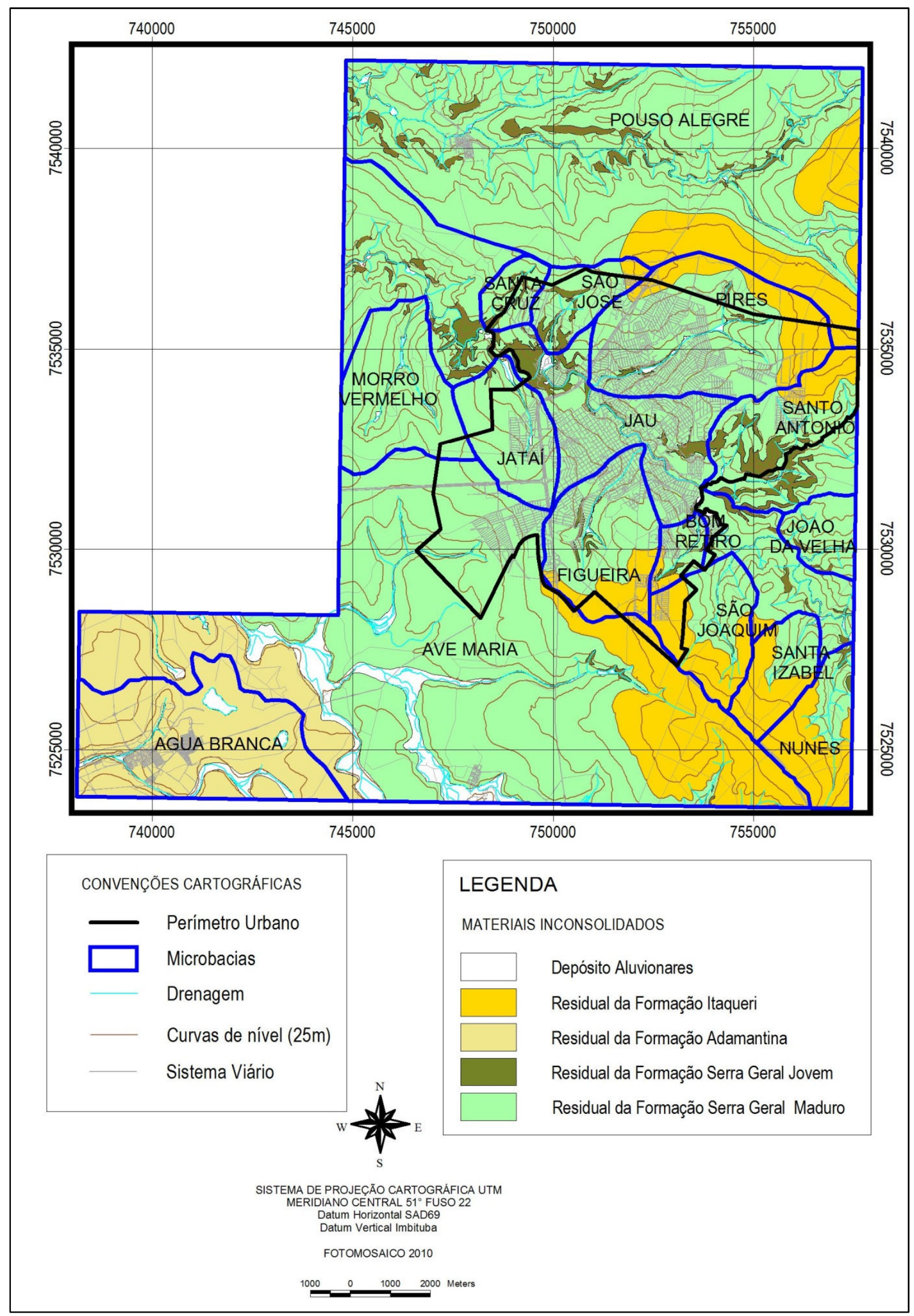

Figura 6.5: Mapa de Materiais Inconsolidados - Escala 1:140.000 
Os dados de caracterização textural dos solos foram obtidos através dos ensaios de granulometria realizados para 12 amostras. Na Tabela 6.4 são descritos os tipos de solos diagnosticados para a área.

A Tabela 6.5 apresenta a síntese dos resultados da análise granulométrica conjunta para as 12 amostras ensaiadas.

Tabela 6.4 Síntese das características geológico-geotécnicas dos materiais inconsolidados mapeados.

\begin{tabular}{|c|c|c|}
\hline $\begin{array}{c}\text { Material } \\
\text { Inconsolidado }\end{array}$ & Sigla & Características geológico-geotécnicas \\
\hline $\begin{array}{l}\text { Depósitos } \\
\text { aluvionares }\end{array}$ & DA & $\begin{array}{l}\text { Solo transportado, cuja distribuição é governada por } \\
\text { cursos d'água e pelo relevo (baixas declividades), } \\
\text { pode possuir matéria orgânica, reduzindo sua } \\
\text { capacidade de suporte, sendo um solo com alta } \\
\text { restrição à ocupação. }\end{array}$ \\
\hline $\begin{array}{l}\text { Solo residual da } \\
\text { Formação } \\
\text { Itaqueri }\end{array}$ & $\begin{array}{c}\text { RI } \\
\text { (Figura 6.6) }\end{array}$ & $\begin{array}{l}\text { Textura arenosa, areno-argilosa ou argilo-arenosa; de } \\
\text { cor avermelhada originário do arenito, suscetível à } \\
\text { processos erosivos. }\end{array}$ \\
\hline $\begin{array}{l}\text { Solo Residual da } \\
\text { Formação } \\
\text { Adamantina }\end{array}$ & $\begin{array}{c}\text { RA } \\
\text { (Figura 6.7) }\end{array}$ & $\begin{array}{l}\text { Textura arenosa ou argilo-arenosa; de cor } \\
\text { avermelhada originário do arenito, granumetria de } \\
\text { média a fina, suscetível à processos erosivos. }\end{array}$ \\
\hline \multirow[t]{2}{*}{$\begin{array}{l}\text { Solo residual da } \\
\text { Formação Serra } \\
\text { Geral }\end{array}$} & $\begin{array}{c}\text { R1SG } \\
\text { (Figura 6.8) }\end{array}$ & $\begin{array}{l}\text { Horizonte de solo residual maduro pouco espesso, } \\
\text { ocorrência de horizonte de solo residual jovem, e } \\
\text { eventualmente do topo rochoso a profundidades } \\
\text { reduzidas }(<5 \mathrm{~m}) \text {. Presença de estruturas reliquiares } \\
\text { da rocha mãe, cores variegadas, textura argilosa com } \\
\text { fragmentos de rocha. }\end{array}$ \\
\hline & $\begin{array}{c}\text { R2SG } \\
\text { (Figura 6.9) }\end{array}$ & $\begin{array}{l}\text { Horizonte de solo residual maduro espesso }(>5 \mathrm{~m}) \\
\text { estrutura homogênea, poroso, laterizado. Textura } \\
\text { argilosa. }\end{array}$ \\
\hline
\end{tabular}


Tabela 6.5: Dados dos ensaios de granulometria conjunta

\begin{tabular}{ccccccc}
\hline \multicolumn{2}{c}{ ENSAIOS } & \multicolumn{5}{c}{ Analise Granulométrica Conjunta } \\
\cline { 3 - 7 } Amostras & Tipo de & ARGILA & SILTE & \multicolumn{3}{c}{ AREIA (\%) } \\
\cline { 3 - 7 } & Solo & $\mathbf{( \% )}$ & $\mathbf{( \% )}$ & FINA & MÉDIA & GROSSA \\
\hline E1 & RI & 22 & 6 & 31 & 40 & 2 \\
E2 & RI & 33 & 14 & 28 & 24 & 2 \\
E3 & R2SG & 56 & 29 & 10 & 5 & 1 \\
E4 & R2SG & 57 & 28 & 11 & 5 & 0 \\
E5 & R2SG & 59 & 23 & 13 & 5 & 1 \\
E6 & R2SG & 62 & 22 & 12 & 4 & 1 \\
E7 & R1SG & 50 & 28 & 18 & 4 & 0 \\
E8 & RI & 24 & 3 & 30 & 40 & 3 \\
E9 & RI & 29 & 12 & 28 & 31 & 0 \\
E10 & R1SG & 53 & 28 & 14 & 5 & 0 \\
E11 & RI & 25 & 6 & 30 & 39 & 1 \\
E12 & RA & 45 & 18 & 20 & 16 & 1 \\
\hline
\end{tabular}

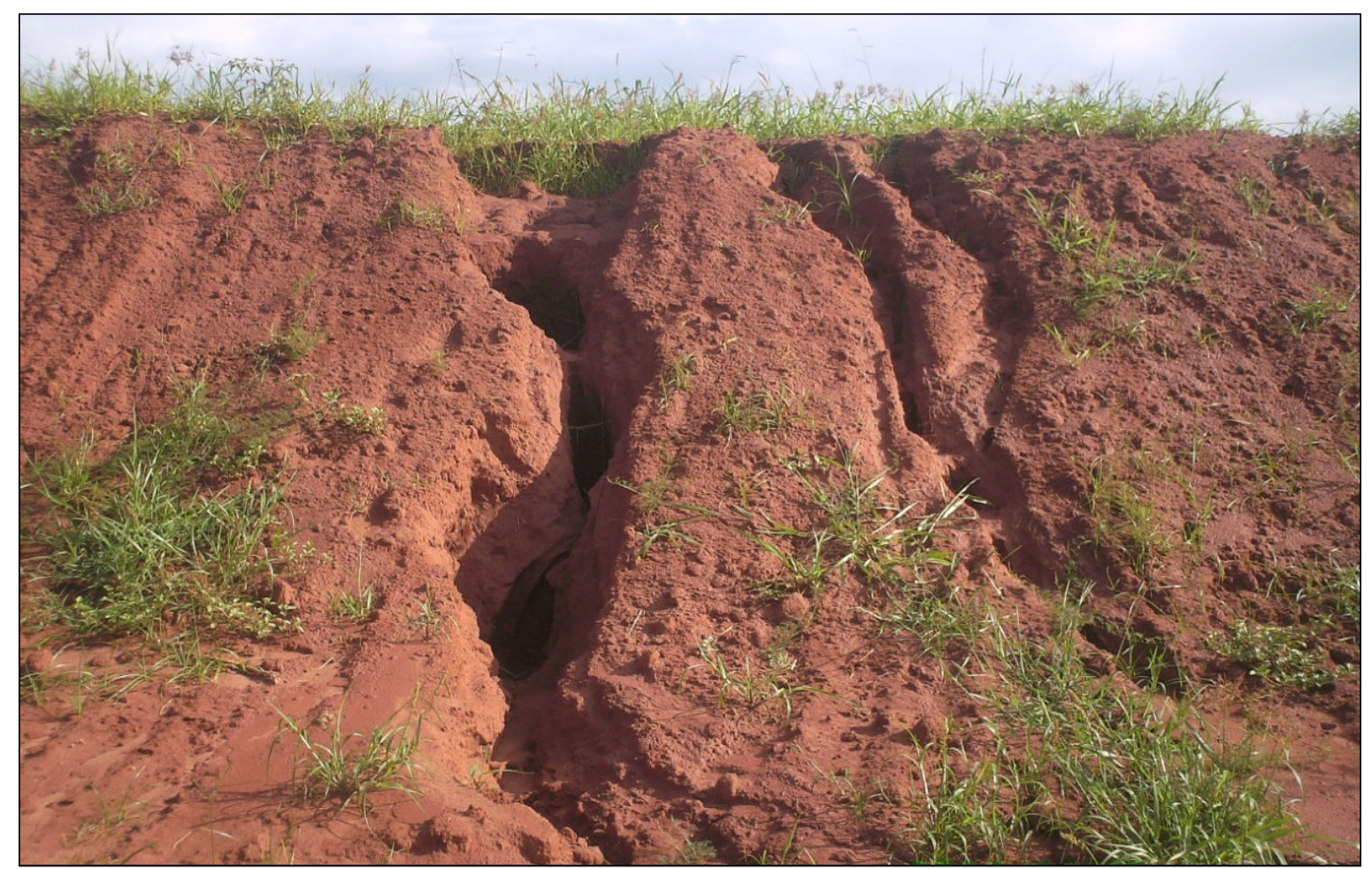

Figura 6.6: Solo Residual da Formação Itaqueri (RI). 


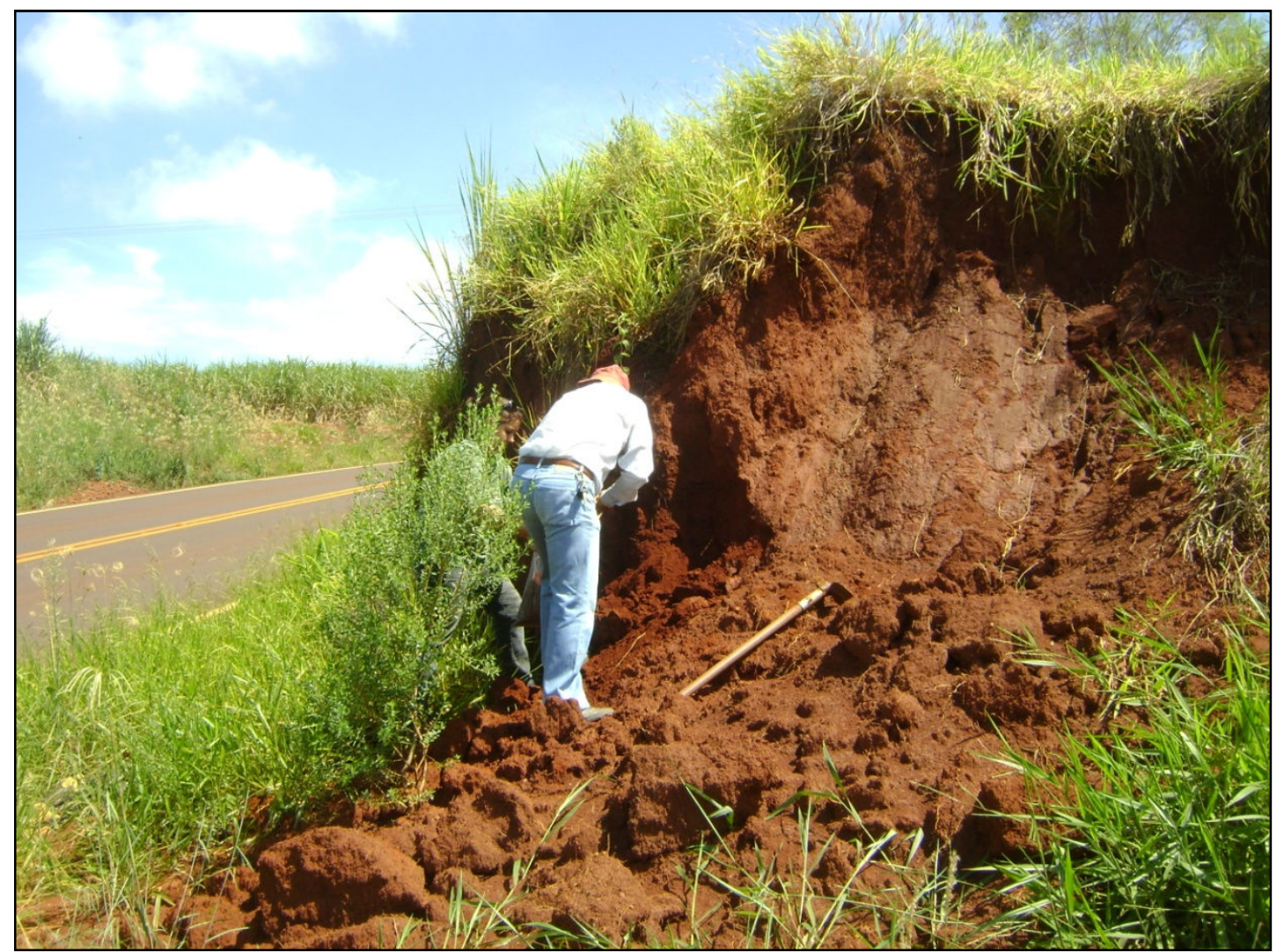

Figura 6.7: Solo Residual da Formação Adamantina (RA)

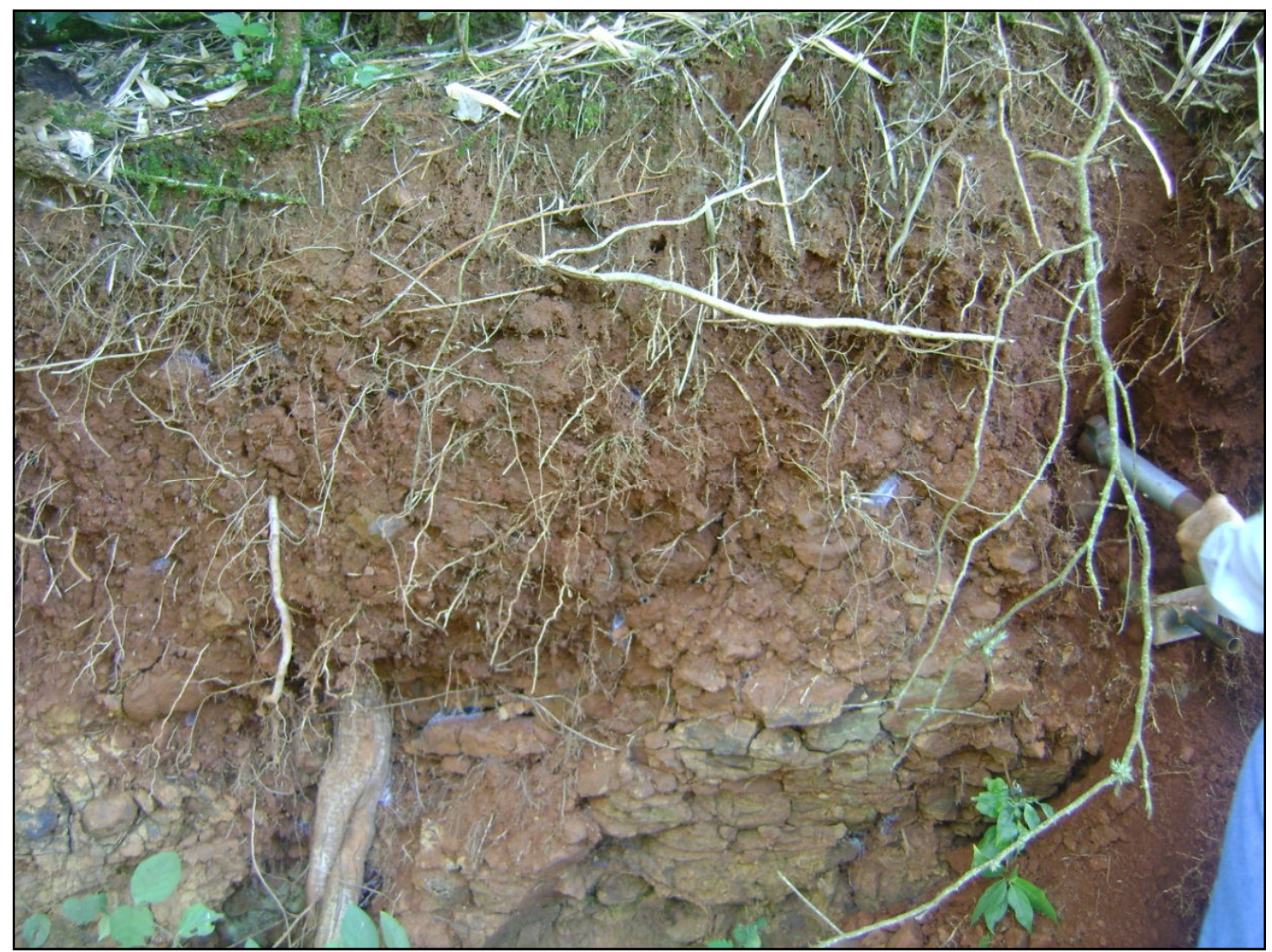

Figura 6.8: Solo Residual da Formação Serra Geral, apresentando estruturas reliquiares do basalto (R1SG). 


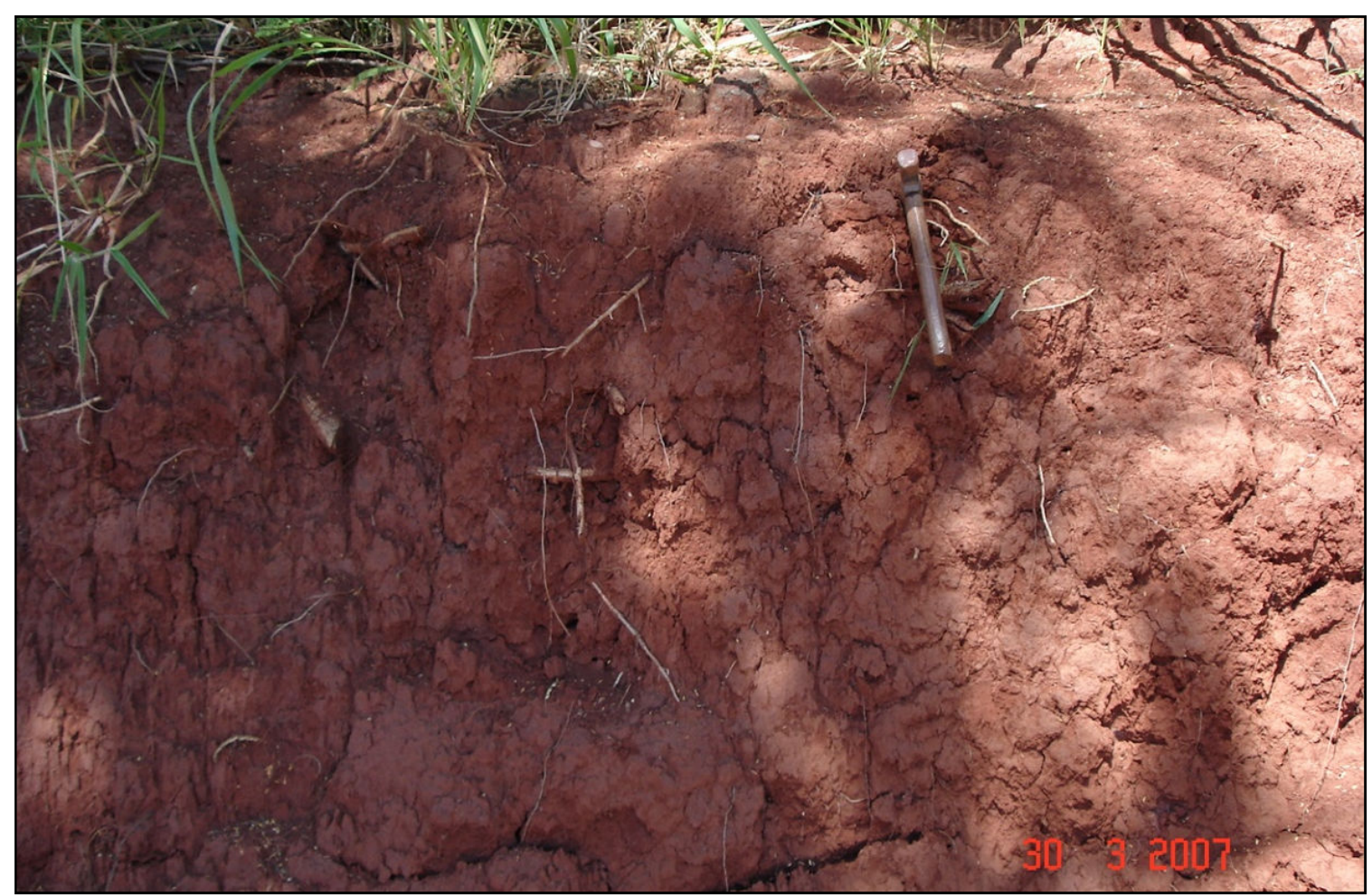

Figura 6.9: Solo Residual da Formação Serra Geral (R2SG).

\subsubsection{Dados geotécnicos}

As sondagens SPT descritas e inseridas na base de dados totalizaram 134 pontos, os furos foram descritos metro a metro. A Tabela 6.6 apresenta um exemplo da descrição do furo de sondagem SPT. A Figura 6.10 apresenta um exemplo das informações disponíveis para consulta da sondagem.

Os perfis de poços tubulares profundos foram inseridos na base de dados. Tabela 6.7 apresenta as características dos 33 poços cadastrados na base de dados, na Figura 6.11 é apresentado um exemplo de cadastro de perfil poço de abastecimento público.

Os poços de observação descritos no sistema totalizam 19 locais. Na Tabela 6.8 são apresentados os poços de observação catalogados e a Figura 6.12 apresenta um exemplo das informações cadastradas. Os afloramentos rochosos (Formação Serra Geral) catalogados foram seis, sendo descritos na Tabela 6.9. A Figura 6.13 apresenta um afloramento rochoso cadastrado no sistema. 
Tabela 6.6: Exemplo da descrição dos dados de Sondagens SPT.

\begin{tabular}{cccccccc}
\hline $\mathbf{N}^{\circ}$ & Prof. & $\mathbf{X}$ & $\mathbf{Y}$ & COTA & Cota Prof. & NSPT & CLASS. \\
\hline S1 & 1,00 & 751339,73 & 7531949,01 & 548,41 & 547,41 & 6,53 & 2 \\
S1 & 2,00 & 751339,73 & 7531949,01 & 548,41 & 546,41 & 4,67 & 2 \\
S1 & 3,00 & 751339,73 & 7531949,01 & 548,41 & 545,41 & 8,00 & 2 \\
S1 & 4,00 & 751339,73 & 7531949,01 & 548,41 & 544,41 & 7,00 & - \\
S1 & 5,00 & 751339,73 & 7531949,01 & 548,41 & 543,41 & 6,53 & - \\
S1 & 6,00 & 751339,73 & 7531949,01 & 548,41 & 542,41 & 8,68 & - \\
S1 & 7,00 & 751339,73 & 7531949,01 & 548,41 & 541,41 & 9,62 & - \\
S1 & 8,00 & 751339,73 & 7531949,01 & 548,41 & 540,41 & 10,56 & - \\
S1 & 9,00 & 751339,73 & 7531949,01 & 548,41 & 539,41 & 12,18 & - \\
S1 & 10,00 & 751339,73 & 7531949,01 & 548,41 & 538,41 & 18,00 & - \\
S1 & 11,00 & 751339,73 & 7531949,01 & 548,41 & 537,41 & 47,00 & - \\
S1 & 12,00 & 751339,73 & 7531949,01 & 548,41 & 536,41 & 55,00 & - \\
Class. 2 = argila arenosa & & & & & \\
\hline \multicolumn{7}{l}{}
\end{tabular}

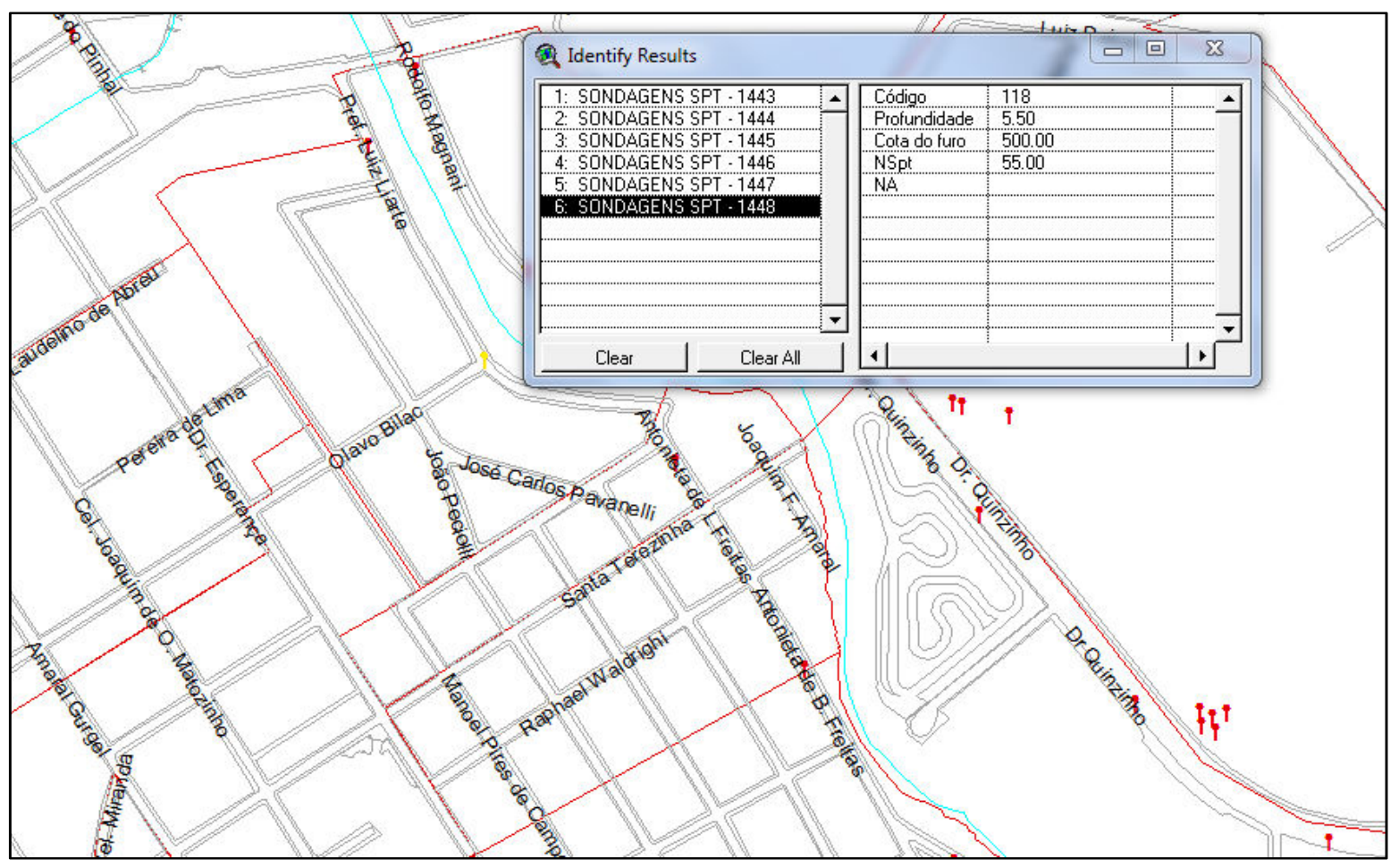

Figura 6.10: Exemplo de sondagem SPT 
Tabela 6.7: Relação das informações de poços tubulares profundos

\begin{tabular}{|c|c|c|c|c|c|c|c|}
\hline NO & $x$ & $\mathbf{Y}$ & Altitude & Prof. & NA & BASALTO & ARENITO \\
\hline 1 & 749078 & 7531745 & 573 & 78 & 17 & 28 & 0 \\
\hline 2 & 752233 & 7533507 & 532 & 101 & 18 & 10 & 0 \\
\hline 3 & 749161 & 7533548 & 514 & 180 & 54 & 11 & 0 \\
\hline 4 & 752128 & 7536134 & 613 & 100 & 27 & 31 & 0 \\
\hline 5 & 752702 & 7533414 & 542 & 90 & 20 & 10 & 0 \\
\hline 6 & 751027 & 7532711 & 531 & 94 & 20 & 19 & 0 \\
\hline 7 & 753777 & 7537572 & 622 & 36 & 16 & 12 & 0 \\
\hline 8 & 751968 & 7532730 & 496 & 80 & 12 & 6 & 0 \\
\hline 9 & 750098 & 7531797 & 586 & 25 & 21 & 0 & 0 \\
\hline 10 & 752242 & 7534061 & 534 & 150 & 33 & 18 & 0 \\
\hline 11 & 751213 & 7531051 & 539 & 276 & 25 & 11 & 267 \\
\hline 12 & 750209 & 7533457 & 527 & 590 & 140 & 4 & 341 \\
\hline 13 & 752355 & 7532691 & 498 & 150 & 4 & 4 & 0 \\
\hline 14 & 750974 & 7534076 & 486 & 150 & 4 & 5 & 0 \\
\hline 15 & 752672 & 7532265 & 497 & 150 & 8 & 10 & 0 \\
\hline 16 & 749443 & 7530893 & 588 & 608 & 179 & 80 & 404 \\
\hline 17 & 756005 & 7532985 & 561 & 92 & 13 & 11 & 0 \\
\hline 18 & 752856 & 7534708 & 520 & 552 & 45 & 9 & 302 \\
\hline 19 & 751242 & 7531417 & 520 & 530 & 68 & 30 & 328 \\
\hline 20 & 750094 & 7534105 & 483 & 149 & 5 & 8 & 0 \\
\hline 21 & 753100 & 7535050 & 524 & 180 & 77 & 66 & 0 \\
\hline 22 & 747017 & 7531648 & 557 & 70 & 22 & 20 & 0 \\
\hline 23 & 750900 & 7532100 & 554 & 110 & 15 & 29 & 0 \\
\hline 24 & 734600 & 7530370 & & 156 & 6 & & 0 \\
\hline 25 & 749100 & 7533950 & 493 & 260 & 140 & 9 & 230 \\
\hline 26 & 745351 & 7531635 & 568 & 313 & 131 & 13 & 312 \\
\hline 27 & 759600 & 7535060 & & 120 & 21 & 23 & 0 \\
\hline 28 & 748800 & 7524000 & 501 & 138 & 10 & 4 & 0 \\
\hline 29 & 749813 & 7532358 & 570 & 190 & 21 & 7 & 0 \\
\hline 30 & 747550 & 7539900 & 480 & 119 & 0 & 18 & 0 \\
\hline 31 & 747930 & 7524100 & 500 & 338 & 0 & 9 & 318 \\
\hline 32 & 748170 & 7524650 & 523 & 100 & 0 & 14 & 0 \\
\hline 33 & 745000 & 7544850 & 460 & 81 & 1 & & 14 \\
\hline
\end{tabular}




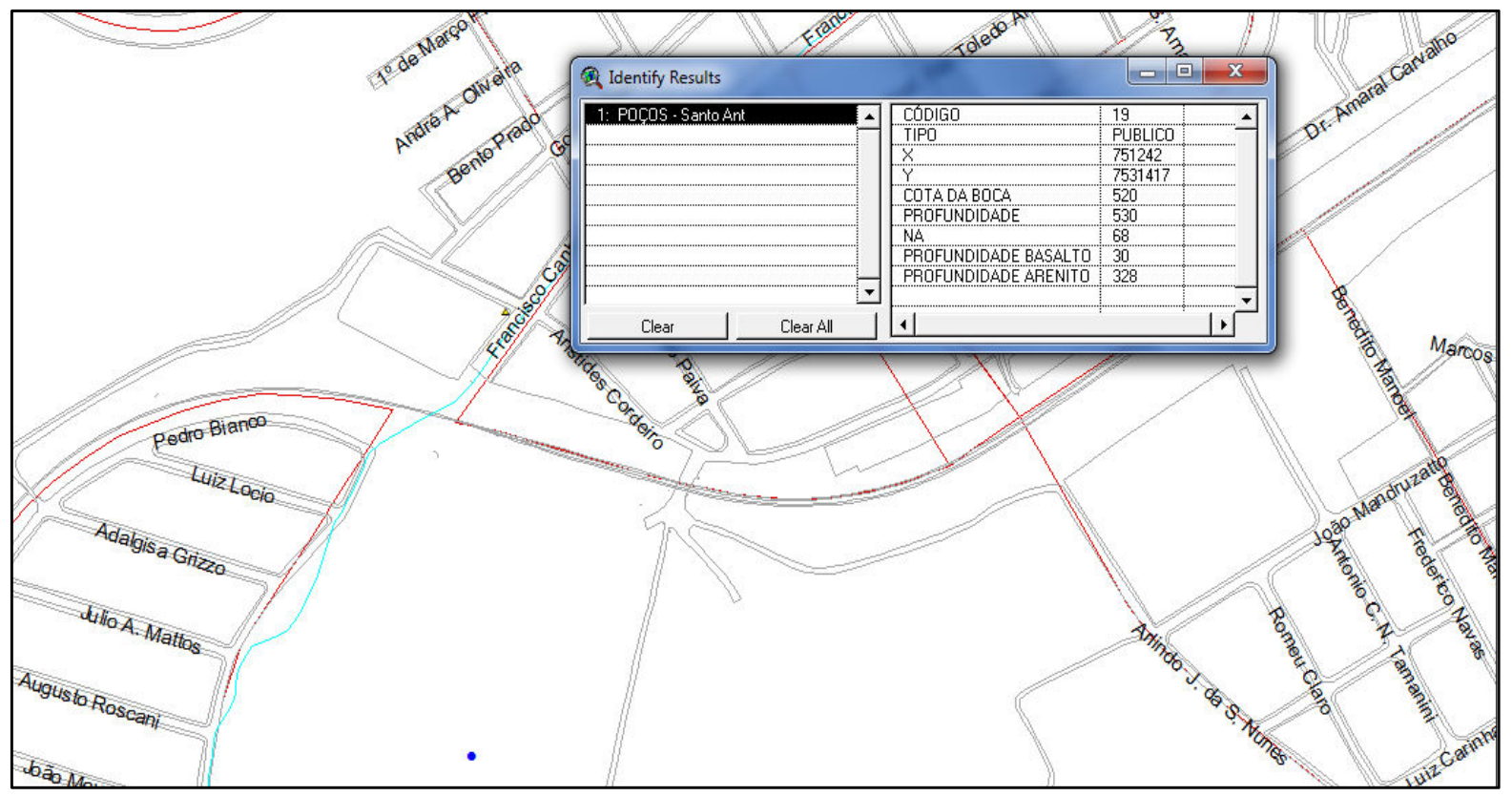

Figura 6.11: Exemplo de poço tubular profundo

Tabela 6.8: Relação das informações de poços de observação

\begin{tabular}{|c|c|c|c|c|c|c|c|}
\hline NO & $x$ & $\mathbf{Y}$ & Altitude & PROF. & NA & BASALTO & ARENITO \\
\hline 01 & 752540 & 7533775 & 552 & 9 & & 8 & \\
\hline 02 & 752536 & 7533799 & 555 & 8 & & 8 & \\
\hline 03 & 752535 & 7533795 & 555 & 5 & & & \\
\hline 04 & 752547 & 7533775 & 552 & 5 & & & \\
\hline 05 & 752547 & 7533802 & 555 & 2 & & & \\
\hline 06 & 752545 & 7533802 & 555 & 2 & & & \\
\hline 07 & 752539 & 7533791 & 554 & 2 & & & \\
\hline 08 & 752531 & 7533790 & 554 & 2 & & & \\
\hline 09 & 752256 & 7532740 & 499 & 5 & & 5 & \\
\hline 10 & 752248 & 7532757 & 499 & 5 & & 4 & \\
\hline 11 & 752240 & 7532743 & 498 & 7 & & 5 & \\
\hline 12 & 752237 & 7532754 & 498 & 6 & & 5 & \\
\hline 13 & 752229 & 7532752 & 498 & 6 & & 5 & \\
\hline 14 & 750753 & 7531843 & 568 & 15 & & & \\
\hline 15 & 750750 & 7531842 & 568 & 5 & & & \\
\hline 16 & 750747 & 7531842 & 568 & 5 & & & \\
\hline 17 & 750744 & 7531855 & 568 & 2 & & & \\
\hline 18 & 750750 & 7531860 & 568 & 2 & & & \\
\hline 19 & 750748 & 7531863 & 568 & 5 & & & \\
\hline
\end{tabular}




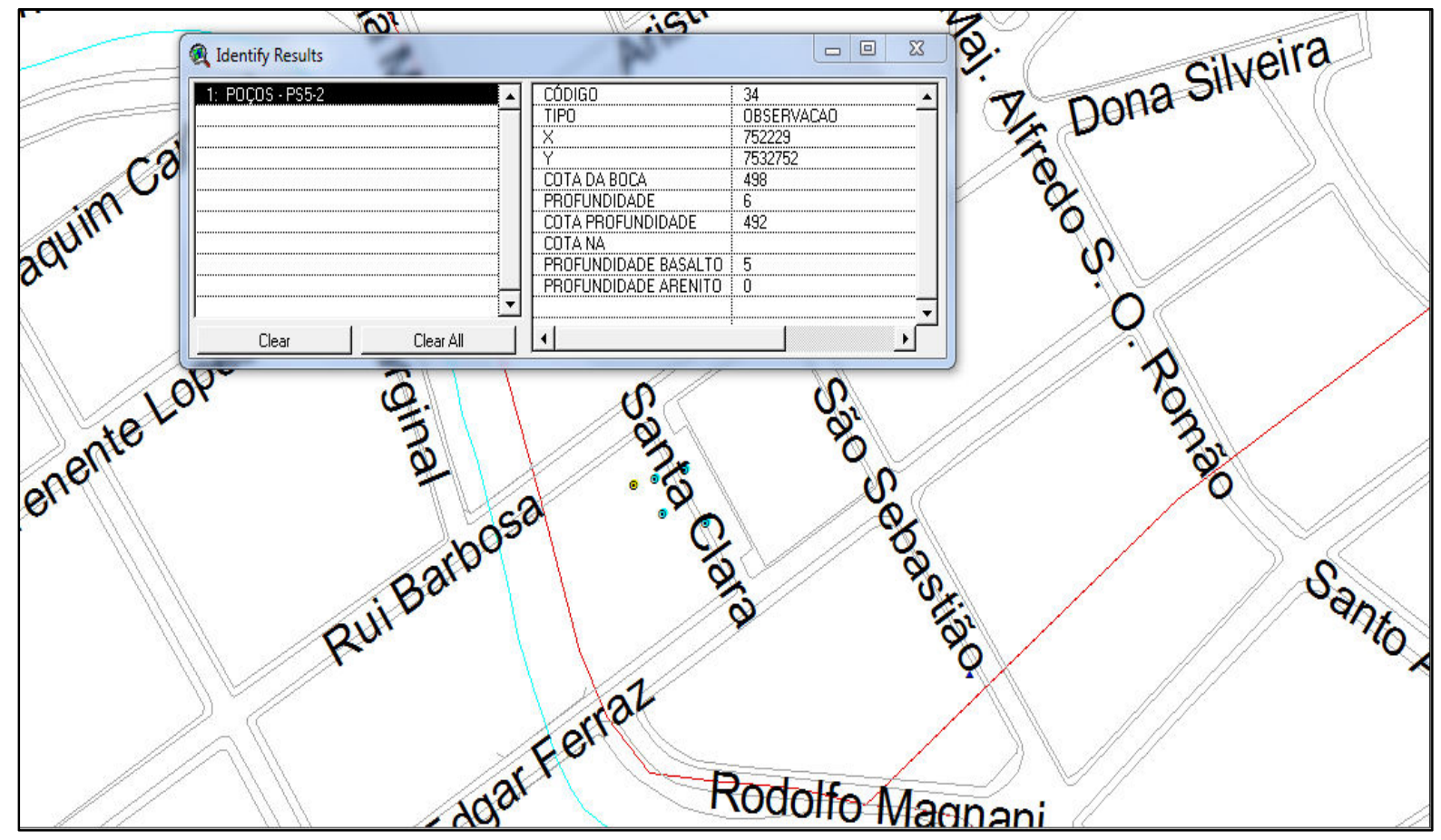

Figura 6.12: Exemplo de poço de observação

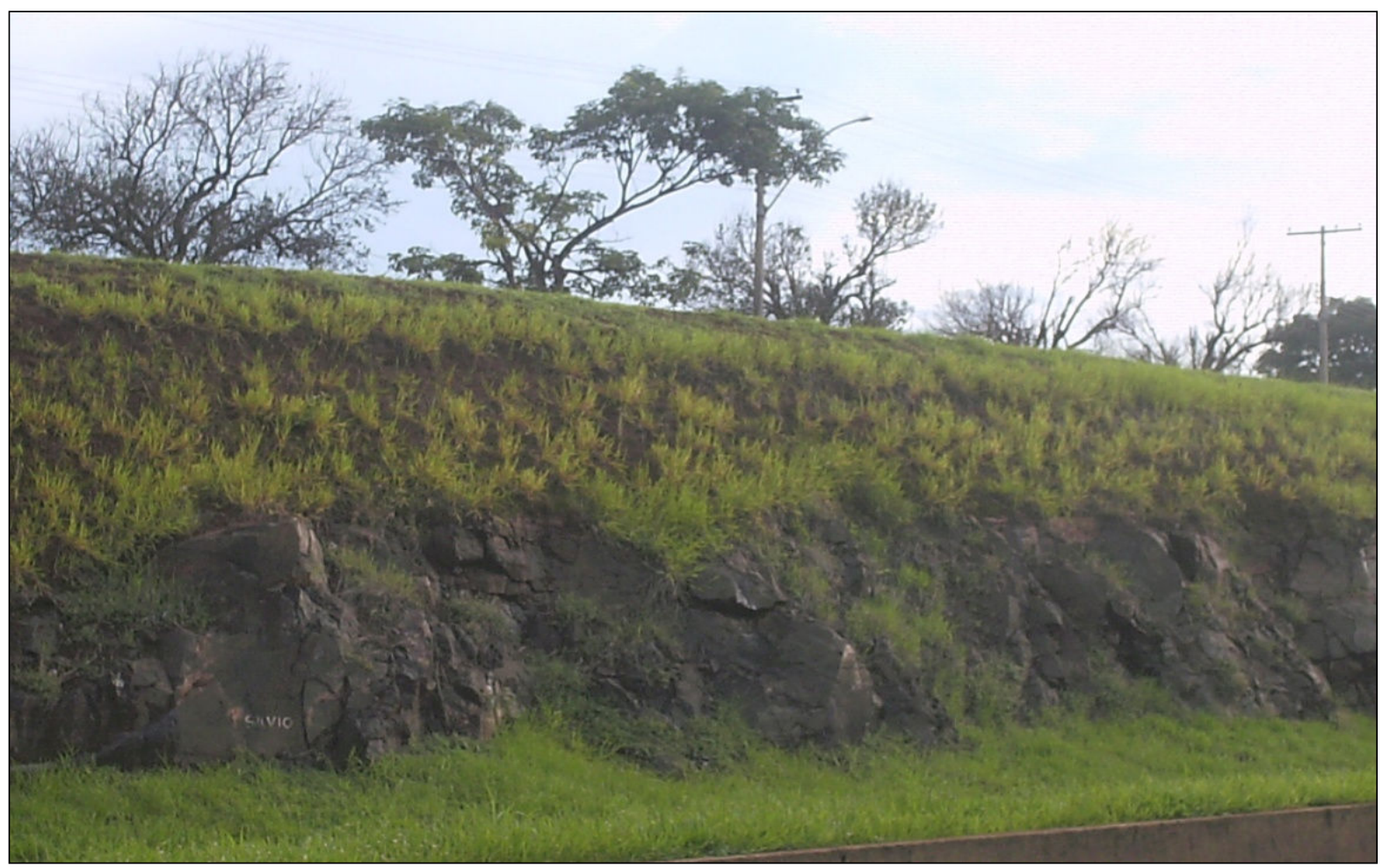

Figura 6.13: Afloramento rochoso na Rodovia Comandante Joao Ribeiro de Barros (SP 225) 
Tabela 6.9: Descrição dos afloramentos cadastrados

\begin{tabular}{ccccc}
\hline Afloramento & $\mathbf{X}$ & $\mathbf{Y}$ & Local & Profundidade (m) \\
\hline A1 & 749707,8 & 7534939,3 & Pedreira desativada & 1,5 \\
A2 & 749720,6 & 7534173,2 & Pedreira desativada & 2 \\
A3 & 753424,8 & 7532381,3 & Rodovia - SP225 & 3 \\
A4 & 756159,9 & 7532149,9 & RPPN - Morro & 3 \\
A5 & 755874,3 & 7532000,0 & RPPN- Estrada & 6 \\
A6 & 749752,0 & 7533734,3 & Pedreira desativada & 2,5 \\
\hline
\end{tabular}

\subsubsection{Mapa de Zoneamento}

O Mapa de Zoneamento trata das diretrizes para ocupação da área urbana e expansão urbana. Este Mapa apresenta 24 Zonas que trazem parâmetros quanto ao uso (residencial, comercial, industrial, institucional, cultural, etc.) e, quanto à ocupação do lote (taxa de ocupação, coeficiente de aproveitamento, altura da edificação, taxa de permeabilidade, recuos, etc.). A Figura 6.14 llustra um fragmento do Mapa de Zoneamento e no ANEXO A é apresentado o quadro síntese dos parâmetros de cada zona. 


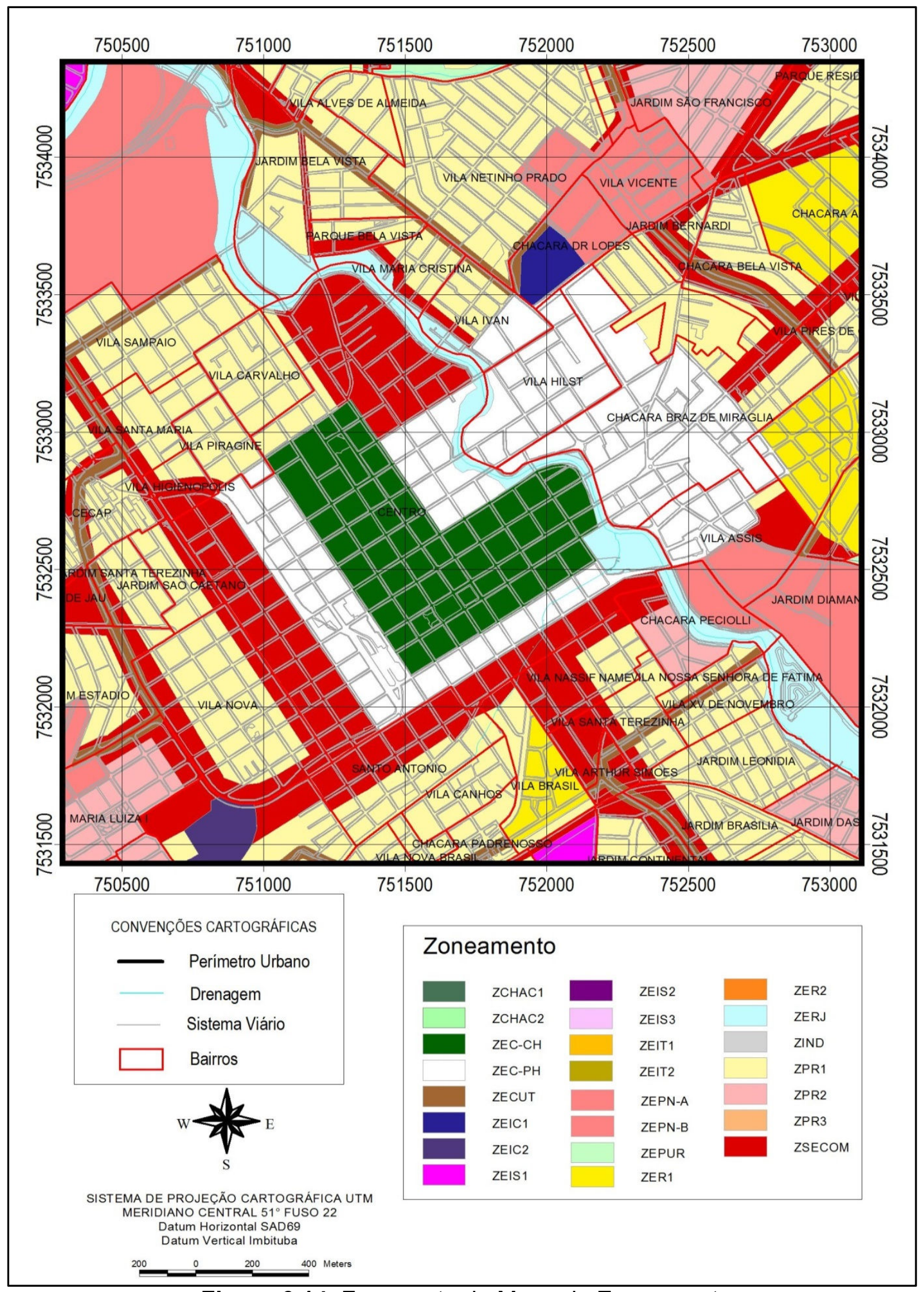

Figura 6.14: Fragmento do Mapa de Zoneamento 


\subsection{6 Áreas de Risco: erosões e inundações}

Os principais tipos de riscos geológico-geotécnicos presentes na área de estudo são as erosões pluviais e as inundações.

As erosões foram classificadas em erosões lineares e erosões laminares, e suas ocorrências delimitadas na base cartográfica, em três anos diferentes: 2001, 2005 e 2011, apenas no período de 2011 não houve ocorrências de erosões laminares.

Nas Tabelas 6.10 são apresentados os dados relativos as quantificações das erosões.

Tabela 6.10 Comprimento total das erosões lineares e área ocupada pelas erosões laminares

\begin{tabular}{ccc}
\hline ANO & $\begin{array}{c}\text { Erosão linear } \\
\mathbf{( k m )}\end{array}$ & $\begin{array}{c}\text { Erosão laminar } \\
\mathbf{( k m}^{\mathbf{2}} \mathbf{)}\end{array}$ \\
\hline 2001 & 1,7 & 0,004 \\
2005 & 2,9 & 0,03 \\
2011 & 1,7 & Sem registrado \\
\hline
\end{tabular}

As inundações foram levantadas de 2006 até 2011, há alguns pontos que sofreram processo de inundação apenas em um ano, mas há locais, como por exemplo, a área central na Rua Quintino Bocaiúva, que foi afetada por inundações todos os anos.

O Mapa da Figura 6.15 ilustra os locais com problemas de inundações, ilustrando os números de ocorrências no período de 2006 a 2011 . A Figura 6.16 apresenta o fragmento do Mapa de Áreas de Risco. As Figuras 6.17 e 6.18 mostram voçoroca e local com inundação, respectivamente. 


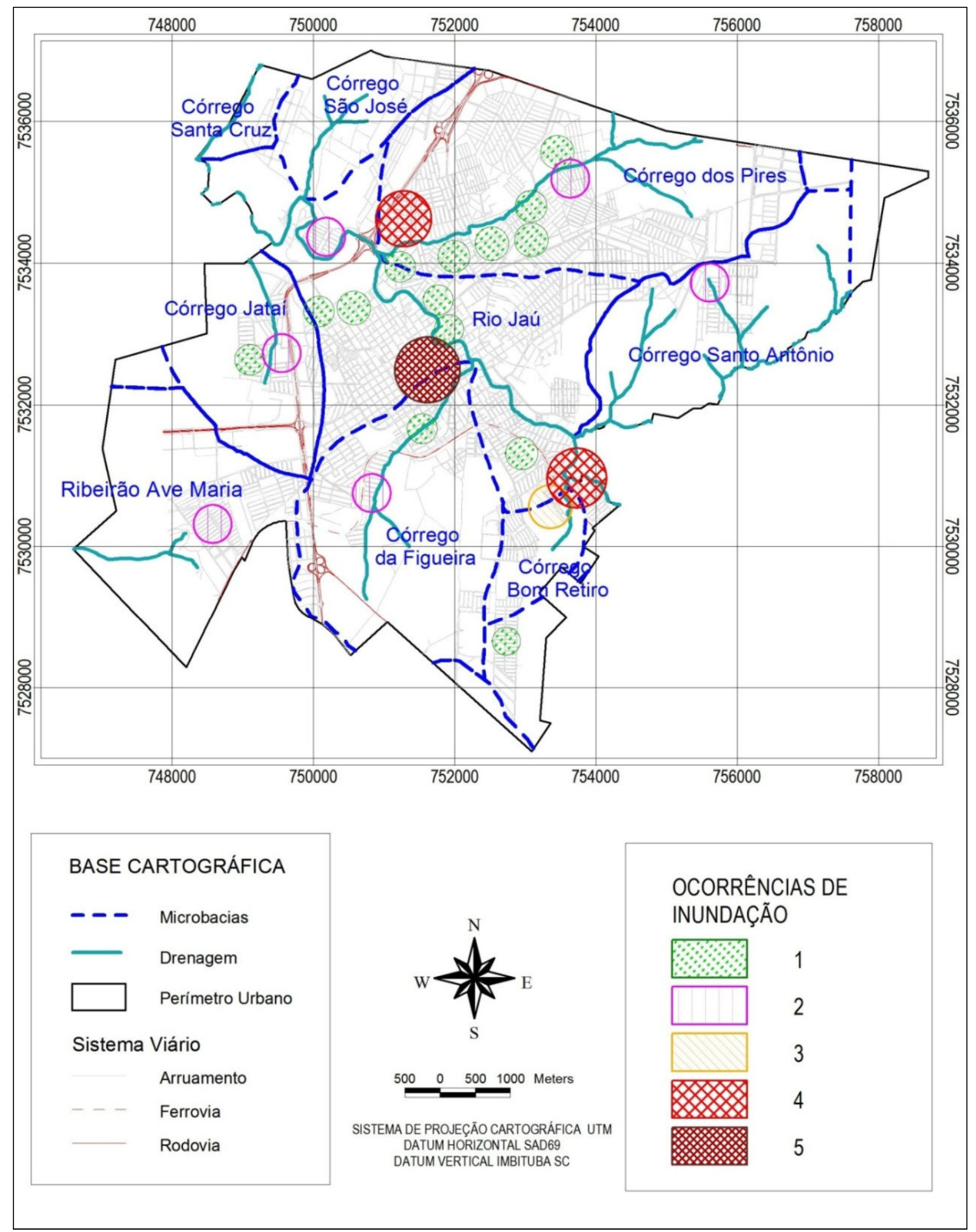

Figura 6.15: Ocorrências de inundações entre 2006-2011 (ROLLEMBERG et. al. 2011) 


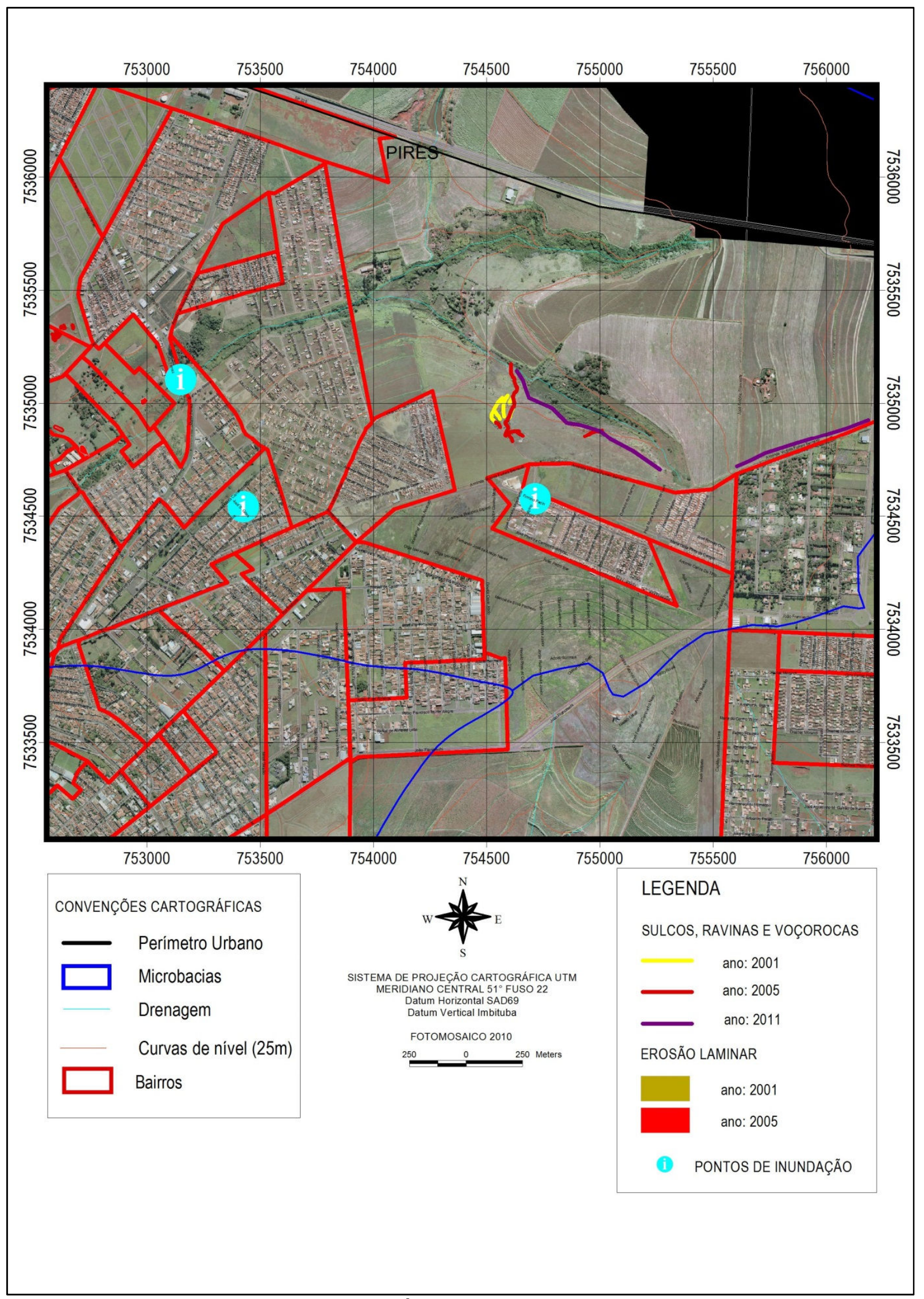

Figura 6.16: Mapa de Áreas de Risco - escala 1:25.000 


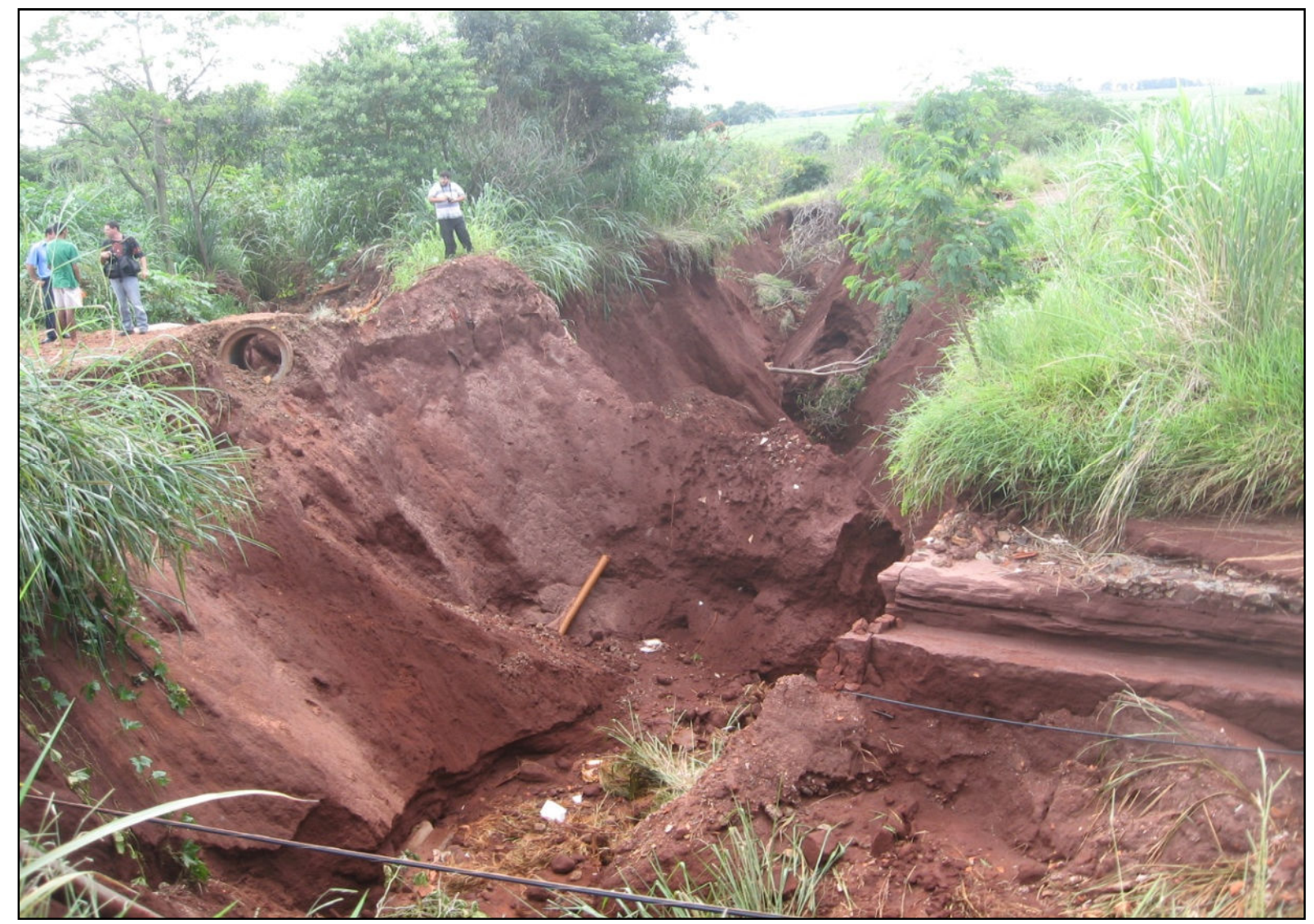

Figura 6.17: Voçoroca na Bacia do Córrego dos Pires em 2011.

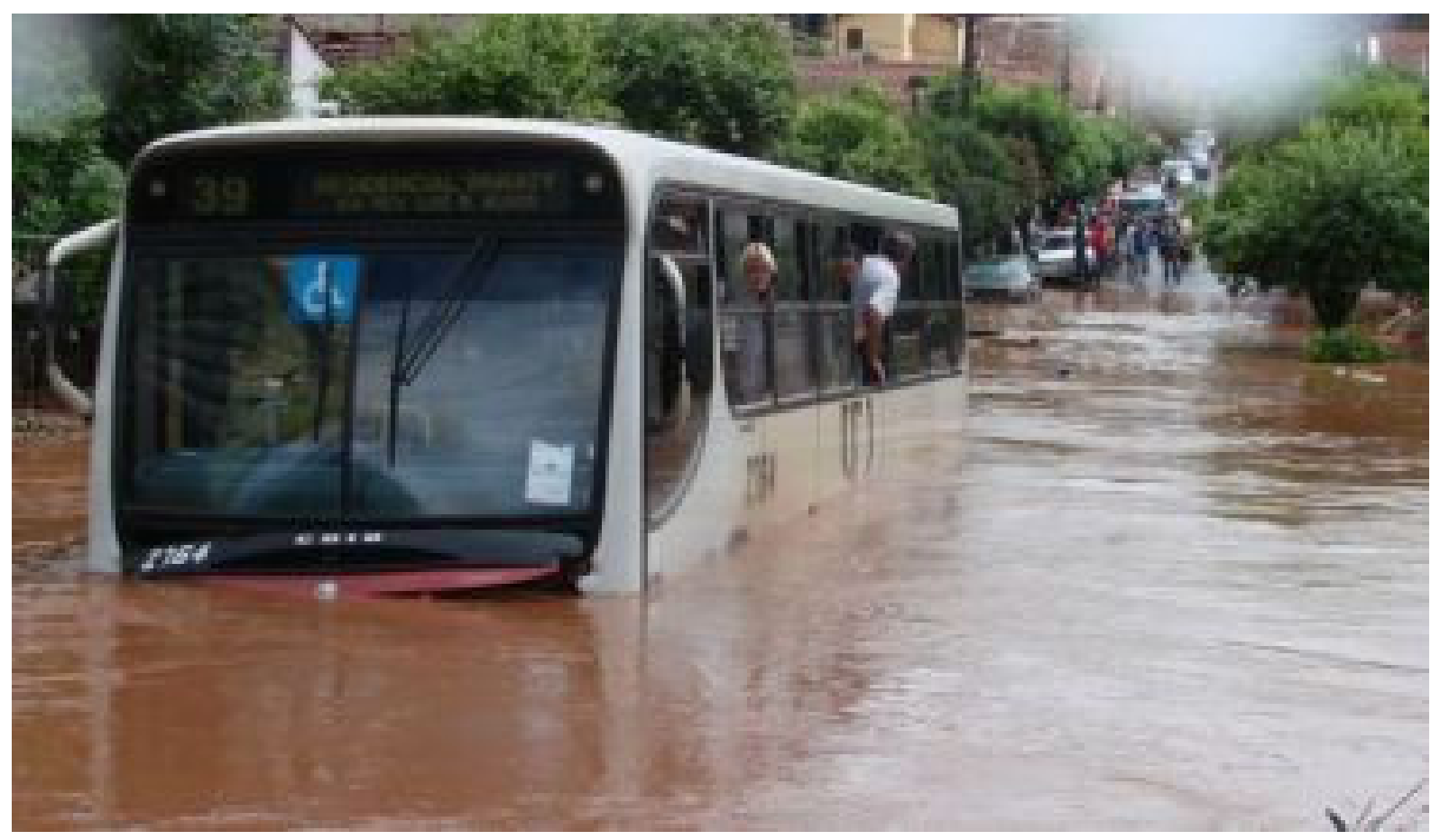

Figura 6.18: Local de Inundação na Área Central em 15 de novembro de 2011 


\subsection{7 Áreas de Proteção Ambiental}

As áreas de proteção ambiental são representadas pelas zonas ZEPUR e ZERJ, e ainda pela Reserva Ambiental RRPN Amadeu Botelho. Na Tabela 6.11 são apresentadas as áreas ocupadas por cada zona na área de estudo.

A Figura 6.19 traz uma fotografia da RPPN Amadeu Botelho. Na Figura 6.20 é apresentado o fragmento do Mapa de Áreas de Preservação Ambiental.

Tabela 6.11: Percentagem de distribuição das áreas de preservação ambiental

\begin{tabular}{ccc}
\hline $\begin{array}{c}\text { ÁREA DE } \\
\text { PROTEÇÃO }\end{array}$ & Área $\left(\mathbf{k m}^{2}\right)$ & $\begin{array}{c}\text { \% da área } \\
\text { total }\end{array}$ \\
\hline ZEPUR & 3,909 & 1,46 \\
ZERJ & 1,295 & 0,48 \\
RPPN & 1,875 & 0,70 \\
\hline TOTAL & 7,079 & 2,64 \\
\hline
\end{tabular}

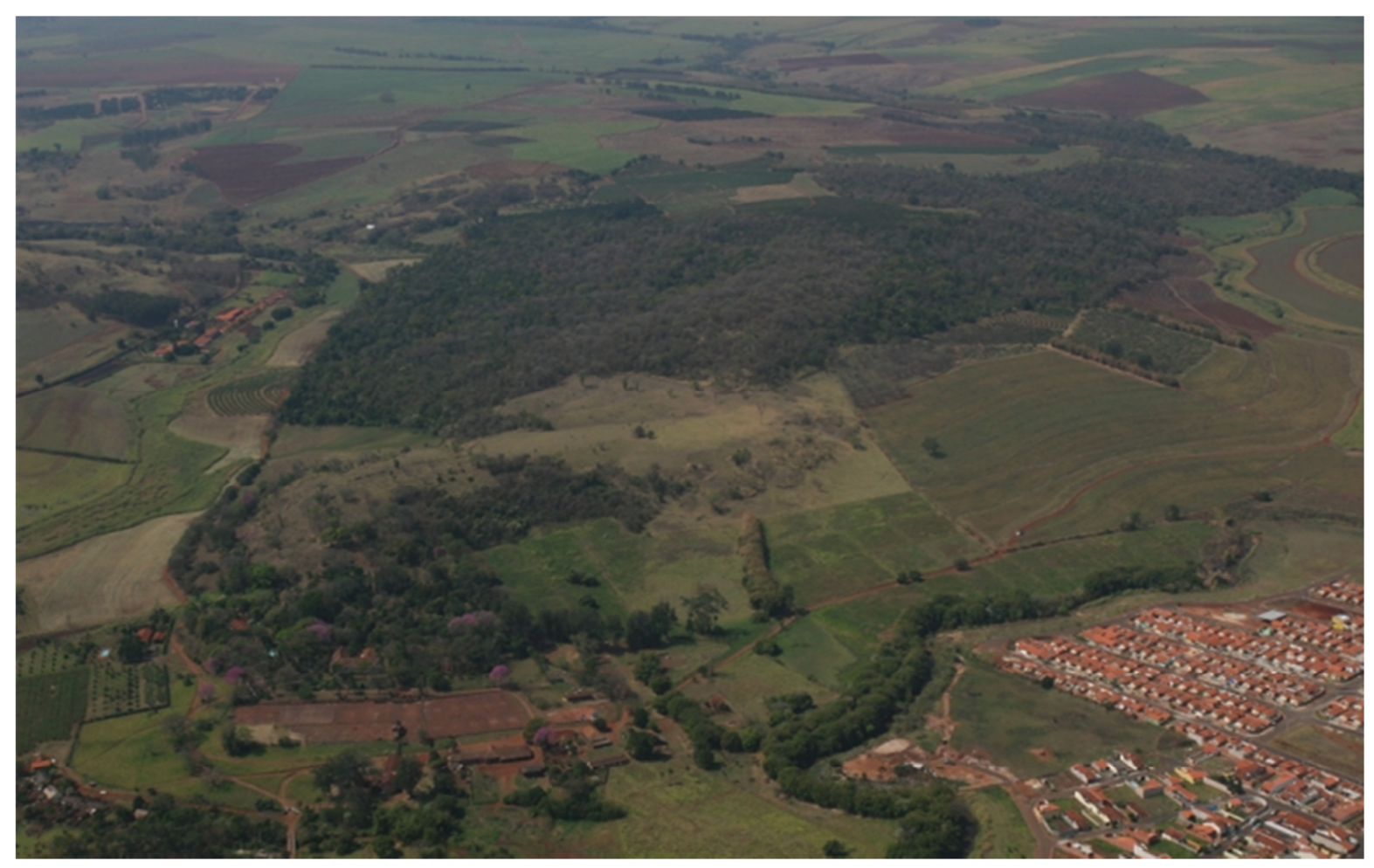

Figura 6.19: Vista área da RPPN - Amadeu Botelho (foto cedida pela Fatec-Jahu) 


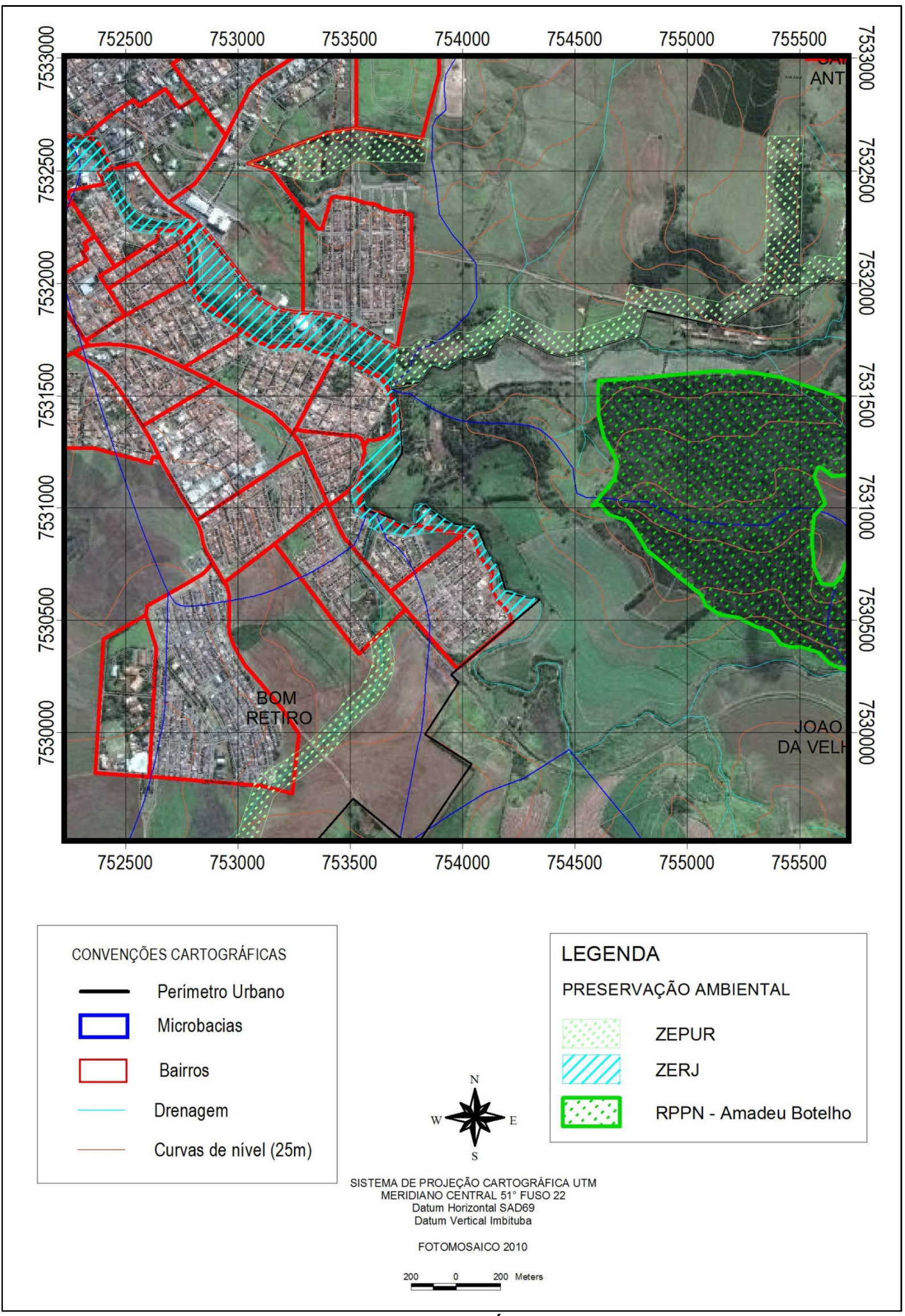

Figura 6.20: Fragmento do Mapa de Áreas de Proteção Ambiental 


\subsubsection{Infraestrutura Urbana e Dados Censitários}

As informações de infraestrutura urbana são descritas na Tabela 6.12. Na Figura 6.21 é apresentado um exemplo da tela do programa com a visualização das informações do tema rede de abastecimento de água.

Os dados censitários foram descritos por setor, sendo ao todo 208 setores censitários com 114.247 pessoas recenseadas na área urbana, totalizando uma área de $34,4 \mathrm{~km}^{2}$. A Figura 6.22 ilustra um exemplo de pesquisa por setor censitário.

Tabela 6.12: Dados de infraestrutura urbana inseridos na base.

\begin{tabular}{llc}
\hline \multicolumn{1}{c}{ Arquivo } & \multicolumn{1}{c}{ Informações } & Cedido/Executado \\
\hline $\begin{array}{l}\text { Rede de abastecimento } \\
\text { de água }\end{array}$ & $\begin{array}{l}\text { Linha de abastecimento } \\
\text { dos reservatórios até } \\
\text { residências. }\end{array}$ & SAEMJA - Jaú \\
$\begin{array}{l}\text { Rede de coleta de } \\
\text { esgoto }\end{array}$ & $\begin{array}{l}\text { Linha de coleta das } \\
\text { residências até as as } \\
\text { elevatórias daí para ETE. }\end{array}$ & SAEMJA - Jaú \\
\hline
\end{tabular}

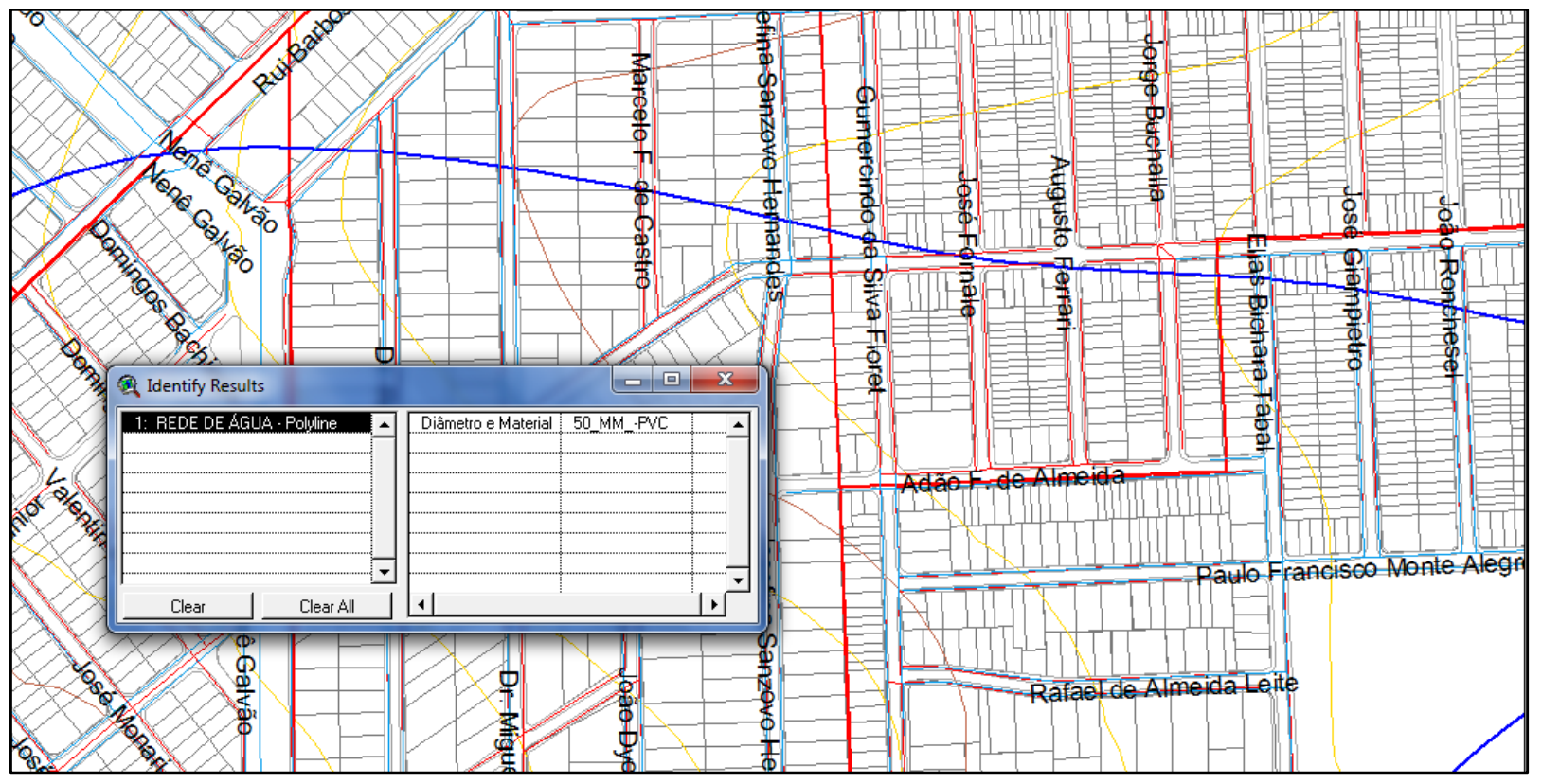

Figura 6.21: Exemplo de identificação de rede de água tubo de 50mm em PVC 


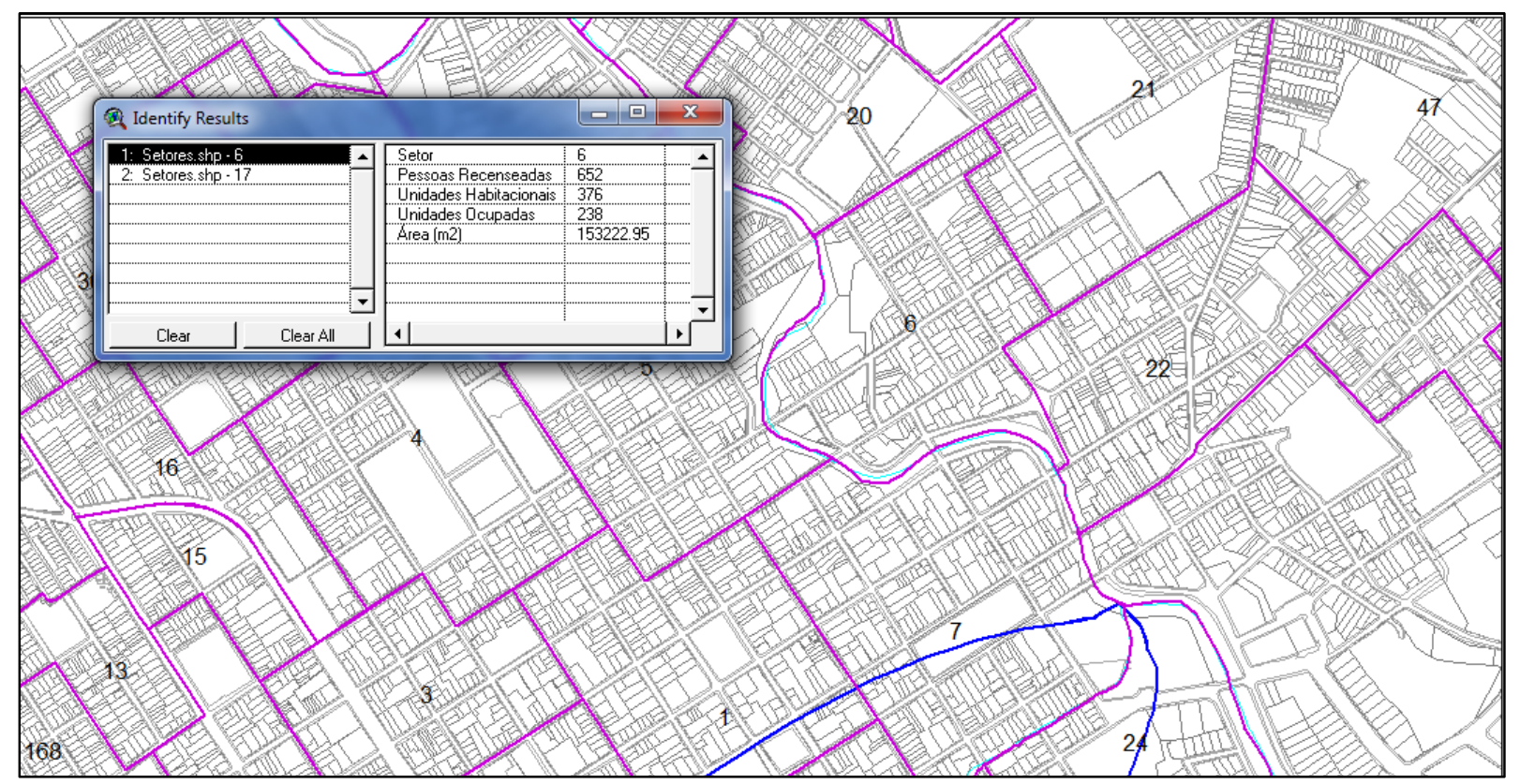

Figura 6.22: Exemplo de informações por setor censitário

\subsubsection{Patrimônio Histórico}

A classificação dos imóveis de valor histórico referiu-se exclusivamente ao seu grau de tombamento, para que seja facilitada as analises quanto a projetos de reformas e alvarás de funcionamento. Os imóveis tombados têm quatro graus de preservação:

Grau 1: Aplicável aos imóveis e bens tombados de alto valor histórico, arquitetônico e ambiental, determinando que: a preservação das edificações seja integral, a utilização do imóvel tenha funções compatíveis com sua preservação e sejam aplicados métodos adequados em sua conservação e restauração.

Grau 2: Aplicável aos imóveis e bens tombados de valor histórico, arquitetônico e ambiental, e cuja importância não abranja a totalidade do bem, determinando que: a preservação se refira apenas a partes delimitadas do imóvel como a fachada, os caixilhos, a volumetria, unidade de pintura externa e caso haja relevância a pintura interna, a utilização do imóvel não degrade a parte protegida e sejam aplicados métodos adequados em sua conservação e restauração; 
Grau 3: Aplicável aos imóveis e bens tombados de valor histórico, arquitetônico e ambiental, e cujo principal valor resida nas características externas, que somente a proteção da fachada seja suficiente para assegurar a preservação dos valores, determinando que: a preservação se refira a conservação das fachadas, componentes externos, aberturas, ornamentos e pintura, as edificações poderão sofrer alterações na parte interna e sejam aplicados métodos adequados em sua conservação e restauração;

Grau 4: aplicável para imóveis com características singelas e que não faz parte de fatos de grande importância histórica, sendo preservados através de fotos, vídeos, croquis, projetos arquitetônicos, relatos e documentos.

A grande maioria dos imóveis tombados encontram-se na região central, apenas alguns distam no máximo $1 \mathrm{~km}$ da área central. As Figuras 6.23, 6.24 e 6.25 ilustram alguns exemplos de imóveis tombados. A Figura 6.26 mostra os imóveis tombados inseridos na base de dados do sistema.

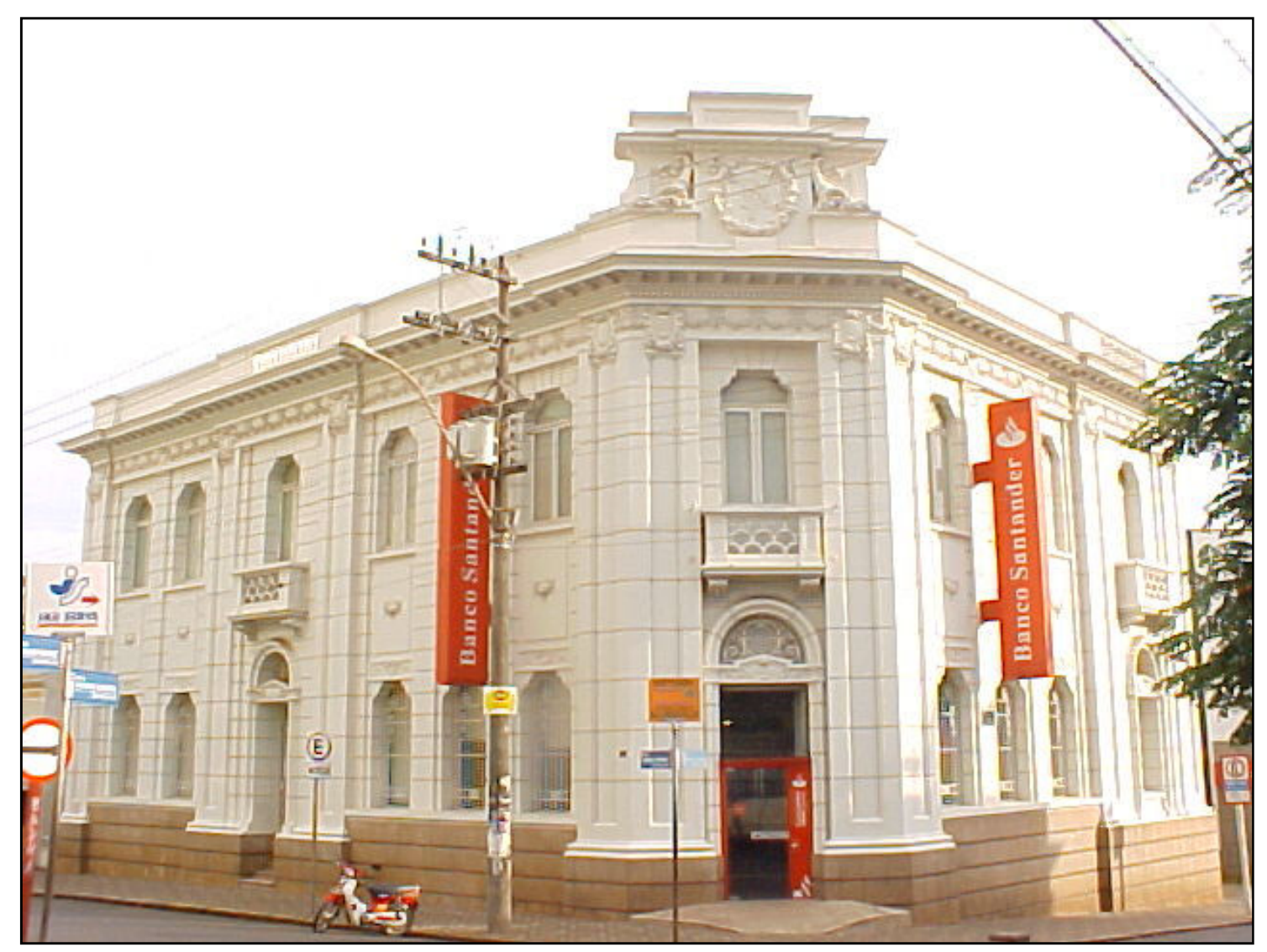

Figura 6.23: Exemplo de imóvel tombado com Grau de Preservação 1. 


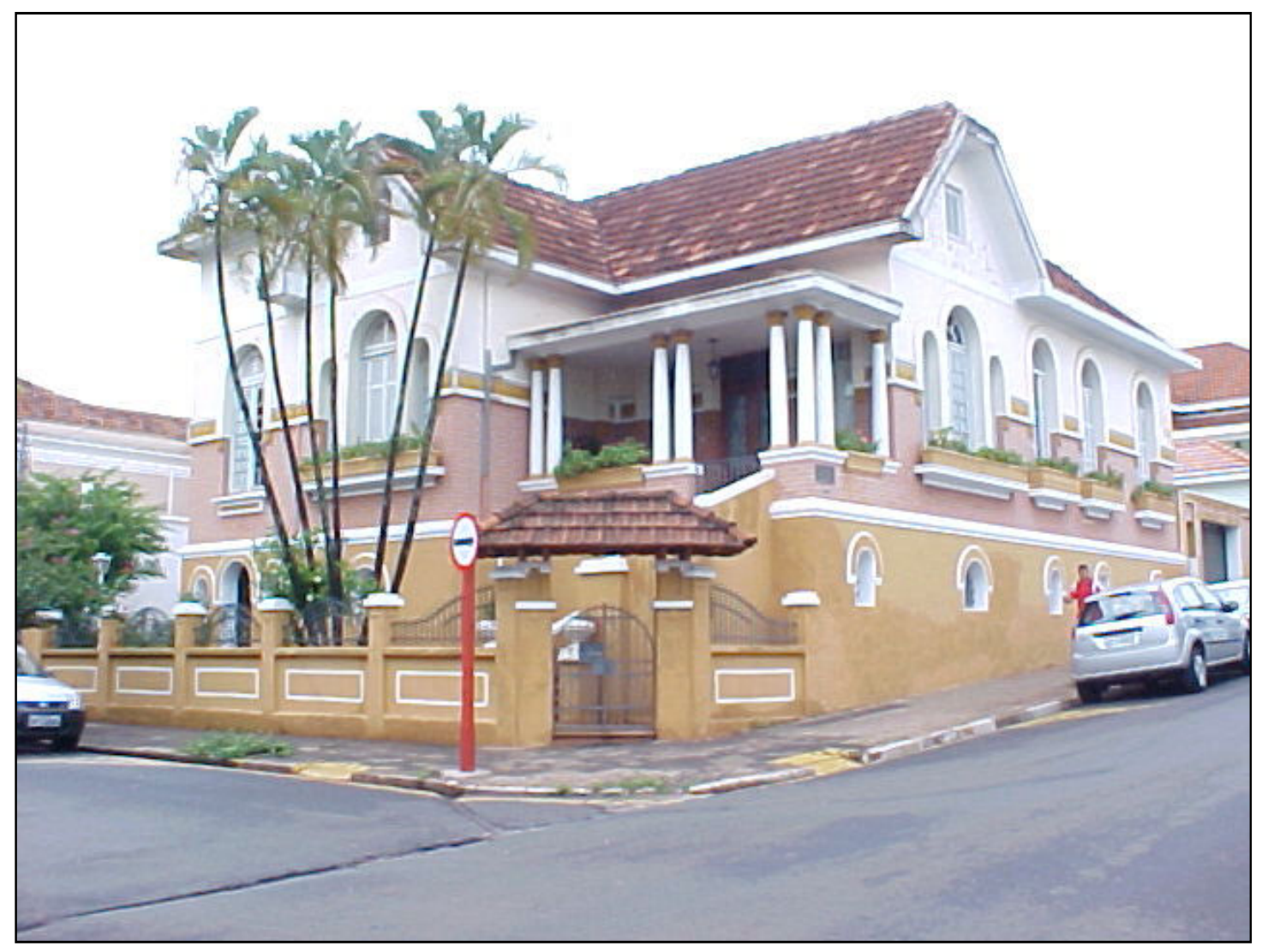

Figura 6.24: Exemplo de imóvel tombado com Grau de Preservação 2.

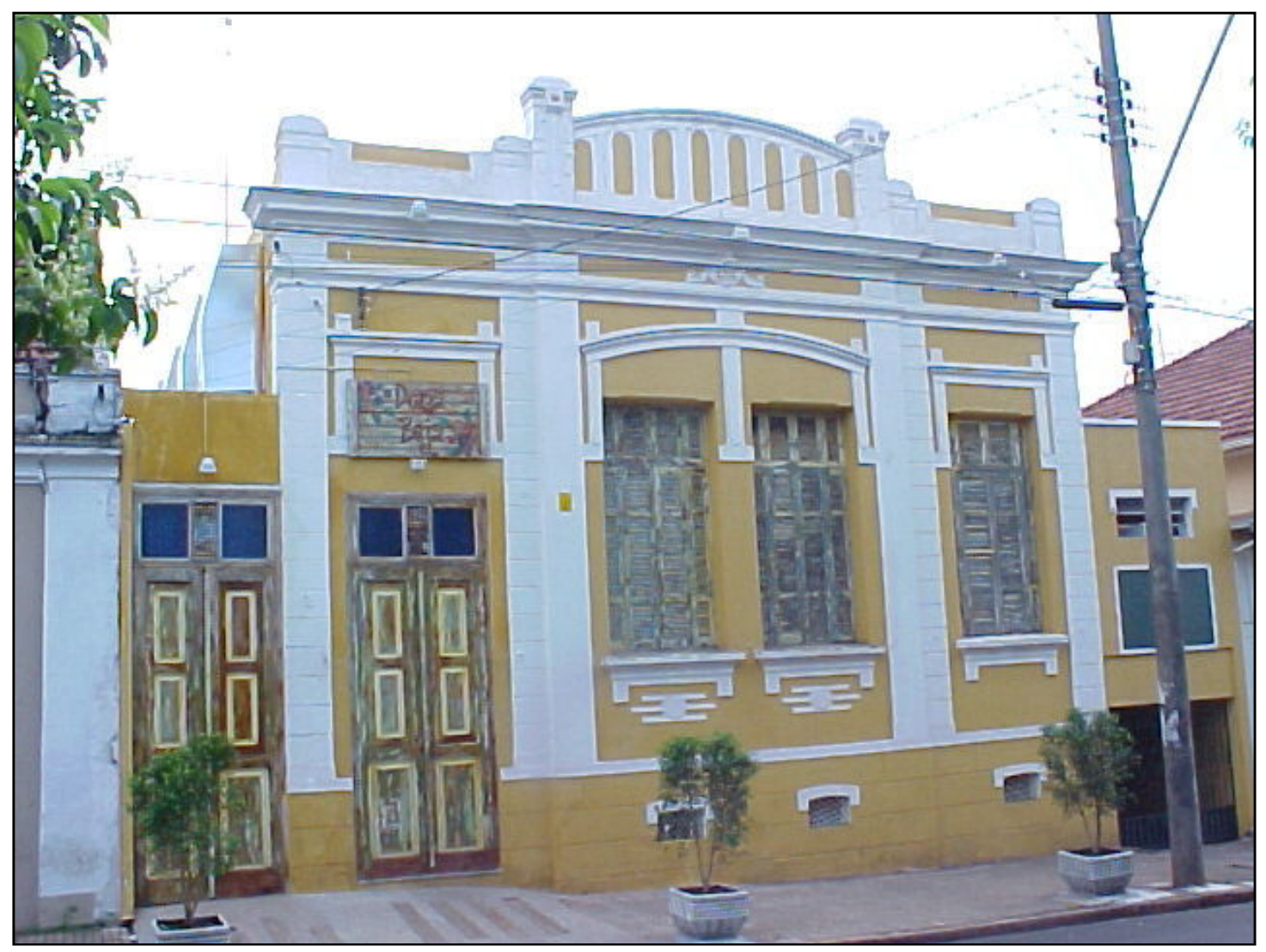

Figura 6.25: Exemplo de imóvel tombado com Grau de Preservação 3. 


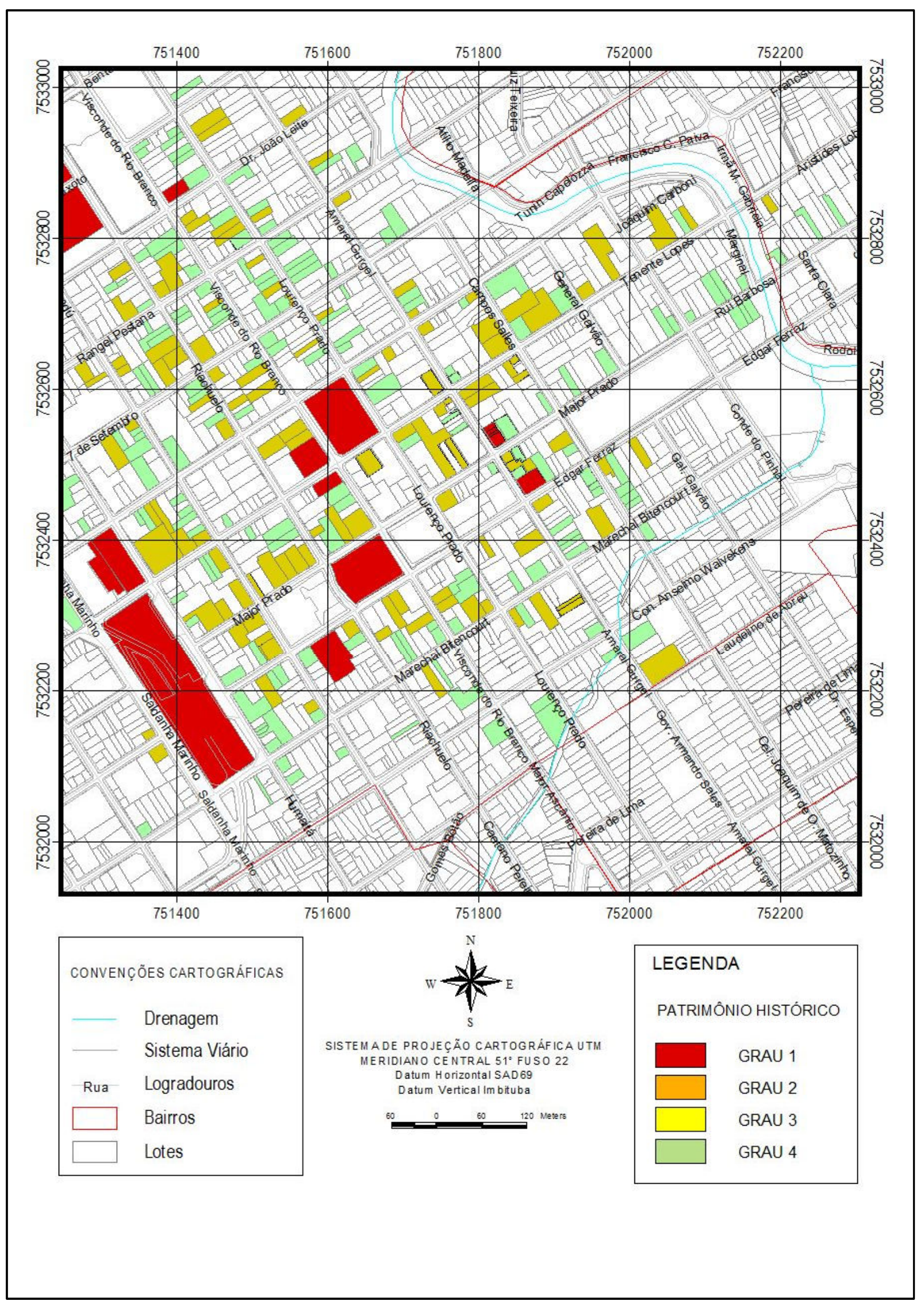

Figura 6.26: Exemplo da demarcação de imóveis tombados 


\subsection{Sistema de Apoio a Gestão Urbana}

A construção do sistema foi baseada nas funções estabelecidas para os usuários da gestão pública.

A Figura 6.27 apresenta um diagrama com os objetivos propostos para o sistema, agrupados pelas análises e tarefas, pelos produtos finais pretendidos e pelos usuários potenciais do sistema.

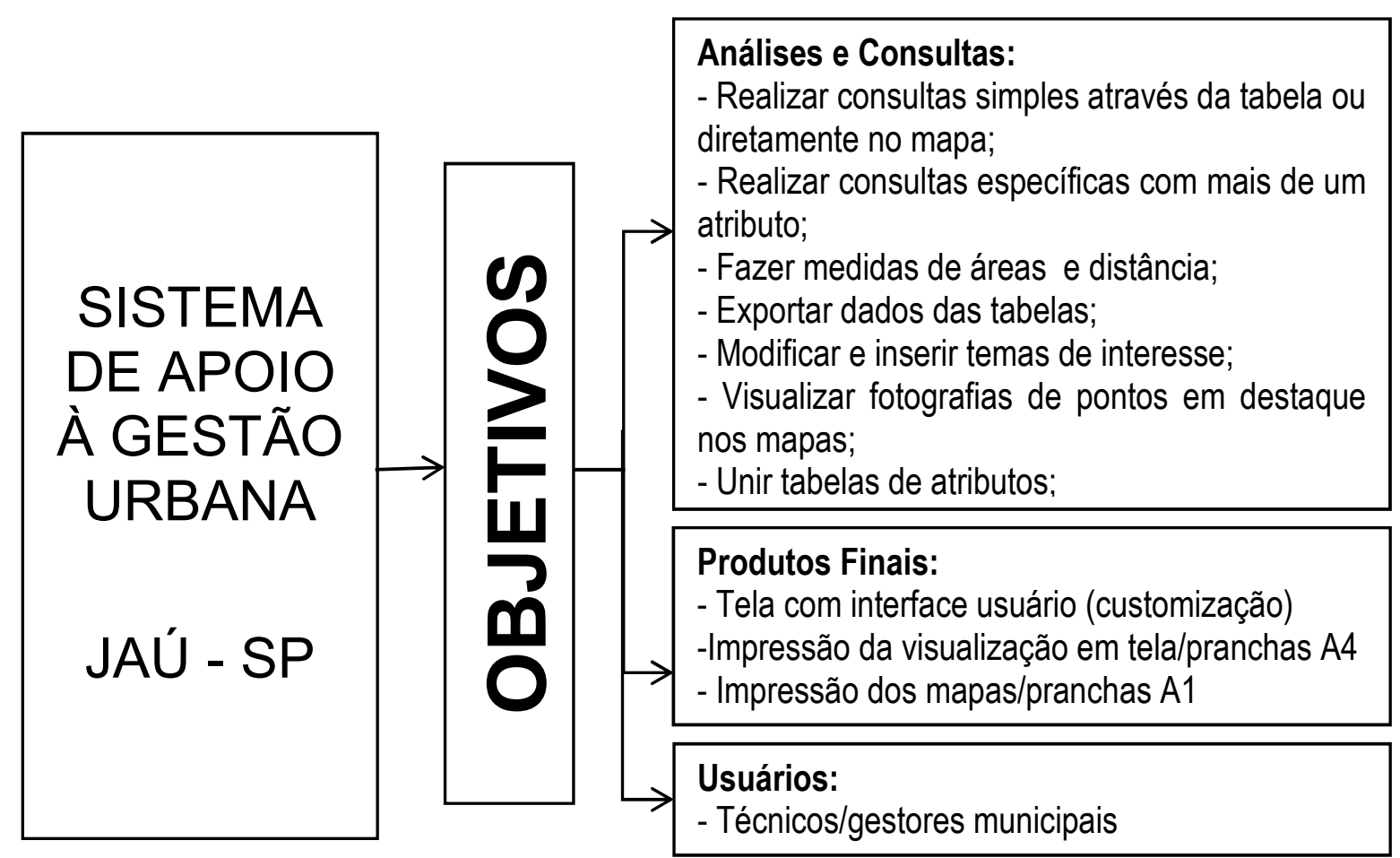

Figura 6.27: Objetivos propostos para o Sistema.

\subsubsection{Estruturação do Sistema}

O sistema foi composto por seis módulos, que tratam de assuntos relacionados à gestão urbana. Na Figura 6.28 é apresentado um fluxograma que contém os seis módulos e as funções do sistema. Em cada módulo foram 
disponibilizados temas relacionados entre si, tais temas são apresentados na Figura 6.29 distribuídos nos seis módulos.

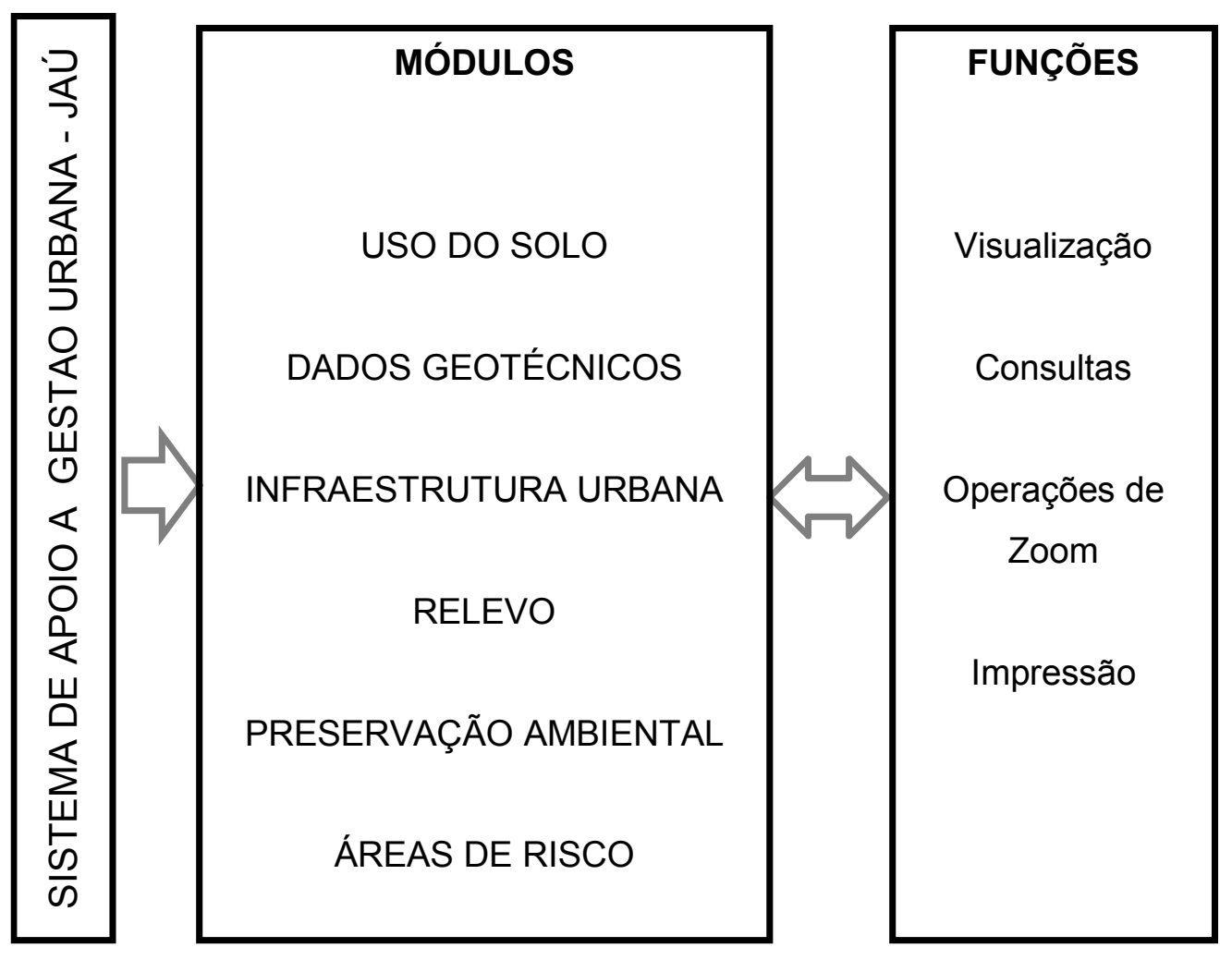

Figura 6.28: Estrutura lógica e funcional do sistema 


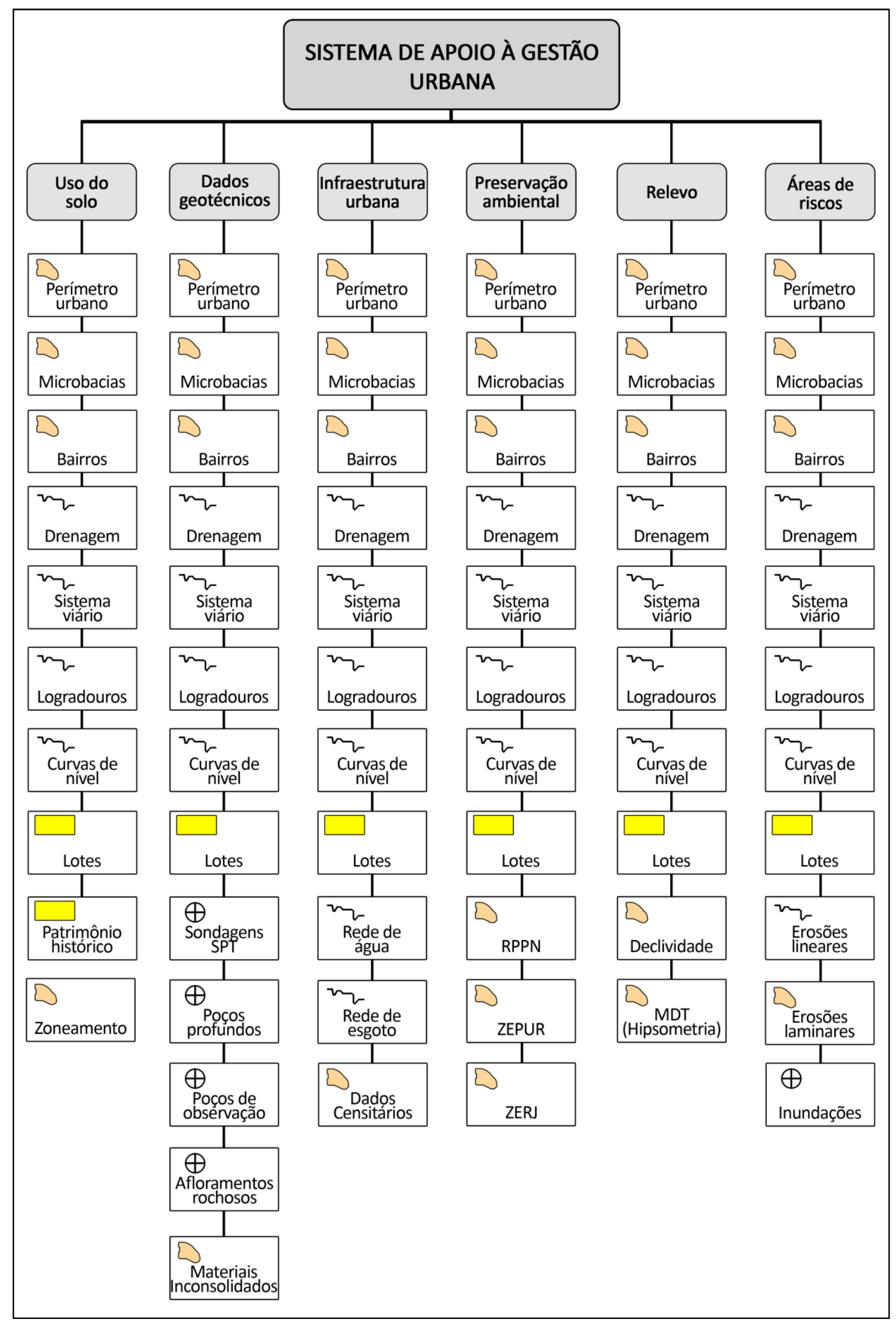

Figura 6.29: Temas dispostos em cada módulo do sistema 


\subsubsection{Customização}

A customização foi estabelecida de acordo com as funções disponibilizadas para os usuários da prefeitura municipal.

Todos os menus foram retirados, permanecendo apenas os ícones com as ações definidas para o sistema. A tela inicial do sistema apresenta o projeto, os ícones de entrada para cada módulo e os ícones das impressões em formato A1 e A4 (Sistema Internacional - SI) para cada módulo.

As funções de cada ícone apresentado na tela inicial são descritos na Tabela 6.13 e a Figura 6.30 mostra a tela de abertura do Sistema de Gestão Urbana.

Tabela 6.13: Tabela de ícones presentes na tela inicial do projeto

\begin{tabular}{|c|c|c|}
\hline Ícone & Função & Descrição \\
\hline $8 \Rightarrow$ & Abrir Capa do projeto & Abre a tela de visualização da capa do projeto \\
\hline 1 & Abrir Módulo 1 & Abre a tela de visualização do view: Uso do Solo \\
\hline 2 & Abrir Módulo 2 & Abre a tela de visualização do view: Dados Geotécnicos \\
\hline 3 & Abrir Módulo 3 & Abre a tela de visualização do view: Infraestrutura Urbana \\
\hline 4 & Abrir Módulo 4 & Abre a tela de visualização do view: Relevo \\
\hline 5 & Abrir Módulo 5 & $\begin{array}{l}\text { Abre a tela de visualização do view: Preservação } \\
\text { Ambiental }\end{array}$ \\
\hline 6 & Abrir Módulo 6 & Abre a tela de visualização do view: Áreas de Risco \\
\hline A1 & Abrir Layout A1 & $\begin{array}{l}\text { Abre a tela de impressão em formato A1 para o Módulo } \\
\text { onde o ícone está posicionado }\end{array}$ \\
\hline A4 & Abrir Layout A4 & $\begin{array}{l}\text { Abre a tela de impressão em formato A4 para o Módulo } \\
\text { onde o ícone está posicionado }\end{array}$ \\
\hline
\end{tabular}




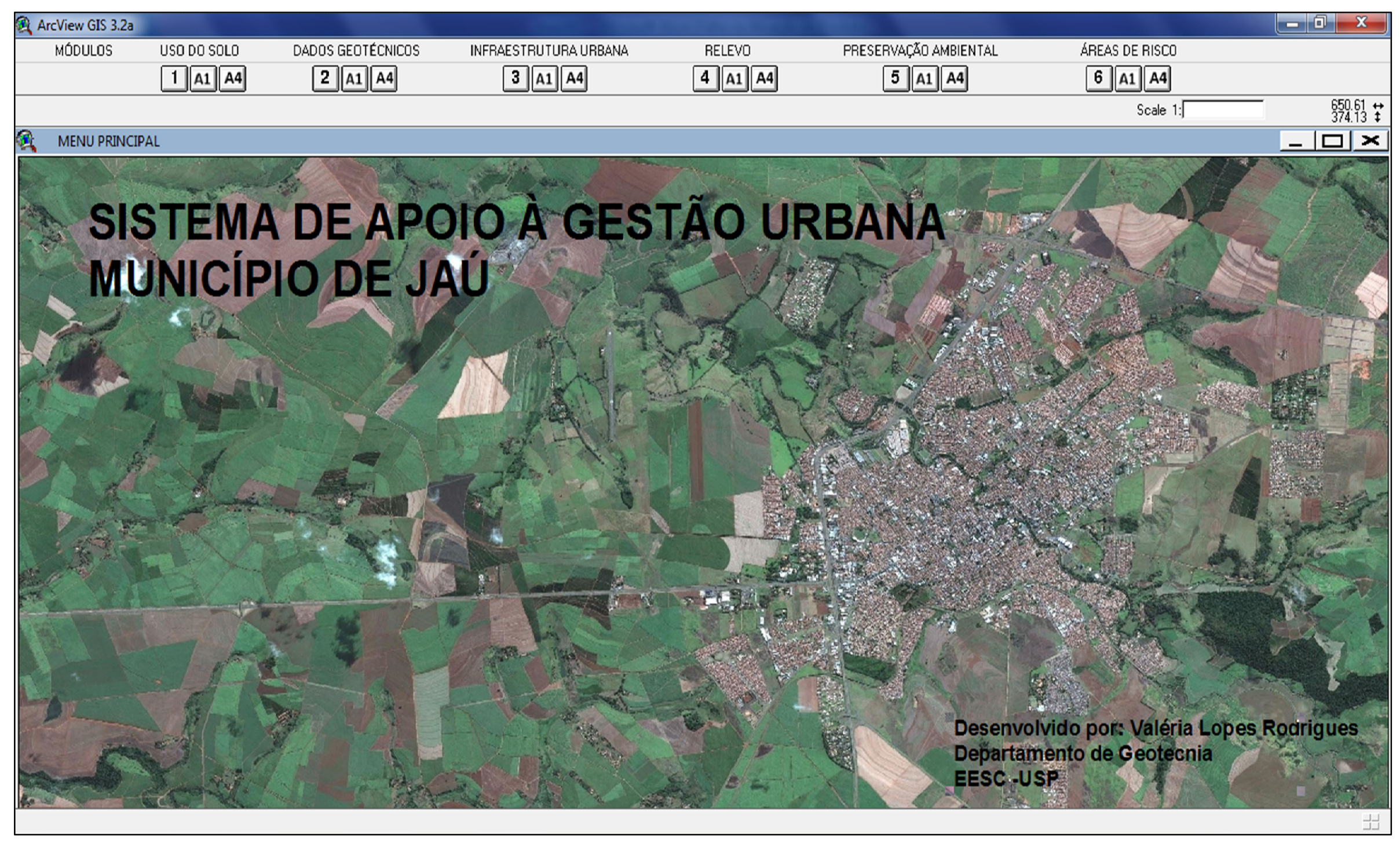

Figura 6.30: Tela de abertura do Sistema de Apoio à Gestão Urbana. 
Os módulos apresentam algumas funções específicas para consulta e seleções que são realizadas através dos botões As telas de cada módulo apresentam os temas relacionados a este módulo, onde poderão ser feitas as consultas e visualizações. A Figura 6.31 apresenta um exemplo que ficam na parte superior da tela. Na Tabela 6.14 são listados os botões e suas funções dentro do módulo.

Tabela 6.14: Tabela de ícones presente em cada view

\begin{tabular}{|c|c|c|}
\hline Ícone & Função & Descrição \\
\hline $\mathbf{t}$ & Inserir tema & Insere novo tema em formato shape ou $d x f$ \\
\hline$+\not{B}$ & Apagar Tema & Apaga o tema selecionado \\
\hline 酔 & Abrir Tabela & Abre a tabela de atributos do tema ativo \\
\hline A & Buscar & Busca por atributos no tema ativo \\
\hline 曾 & Cálculo de área & Calcula a área de polígonos no tema ativo \\
\hline & Selecionar no mapa & Seleciona elementos no mapa através do cursor \\
\hline & Construir consulta & $\begin{array}{l}\text { Permite montar uma equação para seleção através de um } \\
\text { ou mais atributos no tema ativo. }\end{array}$ \\
\hline & Limpar consulta & Limpa as consultas realizadas no tema ativo \\
\hline & Zoom View & Zoom estendido ao view \\
\hline & Zoom Tema & Zoom estendido ao tema ativo \\
\hline & Zoom da seleção & Zoom do atributo selecionado no tema ativo \\
\hline & Voltar Zoom & Retorna ao Zoom anterior \\
\hline & Distância & $\begin{array}{l}\text { Possibilita medir uma dada distância linear na tela através } \\
\text { do cursor }\end{array}$ \\
\hline 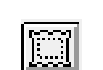 & Fotografia & Apresenta fotografias de determinados pontos no mapa \\
\hline (i) & Informações & $\begin{array}{l}\text { Mostra as informações contidas na tabela de atributos para } \\
\text { o objeto selecionado }\end{array}$ \\
\hline$-1-1$ & Selecionar & Seleciona vários atributos no mapa através do cursor. \\
\hline$\oplus$ & Aumentar Zoom & $\begin{array}{l}\text { Aumenta a escala de visualização limitando-a a retângulo } \\
\text { desenhado com o auxilio do cursor }\end{array}$ \\
\hline$\Theta$ & Diminuir Zoom & $\begin{array}{l}\text { Diminui a escala de visualização posicionando o cursor e } \\
\text { clicando-se o mouse }\end{array}$ \\
\hline sin & Deslocar tela & $\begin{array}{l}\text { Desloca a visualização no sentido em que se deslocar o } \\
\text { cursor }\end{array}$ \\
\hline
\end{tabular}




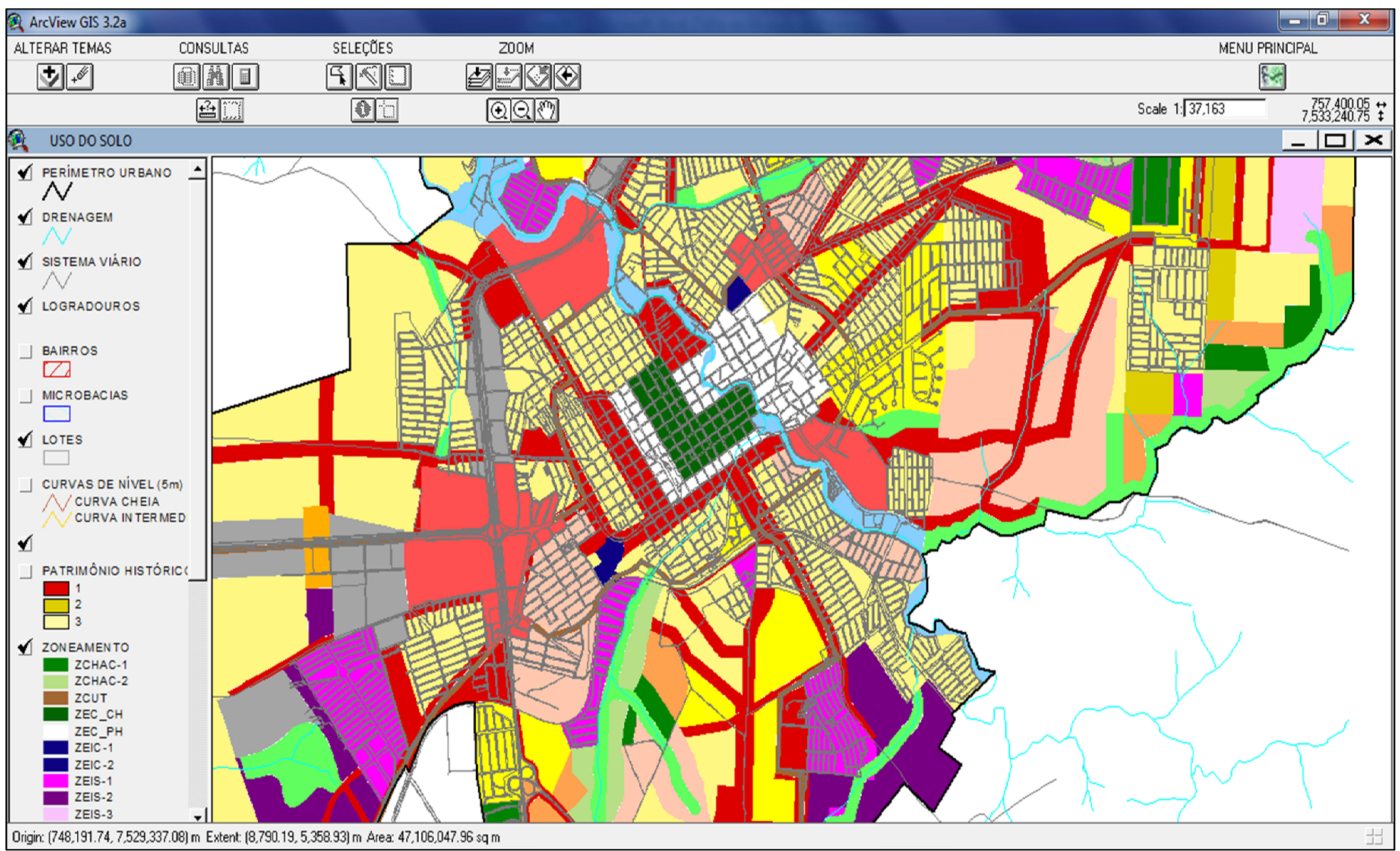

Figura 6.31: Exemplo da visualização da tela no Módulo 1 - Uso so Solo. 
Cada tema possui uma tabela de atributos, estas tabelas podem ser consultadas através das funções dos ícones disponibilizados, conforme descrito na Tabela 6.15. A Figura 6.32 mostra a tabela de atributos de poços de tubulares profundos.

Os layouts de impressão podem ser abertos através dos ícones na tela inicial do sistema, sendo possível a impressão em formatos A4 e A1 para cada módulo. Os layouts possuem também funções de zoom e a saída impressa.

No formato A4 é impresso a visualização na tela do módulo. O formato A1 foi fixado na escala de impressão 1:40.000, abrangendo a área de estudo inteira.

No Apêndice A1 e A2 são apresentados exemplo das impressões nos formatos $A 4$ e $A 1$, respectivamente.

A Figuras 6.33 apresenta a tela do layout. Na Tabela 6.16 são descritos os ícones localizados na área de trabalho dos layouts

Tabela 6.15: Tabela dos ícones presentes na tela de tabelas.

\begin{tabular}{|c|c|c|}
\hline Ícone & Função & Descrição \\
\hline 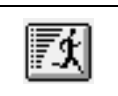 & Exportar dados & $\begin{array}{c}\text { Exportar os dados da tabela em uso nos formatos dbf, } \\
\text { INFO ou texto }\end{array}$ \\
\hline 国 & Selecionar tudo & Seleciona todos os atributos da tabela em uso \\
\hline & Limpar consulta & Limpa as consultas realizadas na tabela em uso \\
\hline 豓 & Promover & $\begin{array}{l}\text { Promove os atributos selecionados deixando os nas } \\
\text { primeiras linhas }\end{array}$ \\
\hline 訔 & Ordem decrescente & $\begin{array}{c}\text { Ordena os atributos da coluna selecionada na ordem } \\
\text { decrescente sem alteração as informações relacionadas } \\
\text { nas linhas }\end{array}$ \\
\hline & Ordem crescente & $\begin{array}{c}\text { Ordena os atributos da coluna selecionada na ordem } \\
\text { crescente sem alteração as informações relacionadas nas } \\
\text { linhas }\end{array}$ \\
\hline 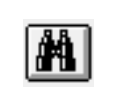 & Buscar & Busca por atributos na tabela em uso \\
\hline$\checkmark ?$ & Construir consulta & $\begin{array}{c}\text { Permite montar uma equação para seleção através de um } \\
\text { ou mais atributos na tabela em uso }\end{array}$ \\
\hline 橎贯 & Juntar & $\begin{array}{c}\text { Une duas tabelas de atributos que apresentam uma } \\
\text { relação espacial }\end{array}$ \\
\hline A & Selecionar & Seleciona as linhas da tabela em uso \\
\hline
\end{tabular}




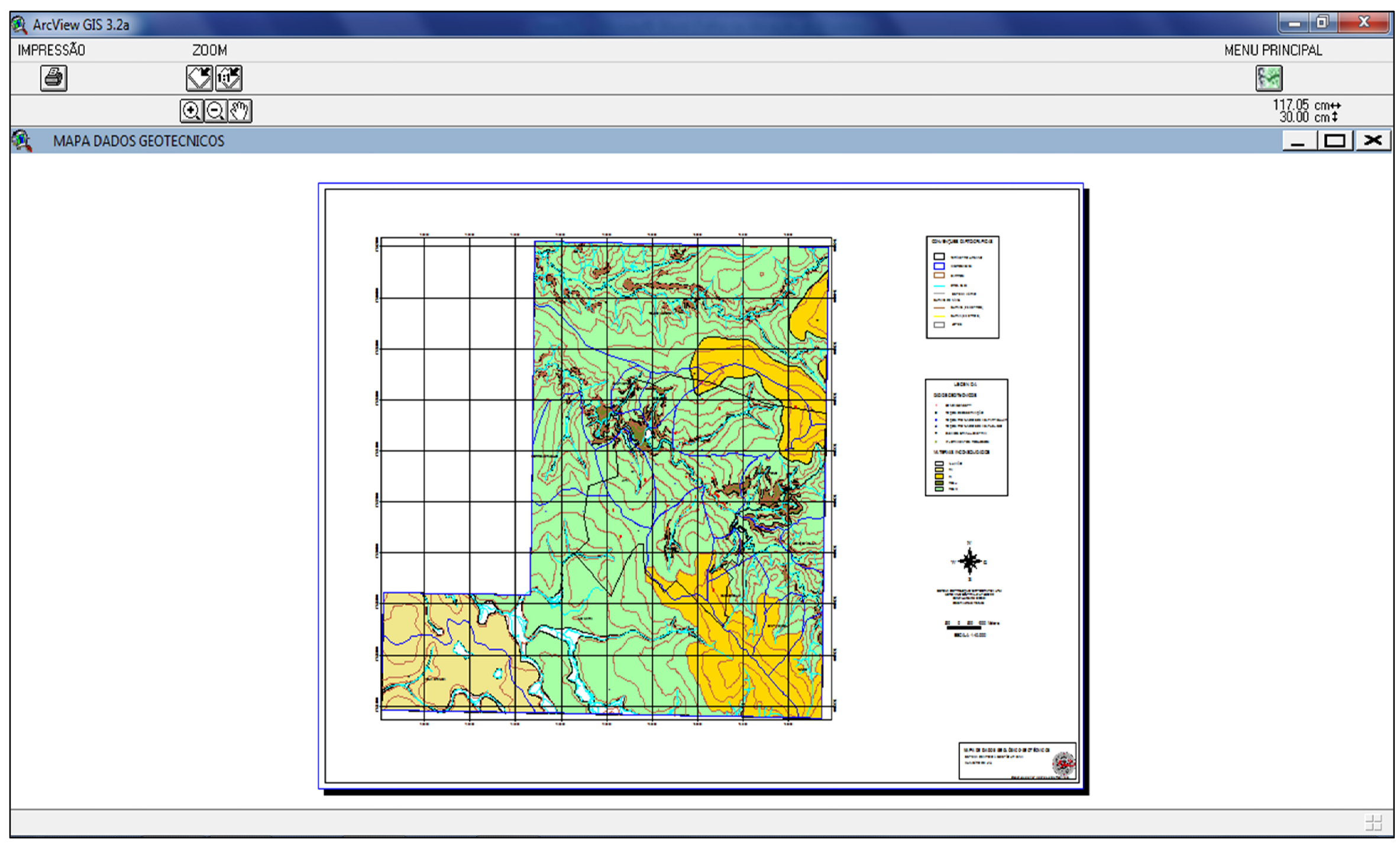

Figura 6.33: Exemplo da tela de visualização do layout em formato A1 - Módulo 2: Dados Geotécnicos. 
Tabela 6.16: Tabela de ícones presentes na tela de layout

\begin{tabular}{ccl}
\hline Imprimir & \multicolumn{1}{c}{ Descrição } \\
\hline Zoom total & $\begin{array}{l}\text { Apresenta o layout em uso em sua } \\
\text { totalidade }\end{array}$ \\
\hline Dumentar Zoom & $\begin{array}{l}\text { Apresenta o layout na escala real de } \\
\text { impressão }\end{array}$ & $\begin{array}{l}\text { Aumenta a escala de visualização } \\
\text { limitando-a a retângulo desenhado com o } \\
\text { auxilio do cursor }\end{array}$ \\
\hline Diminuir Zoom & $\begin{array}{l}\text { Diminui a escala de visualização } \\
\text { posicionando o cursor e clicando-se o } \\
\text { mouse }\end{array}$ \\
\hline Desloca a visualização no sentido em que \\
se deslocar o cursor
\end{tabular}

\subsection{Uso do sistema na gestão urbana}

As atividades desenvolvidas na Secretaria de Planejamento e Obras tratam de emissão de certidões, elaboração de projetos públicos, manutenção da infraestrutura urbana e aprovação de projetos civis. Com base nestas atividades pode ser realizada a validação deste sistema.

Nos itens seguintes são apresentados alguns exemplos da utilização do sistema de apoio a gestão urbana no município de Jaú.

\subsubsection{Projetos Públicos}

As consultas para localização de áreas ideais para instalação de equipamentos públicos são realizadas com frequência na Secretaria de Obras.

As verbas para construção dos equipamentos públicos são repassadas ao município e cabe aos gestores indicar as melhores áreas públicas para a 
construção do novo equipamento. A seguir será mostrado um exemplo de busca onde o Sistema de Gestão Urbana foi utilizado para agilizar tal escolha.

A Secretaria de Saúde reivindicou um local para construção de uma Unidade Básica de Saúde (UBS) no bairro Jardim Orlando Ometto I que tenha $1.000,00 \mathrm{~m}^{2}$.

Utilizando o Sistema de Apoio a Gestão Urbana, o primeiro passo é construir uma equação na função " construir consulta" no Módulo 2 (Dados Geotécnicos) com o tema lotes ativo.

A Figura 6.34 mostra a caixa de diálogo da função utilizada e a equação formulada para identificar os lotes que se encaixem na pesquisa.

De acordo com a equação formulada foram selecionados todos os lotes de propriedade da Prefeitura, que no banco de dados esta relacionado ao número 1 , que estão localizadas no bairro Jardim Orlando Chesini Ometto I, tenham classe de declividade menor ou igual a 2 (até $15 \%$ ), com área de lote maior que $1.000,00 \mathrm{~m}^{2} \mathrm{e}$ área edificada igual a zero. Após a inserção da equação é selecionado o botão new set, que tem a função de executar a pesquisa e mostrá-la na tela.

Para se visualizar com maior facilidade o resultado da pesquisa é utilizado o ícone "Zoom da Seleção", que irá posicionar na tela os lotes selecionado como mostra a Figura 6.35.

$\mathrm{Na}$ elaboração do projeto foi necessário também verificar se haviam furos de sondagem nas imediações do lote utilizado para a construção da UBS, para que os técnicos pudessem ter parâmetros do solo para estimativa do tipo de fundação a ser utilizada no projeto.

A função "Selecionar no Mapa" foi executada no Módulo 2, para localizar furos de sondagem nos lotes selecionados, na caixa da função foi selecionado completely contain (Contido completamente) e o tema sondagens. A Figura 6.36 ilustra o resultado da seleção. 


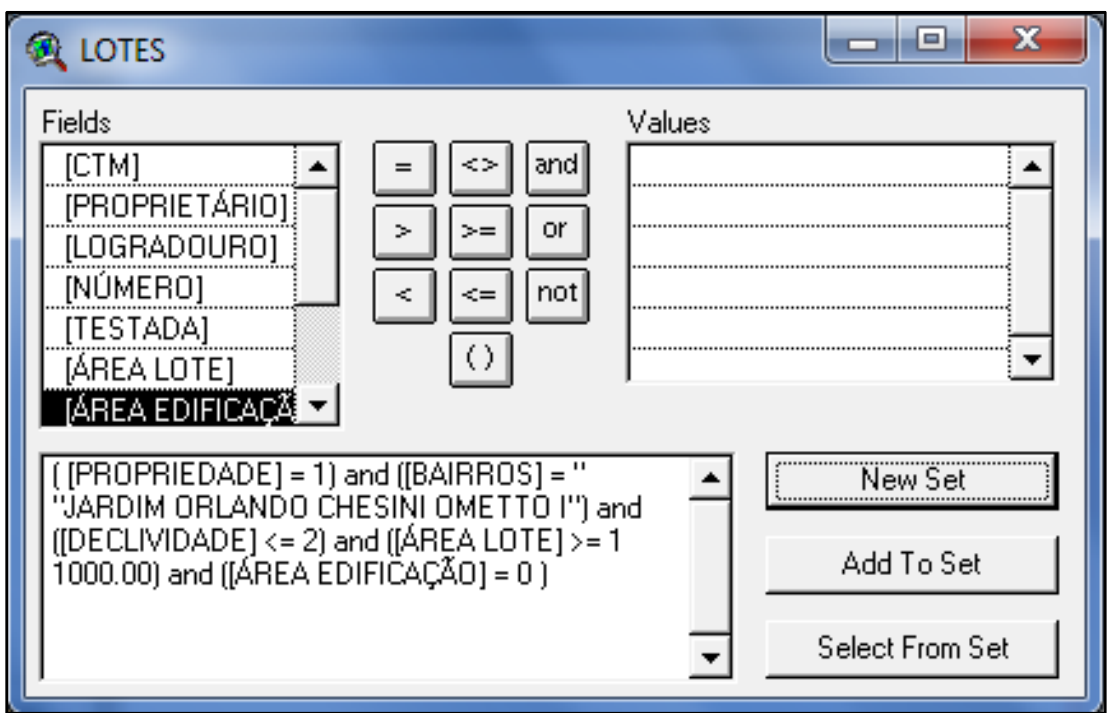

Figura 6.34: Equação utilizada para construir a consulta

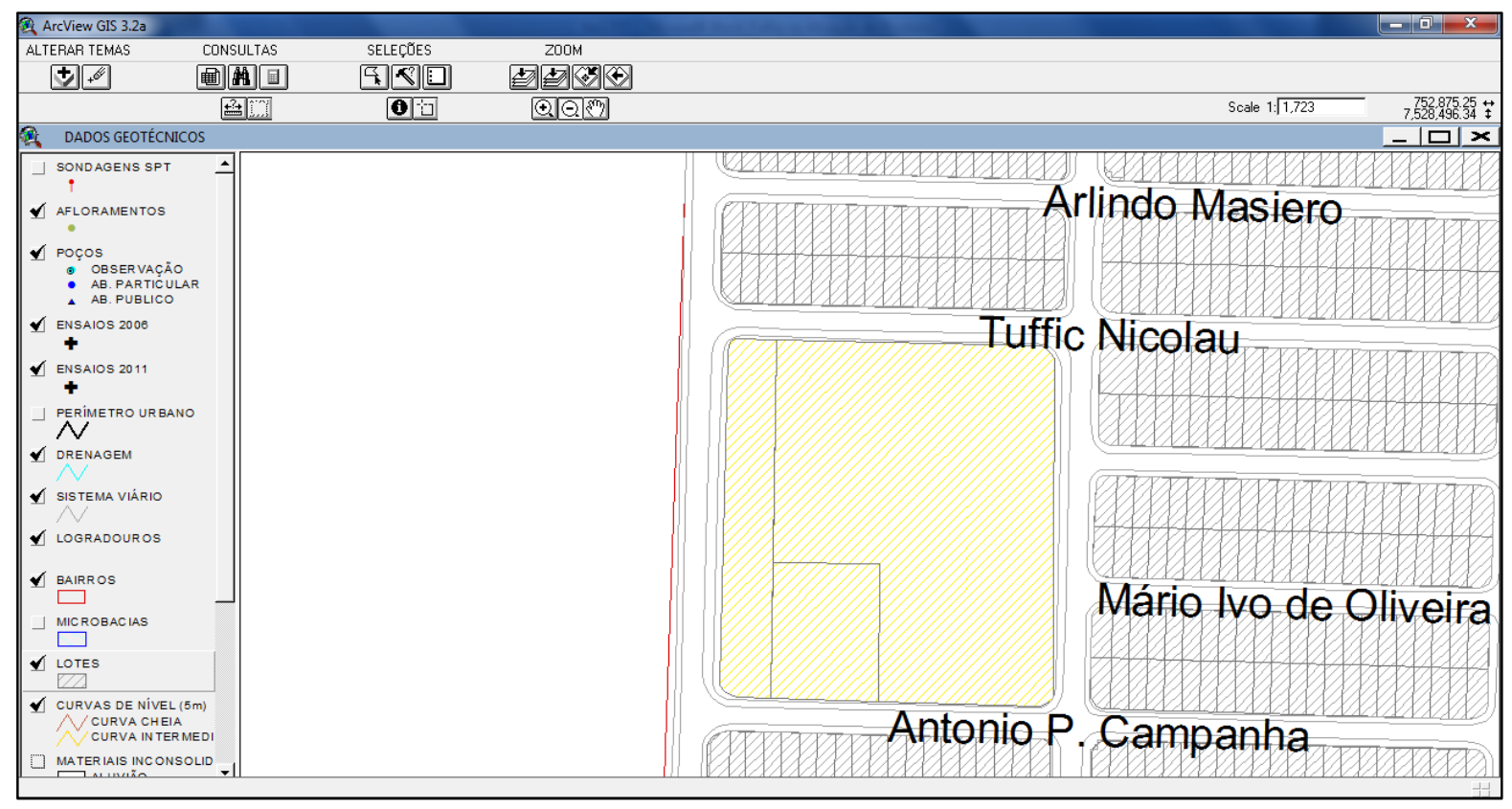

Figura 6.35: Áreas resultantes da consulta no Módulo 2 


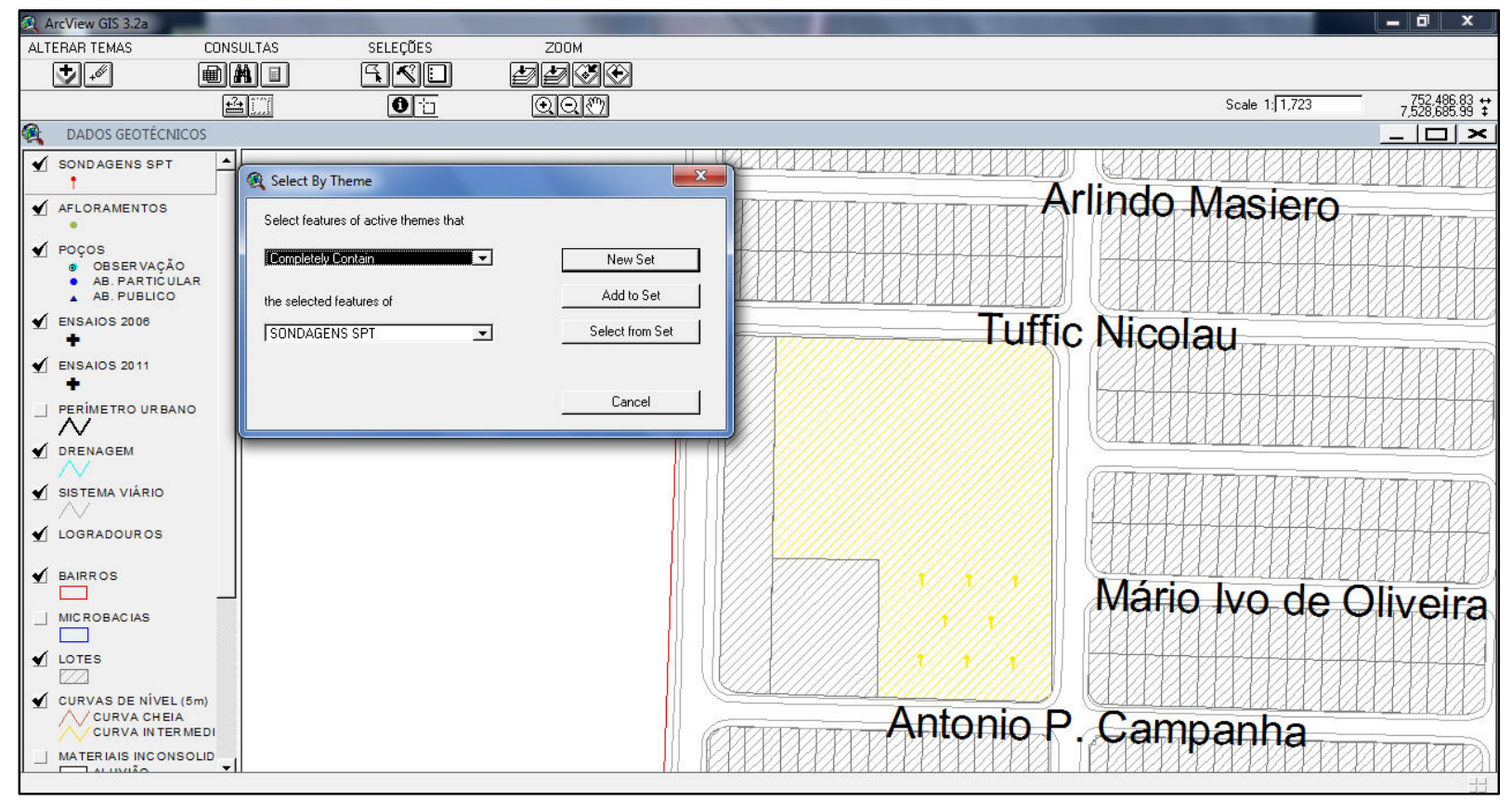

Figura 6.36: Área resultante da seleção de Sondagens SPT

6.3.2 Certidão de uso de solo, aprovação de projetos e alvarás de funcionamento

Para a emissão de certidões de uso de solo, aprovação de projetos civis e os alvarás de funcionamento, deve-se conhecer a zona em que esta inserida a propriedade ou lote consultado. $\mathrm{O}$ zoneamento traz as restrições de uso para cada zona, conhecendo-se a zona pode-se determinar os parâmetros construtivos e o usos compatíveis.

No Sistema de Gestão Urbana a pesquisa foi realizada através do Cadastro Territorial Municipal (CTM), para isto utiliza-se o Módulo 1 (Uso do Solo) com o tema lote ativo e a função "buscar". O CTM é um número único para cada lote, portanto, não existem dois números iguais dentro da base de dados.

A Figura 6.37 ilustra a busca por CTM para avaliar em qual zona se encontra o lote. 


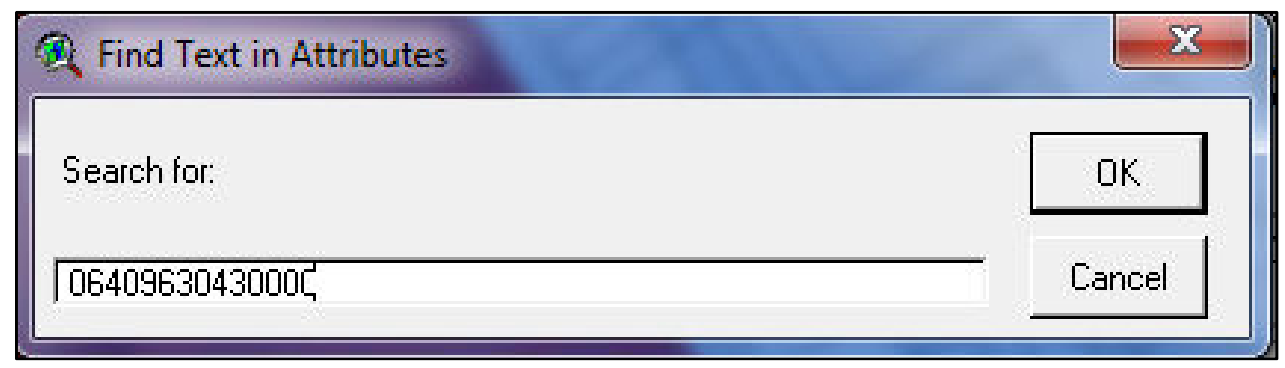

Figura 6.37: Função buscar utilizando CTM

Após a inserção do número do CTM o lote a que o número se refere é selecionado na tela, para melhor visualizá-lo utilizou-se a função "Zoom da Seleção", assim o lote fica posicionado na tela com a cor amarela (seleção).

Abrindo a tabela de atributos pela função "abrir tabela" e em seguida usando a função "promover", a linha que contém as informações referentes ao CTM fica no topo da tabela.

A Zona em que o lote esta inserido pode ser localizada tanto visualmente pelo mapa em tela, quanto pela tabela de atributos na coluna Zona. No caso em questão a zona é ZEC-PH representada no mapa pela cor branca. A Figura 6.38 apresenta o resultado da busca por CTM, visualizada na tela e na tabela de atributos

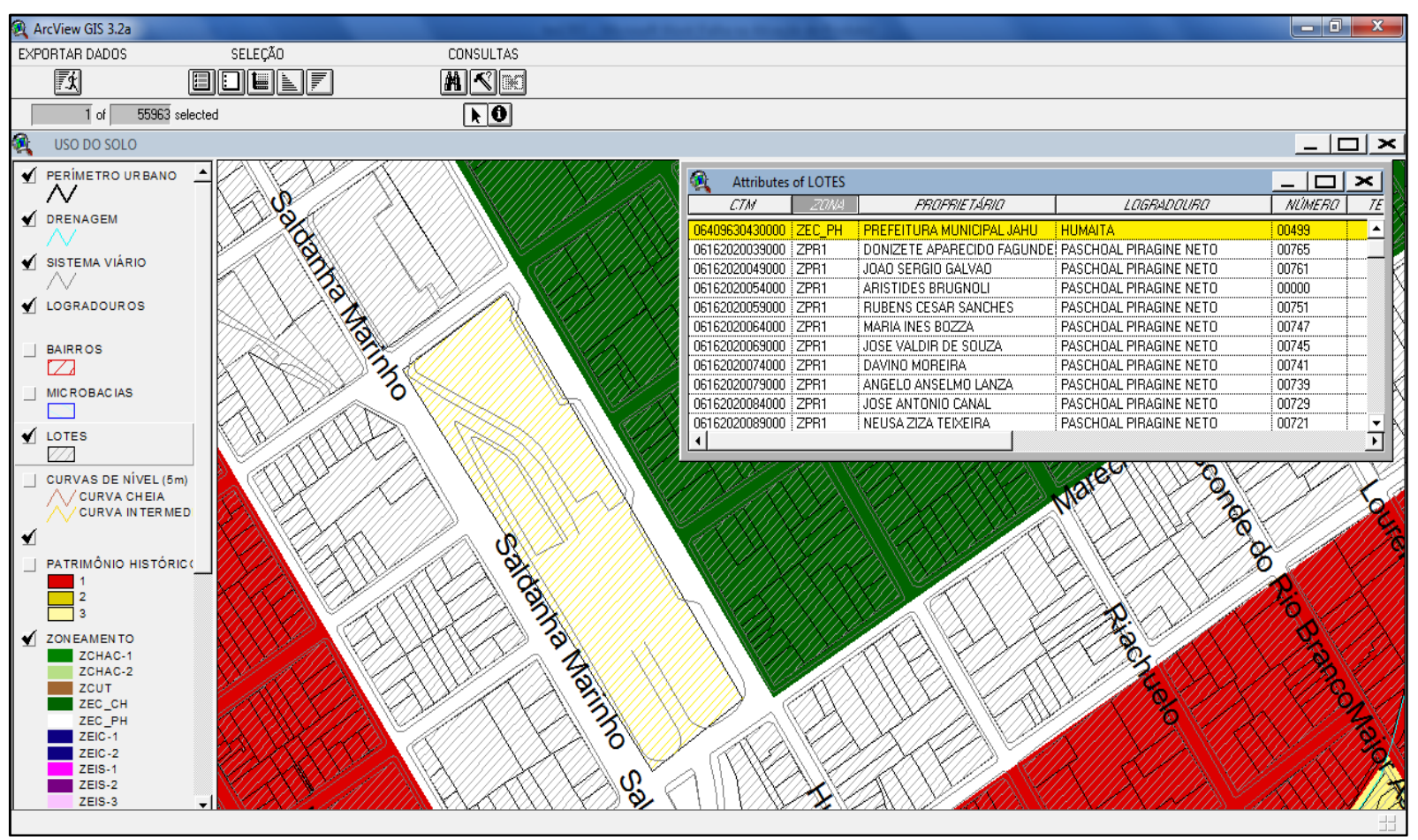

Figura 6.38: Visualização do resultado da busca na tela e na tabela de atributos 


\subsubsection{Certidão de Diretrizes para loteamentos}

A primeira etapa na aprovação de um loteamento ou condomínio é a emissão da Certidão de Diretrizes, que fornece ao empreendedor informações sobre os parâmetros e deveres que ele deverá cumprir.

A Certidão de Diretrizes deve conter: zoneamento da área, declividade, tipo de solo, possíveis áreas de riscos, localização e dimensões da rede de água e esgoto e áreas de preservação ambiental.

Para utilização do Sistema de Gestão Urbana na emissão de Certidão de Diretrizes foi necessário solicitar ao empreendedor um arquivo digital com o croqui da gleba onde se pretendia instalar o loteamento.

A primeira etapa é inserir o arquivo da gleba nos módulos que serão utilizados para avaliação dos parâmetros necessários. Para adicionar este novo tema foi utilizada a função "inserir tema", inserindo o arquivo em formato $d x f$ (Figura 6.39)

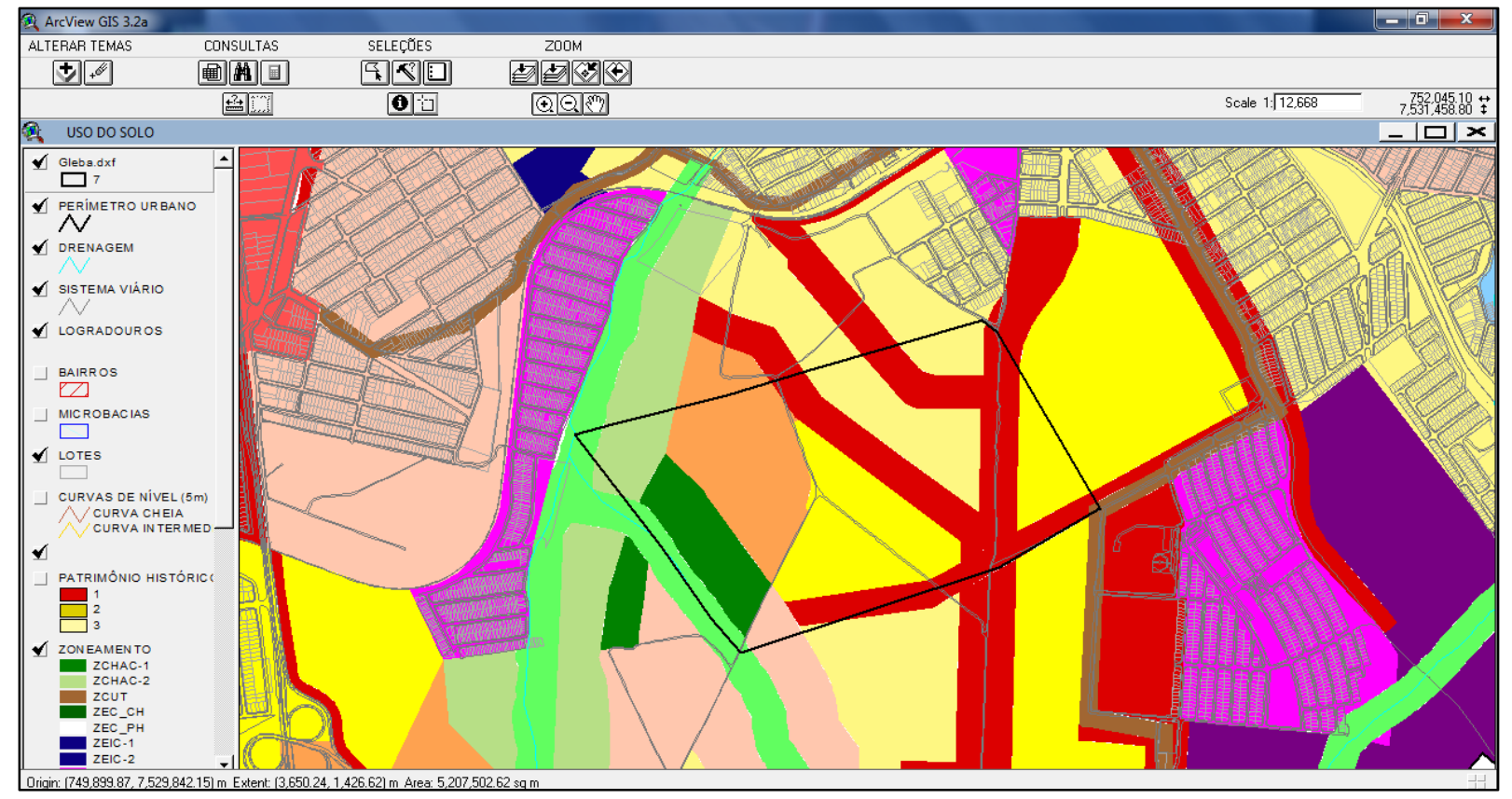

Figura 6.39: Visualização da gleba adicionada no Módulo 1 - Uso do Solo 
Verificou-se que a gleba esta inserida em varias zonas, são elas: Zona Exclusivamente Residencial 1 (ZER1), Zona Exclusivamente Residencial 2 (ZER 2), Zona Predominantemente Residencial 1 (ZPR1), Zona Predominantemente Residencial 2 (ZPR2), Zona de Serviço e Comércio (ZSECOM) e Zona de Chácara 1 (ZCHAC 1).

No módulo 2 (Dados Geotécnicos) verificou-se os tipos de solos presentes na área a ser loteada, a Figura 6.40 ilustra a gleba inserida no Módulo 2, podendo-se visualizar o mapa de materiais inconsolidados.

Pôde-se avaliar que a área do loteamento apresenta o Solo Residual da Formação Serra Geral Maduro (RSGM) e uma pequena parcela do Solo de Aluvião próximo ao talvegue do Córrego da Figueira, inserido na área de preservação permanente. Outro dado a ser observado é a falta de pontos de poços de abastecimento público no entorno da gleba.

A infraestrutura urbana foi avaliada no Módulo 3 (Infraestrutura Urbana) verificando-se se há redes de água e esgoto disponíveis (Figura 6.41). Conclui-se que não há rede de distribuição de água ou rede de coleta de esgoto sanitário próximo a área.

No Módulo 4 (Relevo) verificou-se as classes de declividade presentes na gleba. Observando a Figura 6.42 conclui-se que as declividades predominantes estão entre 0 e $15 \%$, sendo a maior parte da área entre 0 a $6 \%$.

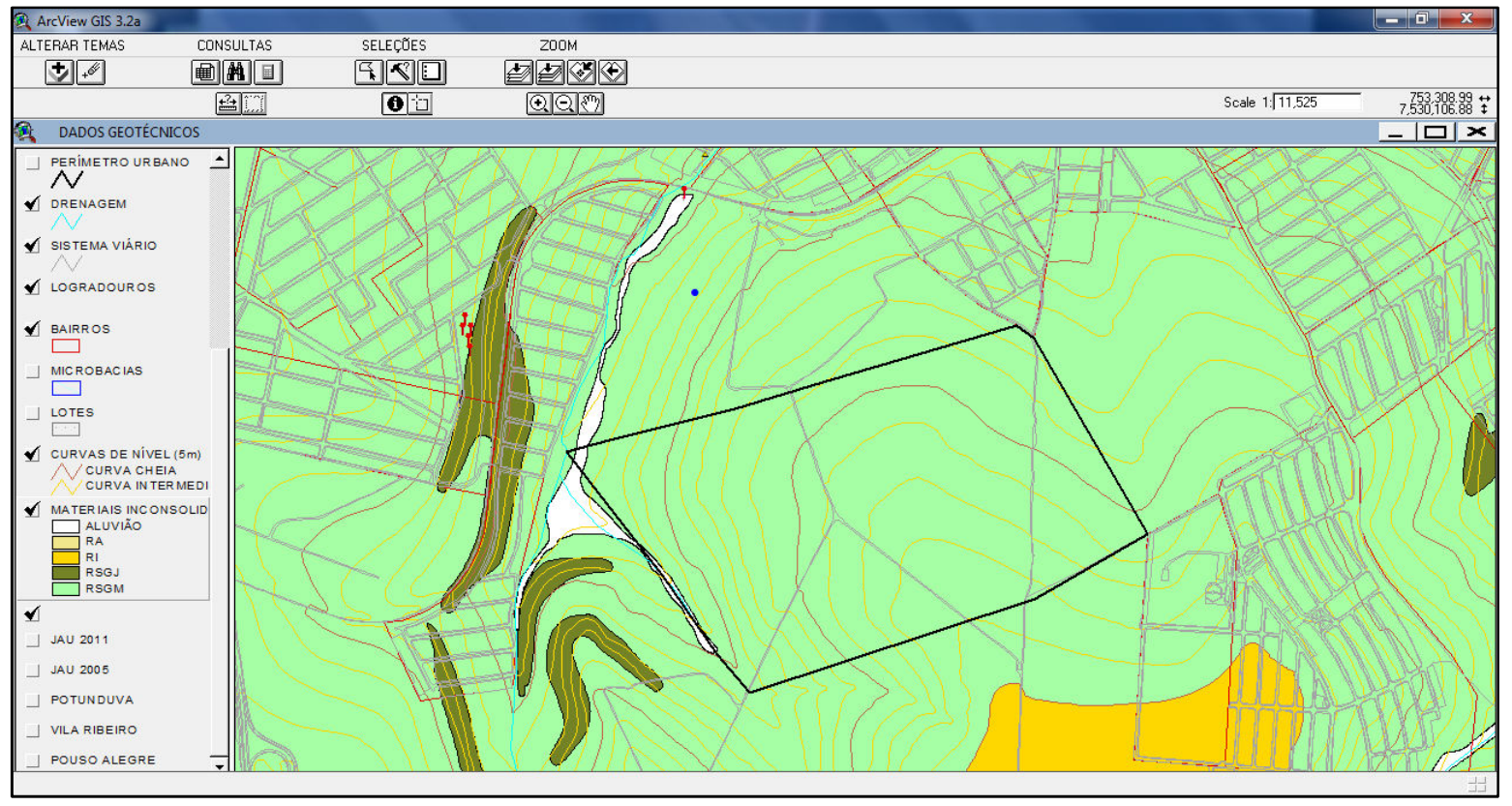

Figura 6.40: Visualização da gleba adicionada no Módulo 2 - Dados Geotécnicos 


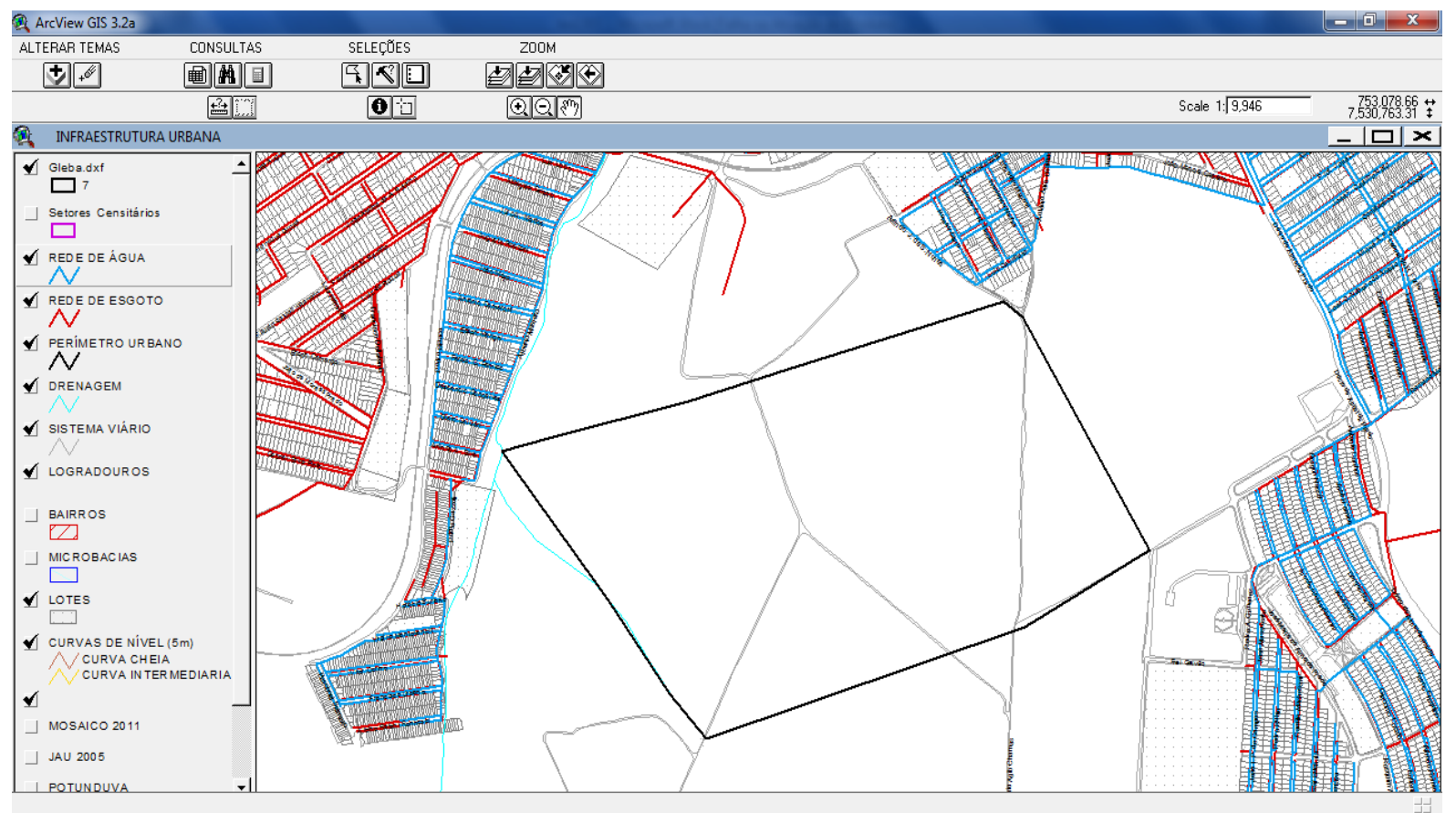

Figura 6.41: Visualização da gleba adicionada no Módulo 3 - Infraestrutura Urbana

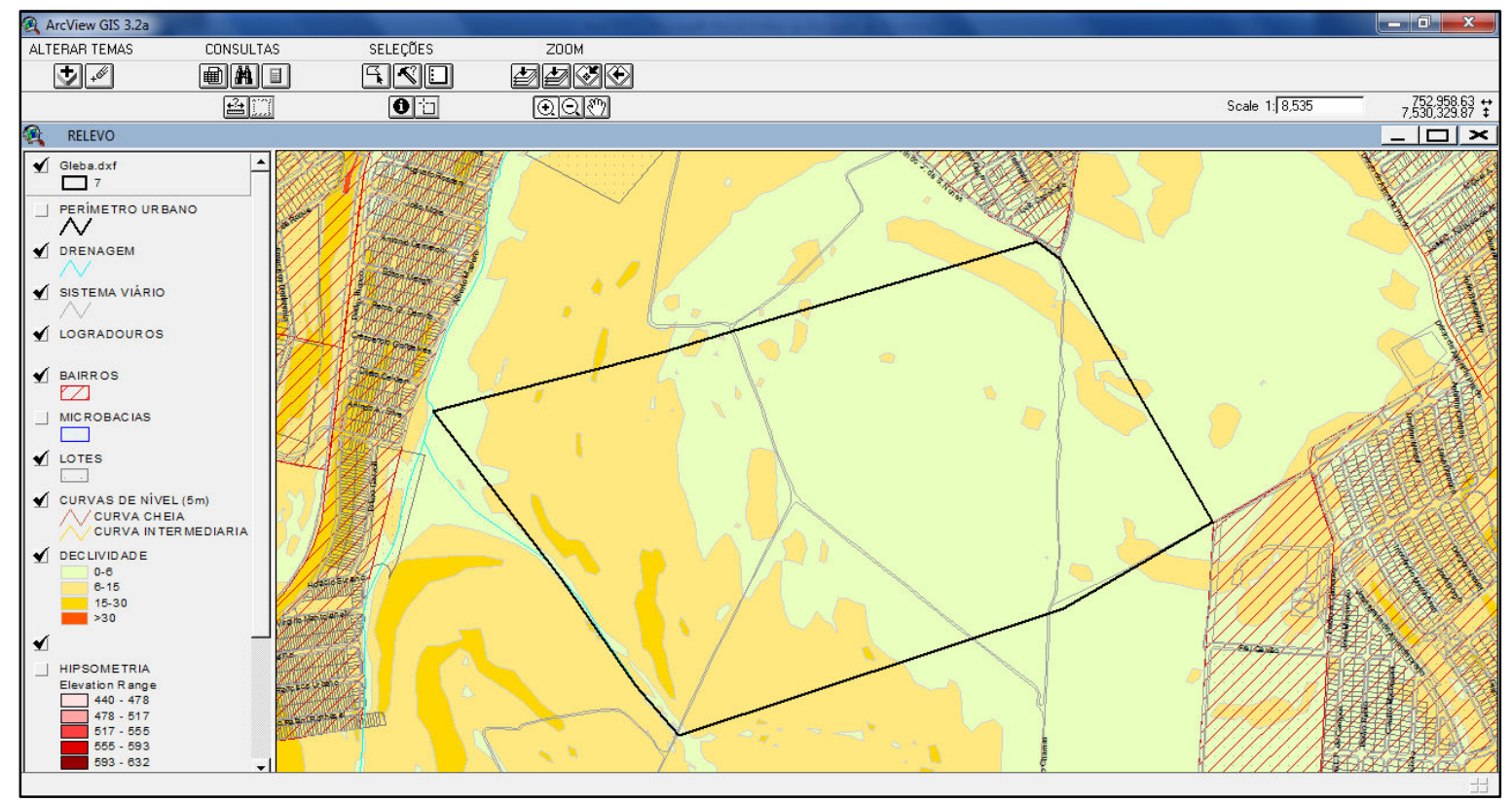

Figura 6.42: Visualização da gleba adicionada no Módulo 4 - Relevo

A orientação quanto as restrições ambientais foram avaliadas no Módulo 5 (Preservação Ambiental), parte da área do loteamento está inserida na ZEPUR do Parque da Figueira (Figur6a 6.43). Através da função "Calcular Área" 
verificou-se que a área ocupada pelo parque dentro da Gleba é de 24.349,17 $\mathrm{m}^{2}$ perfazendo cerca de $2 \%$ da área total (Figura 6.44).

$\mathrm{Na}$ análise do Módulo 6 (Áreas de Risco) verificou-se a ausência de processos erosivos e inundações cadastradas nesta área, conforme ilustra a Figura 6.45 .

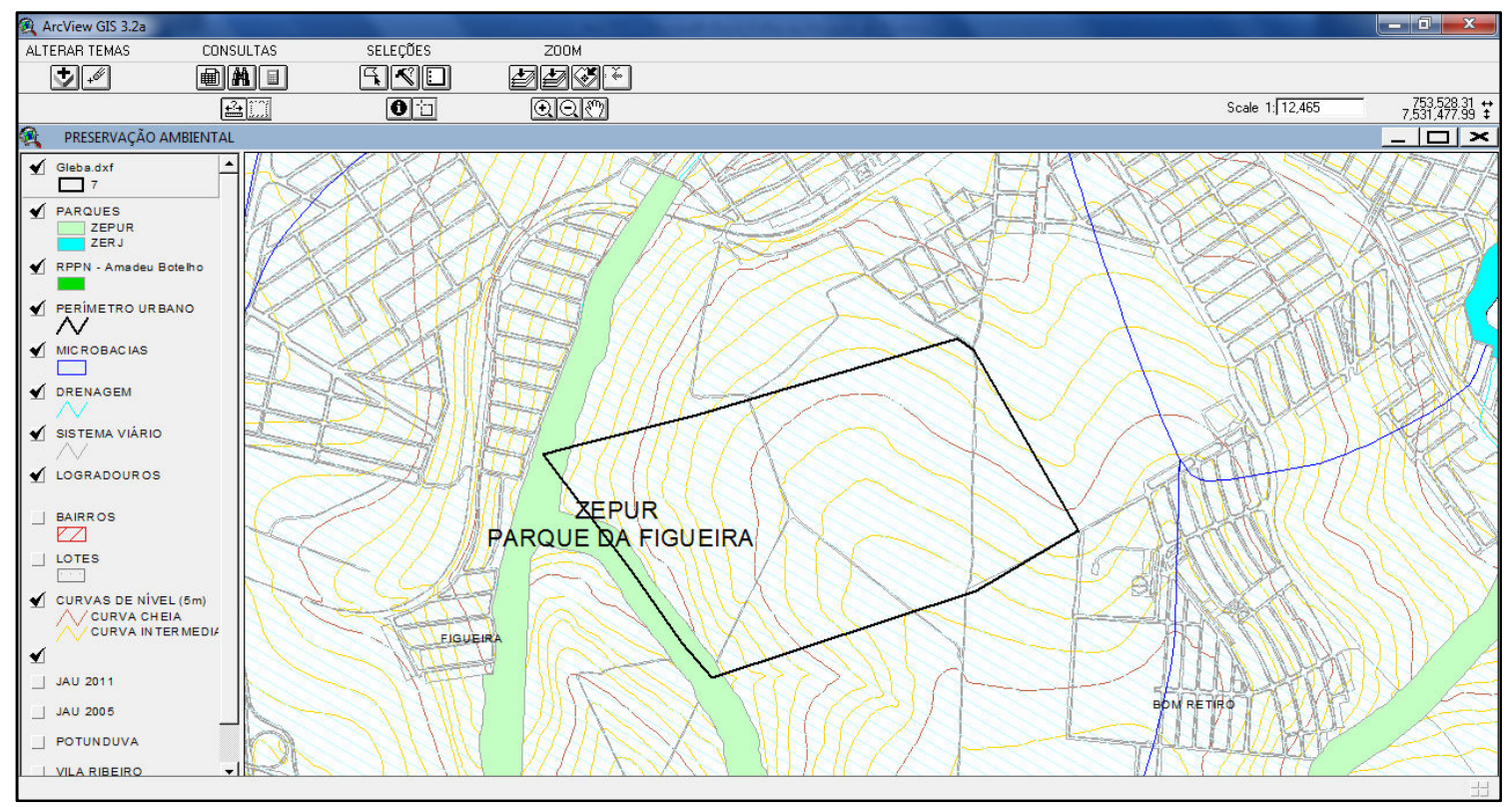

Figura 6.43: Visualização da gleba adicionada no Módulo 5 - Preservação Ambiental

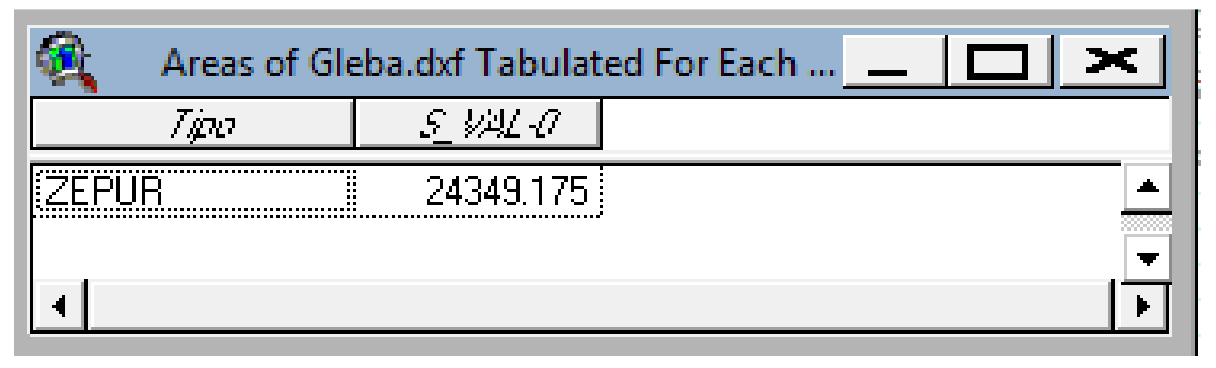

Figura 6.44: Utilização da função "Calcular Áreas" 


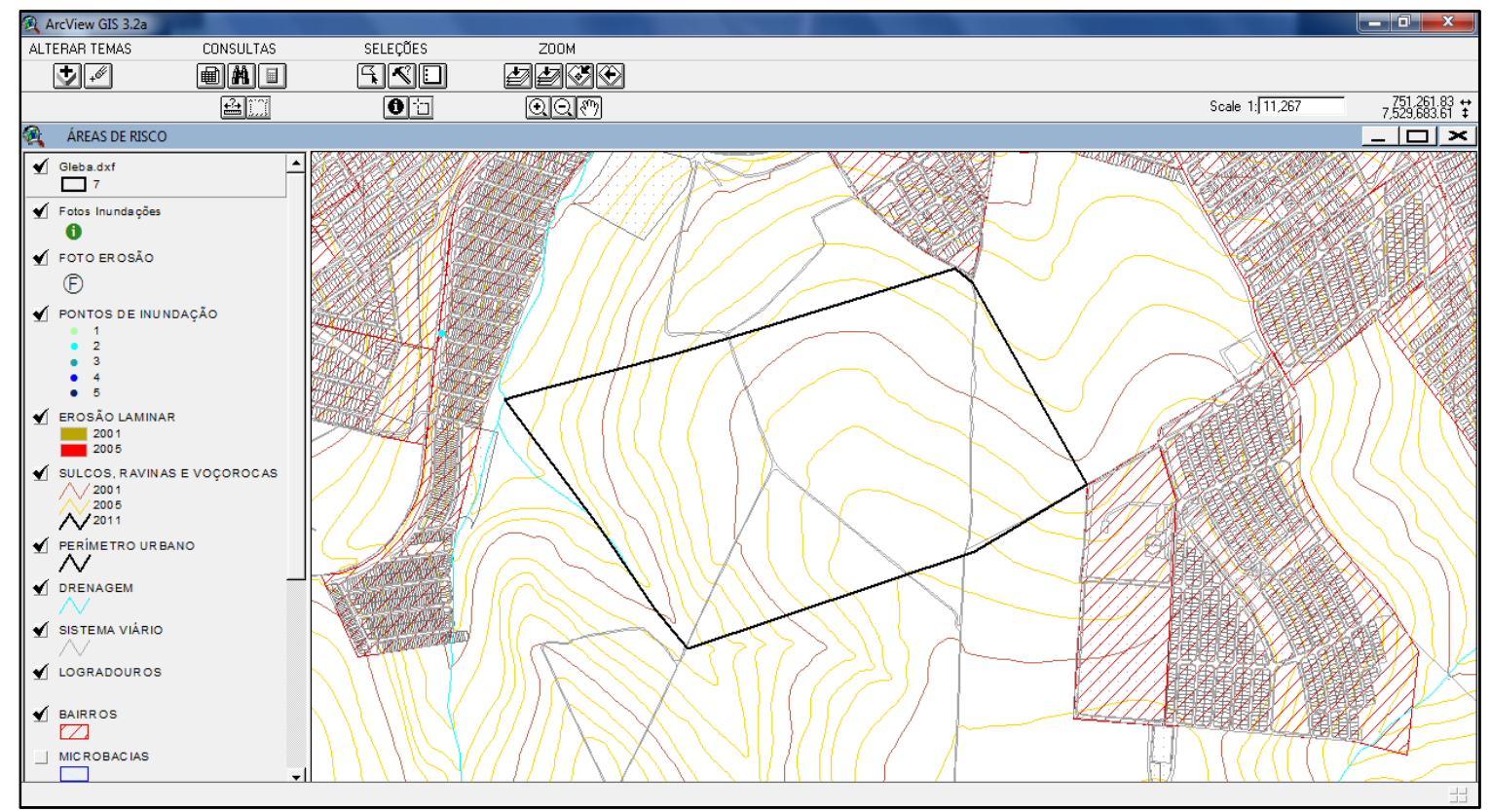

Figura 6.45: Visualização da gleba adicionada no Módulo 6 - Áreas de Risco

Analisando-se todos os módulos pode-se emitir a Certidão de Diretrizes baseada nas informações consultadas no Sistema de apoio à Gestão Urbana, informando que:

- A área apresenta seis tipos de zonas diferentes: ZER1, ZER2, ZPR1, ZPR2, ZSECom e ZCHAC1. Para cada zona existem restrições específicas que devem ser respeitadas no parcelamento e uso do solo (Quadro do Anexo A);

- Os solos encontrados na área são o RSGM e Aluvião, este último próximo ao Córrego da Figueira em área de Preservação (ZEPUR), portanto não será ocupado;

- A maior parte da área possui declividade suave $(<6 \% \%)$, no restante da área são encontradas declividades de 6-30\%, com maior incidência até $15 \%$, nestes locais a ocupação deve ser feita com acompanhamento técnico, projeto de terraplanagem e condução de águas pluviais;

- No local não há rede de água que deverá ser conduzida a partir do Bairro Chácara Nunes, em vista da possibilidade de adução por gravidade;

- O local não apresenta processos erosivos ou locais com risco a inundações. 


\section{ANÁLISES DOS RESULTADOS}

O objetivo principal deste trabalho foi elaborar um sistema de apoio à gestão urbana. Para se alcançar este resultado, realizou-se a customização do sistema em um programa de SIG (Arcview 3.2a) e foi estruturada uma base integrada de dados espaciais necessária para o sistema poder desenvolver sua função.

A base de dados deste trabalho foi formada por informações de natureza geológico-geotécnica, da infraestrutura e do planejamento urbano e as relativas à legislação e às restrições ambientais. Estas informações foram estruturadas em um banco de dados geográficos que serviu de suporte para a implantação do sistema de apoio à gestão urbana.

\subsection{Base de dados}

A integração e a complementação da base de dados foram essenciais para o funcionamento do sistema. A Prefeitura já contava com alguns dados 
cadastrais, havia outras informações e dados dispersos em diferentes formas e meios de acesso.

A agregação dos dados de caráter geológico-geotécnicos também foi fundamental na gestão urbana, pois eles fornecem informações do território municipal que são imprescindíveis para o desenvolvimento planejado e sustentado.

A base cartográfica foi elaborada para servir a todos os módulos temáticos do sistema, pois os elementos que a compõem são necessários para as consultas e análises em todos eles. Dessa forma, em qualquer um dos módulos do sistema podem ser visualizados os oito temas que formam a base de cartográfica.

Os mapas de unidades geológicas e de materiais inconsolidados foram produzidos a partir de mapas de escalas regionais, e seus contatos foram verificados em campo, com apoio em ensaios de laboratório de granulometria. Há a necessidade de se detalhar, ainda mais, as unidades, com novos ensaios e trabalhos de campo e isto poderá ser executado pela prefeitura a fim de se refinar o mapeamento da área. Contudo para a finalidade de planejamento e gestão urbana, estes mapas foram eficazes durante os testes.

O mapa de declividade refletiu bem as características do relevo da área estudada e a divisão das classes de declividade foi importante na análise e no planejamento de novos empreendimentos urbanos.

No mapa de áreas de risco, os locais com problemas de erosão e inundações foram cadastrados, utilizando os registros em jornal e da defesa civil, fotografias aéreas e verificação em campo. Para a continuidade deste trabalho, o município poderá investir em uma estrutura mínima para atualização e cadastro continuados destas áreas de risco (imagens aéreas atualizadas, rotina de cadastro e atualização, maior integração com os técnicos da defesa civil municipal e estadual, etc.).

Os dados geotécnicos forneceram informações relevantes para a definição de tipos de fundação (prédios públicos), locais com topo rochoso raso, visualização da rede de poços de captação de água subterrânea, entre outros. Com a inserção de novos dados poderão ser executadas interpolações do lençol freático, da profundidade do maciço rochoso e de outras análises espaciais pertinentes para as ações de gestão urbana e territorial. 


\subsection{Sistema e aplicações}

A definição da interface e dos módulos que compuseram o sistema foi elaborada de acordo com os objetivos, a tipologia e a quantidade das informações, os tipos de consultas e tendo o técnico municipal como usuário principal. $\mathrm{O}$ programa de SIG utilizado também condicionou a estruturação e a formatação do sistema, que poderiam ser diferentes em outro município e com a utilização de outro programa. O programa Arcview 3.2a foi escolhido por ser de fácil acesso e por possuir as principais ferramentas de análise espacial de um SIG.

Os seis módulos propostos visam facilitar as consultas e as análises espaciais por área de informação utilizada normalmente nos procedimentos de rotina dos técnicos municipais.

As consultas realizadas na Secretaria de obras, que foram descritas no item 6.3, permearam vários módulos, portanto para cada tipo de rotina realizada na prefeitura será utilizado um modulo específico ou mais. No caso da expedição de Certidão de Diretrizes para loteamento todos os módulos foram consultados.

Antes do sistema, esta pesquisa era realizada em mapas impressos, quando disponíveis. Quando os técnicos municipais não detinham as informações, elas eram omitidas da certidão. A pesquisa em mapas impressos, além de ser demorada, gerava interpretações confusas, principalmente no mapa de zoneamento. As zonas acabavam sendo definidas com muita imprecisão.

A impressão das consultas ou dos mapas pode ser utilizada como documentos para obras de convênios, ou pelos gestores municipais para trabalhos técnicos de campo.

O uso do sistema acrescentou maior agilidade e precisão às consultas e às análises, isto trouxe maior confiança para os gestores técnicos na elaboração de projetos de construções e no planejamento da cidade. 


\section{CONCLUSÕES}

O conhecimento da área de estudo é essencial para o desenvolvimento de ações voltadas ao planejamento territorial e à gestão urbana, não apenas o conhecimento do ambiente, e sim a organização das atividades, as ações realizadas pela prefeitura e a disponibilidade de recursos financeiros.

A integração de dados geológico-geotécnicos, da infraestrutura e do planejamento urbano e das restrições ambientais em um único banco de dados possibilita maior entendimento dos fenômenos relativos à urbanização, alçando melhores resultados nas definições relacionadas à gestão urbana.

A implantação de um sistema de apoio a gestão urbana municipal é um importante instrumento tecnológico para análise espacial. Neste trabalho, o sistema desenvolvido e aplicado no município de Jaú (SP), utilizando uma plataforma em SIG e com interface específica em seis módulos de consulta e análise, possibilitou uma conexão entre os dados descritivos e as informações gráficas que os técnicos municipais dispunham, além de agregar novas informações de natureza geológicogeotécnica produzidas pela pesquisa, permitindo análises espaciais que tornaram o processo de gestão urbana mais ágil e fundamentado. 
As informações de natureza geotécnica foram fundamentais para definições de áreas e de tipologias de fundações de obras públicas. Tais dados também podem ser explorados para definições de topo rochoso, níveis de água e interpolações por camadas de solo.

A atualização da base de dados deverá ser realizada para que o sistema mantenha sua funcionalidade. Destaca-se a constante agregação de dados de sondagens e de outras investigações geológico-geotécnicas que a prefeitura tenha acesso, além da execução levantamentos específicos voltados à complementação e detalhamento dos mapas e demais dados e informações desta base de dados do sistema de gestão urbana e territorial. 


\section{REFERÊNCIAS BIBLIOGRÁFICAS}

AIBINU, A. GIS application in urban planning and urban management: utilising GIS in Kigali urban planning and city management. In CORP - International Planning \& Geo-Multimedia. Italia. 2001.

ALMEIDA C., CÂMARA G., MONTEIRO A. M. Geoinformação em Urbanismo: Cidade Real x Cidade Virtual. São Paulo: Oficina de Textos, 2007. 366 p.

ALVES, W. P. Fundamentos de banco de dados. São Paulo: Editora Érica, 2004, $382 \mathrm{p}$.

ANGELINI, G.; MAZZACANE, D.; SELICATO, F.; TORRE, C. M. Construction of GIS Application for Methods of Spatial Evaluation in Environmental Planning. In: DESIGN \& DECISION SUPPORT SYSTEMS IN URBAN PLANNING. Proceedings of the $5^{\text {th }}$ International Conference. Nijkerk, The Netherlands, 2000, p. 1-18.

ARAUJO, G. H. S.; ALMEIDA, J. R.; GUERRA, A. J. T. Gestão Ambiental de Áreas Degradadas. Editora Bertrand Brasil. $3^{\mathrm{a}}$ ed. Rio de Janeiro/RJ, 2008, 320p.

AUGUSTO FILHO, O.; AKIOSSI, A.; KERTZMAN, F. F. Utilização do SIG no gerenciamento de passivo ambiental: um exemplo para empreendimento 
rodoviário. In: Congresso Brasileiro de Geologia de Engenharia e Ambiental, X, Ouro Preto/MG, 2002, Anais em CDROOM. ABGE. 10p.

AUGUSTO FILHO, O. Implementação de banco de dados geotécnicos como ferramenta adicional nas ações de gestão urbana da URBEL. Relatório Técnico, $2005,14 p$.

BASTOS, G. (2005). Banco de dados em mapeamento geotécnico aplicado à região de Ribeirão Preto (SP). Tese de doutorado. Departamento de Geotecnia/ Escola de Engenharia de São Carlos - EESC/USP. São Carlos-SP. 306 p.

BRAGA, R. Perspectivas de Gestão Ambiental em Cidades Médias. Rio Claro: LPM -UNESP, 2001. pp. 95 -109.

BRASIL. Lei $N^{\circ}$. 6.766, de 19 de dezembro de 1979. Dispõe sobre o parcelamento do solo urbano e dá outras providências. Brasília - DF. 1979. Disponível:http://www6.senado.gov.br/legislacao/ListaPublicacoes.action?id=125757, Acesso em: 13/11/2007.

BRASIL Decreto n. ${ }^{01.922}$, de 5 junho de 1996. Legislação das Reservas Particulares - Projeto IBAMA/RPPN. 1996. Brasília-DF. Disponível em: http://www.ibama.gov.br/siucweb/ guiadechefe/guia/lei.doc, acesso em 27/02/2007.

BUNDY, G. L. I., Jones, C. B., Furse, E. Holistic Generalization of Large-Scale Cartographic Data. In Müller, J. C., Lagrange, J. P., Weibel, R. (editors) GIS and Generalization: Methodology and Practice, Taylor \& Francis, London, 1995.

BURIAN, J. GIS analytical tools for planning and management of urban process. In 15 Year of Interntional Symposium GIS. Ostrava-Republica Tcheca. 2008.

CÂMARA, K. R. R., PEREIRA, A. C. Análise de perfis de sondagem SPT e caracterização geotécnica de solos no município de Natal. Revista Holos. V. 1 Natal-RN. 2005

CÂMARA, G.; MONTEIRO, A. M.; SPOSATI, A.; RAMOS, F. R.; KOGA, D.; AGUIAR, A. P. D. Territórios digitais: as novas fronteiras do Brasil. Seminários temáticos para a $3^{a}$ Conferência Nacional de C,T\&I. Inpe. São José dos Campos/SP, 2003.

CÂMARA, G. Análise Espacial de Dados Geográficos, Escola de Verão, IMPA, fevereiro de 1999. Congresso GIS Brasil 1999, Foz do Iguaçu, 1999. 
CASTANHO, V. CDR analisa uso obrigatório de carta geotécnica para elaboração de planos diretores. Agência Senado, 2011, Disponível em: http://www.senado.gov.br/noticias/ cdr-analisa-uso-obrigatorio-de-carta-geotecnicapara-elaboracao-de-planos-diretores.aspx , acesso em: 16/08/2011.

CHADWICK, G. A systems view of planning: towards a theory of the urban and regional planning process. Pergamon Press. Oxford. 1971. $390 \mathrm{p}$.

CHOAY, F. O urbanismo. Editora Perspectiva. 5a ed. São Paulo/SP. 2003.

CINTRÃO, L. M.G; CINTRÃO, L. P. Gestão de cidades com suporte de ferramenta GIS. Apostila de curso. GISBrasil. 19-22 de agosto de 2003. São Paulo/SP, 2003.

COLLAÇO, D. L. Caracterização geológico-geotécnica do município de São Leopoldo para fins de planejamento como subsídio ao Plano Diretor. Dissertação de Mestrado. EESC/USP, São Carlos/SP. 2003.

CYMBALISTA, R. Estatuto da Cidade: guia para implementação para municípios e cidadãos. Instituto Polis, São Paulo/SP, 2001, 273 p.

DEPARTAMENTO DE ÁGUAS E ENERGIA ELÉTRICA DO ESTADO DE SÃO PAULO - DAEE. Mapa Geológico - Folha Bauru. Escala 1:250.000. DAEE. São Paulo/SP. 1982.

DEPARTAMENTO DE ÁGUAS E ENERGIA ELÉTRICA DO ESTADO DE SÃO PAULO - DAEE. Manual de Operação de Poços . DAEE. São Paulo/SP. 1982.

DEPARTAMENTO DE ÁGUAS E ENERGIA ELÉTRICA DO ESTADO DE SÃO PAULO - DAEE. Mapa das Águas Subterrâneas do Estado de São Paulo escala 1:1.000.000 . DAEE. São Paulo/SP. 2005.

DAVIS Jr. C. A. Múltiplas Representações em Bancos de Dados Geográficos. Disponível em:http://homepages.dcc.ufmg.brclodoveu/files/100.40/AC024. \% 201999 \%20Multiplas\%20representacoes $\% 20 \mathrm{em} \% 20$ bancos $\% 20$ de $\% 20$ dados\%20geografic os.pdf. Belo horizonte. 2008.

DAVIS Jr. C. A., Múltiplas representações em Sistemas de Informações Geográficas. Tese de Doutorado. UFMG. Belo Horizonte/MG.2000, 106p. 
DAVIS Jr. C. A. SIG do futuro. In: Revista InfoGEO, Curitiba, 1999, v.2, n.8, p.32-33, jul./ago/1999.

ESRI Using ArcView GIS Redlands: Esri, 1996, 350p.

ESRI - Environmental Systems Research Institute. Getting know Arcview GIS: the geographic information system (GIS) for everyone. 2Sd Ed. United States of America, 1997.

FERNANDES, L. A. Estratigrafia e evolução geológica da parte oriental da Bacia Bauru (Ks, Brasil). Tese (Doutorado em Geociências) - Instituto de Geociências, Universidade de São Paulo, São Paulo, 1998. 216 p.

GALANTE, A. C. \&BRITO, J. L. N. S. Aplicação da tecnologia SIG no planejamento urbano municipal: Um estudo de caso do município de Macaé. In: XXI Congresso Brasileiro de Cartografia. Belo Horizonte/MG. Sociedade Brasileira de Cartografia - Rio de Janeiro/RJ, 2003, v. 1. p. 206.

INSTITUTO GEOGRÁFICO E CARTOGRÁFICO - IGC. Folhas Jaú I, Jaú II, Jaú III, Jaú IV, Ibirapitanga, Potunduva, São Lourenço, Navarros e Vila Ribeiro. 1980. Escala 1:10.00.

IPT - INSTITUTO DE PESQUISAS TECNOLÓGICAS DO ESTADO DE SÃO PAULO. Mapa geológico do Estado de São Paulo; escala 1:500.000. v1 (texto) e v2 (mapa). Governo do estado de São Paulo. Secretaria da Indústria, Comércio, Ciência e Tecnologia ,1981.

IPT - INSTITUTO DE PESQUISAS TECNOLÓGICAS. Diagnóstico da situação atual dos recursos hídricos e estabelecimento de diretrizes técnicas para a elaboração do plano da bacia hidrográfica do Tietê - Jacaré. São Paulo, 2000, (Relatório IPT ${ }^{\circ} 40674 / 00$ )

ISHI, M; ISHIMURA, K; NAKAYAMA, T. Management and application of geotechnical data: The geotechnical data information system of the Tokyo Metropolitan government. In: Environmental Geology and Water Sciences Journal. Published by Springer, 1992, Vol. 19, no. 3, p. 169-178.

JAHU. Lei Completmentar 443 de 14 de novembro de 2012. Revisa a Lei Complementar no. 298 de 2007 e dispõe sobre o zoneamento, o parcelamento, I uso e a ocupação do solo no Município de Jahu e dá outras providências. 2012. 
JAHU. Lei Completmentar 298 de 10 de outrubro de 2007. dispõe sobre o zoneamento, o parcelamento, I uso e a ocupação do solo no Município de Jahu e dá outras providências. 2007.

JAHU. Lei Completmentar 277 de 10 de outrubro de 2006. Dispõe sobre o Plano Diretor de Jahu, o sistema e o processo de parcelamento e gestão do desenvolvimento urbano do Município de Jahu. 2006.

KLOSTERMAN, Richard E. "The What if? Planning Support System." In Planning Support Systems, Richard K. Brail and Richard E. Klosterman, eds. Redlands, CA: Environmental Systems Research Institute, 2001.

KOURGANOFF, W. A face oculta da universidade. Tradução Cláudia Schilling; Fátima Murad. São Paulo : Editora da Universidade Estadual Paulista, 1990.

LEONELLI, G. C. V. Da Gleba ao lote: dinâmica e produção da insustentabilidade ambiental urbana. Dissertação de Mestrado. EESC/USP, São Carlos/SP. 2003.

Martin, D. Geographic information systems: socioeconomic applications. Second Edition, London: Routledge. 1996 210p.

MATHEWSON, C. \& FONT, R. G. Geologic environment: forgotten aspects in the land use planning process. The Geological Society of America U. S. A., engineering geology. Case histories, boulden, 1974, (10) p 23-28.

MENDES, R. M. M. Mapeamento Geotécnico da Área Central Urbana de São José do Rio Preto (SP) na Escala 1:10.000 como Subsídio ao Planejamento Urbano. Dissertação de Mestrado. Programa de Pós - Graduação em Engenharia Urbana / Centro de Ciências Exatas e de Tecnologia / Universidade Federal de São Carlos. 2001. 245p.

MIRANDA, J. G. Mapeamento geotécnico e estudo da suscetibilidade à erosão na bacia do Ribeirao Ponte de Pedra (MT), escala: 1:100.000. Tese de doutorado. Departamento de Geotecnia/ Escola de Engenharia de São Carlos - EESC/USP. São Carlos-SP. 2005.

MOTA, S. Urbanização e Meio Ambiente. Rio de Janeiro, ABES, 1999. 
MOURA, A. C. M. Geoprocessamento na gestão e planejamento urbano. Editora Difusora. Belo Horizonte/MG, 2003, 294 p.

MUNDOGEO, Ministério das Cidades integra bases de dados geográficos na internet. Artigo de revista on line: MUNDOGEO, 2008, disponível em: http://www2.cidades.gov.br/geosnic/src/php/app.php. Acesso em 19/05/2008.

NEVES, N. A. G. S. GEOMETA - Elementos mínimos geográficos para análise territorial e ambiental. Departamento de planejamento biofísico e paisagístico. Universidade de Évora.Portugal, 2000, Disponível em: www.amde .pt/document /447750/450924 .pdf. Acesso em 11/04/2008.

OLIVEIRA, A. M. S. \& BRITO, S. N. A. Geologia de Engenharia. ABGE. São Paulo/SP, 1998, 587p.

PALANCA, R.T.S. \& KOFFLER, N.F. Avaliação agrícola das terras da bacia do Rio Jaú (SP) através das técnicas de geoprocessamento. Fundação Educacional "Dr. Raul Bauab de Jaú/Sp". Faculdade de Filosofia Ciências e Letras, Jaú/SP, 1996.

PAULA E SILVA F. CHANG H. K. , CAETANO-CHANG, M. R. Perfis de referência do Grupo Bauru (K) no Estado De São Paulo, Revista Geociências, v. 22, N. Especial, São Paulo, UNESP, 2003, p. 21-32.

PONÇANO, W.L.; CARNEIRO, C.D.R.; ALMEIDA, F.F.M.; PRANDINI, F.L. Mapa Geomorfológico do Estado de São Paulo. São Paulo: IPT, 1981, 94 p.

PRIYA, S. Desktop GIS for Geotechnical Engineering. Journal Environmental Research. vol. 71, no. 2, pp. 75-88, 1995

RAMPAZZO, L. Metodologia científica - para alunos dos cursos de graduação e pós-graduação. Editora Edições Loyolla, 2002.

ROLLEMBERG, 2011

RAY, P. K., KUMRA, V. K. Role of geoinformatics in urban planning. Journal of Scientific Research Banaras Hindu University, Varanasi- Índia. Vol. 55, pp 11-24. 2011

ROLLEMBERG, G. S. T. B. C. ; KAISER, I. M. ; CASTRO, L. I. S. ; RODRIGUES, V. L. ; CURY, A. X. ; RIBEIRO, M. A. ; AZEVEDO, P. F. F. ; DONATO, W. A. . 
Identificação dos pontos de inundação na cidade de Jahu (SP) associados aos períodos de retorno e sua relação com quadro atual de implantação de políticas públicas. $3^{\circ}$ Simpósio de Tecnologia em Meio Ambiente. Fatec-Jahu. JaúSP. 2011.

ROLNIK, R. Planejamento Urbano nos Anos 90: novas perspectivas para velhos temas. In: Luís Ribeiro; Orlando Júnior. (Org.). Globalização, Fragmentação e Reforma Urbana - O futuro das cidades brasileiras na crise. Ed. Civilização Brasileira. Rio de Janeiro, 1994.

RODRIGUES, V. L. Mapeamento geotécnico como base para o planejamento urbano e ambiental: município de Jaú/SP. Dissertação de mestrado. EESC/USP. São Carlos/SP, 2008, 156p.

RUIZ, M.; FORNÉS, A.; RAMON, J.; ALORDA, J.GIS Tools for Landscape Impact Assessment. In: DESIGN AND DECISION SUPPORT SYSTEMS IN URBAN PLANNING. Proceedings of the 6th International Conference, 2002, p.200-209.

SAO PAULO, Plano Estadual de Recursos Hídricos. São Paulo - Conselho Estadual de Recursos Hídricos. Disponível: ftp://ftp.sp.gov.br/ftpcomitepcj/PERH/0407_UGRHI-13.pdf ,2004, Acesso em 07.07.2007.

SILVA, A.B. Sistemas de Informações Geo-referenciadas: Conceitos e fundamentos. Ed. UNICAMP. Campinas/SP, 1999, 240p.

SLAMA, T., TURKI, M. M. Urban planning and management supported by GIS approach case study - EI Kram Municipality, Northern "Grand Tunis", Tunisia. In $1^{\circ}$ International Geomatics Symposium in Saudi Arabi. Jeddah - Arabia Saudita. 2011.

SOARES ET. AL (1980) Soares P.C., Landim P.M.B., Fúlfaro V.J., Sobreiro Neto A.F.. Ensaio de caracterização do Cretáceo no Estado de São Paulo: Grupo Bauru. Rev. Brás. Geociências, 1980.10(3): 177-185.

SOUZA, M. L. Mudar a cidade; uma introdução crítica ao planejamento e à gestão urbana. Rio de Janeiro: Bertrand Brasil, 2002, 560 p.

TAYLOR, N . Urban planning theory since 1945. Editora Sage. Londres. 1998 
TORRES, H. G. Sistemas de Informações Geográficas (SIG) para políticas sociais locais. Workshop: Sistemas de Informação Aplicados às Políticas Públicas Locais: A Perspectiva das Políticas Setoriais. CEBRAP - Centro Estudo das Metrópoles, 2006.

ITS. Programming in Arcview 3.x GIS using Avenue. Guide 94. Informacion Tecnology Service. University of Dorham. Reino Unido. 2007.

VARGAS, M. Técnica, tecnologia e ciência. Revista Eduacação \& Tecnologia. Rio de Janeiro-RJ. 2011.

VAZ, L.F. Classificação genética dos solos e dos horizontes de alteração de rocha em regiões tropicais. Revista Solos e Rochas, São Paulo. 1996. v. 19:2 p. 117-136.

VIEIRA, C. F. C.; PEREIRA, A. M. S.; DIAS, V. M.; CERQUEIRA NETO, J. X.; SILVA, F. R.; FERREIRA, L. A. G. Caracterização geológico - geotécnica das encostas urbanas do município de Salvador. IV COBRAE. Salvador, 2005, CDROM.

VOLPI, E. M. Padrões para aquisição de softwares SIG por administrações públicas municipais. Dissertação de Mestrado, UFSCar, São Carlos/SP, 2006, $119 p$.

YAAKUP, A., LUDIN, A. N. M., SULAIMAN, S., BATURI, H. GIS in urban planning and management: Malaysian experience. In International Symposium \& Exhibition on Geoinformation. PulauPinang - China, 2005.

YUAÇA, F. Tutorial GIS para prefeituras. Apostila de curso. GEOBrasil. 20 de maio de 2003. São Paulo/SP, 2003.

WALSBY, J.; MARCHAND, A.; DACK, S. Information and GIS. Co - operating to manage contaminated land. Proceedings. BRITISH GEOLOGICAL SURVEY. ENVIRONMENT AGENCY,1998.

ZHAO, $\mathrm{H}$. Urban planning management information system based on GIS. In: International Symposium on Web Information Systems and Applications. China. 2009. pp. 076-079.

ZUQUETTE. L.V.; GANDOLFI, N. Cartografia geotécnica. Ed. Oficina de Textos, São Paulo/SP. 2004. 


\section{ANEXO A}

Quadro síntese dos parâmetros e restrições urbanísticas da Lei de Zoneamento 
ANEXO A - Quadro Síntese de parâmetros e restrições urbanisticas de acordo com a Lei de Zoneamento (443/2012)

\begin{tabular}{|c|c|c|c|c|c|c|c|c|c|c|c|c|c|c|c|c|c|c|c|c|c|c|c|c|c|c|c|c|}
\hline \multicolumn{25}{|c|}{$\begin{array}{l}\text { e restriçōes urbanísticas de acordo com a Lei de Zoneamento (443/2012) } \\
E \text { CONSOLDAÇ̊̆O }\end{array}$} & \multirow{3}{*}{$\begin{array}{l}\text { MACROZONA } \\
\text { USOIND.E } \\
\text { LOGiSTICO }\end{array}$} & \multirow{3}{*}{$\begin{array}{c}\text { MACROZONA } \\
\text { USO TURSTIITOO } \\
\text { TIETE }\end{array}$} & \multirow{3}{*}{$\begin{array}{l}\text { MACROZONA } \\
\text { RURAL USO } \\
\text { SUST. }\end{array}$} & \\
\hline \multirow[b]{2}{*}{ ZONEAMENTO } & \multicolumn{9}{|c|}{ ZONAS DE USO } & \multicolumn{15}{|c|}{ ZONAS ESPECIAIS } & & & & \multirow{2}{*}{$\begin{array}{l}\text { MACROZONA } \\
\text { RURALREC. } \\
\text { AMB. }\end{array}$} \\
\hline & ZIND & ZSECOM & ZER 1 & ZER 2 & ZPR 1 & ZPR 2 & ZPR 3 & ZСHAC 1 & ZСНАC 2 & ZEIS 1 & ZEIS 2 & ZEIS 3 & ZEIC 1 & ZEIC 2 & ZEIT 1 & ZEIT 2 & $\mathrm{ZECCH}$ & ZEC PH & ZEPUR & ZERJ & ZECUT & zeau & ZEPN-A & ZEPN-B & & & & \\
\hline Caracteristicas & $\begin{array}{c}\text { Industria, } \\
\text { Comércioe } \\
\text { Servicos de } \\
\text { medio e } \\
\text { grande porte }\end{array}$ & \begin{tabular}{|c|} 
Servicose e \\
Comércio de \\
pequeno e \\
médio porte
\end{tabular} & $\begin{array}{c}\text { Exclusivi. } \\
\text { Residencial de } \\
\text { benixa } \\
\text { densidade, } \\
\text { unifaniliar }\end{array}$ & 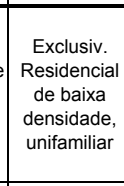 & $\begin{array}{c}\text { Predomm } \\
\text { Residencial }\end{array}$ & 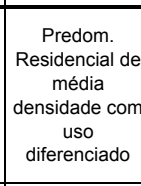 & $\begin{array}{c}\text { Predom. } \\
\text { Residencial } \\
\text { de medial } \\
\text { densidade }\end{array}$ & $\mid \begin{array}{c}\text { Predom. } \\
\text { Residencial } \\
\text { de baxia } \\
\text { densidade }\end{array}$ & 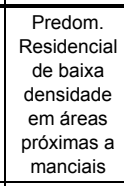 & \begin{tabular}{|c|c|}
$\begin{array}{c}\text { Interesse } \\
\text { Social: } \\
\text { requalificąăo }\end{array}$ \\
\end{tabular} & $\begin{array}{c}\text { Interesse } \\
\text { Sosial } \\
\text { novos projetos }\end{array}$ & $\begin{array}{l}\text { Interesse } \\
\text { Social inovos } \\
\text { projetos }\end{array}$ & \begin{tabular}{|l} 
Interesse \\
Cotural- \\
Museu
\end{tabular} & \begin{tabular}{|l} 
Interesse \\
cultural- \\
Fazenda \\
Maran Luzza
\end{tabular} & 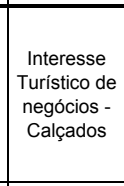 & \begin{tabular}{|l} 
Interesse \\
Turrsiso- \\
upouso \\
Alegre
\end{tabular} & $\begin{array}{c}\text { Centro } \\
\text { Historico: } \\
\text { preservacaio, } \\
\text { comercio e } \\
\text { servicos }\end{array}$ & 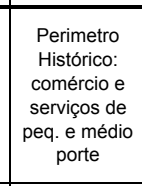 & \begin{tabular}{|l} 
Parcues \\
urtanos
\end{tabular} & $\begin{array}{l}\text { Arreas de } \\
\text { Inluencia } \\
\text { Rio Jaü }\end{array}$ & 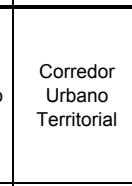 & Anel Urbano & oling & & $\begin{array}{c}\text { Indistria e } \\
\text { seringos de } \\
\text { grande porte }\end{array}$ & \begin{tabular}{|l|l} 
Infra-estrutura \\
tursisice a zarer
\end{tabular} & $\begin{array}{l}\text { uso Rural } \\
\text { Sustentivel }\end{array}$ & 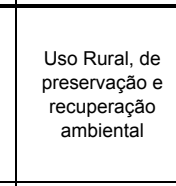 \\
\hline $\begin{array}{c}\text { Uso } \\
\text { Predominante }\end{array}$ & $\mid \begin{array}{c}\text { Und-m } \\
\text { Unld-g } \\
\text { uscm USCg } \\
\text { UIg }\end{array}$ & 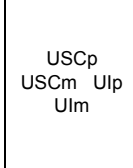 & UR1 Ulp & UR1 UIP & $\begin{array}{l}\text { UR1 UR2 } \\
\text { Uip Uscp }\end{array}$ & ${ }_{\text {UIP } 1 \text { UR2 }}$ & UR1 UIP & \begin{tabular}{|l|l|} 
UR1 UIP \\
\end{tabular} & UR1 UIP & \begin{tabular}{|l} 
UR1 UR2 \\
USCP Ulp
\end{tabular} & $\begin{array}{l}\text { UR1 UR2 } \\
\text { Uscp Ulp }\end{array}$ & 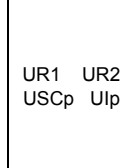 & uc ur & \begin{tabular}{|c|c|c|} 
UR U U \\
URU UTRU
\end{tabular} & ut usc & 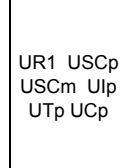 & $\begin{array}{l}\text { UR1 UIp } \\
\text { USCP UTP } \\
\text { UCP }\end{array}$ & 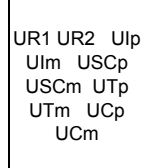 & uL uI & uL uI & 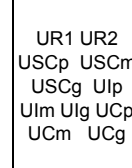 & 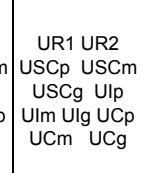 & $\begin{array}{l}\text { Uind } \\
\text { uSC } \\
\text { UI } \\
\text { UC }\end{array}$ & 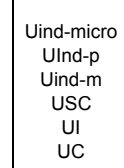 & Und-g Uscg & $\begin{array}{l}\text { UIp UIm UsCp } \\
\text { USCCm URR UL } \\
\text { UCP UCm UTP } \\
\text { UTm }\end{array}$ & URU UTRu UI & URU UTRU U \\
\hline Uso Năo Predominante' & $\begin{array}{l}\text { Uind-micro } \\
\text { UInd-p } \\
\text { USCO UIp } \\
\text { UIm UR2 LU } \\
\text { UT UL }\end{array}$ & 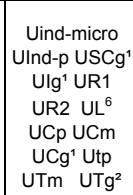 & $u L^{6}$ & $U L^{6}$ & 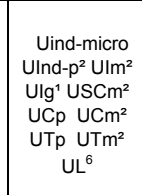 & 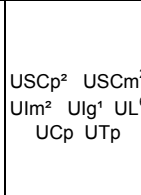 & 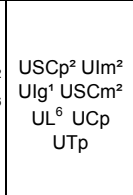 & 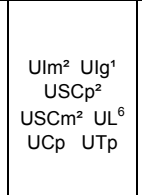 & 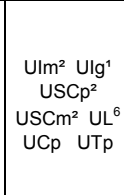 & 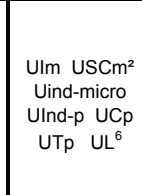 & 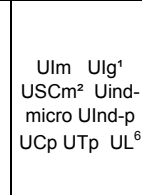 & 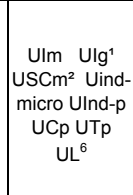 & 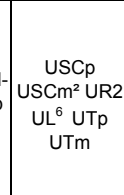 & 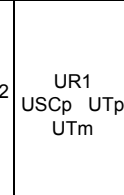 & 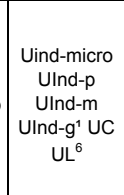 & 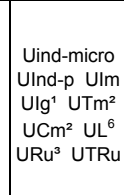 & 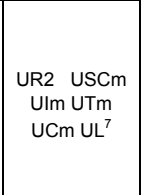 & 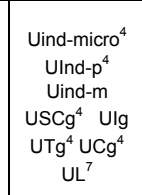 & 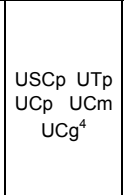 & 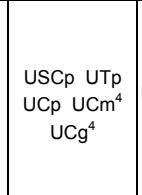 & 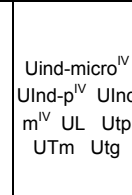 & 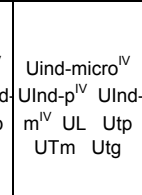 & $\begin{array}{ll}\text { UR1 UR2 } \\
\text { UL Ut } \\
\text { Ut }\end{array}$ & UR1 UR2 & 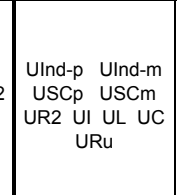 & 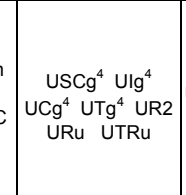 & 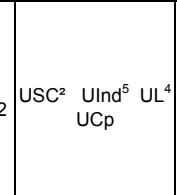 & 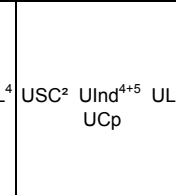 \\
\hline Uso Probibido" & $\begin{array}{l}\text { UR1 } \\
\text { URR } \\
\text { UTRu }\end{array}$ & $\begin{array}{l}\text { Und-m } \\
\text { Unld-g Gu Ru } \\
\text { UTRu }\end{array}$ & $\begin{array}{l}\text { UR2 Ulm² } \\
\text { UII' Und } \\
\text { USC UIUT } \\
\text { URu UTRU }\end{array}$ & 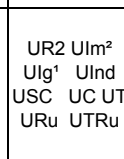 & $\begin{array}{l}\text { Und-m Und-- } \\
\text { g USCg UCg } \\
\text { UTg URu } \\
\text { UTRu }\end{array}$ & 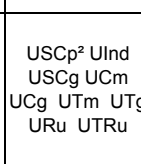 & \begin{tabular}{|l|} 
UR2 Uind \\
USCG UCm \\
UCg UTm \\
UTg URu \\
UTRu
\end{tabular} & \begin{tabular}{|l|} 
UR2 Uind \\
USCg UCm \\
UCg UTTm \\
UTg URu \\
UTRu \\
UTRu
\end{tabular} & 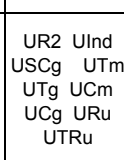 & \begin{tabular}{|c|} 
Uind-m Und-g-g \\
USCg UIg \\
UST UCg \\
UTm UTg \\
URu UTRu
\end{tabular} & $\begin{array}{l}\text { Uind-m Uind- } \\
\text { g USCg UCm } \\
\text { UCg UTm } \\
\text { UT UT URu } \\
\text { UTRu }\end{array}$ & 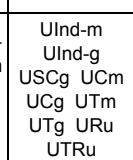 & 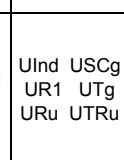 & $\begin{array}{l}\text { Und Uscm } \\
\text { UScS } \\
\text { URT UL } \\
\text { UTg }\end{array}$ & \begin{tabular}{|l|} 
UR1 UR2 \\
URu UTRu
\end{tabular} & 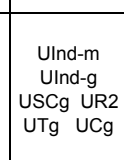 & 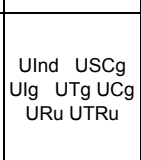 & URu UTRu & 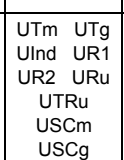 & 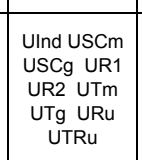 & URU UTRu & $\begin{array}{c}\text { Und-g URu } \\
\text { UTRu }\end{array}$ & \begin{tabular}{l|l}
4 & URU UTRU
\end{tabular} & Und-g URu & UT UR1 UTRU & Und & 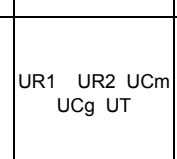 & UR1 UR2 UCm \\
\hline Lote minimo $\left(\mathrm{m}^{2}\right)$ & 600 & 300 & 300 & 500 & 180 & 250 & 300 & 1000 & 2500 & 140 & 160 & 125 & \begin{tabular}{|l|l} 
náa \\
parcelavel
\end{tabular} & \begin{tabular}{|l|l} 
naño \\
parcelivel
\end{tabular} & 1500 & 180 & 180 & 300 & \begin{tabular}{|c|c|} 
nañalo \\
parcelavel
\end{tabular} & $\begin{array}{c}\text { náa } \\
\text { parcelável }\end{array}$ & 300 & 300 & 300 & 300 & 5.000 & 1.000 & 20.000 & 20.000 \\
\hline Testada $(\mathrm{m})$ & 12 & 9 & 12 & 12 & 9 & 10 & 12 & 20 & 40 & 6 & 8 & 5 & N.A. & N.A. & N.A. & N.A. & N.A. & N.A. & N.A. & N.A. & 10 & 10 & 10 & 10 & & & & \\
\hline \multirow{3}{*}{ Recuos w } & Fr $-5,0$ & Fr $-5,0$ & $\mathrm{Fr}-3,0$ & $\mathrm{Fr}-4,0$ & $\mathrm{Fr}_{\mathrm{r}-2,0}$ & $\mathrm{Fr}_{\mathrm{r}-3,0}$ & Fr $-5,0$ & Fr $-5,0$ & Fr - 5,0 & $\mathrm{Fr}-2,0$ & \multirow{3}{*}{$\begin{array}{l}\text { conffome } \\
\text { projeltio }\end{array}$} & \multirow{3}{*}{$\begin{array}{l}\text { confome } \\
\text { projeltio }\end{array}$} & N.A. & N.A. & Fr-10,0 & $\mathrm{Fr}_{\mathrm{r}-2,0}$ & 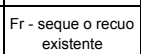 & $\mathrm{Fr}-3,0$ & N.A. & N.A. & Fr $-5,0$ & Fr $-5,0$ & Fr $-5,0$ & Fr $-5,0$ & $\mathrm{Fr}_{\mathrm{r}-10,0}$ & $\mathrm{Fr}_{\mathrm{r}-10,0}$ & & \\
\hline & Fu- 2,0 & Fu- 2,0 & Fu- 2,0 & $F u-2,0$ & Fu- 1,5 & Fu- 2,0 & Fu- 2,0 & Fu- 2,0 & Fu- 10,0 & N.A. & & & N.A. & N.A. & Fu- 5,0 & Fu- 1,5 & Fu- $-1,5$ & Fu- 2,0 & N.A. & N.A. & Fu- 2,0 & Fu- 2,0 & Fu- 2,0 & Fu- 2,0 & $F u-10,0$ & Fu- 5,0 & & \\
\hline & Lat $-2,0$ & Lat $-2,0$ & Lat $-1,5$ & Lat $-2,0$ & $\begin{array}{ll}\text { Lat }-1,5 \\
\end{array}$ & Lat $-1,5$ & Lat $-1,5$ & $\begin{array}{ll}\text { Lat }-2,0 \\
\end{array}$ & Lat 5,5 & Lat $-1,5$ & & & N.A. & N.A. & Lat $-3,0$ & $\begin{array}{ll}\text { Lat }-1,5 \\
\end{array}$ & N.A. & Lat $-1,5$ & N.A. & N.A. & $\begin{array}{ll}\text { Lat }-2,0 \\
\end{array}$ & Lat $-2,0$ & Lat $-2,0$ & $\begin{array}{ll}\text { Lat }-2,0 \\
\end{array}$ & Lat $-5,0$ & Lat $-3,0$ & & \\
\hline Taxa permeabilidade (TP) & 0,2 & 0,15 & 0,2 & 0,2 & $0,1^{1 \mathrm{v}}$ & 0,1 & 0,15 & 0,3 & 0,5 & $0,1^{\mathrm{N}}$ & 0,1 & 0,1 & N.A. & N.A. & 0,2 & 0,1 & 0,1 & 0,1 & N.A. & N.A. & 0,15 & 0,15 & 0,15 & 0,15 & 0,5 & 0,5 & & \\
\hline $\begin{array}{l}\text { Taxa de Ocupação } \\
\text { (TO) }\end{array}$ & 0,8 & 0,8 & 0,7 & 0,7 & $0,8^{\mathrm{N}}$ & 0,8 & 0,8 & 0,6 & 0,4 & 0,9 & 0,9 & 0,9 & N.A. & N.A. & 0,6 & 0,8 & 0,8 & 0,8 & N.A. & N.A. & 0,8 & 0,8 & 0,8 & 0,8 & 0,4 & 0,4 & & \\
\hline $\begin{array}{c}\text { Coeficieinte de } \\
\text { Aproveitamento (CA) }\end{array}$ & 2,0 & 2,0 & 1,5 & 1,5 & 2,0 & 2,0 & 1,5 & 1,5 & 0,4 & 2,0 & 2,0 & 1,0 & N.A. & N.A. & 2,0 & 2,0 & 2,0 & 2,0 & N.A. & 1,0 & $\begin{array}{r}\mathrm{CAB}=3 \\
\mathrm{Cam}=5\end{array}$ & $\begin{array}{c}\mathrm{CAB}=3 \mathrm{Cam} \\
=5\end{array}$ & $\begin{array}{l}\mathrm{CA}=3 \\
\mathrm{Cam}=5\end{array}$ & $\begin{array}{l}\mathrm{CAB}=3 \\
\mathrm{Cam}=5\end{array}$ & 1,0 & 1,0 & & \\
\hline Pavimentos" & 6 pavtos & 6 partos & 2 partos & 2 partos & 4 partos & 4 partos & 2 partos & 3 partos & 2 pavtos & 5 pavtos & 5 pavtos & 2 pavtos & 4 pavtos & 2 partos & 6 pavtos & 4 pavtos & 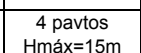 & $\begin{array}{c}\text { 4pavtos } \\
\text { Hmaxis }\end{array}$ & & - & 11 pavtos $^{8}$ & \begin{tabular}{|l|}
1 pavtos $^{8}$ \\
\end{tabular} & \begin{tabular}{|l|}
11 pavtos $^{\circ}$ \\
\end{tabular} & 11 partos $^{\circ}$ & $\mathrm{H}_{\mathrm{mix}}=12 \mathrm{~m}$ & 4 pavtos & & \\
\hline
\end{tabular}

usos:

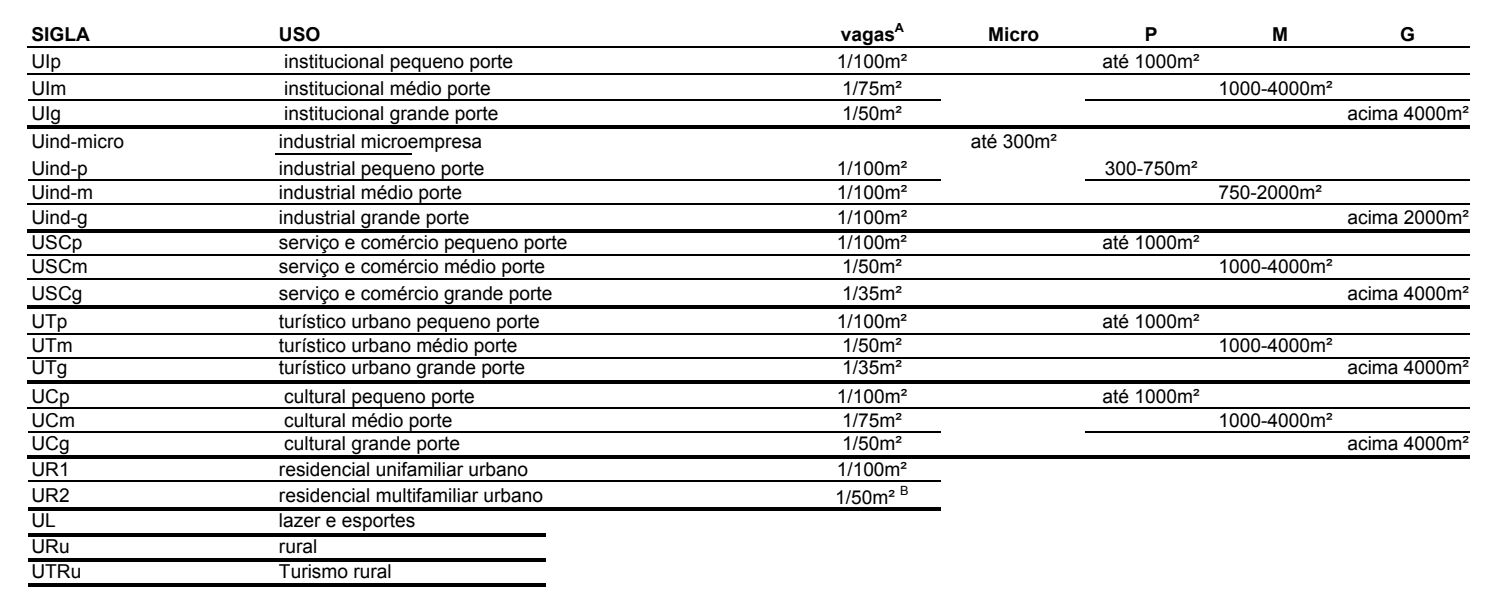

CONDIÇÕES PARA PERMISSÃo DE USO:

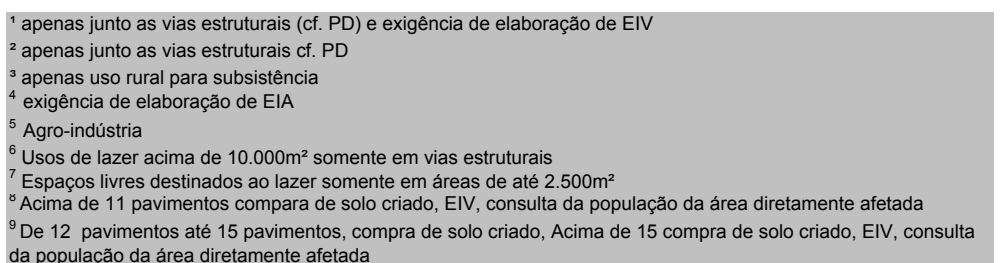

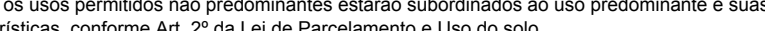

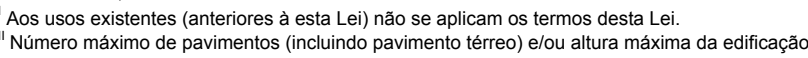
Numero máximo de pavinim
excecăo prevista na lei

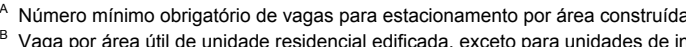

OBSERVAÇOES:

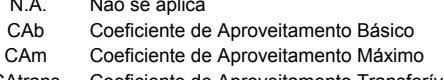

$\begin{array}{ll}\text { CAm } & \text { Coeficieinte de Aprovetitamento Máximo } \\ \text { CAtrans } & \text { Coeficiente de Aprovetitamento Transferive }\end{array}$ 


\section{APÊNDICE A}

SAIIDAS IMPRESSAS DO SISTEMA 


\section{APÊNDICE A.1}

Exemplo de impressão formato A4: Módulo 1 - Uso do Solo 


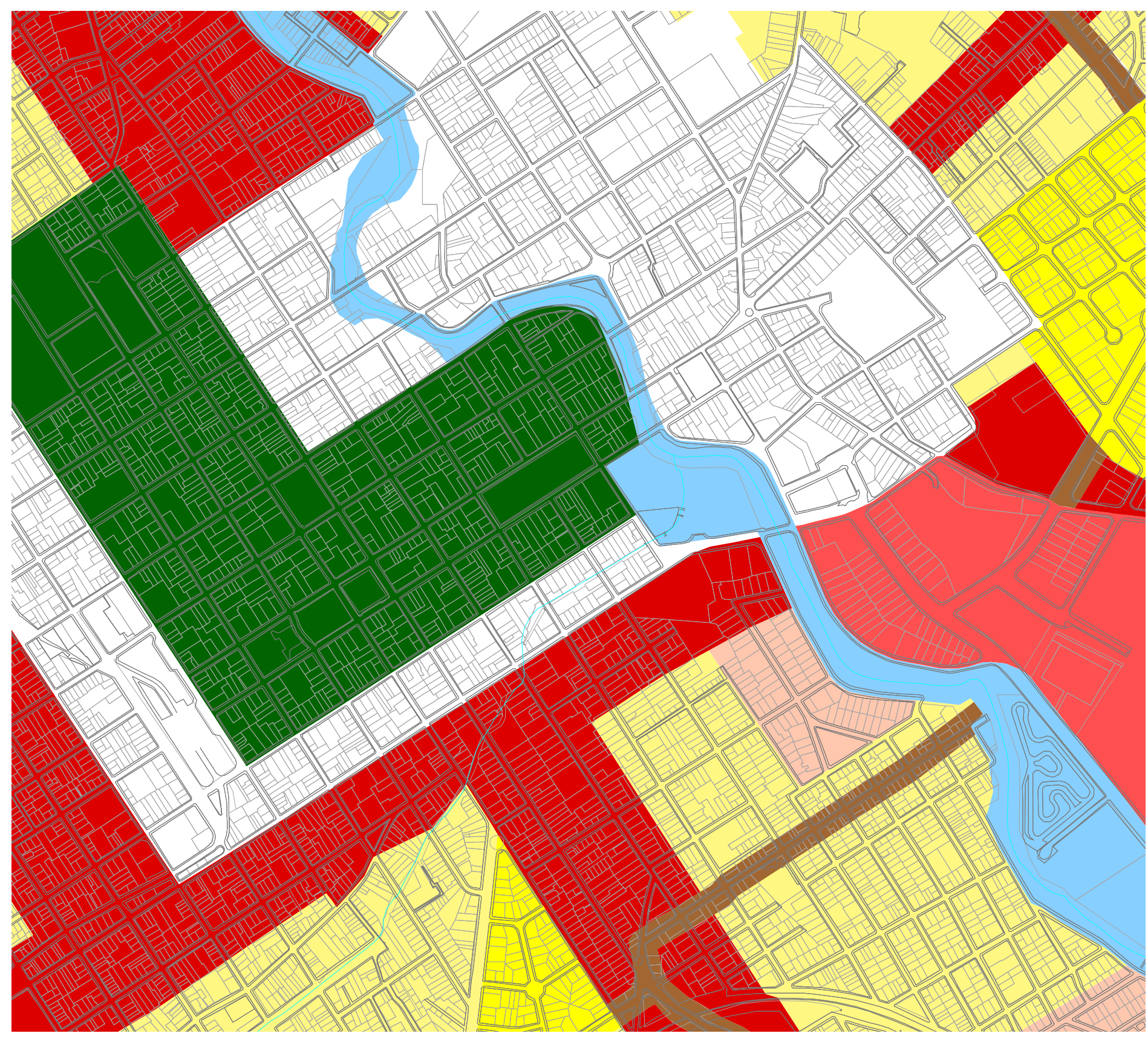

\section{LEGENDA}

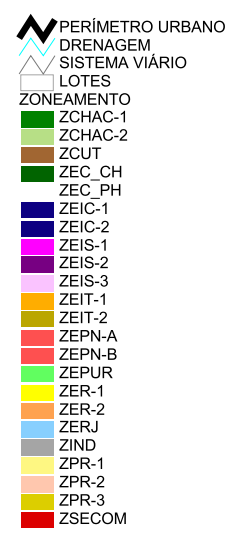

ESCALA $\quad 1: 10000$

$$
\text { S }
$$

SISTEMA DE PROJEÇÃO CARTOGRÁFICA UTM MERIDIANO CENTRAL 510 FUSO 22
Datum Horizontal SAD69 Datum Vertical Imbituba 


\section{APÊNDICE A.2}

Exemplo de impressão formato A1: Módulo 2 - Dados Geotécnicos 

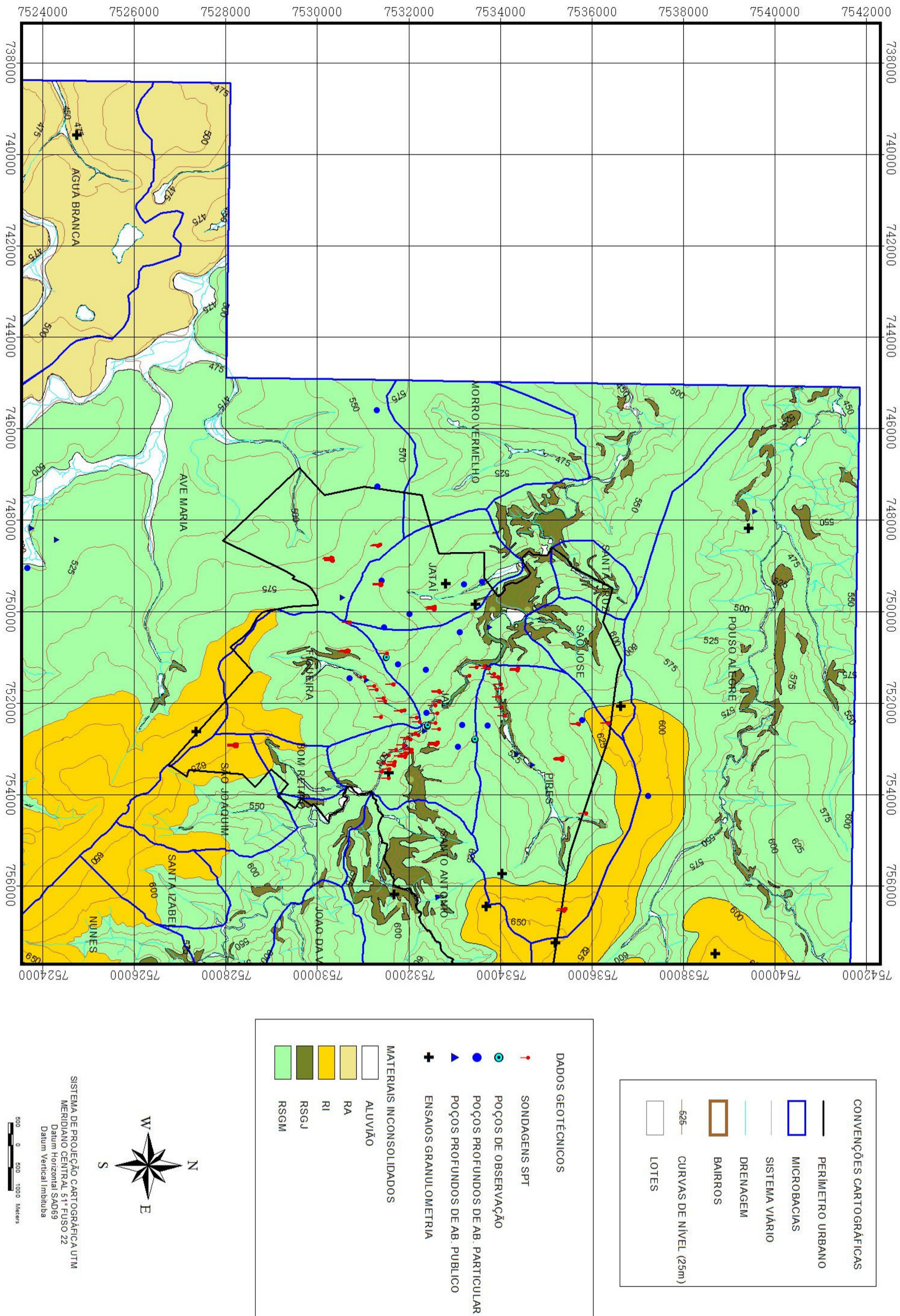